ESTEVAN HELIO PANISELLO CANDEL

\title{
SOLDAGEM DOS AÇOS INOXIDÁVEIS SUPERDUPLEX UNS S32750 E UNS S32760
}

\author{
Dissertação apresentada à Escola Politécnica \\ da Universidade de São Paulo para obtenção \\ do título de Mestre em Engenharia.
}

São Paulo

2016 
ESTEVAN HELIO PANISELLO CANDEL

Engenheiro Mecânico

\section{SOLDAGEM DOS AÇOS INOXIDÁVEIS SUPERDUPLEX UNS S32750 E UNS S32760}

Dissertação apresentada à Escola Politécnica
da Universidade de São Paulo para obtenção
do título de Mestre em Engenharia.

Área de concentração:

Engenharia Metalúrgica e de Materiais

Orientador:

Prof. Dr. Sergio Duarte Brandi

São Paulo

2016 
Este exemplar foi revisado e corrigido em relação à versão original, sob responsabilidade única do autor e com a anuência de seu orientador.

São Paulo, de de

Assinatura do autor:

Assinatura do orientador:

Catalogação-na-publicação

Candel, Estevan Helio Panisello

Soldagem dos aços inoxidáveis superduplex UNS S32750 e UNS

S32760 / E. H. P. Candel -- versão corr. -- São Paulo, 2016.

$137 \mathrm{p}$

Dissertação (Mestrado) - Escola Politécnica da Universidade de São Paulo. Departamento de Engenharia Metalúrgica e de Materiais.

1.Soldagem dos aços inoxidáveis superduplex 2.Processo de soldagem com arame tubular 3.Dutos e tubulações industriais 4.Indústria de óleo e gás 5.Norsok M-601 I.Universidade de São Paulo. Escola Politécnica.

Departamento de Engenharia Metalúrgica e de Materiais II.t. 


\section{AGRADECIMENTOS}

Aos meus filhos pelo apoio e incentivo.

Agradeço ao Prof. Dr. Sérgio Duarte Brandi pela sua inestimável orientação neste trabalho.

A Profa. Dra. Idalina Vieira Aoki pela realização do ensaio SVET e pela colaboração na realização deste trabalho.

Ao Prof. Dr. Paulo Cezar de Souza pela sua colaboração neste trabalho.

Aos colegas do grupo de soldagem da pós-graduação Jaime Casanova Soeiro Junior, Antonio do Nascimento Silva Alves, Rubelmar Maia de Azevedo Cruz Neto, Dario Magno Ferreira Batista, pela colaboração na execução deste trabalho.

Ao Carlos Alberto Faggiani da empresa Lincoln Electric / Metrode Products LTD pela doação dos consumíveis de soldagem e pela soldagem dos corpos de prova.

Ao Rodrigo Signorelli da empresa Outokumpu pela doação dos aços inoxidáveis superduplex utilizados neste trabalho.

Ao Antônio Sérgio Corradini da empresa Proaqt onde foram usinados os corpos de prova e realizados os ensaios destrutivos.

Aos colegas de trabalho pelo apoio.

Finalmente quero agradecer a todos que de alguma forma colaboraram para a realização deste trabalho. 
"Quem teme perder já está vencido" Jigoro Kano 


\section{RESUMO}

O objetivo deste trabalho é viabilizar o uso conjunto, em um mesmo sistema de tubulação, na indústria de óleo e gás, dos aços inoxidáveis superduplex UNS S32750 e UNS S32760. Atualmente as especificações de projeto limitam o uso de um ou outro para um dado sistema, implicando em menor flexibilidade de fornecimento e maiores custos. Adicionalmente será avaliado o processo de soldagem automatizado com arame tubular com matriz metálica (metal cored) e com proteção gasosa. Este processo de soldagem possui grande produtividade e rendimento. Foram estudadas a resistência à corrosão, a resistência mecânica e possíveis danos causados à microestrutura do metal de solda e das zonas afetadas pelo calor (ZAC) dos aços inoxidáveis superduplex UNS S32750 e UNS S32760. A junta foi realizada com chanfro em meio "V", com geometria de $300 \mathrm{~mm}$ por $200 \mathrm{~mm}$ por 6,35 mm e com os seguintes parâmetros de soldagem: tensão de $25 \mathrm{~V}$, corrente de $150 \mathrm{~A}$, velocidade de soldagem de $6,35 \mathrm{~mm} / \mathrm{s}$, velocidade de alimentação do arame de $135 \mathrm{~mm} / \mathrm{s}$ e distância de trabalho de $20 \mathrm{~mm}$. As juntas foram caracterizadas por microscopia óptica, eletrônica de varredura, ensaio de tração, ensaio de dobramento, ensaio Charpy $\mathrm{V} \mathrm{a}-46^{\circ} \mathrm{C}$ e ensaio de corrosão segundo a norma ASTM G48. A base para os critérios de aprovação será o disposto normativo da Norsok Standard M-601, Welding and inspection of piping, na sua mais recente edição (2008). Os resultados mostraram que não existem diferenças significativas entre as soldagens similares e dissimilares com relação às propriedades testadas.

Palavras-chave: Tubulação, Superduplex, Soldabilidade, Arame tubular (MCAW). 


\section{ABSTRACT}

The objective of this work is to enable the use in the same piping system, used in the oil and gas industry, of UNS S32750 and UNS S32760 superduplex stainless steels. Currently, the design specifications limit the use of one or the other for a given system, resulting in less flexibility in supply and higher costs. Additionally, it will be evaluated automated welding process with metal cored using a shielding gas. This welding process has high productivity and efficiency. It was studied corrosion resistance, mechanical strength and possible damage to the weld metal microstructure and heat affected zones (HAZ) of stainless steels superduplex UNS S32750 and UNS S32760. The joint was welded using a half "V" bevel geometry, with $300 \mathrm{~mm}$ by $200 \mathrm{~mm}$ by $6.35 \mathrm{~mm}$ and the following welding parameters: voltage $25 \mathrm{~V}$, current $150 \mathrm{~A}$, welding speed of $6.35 \mathrm{~mm} / \mathrm{s}$, wire feed speed of $135 \mathrm{~mm} / \mathrm{s}$ and $20 \mathrm{~mm}$ working distance. The joints were characterized by optical microscopy, scanning electron microscopy, tensile test, bending test, Charpy $V$ test at $-46{ }^{\circ} \mathrm{C}$ and corrosion test according to ASTM G48. The basis for the criteria for approval is the normative provisions of Norsok Standard M-601, Welding and inspection of piping in its latest edition (2008). The results showed that there are no significant differences between similar and dissimilar welds with respect to the tested properties.

Key words: Pipelines, Superduplex stainless steels, Weldability, Metal Cored Arc Welding (MCAW). 


\section{LISTA DE FIGURAS}

Figura 3.1: Representação das principais conexões do tipo ASME B16.9 utilizadas em sistemas de tubulação para soldagem de topo..........................................................................................26

Figura 3.2: Representação esquemática em corte de chanfro em "V", típico para soldagem de topo em tubos. .26

Figura 3.3: Representação da união de um tubo à uma conexão por meio do processo de soldagem ao arco elétrico com eletrodo revestido (SMAW). .27

Figura 3.4: Representação de um arco elétrico, P1 e P2: potenciais elétricos, B campo eletromagnético. .28

Figura 3.5: Representação do de um ciclo térmico, Tc; temperatura crítica e tc: tempo de permanência na temperatura crítica. .29

Figura 3.6: Representação da repartição térmica, Tp; temperatura de pico, Tf temperatura de fusão, Tc: temperatura crítica, A: zona fundida, B: zona afetada pelo calor e C: metal base. 30

Figura 3.7: Representação dos vários ciclos térmicos, TmA; temperatura de pico no ponto $A, T m B$; temperatura de pico no ponto $B, T m C$; temperatura de pico no ponto $C$

Figura 3.8: Representação do processo de soldagem com arme tubular (FCAW).

Figura 3.9: Representação esquemática do processo de fabricação do arame tubular.

Figura 3.10: Representação esquemática da transferência metálica por curtocircuito. .35

Figura 3.11: Representação esquemática da transferência metálica globular.........36

Figura 3.12: Representação esquemática da transferência metálica por Aerossol..36

Figura 3.13: Microestrutura de um aço inoxidável duplex. A Ferrita é identificada pela parte escura e a Austenita pela parte clara da figura. .44

Figura 3.14: A curva tempo temperatura apresenta a cinética de precipitação das fases secundárias intermetálicas. 
Figura 3.15: Curva tempo de resfriamento para temperatura de $1200{ }^{\circ} \mathrm{C}$ a $800{ }^{\circ} \mathrm{C}$ em função do aporte de calor e da espessura da chapa.

Figura 3.16: Exemplo de trinca na zona afetada pelo calor (ZAC), devido a diferença de espessuras entre o bocal e o casco, de um equipamento em aço inoxidável super duplex

Figura 3.17: Exemplo de falha em uma solda de uma linha em aço inoxidável super duplex devido a desproporção no balanço de fases e na presença de um fluído agressivo.

Figura 3.18: Diagrama de alterações microestruturais na soldagem de Aços Inoxidáveis.

Figura 4.1: Chanfros de acabamento para soldagem dos corpos de prova em aço inoxidável super duplex UNS $\$ 32750$ e UNS $\$ 32760$ .58

Figura 4.2: Esquema dos corpos de prova..... 60

Figura 4.3: Localização dos termopares próximos da abertura. .60

Figura 4.4: Representação do corpo de prova para ensaio de impacto conforme ASTM E23.

Figura 4.5: Parte dos corpos de prova de seção reduzida para o ensaio de impacto conforme ASTM E23.

Figura 4.6: Corpo de prova de seção reduzida para ensaio de tração em chapas conforme ASME IX QW-462.1.

Figura 4.7: Representação esquemática dos equipamentos utilizados para realização do ensaio SVET.

Figura 4.8: Equipamentos utilizados para realização do ensaio SVET, monitor e suporte da sonda (1), porta amostras (2), sonda de calibração (3), suporte do dispositivo ótico (4), mesa suspensa (5) e pré-amplificador (6).

Figura 4.9: Amplificador IPA - 2 Ílon/Polarografic utilizado para realização do ensaio SVET. .70

Figura 5.1: Junta soldada dos corpos de prova aço inoxidável super duplex UNS S32750 e UNS S32760.

Figura 5.2: Ciclos térmicos da soldagem do CP1, UNS S32750, do primeiro passe.

Figura 5.3: Ciclos térmicos da soldagem do CP1, UNS S32750, do segundo passe 
Figura 5.4: Ciclos térmicos da soldagem do CP2, UNS S32760, do passe.

Figura 5.5: Ciclos térmicos da soldagem do CP2, UNS S32760, do segundo passe.

Figura 5.6: Metalografia do aço inoxidável super duplex UNS S32750, a flecha indica o sentido de laminação e a escala apresentada é de $50 \mu \mathrm{m}$.......76

Figura 5.7: Vista frontal com ampliação de 500X do metal de base do UNS $\$ 32750$ com ataque oxálico .76

Figura 5.8: Metalografia do aço inoxidável super duplex UNS S32760, a flecha indica o sentido de laminação e a escala apresentada é de $50 \mu \mathrm{m}$ .77

Figura 5.9: Vista frontal com ampliação de 500X do metal de base do UNS $\$ 32760$ com ataque oxálico. 77

Figura 5.10: Vista frontal com ampliação de 100X do CP1 com ataque oxálico......79

Figura 5.11: Vista frontal com ampliação de 100X do CP2 com ataque oxálico......79

Figura 5.12: Microestrutura, vista superior com aumento de 1.000X, do metal de solda do CP5. .80

Figura 5.13: Microestrutura, vista superior com aumento de 1.000X, do metal de solda do CP6. .80

Figura 5.14: Vista frontal com ampliação de 200X do CP1 com ataque Behara II. 81

Figura 5.15: Vista frontal com ampliação de 200X da ZAC do CP1 com ataque Beharall

Figura 5.16: Vista frontal com ampliação de 200X da ZAC do CP1 com ataque Behara II.

Figura 5.17: Micro inclusão de escória no CP5 e composição química por EDS.....83

Figura 5.18: Micro inclusão de escória associada a carbetos no CP1 e composição química por EDS.

Figura 5.19: Micro inclusão de escória no CP6 primeiro passe e composição química por EDS

Figura 5.20: Micro inclusão de escória no CP6 segundo passe e composição química por EDS. 84

Figura 5.21: Corpo de prova após limpeza e aplicação do líquido penetrante (a), corpo de prova após limpeza e aplicação do revelador (b) 
Figura 5.22: Energias absorvidas no teste de impacto Charpy-V a $-46^{\circ} \mathrm{C}$.

Figura 5.23: Corpo de prova rompido no metal de base.

Figura 5.24: Detalhe da ruptura no metal de base.........................................88

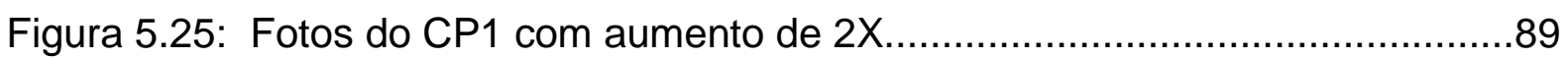

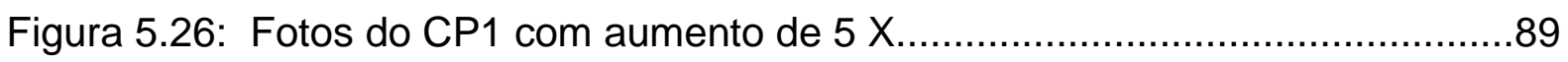

Figura 5.27: Fotos do CP2 com aumento de 2X............................................90

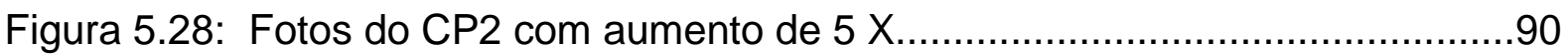

Figura 5.29: Detalhe da parte externa da peça dobrada com a solda ao meio........91

Figura 5.30: Fotos dos CP 1 e CP 4 após o ensaio G-48...................................92

Figura 5.31: Imagem representativa em 2D das densidades das correntes no CP1, UNS S23750, após $2 \mathrm{~h}$ de ensaio .94

Figura 5.32: Imagem representativa em 3D das densidades das correntes no CP1, UNS S23750, após $2 \mathrm{~h}$ de ensaio.

Figura 5.33: Imagem em 2D das densidades das correntes iônicas no CP1 $(A+A+C A)$, após $6 h$ de ensaio .95

Figura 5.34: Imagem em 3D das densidades das correntes iônicas no CP1 $(A+A+C A)$, após $6 h$.

Figura 5.35: Imagem em 2D das densidades das correntes iônicas no CP1 $(A+A+C A)$, após $20 h$ de ensaio ...........................................96

Figura 5.36: Imagem em 3D das densidades das correntes iônicas no CP1 $(A+A+C A)$, após $20 h$ de ensaio 96

Figura 5.37: Imagem em 2D das densidades das correntes iônicas no CP2 $(B+B+C B)$, após $2 h$ de ensaio.

Figura 5.38: Imagem em 3D das densidades das correntes iônicas no CP2 $(B+B+C B)$, após $2 h$ de ensaio.

Figura 5.39: Imagem em 2D das densidades das correntes iônicas no CP2 $(B+B+C B)$, após $6 h$ de ensaio.

Figura 5.40: Imagem em 3D das densidades das correntes iônicas no CP2 $(\mathrm{B}+\mathrm{B}+\mathrm{CB})$, após $6 \mathrm{~h}$ de ensaio 98

Figura 5.41: Imagem em 2D das densidades das correntes iônicas no CP2 $(B+B+C B)$, após 20h de ensaio .99

Figura 5.42: Imagem em 3D das densidades das correntes iônicas no CP2 $(B+B+C B)$, após 20h de ensaio 99 
Figura 5.43: Imagem em 2D das densidades das correntes iônicas no CP5 $(A+B+C A)$, após $2 h$ de ensaio..............................................100

Figura 5.44: Imagem em 3D das densidades das correntes iônicas no CP5 $(A+B+C A)$, após $2 h$ de ensaio.............................................100

Figura 5.45: Imagem em 2D das densidades das correntes iônicas no CP5 $(A+B+C A)$, após $6 h$ de ensaio.................................................101

Figura 5.46: Imagem em 3D das densidades das correntes iônicas no CP5 $(A+B+C A)$, após $6 h$ de ensaio.............................................101

Figura 5.47: Imagem em 2D das densidades das correntes iônicas no CP5 $(A+B+C A)$, após $20 h$ de ensaio............................................102

Figura 5.48: Imagem em 3D das densidades das correntes iônicas no CP5 $(A+B+C A)$, após 20h de ensaio.............................................102

Figura 5.49: Imagem em 2D das densidades das correntes iônicas no CP6 $(A+B+C B)$, após $2 h$ de ensaio................................................103

Figura 5.50: Imagem em 3D das densidades das correntes iônicas no CP6 $(A+B+C B)$, após $2 h$ de ensaio. 103

Figura 5.51: Imagem em 2D das densidades das correntes iônicas no CP6 $(A+B+C B)$, após $6 h$ de ensaio. 104

Figura 5.52: Imagem em 3D das densidades das correntes iônicas no CP6 $(A+B+C B)$, após $6 h$ de ensaio...............................................104

Figura 5.53: Imagem em 2D das densidades das correntes iônicas no CP6 $(A+B+C B)$, após $20 h$ de ensaio 105

Figura 5.54: Imagem em 3D das densidades das correntes iônicas no CP6 $(A+B+C B)$, após $20 h$ de ensaio. 105

Figura 6.1: Metal de solda do CP4 $(A+B+C B)$ com ampliação de 10.000 X........108

Figura 6.2: Metal de solda do CP7 (A+B+CA) com ampliação de 10.000 X........108

Figura 6.3: Resultados individuais do ensaio de impacto Charpy - $\mathrm{V}$ a $-46{ }^{\circ} \mathrm{C}$ na região do metal de solda. .109

Figura 6.4 Imagem representativa da região submetida ao ensaio de impacto para a ZAC

Figura 6.5: Imagem da superfície fratura do CP3 $(A+B+C A)$, com ampliação de $1.000 \times(a)$ e de $5.000 \times(b)$, após o ensaio de tração. 116

Figura 6.6: Imagem da superfície fratura do $C 43(A+B+C B)$, com ampliação de $1.000 \times(a)$ e de $5.000 \times$ (b), após o ensaio de tração 
Figura 6.7: Imagem da superfície fratura do CP5 (A+B+CA), com ampliação de $1.000 \times(a)$ e de $5.000 \times$ (b), após o ensaio de tração.

Figura 6.8: Imagem da superfície fratura do CP6 $(A+B+C B)$, com ampliação de $1.000 \times(a)$ e de $5.000 \times(b)$, após o ensaio de tração.

Figura 6.9: Imagem da superfície fratura do CP7 $(A+B+C A)$, com ampliação de $1.000 \times(a)$ e de $5.000 \times(b)$, após o ensaio de tração. 118

Figura 6.10: Imagem da superfície fratura do CP8 $(A+B+C B)$, com ampliação de $1.000 \times(a)$ e de $5.000 \times(b)$, após o ensaio de tração. 118

Figura 6.11: Imagem em 3D das densidades das correntes iônicas no CP1 $(A+A+C A)$ após $2 h$ de ensaio. 120

Figura 6.12: Imagem em 3D das densidades das correntes iônicas no CP1 $(A+A+C A)$ após $6 h$ de ensaio. 121

Figura 6.13: Imagem em 3D das densidades das correntes iônicas no CP1 $(A+A+C A)$ após $20 \mathrm{~h}$ de ensaio. 121

Figura 6.14: Imagem em 3D das densidades das correntes iônicas no CP2 $(B+B+C B)$ após $2 h$ de ensaio. 122

Figura 6.15: Imagem em 3D das densidades das correntes iônicas no CP2 $(B+B+C B)$ após $6 h$ de ensaio. 122

Figura 6.16: Imagem em 3D das densidades das correntes iônicas no CP2 $(B+B+C B)$ após $20 \mathrm{~h}$ de ensaio. 123

Figura 6.17: Imagem em 3D das densidades das correntes iônicas no CP5 $(A+B+C A)$ após $2 h$ de ensaio. 124

Figura 6.18: Imagem em 3D das densidades das correntes iônicas no CP5 $(A+B+C A)$ após $6 h$ de ensaio. 124

Figura 6.19: Imagem em 3D das densidades das correntes iônicas no CP5 $(A+B+C A)$ após $20 h$ de ensaio. .125

Figura 6.20: Imagem em 3D das densidades das correntes iônicas no CP6 $(A+B+C B)$ após $2 h$ de ensaio. 126

Figura 6.21: Imagem em 3D das densidades das correntes iônicas no CP6 $(A+B+C B)$ após $6 h$ de ensaio. 126

Figura 6.22: Imagem em 3D das densidades das correntes iônicas no CP6 $(A+B+C B)$ após $20 h$ de ensaio. 


\section{LISTA DE TABELAS}

Tabela 3.1: Quadro resumo da composição das principais fases secundárias dos aços inoxidáveis superduplex. . .45

Tabela 4.1: Quadro comparativo das composições químicas dos aços inoxidáveis super duplex UNS S32750 e UNS S32760

Tabela 4.2: Quadro comparativo das propriedades mecânicas dos aços inoxidáveis super duplex UNS S32750 e UNS S32760 conforme recebidos.

Tabela 4.3: Quadro comparativo das composições químicas dos consumíveis de soldagem T2594NLPM2212 e TS2594FM211.

Tabela 5.1: Quadro dos parâmetros de soldagem dos corpos de prova .72

Tabela 5.2: Quadro com valores da taxa de resfriamento entre $1.200{ }^{\circ} \mathrm{C}$ e $800{ }^{\circ} \mathrm{C}$ $\left(\Delta \mathrm{T}_{12-8}\right)$ 74

Tabela 5.3: Medida das lamelas de ferrita e de austenita do UNS S32750 ............75

Tabela 5.4: Medida das lamelas de ferrita e de austenita do UNS S32750............75

Tabela 5.5: Quadro comparativo das composições químicas dos metais das soldas para o UNS S32750 e para o UNS S32760.

Tabela 5.6: Quantitativo da fração volumétrica da ferrita.......................................83

Tabela 5.7: Energias absorvidas no ensaio de impacto Charpy-V a $-46{ }^{\circ} \mathrm{C}$............86

Tabela 5.8: Resultados do ensaio de tração......................................................

Tabela 5.9: Resultados do ensaio de dobramento a $180^{\circ}$ e raio de $12,5 \mathrm{~mm}$.........92

Tabela 5.10: Resultados do ensaio de corrosão....................................................93

Tabela 6.1: Cálculo da variância dos resultados do ensaio Charpy $-\mathrm{V}-46 \stackrel{\circ}{\mathrm{C}}$ dos metais de solda.

Tabela 6.2: Cálculo da variância dos resultados do ensaio Charpy $-\mathrm{V}-46 \stackrel{\circ}{\circ} \mathrm{C}$ das ZAC.

Tabela 6.3: Medição de dureza da ferrita a $8 \mathrm{~mm}$ e $16 \mathrm{~mm}$ da linha da fusão......113

Tabela 6.4: Cálculo da variância das medições de dureza a $8 \mathrm{~mm}$ da linha de fusão

Tabela 6.5: Cálculo da variância das medições de dureza a $16 \mathrm{~mm}$ da linha de fusão 


\section{LISTA DE ABREVIATURAS}

ANSI American National Standard Institute - Instituto de Normas Nacionais Americanas

API American Petroleum Institute - Instituto de Petróleo Americano

ASME American Society of Mechanical Engineers - Sociedade Americana de Engenheiros Mecânicos

ASTM American Society for Testing and Mateirals - Sociedade Americana de Materiais e Testes

AWS Americam Welding Society - Sociedade Americana de Soldagem

CFRP Carbon Fiber Reinforced Plastic - Plástico Reforçado com Fibra de Carbono

$\mathrm{CP} \quad$ Corpo de prova

DRX Difração por raios $X$

EBSD Electron Back Scatter Difraction - Difração por Elétrons Retro Espalhados

EDS Energy Dispersive Spectrometry - Espectrometria por Energia Disperciva

FCAW Flux Cored Arc Welding - Processo de Soldagem com Arame Tubular Auto Protegido

FGRP Fiber Glass Reinforced Plastic - Plástico reforçado com fibra de vidro

FRP Fiber Reinforced Plastic - Plástico reforçado com fibra de vidro

GMAW Gas Metal Arc Welding / Mig/Mag - Processo de Soldagem com Atmosfera Inerte ou Ativa

GTAW Gas Tungsten Arc Welding / TIG - Processo de Soldagem com Eletrodo de Tungstênio

MB Metal de Base

MCAW Metal Cored Arc Welding - Processo de Soldagem com Arame Tubular com Alma Metálica

MEV Microscopia Eletrônica de Varredura

MS Metal de Solda

NACE National Association of Corrosion Engineers - Associação Nacional dos Engenheiros de Corrosão 
NORSOK Norsk Sokkels Konkuranseposisjon - Autoridade Norueguesa de Normas Técnicas

PEAD Polietileno de Alta Densidade

PP Polipropileno

PRE Pitting Resistance Equivalent - Resistência Equivalente à Corrosão Puntiforme ou Alveolar

PVC Cloreto de Polivinil

PVDF Fluoreto de Polivinilideno

S Standard - Padrão

SAW Submerged Arc Welding - Processo de Soldagem ao Arco Submerso

$\mathrm{SCH} \quad$ Schedule - Escala

SLEIS Scanning Localized Electrochemical Impedance Spectroscopy Varredura Localizada da Espectroscopia de Impedância Eletroquímica

SMAW Shielded Metal Arc Welding - Eletrodo Revestido

SVET Scanning Vibrating Eletrode Technique - Técnica de Varredura por Eletrodo Vibrante

XS Extra Strong - Extra Forte

XXS Double Extra Strong - Duplo Extra Forte

ZAC Zona Afetada pelo Calor

ZF Zona Fundida 


\section{SUMÁRIO}

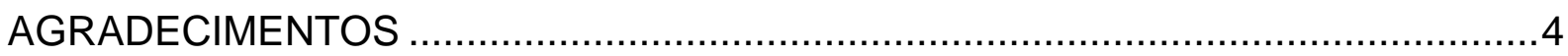

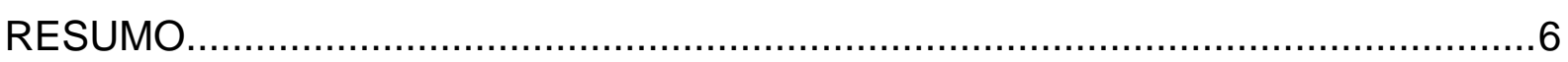

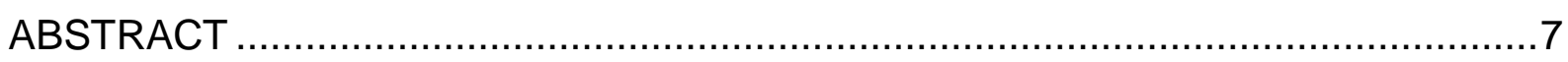

1. INTRODUÇÃO

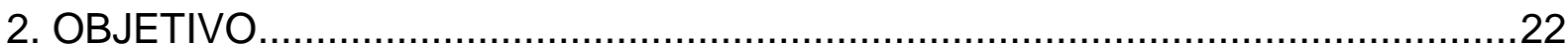

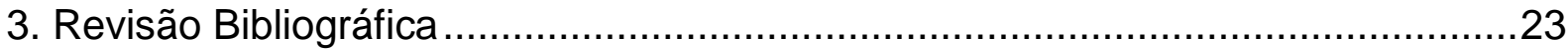

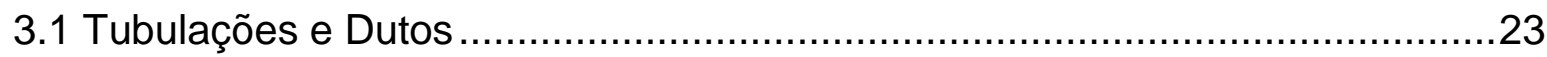

3.1.1 Principais Materiais utilizados na confecção de tubos ........................24

3.1.2 Principais processos de Fabricação de Tubos em Aço ........................25

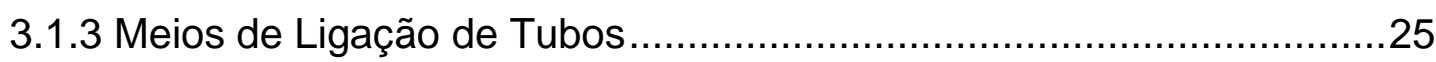

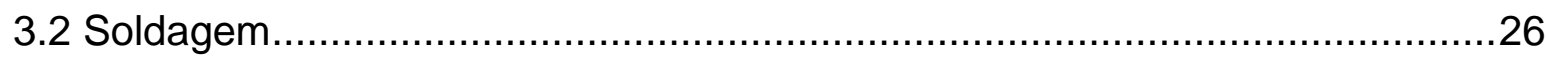

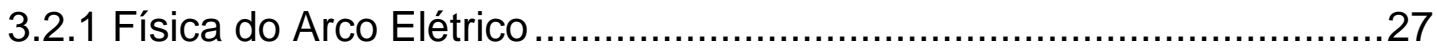

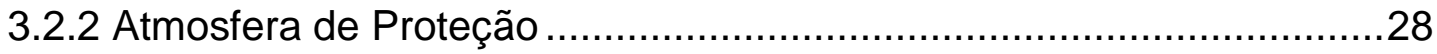

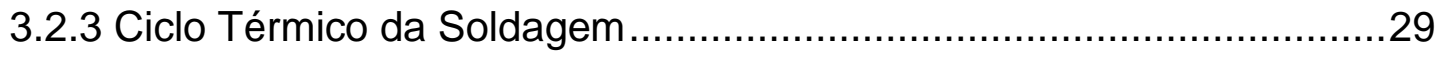

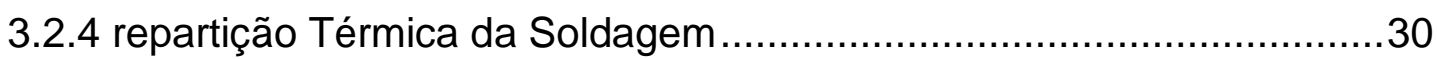

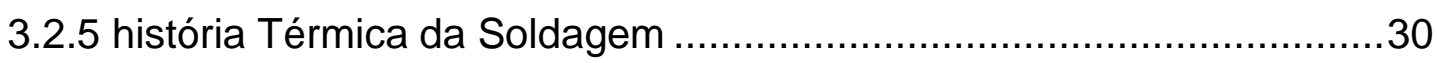

3.2.6 Principais Processos de Soldagem ao Arco Elétrico ............................31

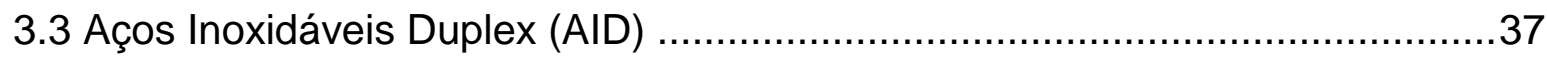

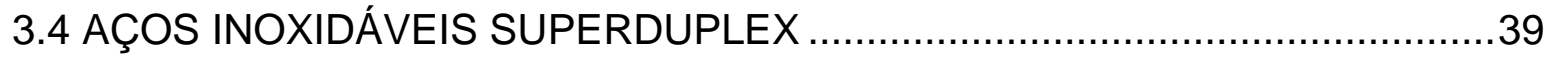

3.4.1 InfluÊncia dos Elementos de liga nos Aços Inoxidáveis Duplex e

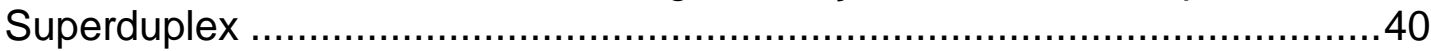

3.4.2 Fases dos Aços Inoxidáveis Duplex e Superduplex ..............................44

3.4.3 Soldabilidade dos Aços Inoxidáveis Duplex ......................................48

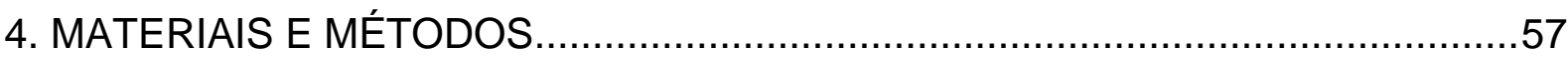



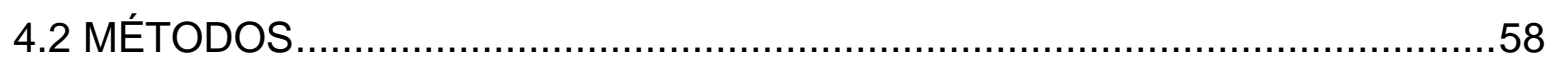



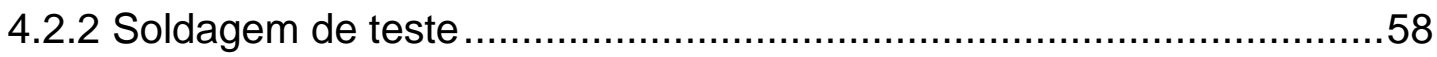

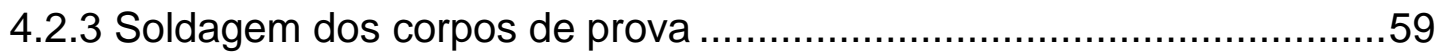

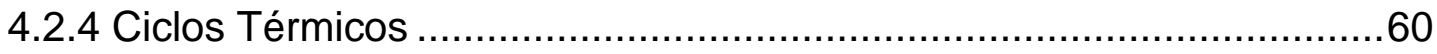

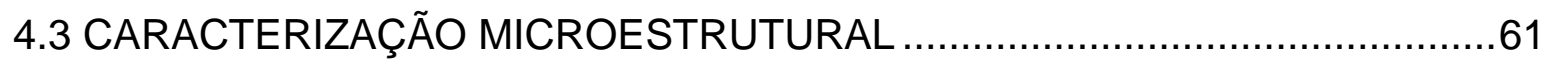

4.3.1 CARACTERIZAÇÃO Microestrutural - Microscopia ótica .....................61

4.3.2 CARACTERIZAÇÃO Microestrutural - Microscopia eletrônica de

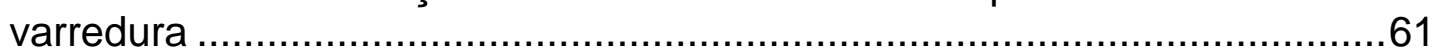

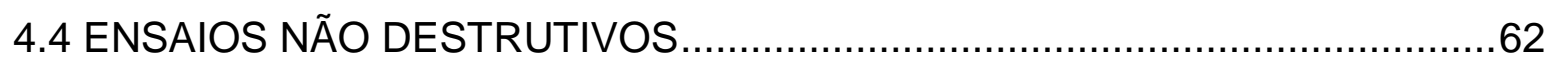

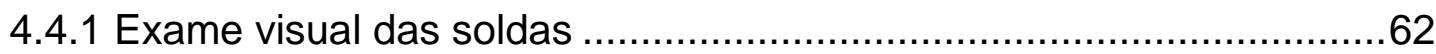




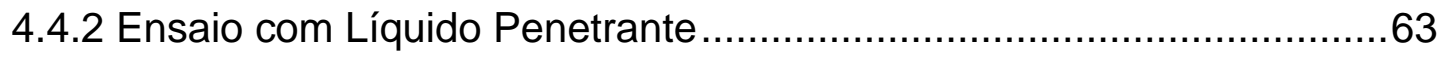

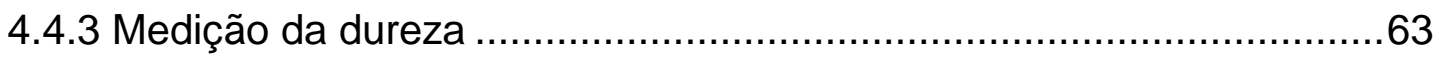

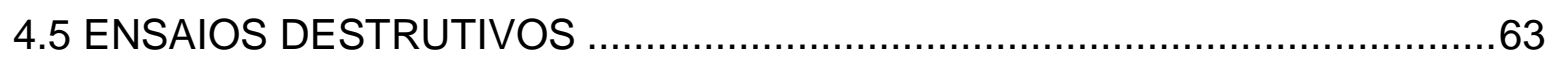

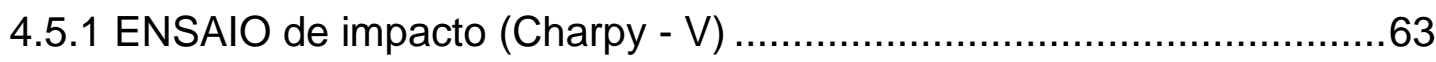

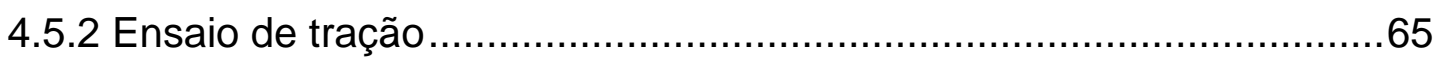

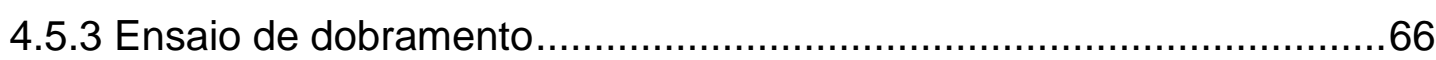

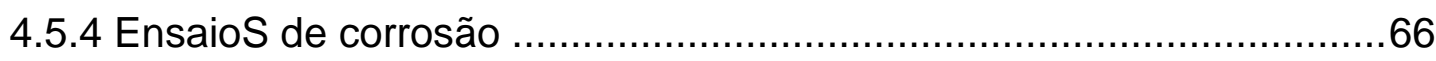

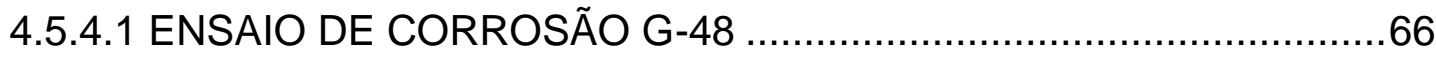

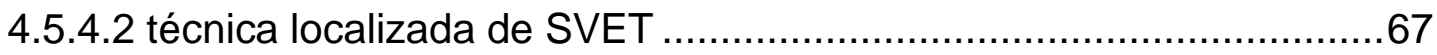

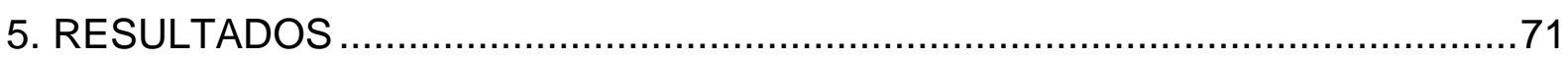

5.1 Soldagem

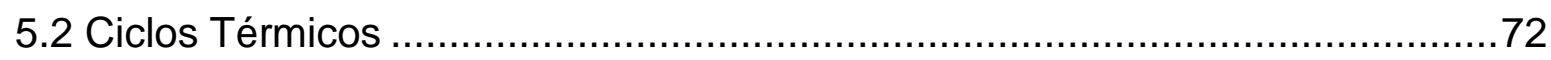

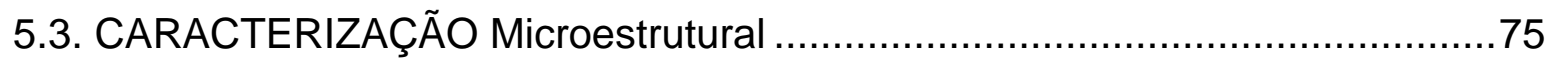

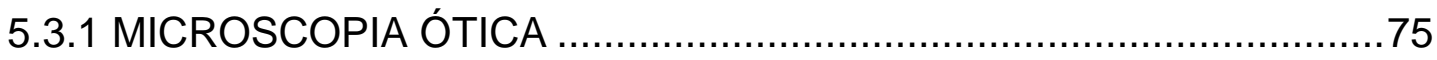

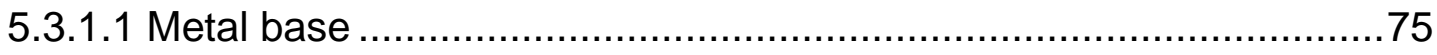

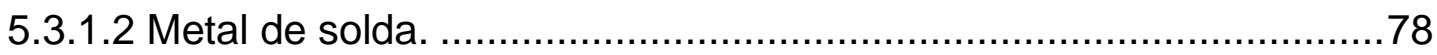

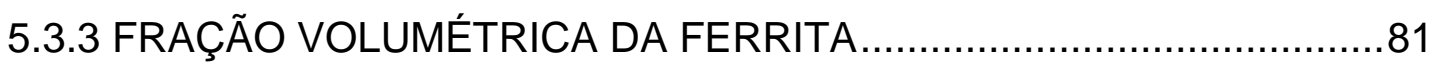

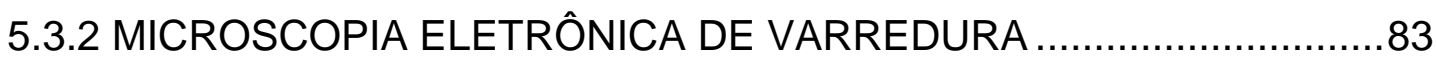

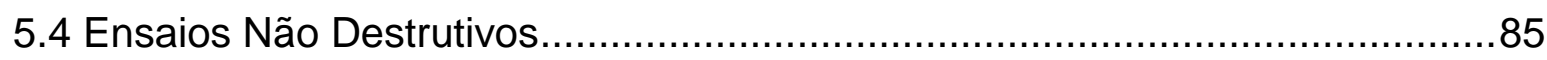

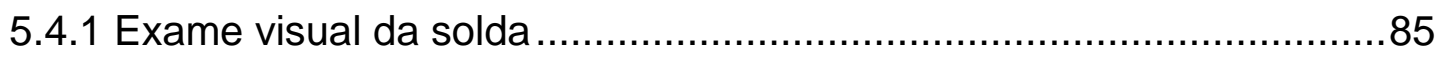

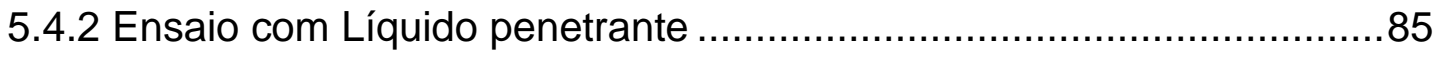

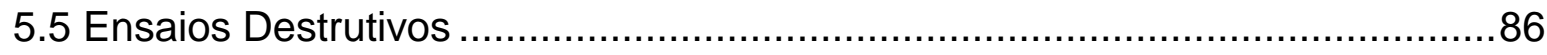

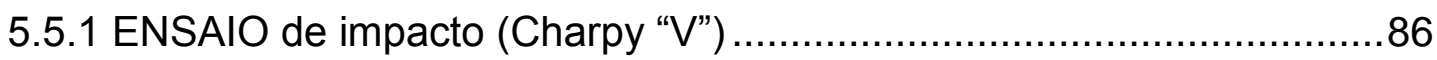



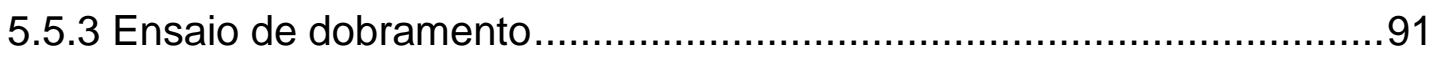



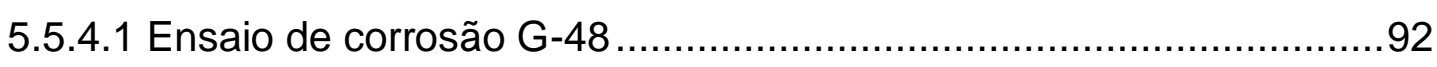

5.5.4.2 técnica localizada de SVET .......................................................93

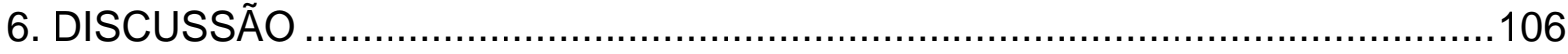

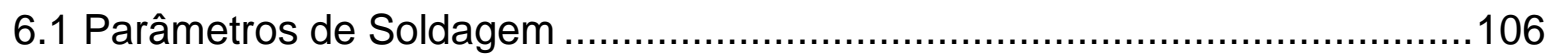

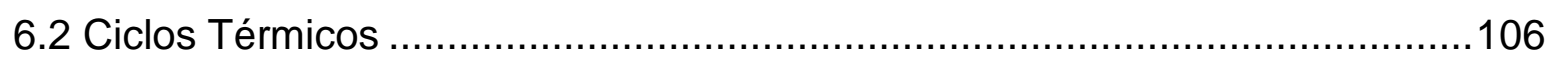

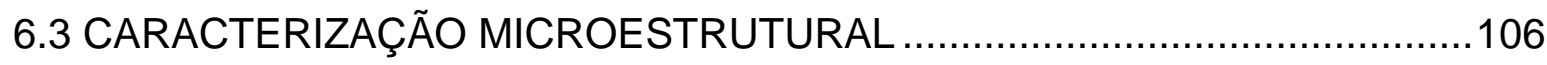



6.3.2 Microscopia ELETRÔNICA DE VARREDURA …...........................107

6.3.3 FRAÇÃO VOLUMÉTRICA DA FERRITA .......................................109

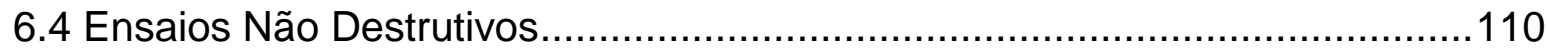

6.5 Ensaios Destrutivos ....................................................................... 


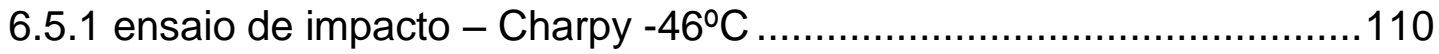

6.5.2 Ensaio de tração conforme ASME IX QW-150 ………..................112

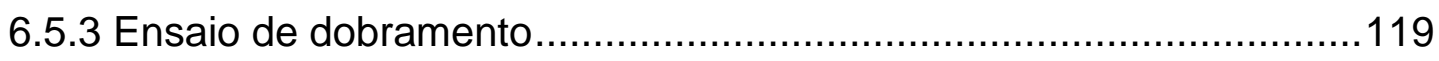

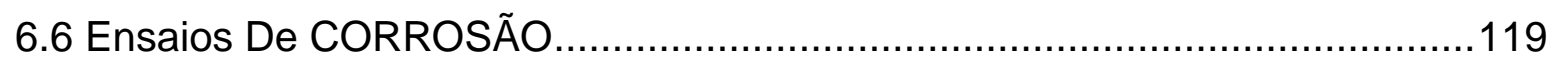

6.6.1 Ensaio de corrosão - G48 …………………..............................119

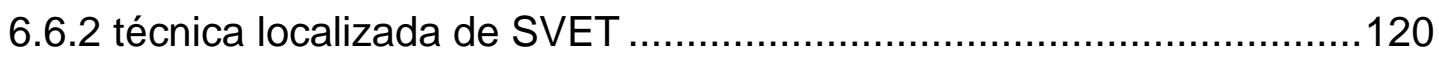

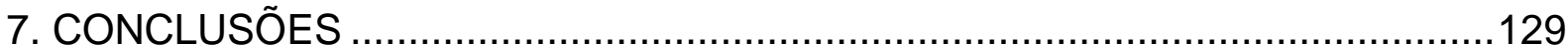

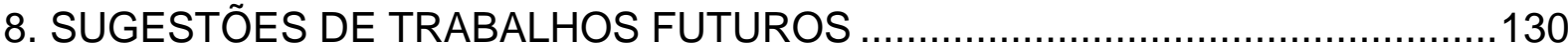

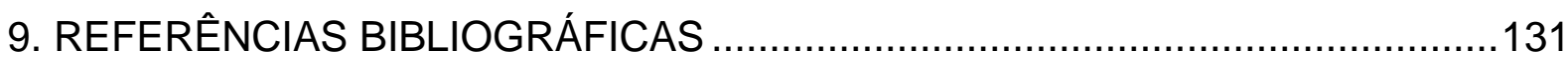




\section{INTRODUCÃ̃O}

Cada vez mais se faz necessária a utilização de materiais especiais para atender às necessidades da indústria do petróleo em face da agressividade dos fluidos provenientes dos campos marítimos recém-descobertos. Neste segmento, os aços inoxidáveis duplex e superduplex vêm sendo empregados como substitutos para vários tipos de aço, uma vez que apresentam maior resistência ao ataque químico, aliado a maior resistência mecânica.

Essas extraordinárias propriedades físicas são alcançadas mediante um rígido controle de sua composição e do balanço da microestrutura com quantidades aproximadamente iguais de ferrita e de austenita, entretanto, estes materiais apresentam dificuldades ao serem trabalhados, principalmente durante o processo de soldagem.

Apesar destas vantagens, a soldagem destes aços não é trivial, parâmetros de soldagem mal definidos e/ou velocidade de resfriamento da poça de fusão inadequada podem levar à precipitação de nitretos e/ou carbonetos, formação de fases secundárias indesejáveis, tamanho de grão elevado, bem como comprometimento do balanço da microestrutura, fatores que podem fragilizar e também comprometer a resistência à corrosão dos aços inoxidáveis duplex e superduplex.

Acrescenta-se a isto o fato da indústria nacional ter pouca experiência na utilização destes materiais na fabricação de equipamentos e na confecção de sistemas de tubulações de processo, e os resultados são elevados custos de implantação de novas unidades e enormes prejuízos por perdas de produção decorrentes de falhas causadas por trabalhos mal executados.

No segmento dos aços inoxidáveis superduplex existem dois tipos amplamente usados na confecção de vasos de pressão e de sistemas de tubulação, o UNS S32750 e o UNS S32760, cujas composições químicas são muito parecidas, porém, o UNS S32760 contém Cu e W que não estão presentes no UNS S32750. 
Esses materiais não são utilizados conjuntamente, o UNS S32750 vem sendo utilizado apenas para reparos em unidades existentes, cuja construção de alguns equipamentos ou sistemas de tubulação tenha sido feitos com este material, sendo que para novas unidades recomenda-se a utilização apenas do UNS S32760.

Face à grande quantidade de unidades de produção em carteira de projeto para os próximos anos, preocupa o risco e a complexidade no tocante à suprimentos, visto que fornecedores já acenaram com a possibilidade de não poderem atender a demanda para esses novos projetos em andamento, que pela atual filosofia devem ser executadas apenas com o UNS S32760.

A desmistificação da soldagem entre estes dois tipos de aços inoxidáveis superduplex poderá reverter a atual filosofia de projeto, possibilitando a utilização de qualquer destes dois tipos de material, conforme a disponibilidade do mercado. 


\section{OBJETIVO}

O objetivo deste trabalho é avaliar as alterações de resistência mecânica e de resistência à corrosão, bem como as alterações microestruturais dos aços inoxidáveis superduplex UNS S32750 e UNS S32760, quando unidos por meio de soldagem autógena, similar ou dissimilar, para aplicações na indústria de petróleo e gás natural. A base para as avaliações será a norma Norsok M-601 ed. 2008, referência para projeto, manutenção e operação de unidades marítimas de produção de petróleo e gás natural, e o processo de soldagem utilizado será o arame tubular com alma metálica, também conhecido por Metal Cored Arc Welding (MCAW), automatizado. 


\section{REVISÃO BIBLIOGRÁFICA}

\subsection{TUBULAÇÕES E DUTOS}

Denominamos tubulações e dutos, sistemas compostos por tubos, conexões, válvulas, acessórios e instrumentos cuja finalidade é conduzir fluidos, de forma forçada, através de um conduto. Desta forma transportando produtos e energia de um ponto a outro ${ }^{(39)}$.

Aparentemente os dois sistemas são iguais, mas há uma grande diferença entre eles. Os sistemas de tubulações transportam fluidos dentro de uma unidade industrial, intramuros de uma única personalidade jurídica. Fisicamente são caracterizados por diâmetros menores, espessuras de parede menores, poucos trechos retos, inúmeras conexões, válvulas, acessórias e instrumentos. Já os sistemas de dutos transportam fluidos ligando unidades distintas, extramuros de personalidades jurídicas diversas. Fisicamente são caracterizados por grandes diâmetros, espessuras de parede maiores, longos trechos retos poucas conexões, válvulas, acessórios e instrumentos ${ }^{(39)}$.

Em face da principal característica dos dutos, que são os longos trechos retos, os tubos para sua confecção são fornecidos com o comprimento de 12 metros, já os tubos utilizados em sistemas de tubulação são fornecidos com o comprimento de 6 metros. Sua fabricação deve atender a critérios estabelecidos em normativas técnicas, desta forma fazendo com que tubos confeccionados por fabricantes diferentes possam ser utilizados conjuntamente em um mesmo sistema. No setor petroquímico as normas mais utilizadas são as da American Society of Mechanical Engineers (ASME) e American Society for Testing and Materials (ASTM) ${ }^{(39)}$.

Para um mesmo diâmetro de tubos podemos ter inúmeras espessuras diferentes e padronizadas por uma escala, que em Inglês chamamos de Schedule e abreviada por $\mathrm{SCH}$. Inicialmente havia apenas três tipos de escala $(\mathrm{SCH})$ a $\mathrm{S}$, a XS e a XXS que representavam a resistência do tubo, respectivamente, standard (Padrão), 'extra strong' (Extra Forte) e 'double extra strong' (Duplo Extra Forte). Outro fato relevante 
diz respeito às dimensões externas do tubo, onde o diâmetro externo difere do nominal até o diâmetro de 12 polegadas. Somente a partir do diâmetro de 14 polegadas é que o diâmetro externo coincide com o nominal, ficando desta maneira para tubos de até 12 polegadas SCH S (Standard) o diâmetro interno aproximadamente igual ao nominal. Desta forma ao especificar um tubo informa-se o diâmetro nominal em polegadas e a escala, exemplo tubo de 4" SCH S, cujo diâmetro interno é de 102,3 mm e a espessura de $6 \mathrm{~mm}$, ou tubo de 10" SCH S, cujo diâmetro interno é de $254,5 \mathrm{~mm}$ e a espessura de $9,3 \mathrm{~mm}$ e assim por diante ${ }^{(39)}$.

Com o aprimoramento da metodologia de cálculo constatou-se que para muitas aplicações, dependendo do diâmetro, o tubo acabava por ficar superdimensionado e, de acordo com o desenvolvimento dos processos de fabricação de tubos e conexões, inúmeras espessuras foram incorporadas e padronizadas pela norma ASME B 36.10, que define padrões de fabricação para tubos de aço carbono e ASME B 36.19, que define padrões de fabricação para tubos de aço inoxidáveis ${ }^{(39)}$.

\subsubsection{PRINCIPAIS MATERIAIS UTILIZADOS NA CONFECÇÃO DE TUBOS}

Basicamente os materiais utilizados na fabricação de tubos podem ser divididos em dois tipos: materiais não metálicos e materiais metálicos que igualmente podem ser divididos em outros dois tipos diferentes: os materiais metálicos ferrosos e os materiais metálicos não ferrosos ${ }^{(39)}$.

Os principais materiais metálicos ferrosos utilizados na fabricação de tubos são os aços carbono, aços liga, aços inoxidáveis, como os aços inoxidáveis duplex, os ferro fundidos, os aços forjados e suas variações. $\mathrm{Na}$ fabricação de tubos metálicos não ferrosos são utilizados o cobre, cobre-níquel, bronze, latão, titânio, zircônio, níquel e suas ligas, como o monel, e o chumbo. $O$ chumbo $(\mathrm{Pb})$ que também é chamado de Plumb ou Plumbo em algumas línguas teve uma importância tão grande na antiguidade e foi tão amplamente utilizado na confecção de sistemas de água e esgoto que nos países de língua inglesa, apesar da utilização do termo piping (tubulação), até os dias de hoje utiliza-se o termo Plumbing para descrever sistemas de encanamento e Plumber para identificar o profissional encanador ${ }^{(39)}$. 
Os materiais não metálicos mais comumente utilizados são os poliméricos (plásticos e elastômeros) tais como: borrachas, cloreto de polivinil (PVC), polietileno de alta densidade (PEAD), polipropileno (PP), fluoreto de polivinilideno (PVDF), poliéster, acrílicos, epóxi, fenólicos, os plásticos reforçados com fibra de vidro (FRP ou FGRP), e também os plásticos reforçados com fibra de carbono (CFRP). Fora do âmbito dos poliméricos cita-se o concreto, cerâmica, cimento amianto e o vidro dentre tantos outros que compõem a lista dos demais materiais não metálicos ${ }^{(39)}$.

\subsubsection{PRINCIPAIS PROCESSOS DE FABRICAÇÃO DE TUBOS EM AÇO}

Os tubos em aço podem ser confeccionados por meio de extrusão, processo utilizado para pequenos diâmetros e por meio de laminação, processo utilizado para tubos de até 12 polegadas. Estes dois processos permitem que os tubos sejam ofertados sem costura, sem emendas. Outro processo de fabricação de tubos, usado para tubos de grande diâmetro, consiste em calandrar uma chapa e unir seus lados formando um tubo, a união é soldada e esta solda pode ser longitudinal ou helicoidal, estes tubos recebem a denominação de tubos com costura ${ }^{(39)}$.

\subsubsection{MEIOS DE LIGAÇÃO DE TUBOS}

Na confecção de sistemas de tubulação se faz necessária à ligação entre tubos e entre os tubos e conexões, essas ligações podem ser rosqueadas, flangeadas, união do tipo ponta e bolsa, união por compressão e uniões soldadas, do tipo encaixe e solda ou do tipo solda de topo, figura 3.1, sendo este o tipo mais utilizado para sistemas de tubulação para hidrocarbonetos. Para a soldagem de topo se faz necessária à utilização de chanfro nas extremidades dos tubos e conexões, figura $3.2^{(39)}$. 


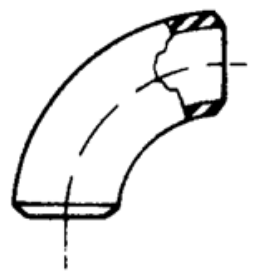

JOELHO 90"

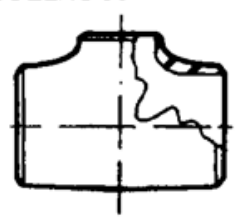

TÊ DE REDUÇÃO

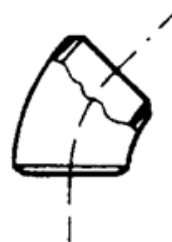

JOELHO $45^{\circ}$

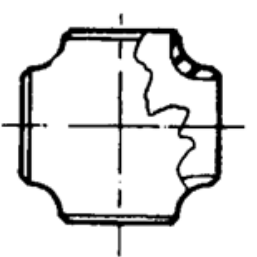

CRUZETA

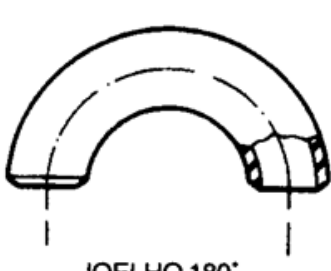

JOELHO $180^{\circ}$

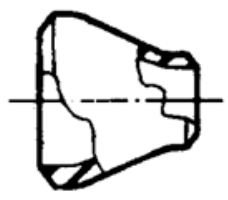

REDUÇÃO CONCÊNTRICA

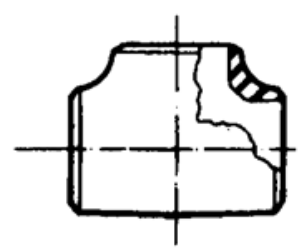

TÊ

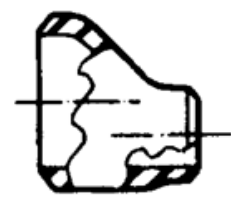

REDUÇÃO EXCENTRICA

Figura 3.1: Representação das principais conexões do tipo ASME B16.9 utilizadas em sistemas de tubulação para soldagem de topo. (Telles, 1987)

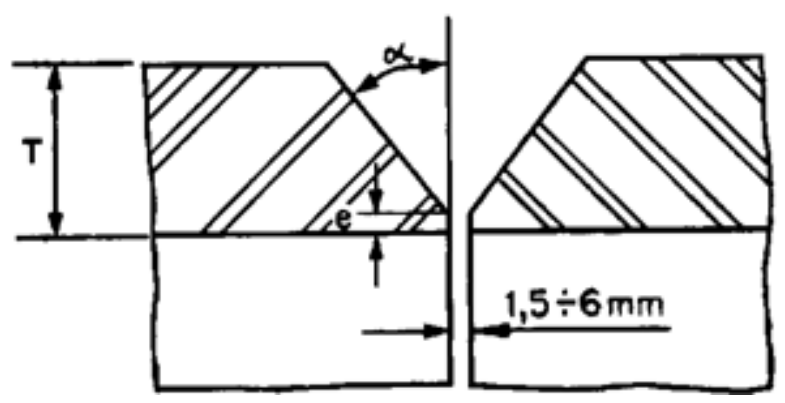

Figura 3.2: Representação esquemática em corte de chanfro em "V", típico para soldagem de topo em tubos. (Telles, 1987)

\subsection{SOLDAGEM}

A soldagem, no caso particular dos aços, é um processo de união de materiais pela fusão, consequência do aquecimento proveniente de uma fonte de calor, e posterior solidificação das partes fundidas. O calor pode ser proveniente de uma fonte externa ou também obtido pelo atrito entre as partes a serem unidas ${ }^{(3)}$. 
A fonte de calor mais comumente utilizada nos processos de soldagem dos aços é o arco elétrico, figura 3.3, a primeira patente de soldagem ao arco elétrico que se tem conhecimento foi obtida na Inglaterra em 1865 por Wild após conseguir, por meio de uma corrente elétrica, fundir duas peças de ferro. Após essa descoberta inúmeros experimentos foram realizados em diversas partes do mundo até a obtenção do eletrodo consumível, que além de ser utilizado na geração do arco elétrico também tinha a função de metal de adição. Porém, por falta de atmosfera de proteção, esse processo estava exposto ao ar atmosférico, o que resultava em baixa qualidade das soldas devido ao oxigênio e ao nitrogênio. Somente no início dos anos 1900 descobriu-se a importância de uma atmosfera de proteção para evitar a formação de óxidos e nitretos no metal de solda, e também para estabilizar o arco elétrico, e em 1907 foi patenteado o primeiro eletrodo revestido desenvolvido por Oscar Kjellberg na Suécia ${ }^{(3)}$.

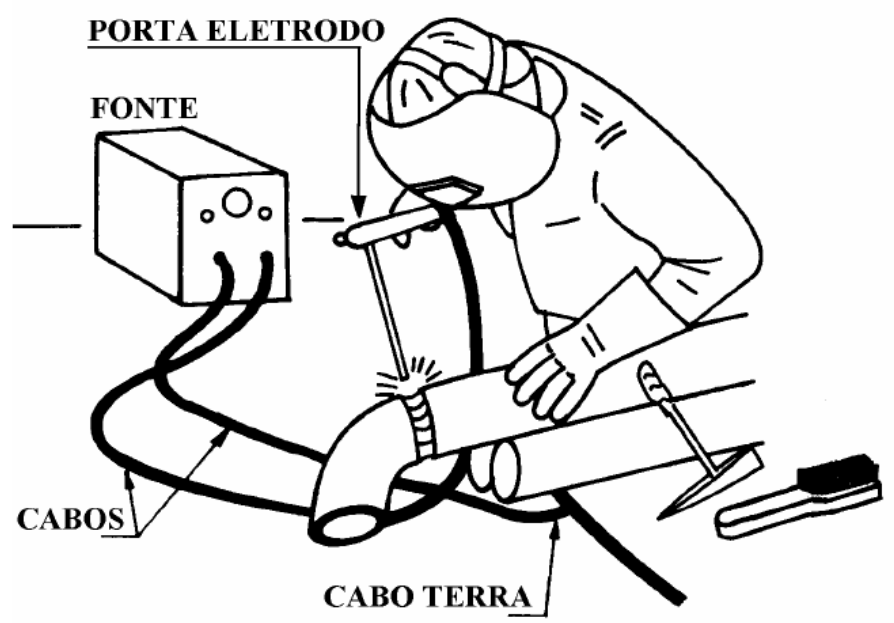

Figura 3.3: Representação da união de um tubo a uma conexão por meio do processo de soldagem ao arco elétrico com eletrodo revestido (SMAW) ${ }^{(40)}$.

\subsubsection{FÍSICA DO ARCO ELÉTRICO}

Conforme mencionado o arco elétrico é a fonte de calor mais utilizada na soldagem dos aços devido a sua elevada potência, excelente controlabilidade e baixo custo. $\mathrm{O}$ arco elétrico basicamente é uma descarga elétrica através de um gás iônico, iniciada por uma quantidade de elétrons emitidos a partir do eletrodo e mantida pela ionização do gás aquecido gerando uma temperatura suficiente para fundir os 
materiais a serem unidos. Essa descarga, corrente elétrica, é função direta da diferença de potencial elétrico entre o eletrodo e a peça e também da distancia entre eles, esse processo é altamente eficiente, pois a quase totalidade da energia elétrica é transformada em calor ${ }^{(3)}$.

O arco elétrico gera uma coluna de plasma, que devido a trajetória axial do arco dentro de uma atmosfera controlada e a diferença entre as dimensões do eletrodo e da peça, assume a forma de um cone, figura 3.4. As extremidades do cone são regiões de queda de tensão anódica e catódica que variam com o comprimento do arco, a intensidade da corrente elétrica e com a atmosfera de proteção. A qualidade do processo de soldagem está diretamente associada a qualidade do arco elétrico, que por sua vez depende da criação de íons e elétrons livres responsáveis pelo transporte da corrente elétrica ${ }^{(3)}$.

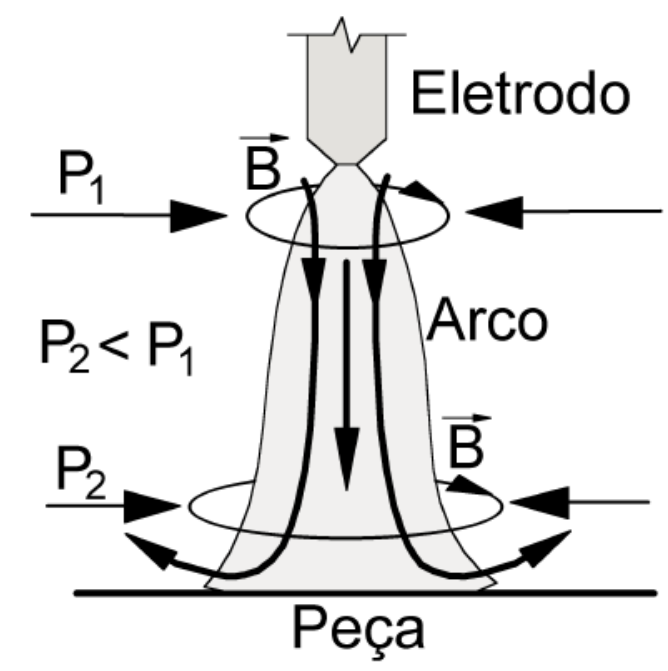

Figura 3.4: Representação de um arco elétrico, P1 e P2: potenciais elétricos, B campo eletromagnético ${ }^{(40)}$.

\subsubsection{ATMOSFERA DE PROTEÇÃO}

Somente na segunda metade da década de 1910 é que se descobriu a necessidade de uma atmosfera de proteção para isolar o metal fundido do ar atmosférico e evitar danos ao metal de solda. Posteriormente a proteção gasosa foi utilizada não somente com o intuito de isolar o metal fundido, mas também com uma forma de 
acrescentar elementos de liga ao metal de solda, alterando significativamente as propriedades mecânicas da solda. A atmosfera de proteção pode ser ativa, quando reage quimicamente com o metal fundido ou passiva quando não reage com o metal fundido ${ }^{(3)}$.

$\mathrm{Na}$ soldagem de tubos de materiais especiais como os aços inoxidáveis e os aços inoxidáveis duplex além da atmosfera de proteção acima descrita é usual a purga dos tubos, o que se consegue quando a atmosfera no interior dos tubos é controlada para evitar a oxidação do metal fundido durante a soldagem do primeiro passe, que denominamos de raiz da solda, ou na soldagem de passe único ${ }^{(3)}$.

\subsubsection{CICLO TÉRMICO DA SOLDAGEM}

Uma das principais características dos processos de soldagem é a de aquecer rapidamente uma pequena quantidade de material até que atinja sua temperatura de fusão de forma controlada de maneira que possa se solidificar em seguida, unindo duas peças ou simplesmente fazendo o preenchimento de uma determinada região, e isso só é possível através do controle do calor fornecido à peça. A variação de temperatura em função do tempo em uma dada distância do centro da solda é denominada de Ciclo Térmico da Soldagem, função direta dos parâmetros de soldagem, do processo de soldagem, das propriedades físicas dos materiais e da geometria da junta a ser soldada, figura $3.5^{(3)}$.

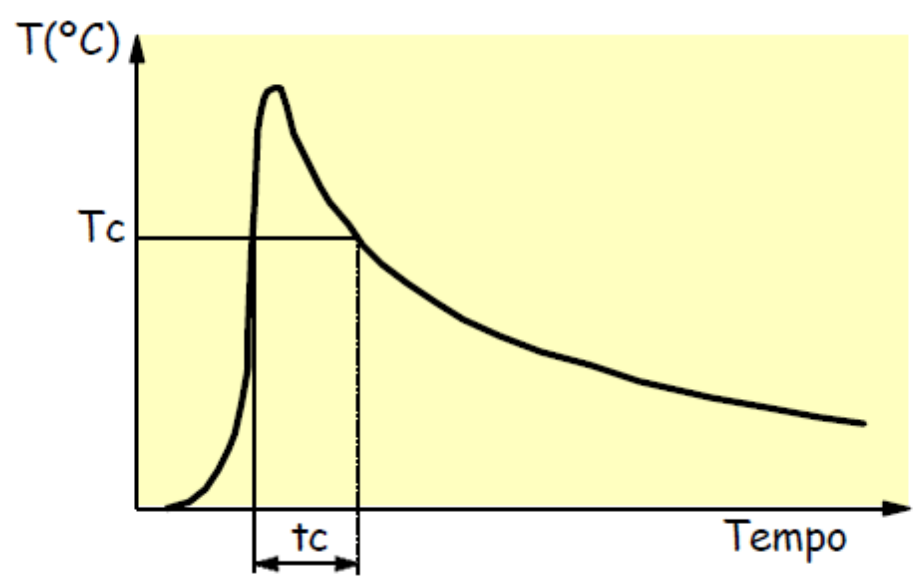

Figura 3.5: Representação do de um ciclo térmico, Tc; temperatura crítica e tc: tempo de permanência na temperatura crítica ${ }^{(40)}$. 


\subsubsection{REPARTIÇÃO TÉRMICA DA SOLDAGEM}

Outro ponto importante é a Repartição Térmica que é a varrição da temperatura máxima em função da distância do centro da solda ao metal base, e que determina a extensão Zona Fundida e da Zona Afetada pelo Calor (ZAC), figura 3.6. Nos processos de soldagem automatizados a variação do ciclo térmico é pequena porque são mantidos constantes a distância entre a fonte de calor e a peça e também a velocidade de soldagem ${ }^{(3)}$.

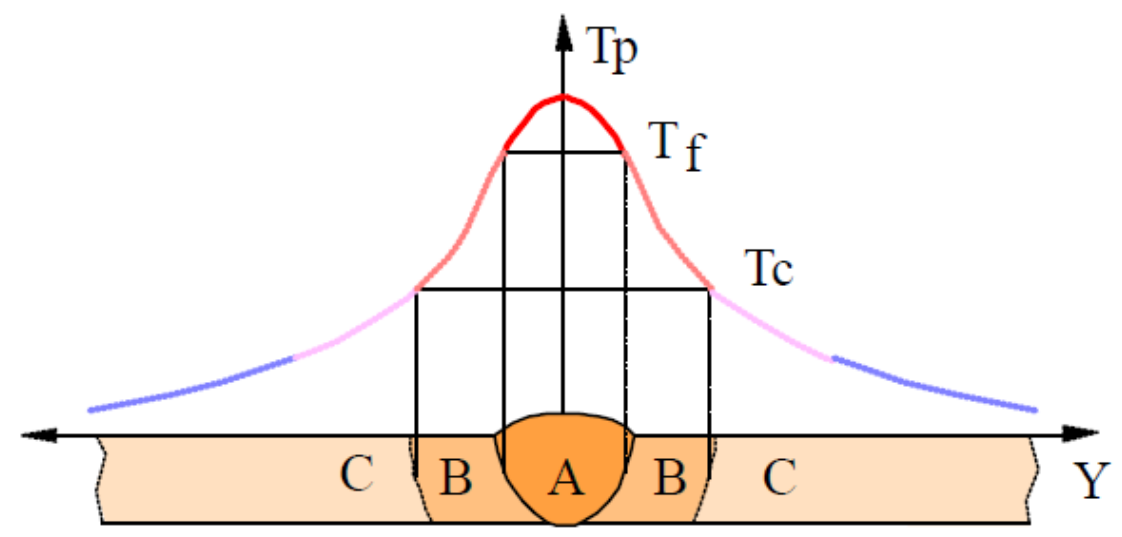

Figura 3.6: Representação da repartição térmica, Tp; temperatura de pico, Tf temperatura de fusão, Tc: temperatura crítica, A: zona fundida, B: zona afetada pelo calor e C: metal base ${ }^{(40)}$.

\subsubsection{HISTÓRIA TÉRMICA DA SOLDAGEM}

Denomina-se de história térmica a repartição térmica e os infinitos ciclos térmicos de soldagem de uma junta soldada, função das propriedades físicas do material, da temperatura inicial da chapa, da geometria da junta a ser soldada, da energia de soldagem e do formato da fonte de calor, figura $3.7^{(3)}$. 


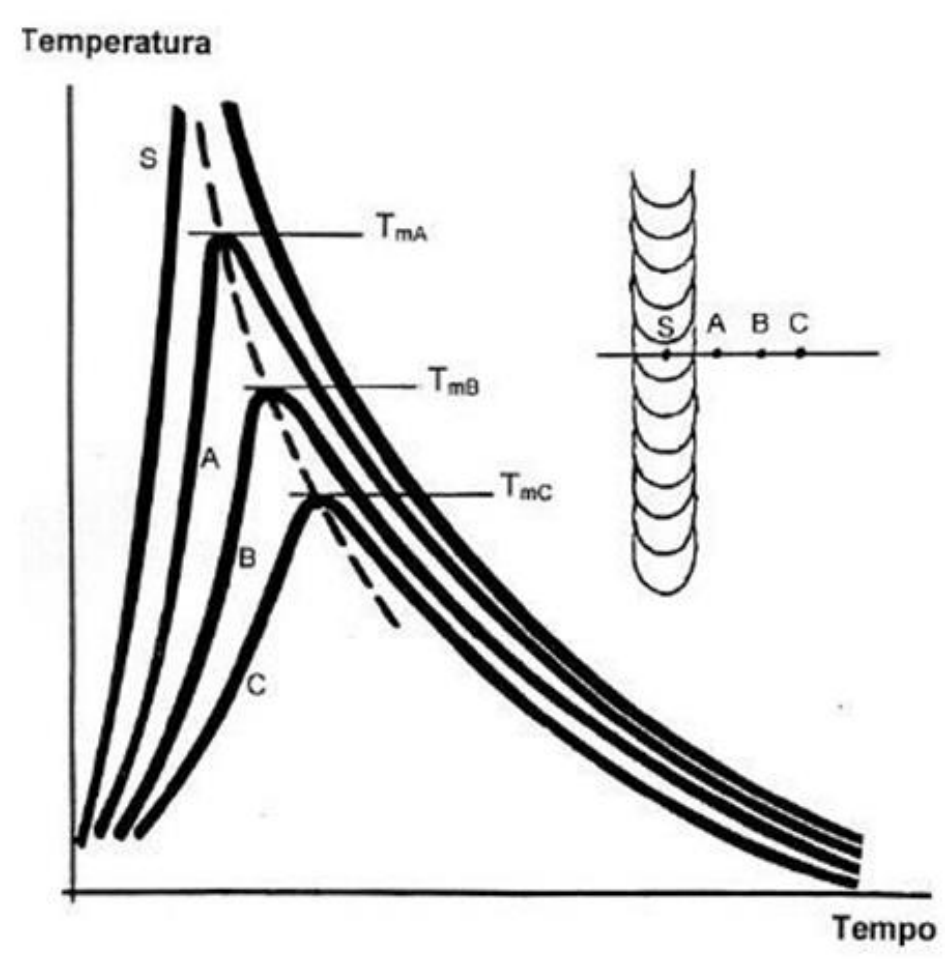

Figura 3.7: Representação dos vários ciclos térmicos, TmA; temperatura de pico no ponto $\mathrm{A}, \mathrm{TmB}$; temperatura de pico no ponto $\mathrm{B}, \mathrm{TmC}$; temperatura de pico no ponto $\mathrm{C}^{(4)}$.

\subsubsection{PRINCIPAIS PROCESSOS DE SOLDAGEM AO ARCO ELÉTRICO}

Os principais processos de soldagem ao arco elétrico consistem de um eletrodo conectado a uma fonte de energia elétrica que quando aproximado da peça a ser soldada, que também está conectada a fonte de energia, gera um arco elétrico capaz de produzir calor suficiente para fundir o metal de adição e as partes das peças a serem unidas. Parte do calor gerado pelo arco elétrico é dissipado no meio, e a relação entre o calor absorvido pelo metal e o calor gerado pelo arco é denominado de eficiência térmica do processo de soldagem, ou simplesmente rendimento, cada processo de soldagem tem seu rendimento próprio. Nos processos de soldagem ao arco elétrico os eletrodos podem ou não ser consumíveis, quando os eletrodos são os consumíveis também assumem o papel de metal de adição na soldagem. Dentre os vários processos de soldagem ao arco elétrico utilizados para a confecção de sistemas de tubulação em aço destacam-se o processo de soldagem com Eletrodo Revestido - SMAW (Shielded Metal Arc Welding), o processo de soldagem Mig/Mag - GMAW (Gas Metal Arc Welding), o processo de soldagem TIG - GTAW (Gas Tungsten Arc Welding), o processo de 
soldagem ao Arco Submerso - SAW (Submerged Arc Welding) e o processo de soldagem com Arame Tubular - FCAW (Flux Cored Arc Welding) que é o processo utilizado neste trabalho ${ }^{(3)}$.

\subsubsection{Arame Tubular - FCAW (Flux Cored Arc Welding)}

O processo de soldagem com arame tubular autoprotegido também conhecido por FCAW (Flux Cored Arc Welding) consiste de uma tocha com eletrodo consumível, que é um arame tubular alimentado de forma contínua e utilizado como metal de adição, que produz um arco elétrico em uma atmosfera proveniente do aquecimento de diversos elementos químicos presentes no interior (Core) do arame, denominado de fluxo não metálico de soldagem. Os gases provenientes do aquecimento desses elementos químicos são responsáveis também pela estabilidade do arco elétrico, peço fluxo do metal fundido e evitam a oxidação durante a soldagem. Esse processo também produz escória que cobre a solda e evita a oxidação do metal durante o resfriamento ${ }^{(3)}$. Neste processo também pode ser utilizado gás ou mistura de gases provenientes de um cilindro pressurizado de forma adicional, figura 3.8.

Existe uma variação do processo de soldagem do tipo FCAW (Flux Cored Arc Welding) que utiliza o arame tubular com alma metálica, denominado MCAW (Metal Cored Wire), onde no interior do arame tubular há um fluxo metálico e a atmosfera de proteção necessária à soldagem é exclusiva do gás proveniente de um cilindro pressurizado, podendo ser um único gás ou uma mistura de gases de acordo com os materiais a serem soldados ${ }^{(3)}$. 


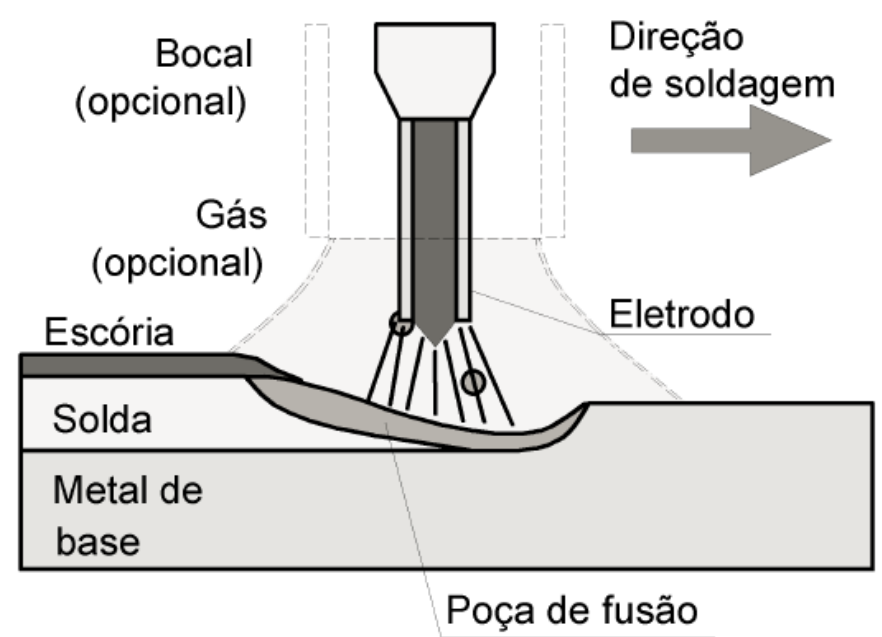

Figura 3.8: Representação do processo de soldagem com arame tubular (FCAW) ${ }^{(40)}$.

A composição do fluxo do arame tubular pode sofrer variações de acordo com a formulação de cada fabricante, as composições do fluxo são desenvolvidas para aplicações específicas, mas resumidamente o fluxo tem as funções básicas de desoxidante e formador de nitretos, formador de escória, estabilizador de arco, de adicionar elementos de liga ao metal de solda e de gerar gases para a proteção do arco elétrico ${ }^{(3)}$.

O manganês e o silício atuam como desoxidantes evitando a porosidade e a fragilização da solda causadas pelo oxigênio e nitrogênio, alguns fabricantes adicionam alumínio para formação de nitretos como purificador do metal de solda, óxidos de cálcio, potássio, silício e sódio protegem a poça de fusão do ar atmosférico e formam escória de rápida solidificação que melhoram o perfil da solda e também reduzem a taxa de resfriamento, que é desejável em alguns processos, e ainda o potássio e o sódio reduzem os respingos contribuindo para a obtenção de um arco mais suave e estável, outros elementos químicos como o cromo, níquel, molibdênio, vanádio, manganês e cobre são incorporados ao fluxo melhorando as propriedades mecânicas e de resistência a corrosão da solda, e no fluxo dos arames tubulares autoprotegidos são adicionados calcário, fluorita dentre outros minerais para a formação de uma atmosfera de proteção, conforme mostra a figura $3.9^{(3)}$. 


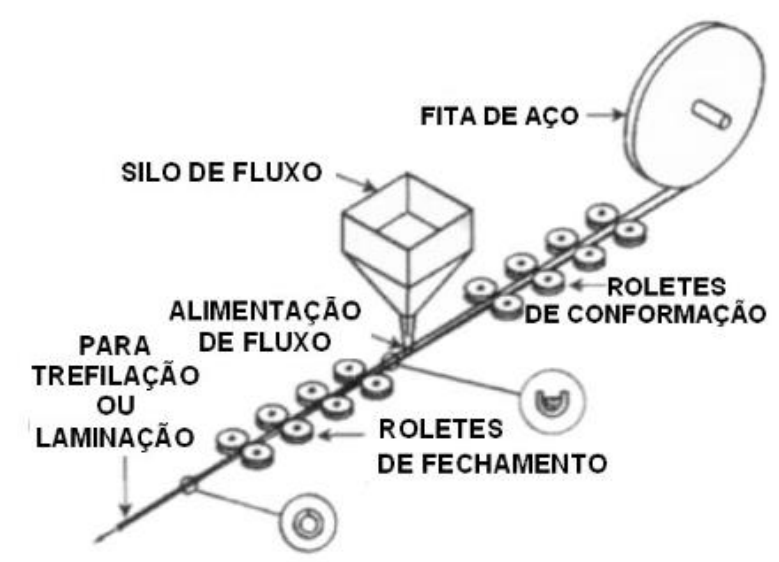

Figura 3.9: Representação esquemática do processo de fabricação do arame tubular. (ESAB OK Cored Wires - Product Brief, 1999)

Ainda de acordo com a composição do fluxo os arames tubulares podem ser classificados como básicos, rutílicos e metálicos. Os arames tubulares básicos são do tipo autoprotegidos, apresentam fluxo não metálico composto basicamente por minerais que liberam dióxido de carbono no arco, de forma adicional a presença de fluorita auxilia como fundente e também se volatiza isolando o arco do ar atmosférico, a composição do fluxo é ajustada para que seu ponto de fusão seja ligeiramente inferior ao do metal de solda, o que faz com que a escória cubra a solda e não seja retida no seu interior, este tipo de arame é ideal para soldagem de aços de baixa liga e média resistência, opera em corrente contínua positiva, proporciona elevadas taxas de deposição e produz poucos respingos, a escória formada é de fácil remoção e o cordão é regular. Os arames tubulares rutílicos também são do tipo autoprotegido e apresentam fluxo não metálico rutílico, uma forma de dióxido de titânio que atua como estabilizador de arco, outros minerais são adicionados ao fluxo para manter a temperatura de fusão da escória baixa uma vez que o rutílico fundese em temperaturas superiores a $1.700 \stackrel{\circ}{\circ}$, assim como os arames básicos, o rutílico também é ideal para soldagem de aços de baixa liga e média resistência, opera em corrente contínua positiva, proporciona elevadas taxas de deposição e produz poucos respingos, a escória formada é de fácil remoção e o cordão é regular, os arames tubulares rutílicos diferem dos arames tubulares básicos por possuir rutílico na composição do fluxo. Os arames tubulares metálicos não são autoprotegidos, portanto toda proteção gasosa necessária à soldagem deve ser proveniente de cilindros de gás ou de mistura de gases, esse tipo de arame tem o pó de ferro com 
principal componente e sem a presença de compostos minerais, outras variações contendo níquel, cromo, cobre, molibdênio, vanádio, manganês, dentre outros metais atuam na melhoria da tenacidade em baixas temperaturas, resistência mecânica, aumento da resistência à corrosão. A grande variedade de materiais dos arames e das composições de fluxo para os arames tubulares metálicos permite a soldagem de ligas não ferrosas, aços de alta resistência, aços de alta liga, aços inoxidáveis, aços inoxidáveis duplex e também de aços inoxidáveis superduplex ${ }^{(3)}$.

$\mathrm{Na}$ soldagem com arame tubular FCAW (Flux Cored Arc Welding) o modo como a transferência metálica, transferência do metal através do arco elétrico, acontece está diretamente ligada ao tipo de fonte de energia, características do arame e a composição da atmosfera de proteção, as diferentes combinações dessas variáveis afetam o modo de transferência metálica através do arco, denominadas como curtocircuito, Aerossol e globular ${ }^{(3)}$.

A transferência metálica por curto-circuito ocorre quando o arame toca a peça aumentando a corrente e fundindo $o$ arame e a partir dai ocorre uma série de curtoscircuitos toda a vez que o arame toca a poça de fusão, a variação da corrente depende dos parâmetros de soldagem, do diâmetro do arame e da distância de trabalho, em geral a corrente elétrica se mantém abaixo dos $200 \mathrm{~A}$, este modo de transferência metálica é ideal para chapas finas uma vez que o arco elétrico não atinge temperaturas muito altas, figura $3.10^{(3)}$.

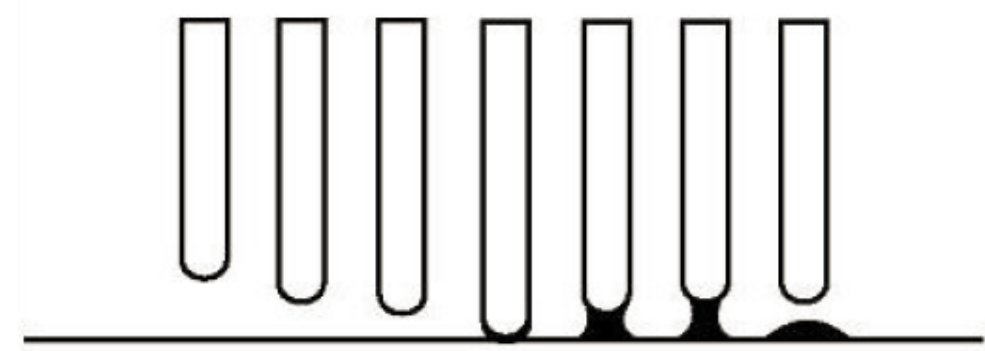

Figura 3.10: Representação esquemática da transferência metálica por curto-circuito. (ESAB OK Cored Wires - Product Brief, 1999) 
$\mathrm{Na}$ transferência metálica globular o arame atinge temperaturas elevadas e se funde formando grandes gotas de metal que são impulsionadas pela foça do arco. A frequência dos curtos-circuitos não ocorre de forma regular, em geral a corrente elétrica se mantém acima dos $200 \mathrm{~A}$, nem todas as gotas atingem a poça de fusão gerando uma grande quantidade de respingos, logo este tipo de transferência metálica deve ser evitada, figura $3.11^{(3)}$.

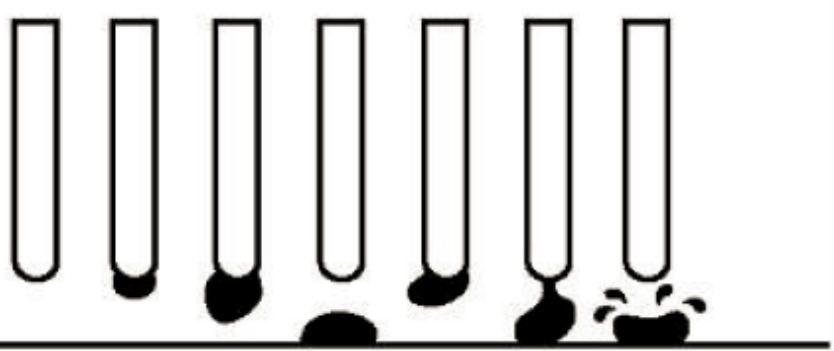

Figura 3.11: Representação esquemática da transferência metálica globular. (ESAB OK Cored Wires - Product Brief, 1999)

A transferência metálica do tipo Aerossol caracteriza-se por gotas extremamente finas projetadas através de um arco de comprimento constante, a transferência de metal é direcional, estável e não gera respingos, este tipo de transferência metálica ocorre quando a atmosfera de proteção é o gás argônio ou uma mistura de argônio e oxigênio e não causa curto-circuito. Na presença de uma atmosfera de proteção de dióxido de carbono ou uma mistura de dióxido de carbono e oxigênio forma-se um glóbulo na ponta do arame gerando gotas maiores que podem causar curto-circuito e este tipo transferência é denominada de quase globular ou falso Aerossol, figura $3.12^{(3)}$.

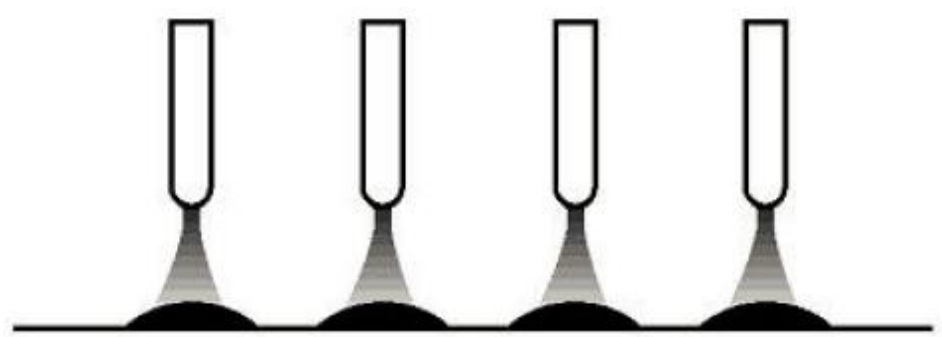

Figura 3.12: Representação esquemática da transferência metálica por Aerossol. (ESAB OK Cored Wires - Product Brief, 1999) 
Os consumíveis para soldagem com arame tubular FCAW (Flux Cored Arc Welding), bem como os demais consumíveis utilizados nos mais variados processos de soldagem, são classificados por normativas internacionais. No seguimento petroquímico as normativas mais comumente utilizadas são da AWS (American Welding Society) sociedade americana de soldagem, cujas normas vêm sendo desenvolvidas de acordo com as regras do ANSI (American National Standards Institute) instituto nacional de normas americanas, e os consumíveis são classificados de acordo a fonte de calor, limite de resistência, posição de soldagem, fluxo interno se houver, desempenho do eletrodo, proteção gasosa se necessária, requisitos de tenacidade e teor de hidrogênio difusível na $\mathrm{ZAC}^{(3)}$.

O processo de soldagem com arame tubular FCAW (Flux Cored Arc Welding), devido a alimentação contínua do arame é denominado de processo semiautomático, podendo a soldagem ser executada de forma manual ou automatizada, o processo automatizado pode ser empregado na soldagem de chapas retas e também de tubos de pequenos e grandes diâmetros, há uma grande variedade de arames tubulares disponíveis no mercado, o que permite que inúmeros metais, ferrosos e não ferrosos, possam ser soldados por este processo. Seu custo não é muito elevado e o transporte do equipamento é relativamente fácil, a soldagem é boa em várias posições, o que simplifica sua utilização em campo, sua operação é fácil e permite que um soldador com pouca habilidade tenha bom desempenho ${ }^{(3)}$.

\subsection{AÇOS INOXIDÁVEIS DUPLEX (AID)}

Os aços inoxidáveis duplex são uma liga de Fe-Cr-Ni-Mo-N, caracterizados por uma micro estrutura composta por duas fases, uma fase ferrítica e a outra austenítica, presentes de forma separada em quantidades e aproximadamente iguais, contendo uma quantidade de cromo ( $\mathrm{Cr}$ ) superior a 11\%. Sua descoberta se deu em 1927, sendo disponibilizado comercialmente na década de 1930, como uma alternativa mais econômica aos aços inoxidáveis austeníticos, devido a pouca quantidade de 
níquel em sua composição, de 4 a $7 \%$ comparados aos $10 \%$ ou mais existentes nos aços inoxidáveis austeníticos ${ }^{(1,2,3,4,5,6,7,8,9)}$.

Os aços inoxidáveis duplex somam inúmeras vantagens quando comparados aos aços inoxidáveis austeníticos, além de possuir elevada resistência mecânica, elevada resistência a corrosão generalizada e localizada puntiforme ou alveolar, também possuem excelente resistência a corrosão sob tensão e a corrosão induzida por cloretos $^{(1,2,3,4,5,6,7,8,9)}$.

Embora seu custo nos dias de hoje seja elevado, face ao crescente desenvolvimento de diversas ligas com as mais variadas composições químicas, tem se destacado como alternativa viável em longo prazo fazendo com que sua utilização na indústria marítima e em especial na indústria petroquímica venha aumentando de forma significativa, onde a combinação de suas propriedades mecânicas e de resistência a corrosão em faixas de temperatura de -50 a $250 \stackrel{\circ}{C}$ atende a uma gama de aplicações $^{(1,2,3,4,5,6,7,8,9)}$.

Devido a sua refinada estrutura os aços inoxidáveis duplex apresentam valores muito superiores de tensão de escoamento que os aços inoxidáveis austeníticos, comparativamente, do ponto de vista econômico, a resistência a corrosão sob tensão e a corrosão localizada puntiforme ou alveolar (Pitting Corrosion) dos aços inoxidáveis duplex supera a dos aços inoxidáveis austeníticos, contudo devido ao comportamento frágil da ferrita em temperaturas inferiores a $-50 \stackrel{\circ}{C}$ e pela formação de fases deletérias em temperaturas superiores a $250 \stackrel{\circ}{C}$, não são indicados para aplicações além destes limites de temperatura ${ }^{(1,2,3,4,5,6,7,8,9)}$.

Ultimamente, com o intuito de acelerar a formação da austenita durante o processo de soldagem e também de melhorar as propriedades de resistência a corrosão generalizada e em especial a resistência a corrosão localizada puntiforme ou alveolar, vem aumentado o uso de nitrogênio como elemento de liga substituindo porções de níquel $^{(1,2,3,4,5,6,7,8,9)}$. 


\subsection{AÇOS INOXIDÁVEIS SUPERDUPLEX}

A diferença básica entre os aços inoxidáveis duplex e os aços inoxidáveis superduplex está na concentração dos principais elementos de liga, tais como cromo $(\mathrm{Cr})$, níquel $(\mathrm{Ni})$, molibdênio $(\mathrm{Mo})$ e nitrogênio $(\mathrm{N})$, além da presença de outros elementos tais como o tungstênio $(\mathrm{W})$, que, junto com o Mo e o $\mathrm{N}$, aumentam a resistência a corrosão localizada puntiforme ou alveolar (Pitting Corrosion) $)^{(1,2,3,4,5)}$.

A capacidade de resistência a corrosão localizada puntiforme ou alveolar pode ser medida pela concentração dos elementos de liga presentes nestes aços, e estas propriedades podem ser quantificadas por meio de um valor denominado de número de resistência a corrosão localizada puntiforme ou alveolar, que é o somatório dos percentuais de $\mathrm{Cr}$, Mo, $\mathrm{N}$ e $\mathrm{W}$, este número é mais comumente conhecido como PRE (Pitting Resistance Equivalent) ${ }^{(1,2,3,4,5,6,7,8,9)}$.

O PRE é quantificado por meio de uma equação, os aços inoxidáveis com matriz ferrítica e austenítica com valores de PRE entre 32 e 40 são denominados de aços inoxidáveis duplex, e os aços inoxidáveis com matriz ferrítica e austenítica com valores de PRE superiores a 40 são denominados de aços inoxidáveis superduplex $^{(1,2,3,4,5,6,7,8,9)}$.

$$
\begin{aligned}
& \operatorname{PRE}_{N}=\% \mathrm{Cr}+3,3 \% \mathrm{Mo}+16 \% \mathrm{~N} \\
& \mathrm{PRE}_{\mathrm{W}}=\% \mathrm{Cr}+3,3 \% \mathrm{Mo}+1,65 \% \mathrm{~W}+16 \% \mathrm{~N}
\end{aligned}
$$

De acordo com a norma ASTM G48, que especifica os procedimentos para a elaboração de ensaios de resistência a corrosão por meio de ataque com soluções de cloretos, quanto maior o PRE maior a resistência a corrosão localizada puntiforme ou alveolar. 


\subsubsection{INFLUÊNCIA DOS ELEMENTOS DE LIGA NOS AÇOS INOXIDÁVEIS DUPLEX E SUPERDUPLEX}

Conforme mencionado anteriormente os elementos químicos adicionados aos aços inoxidáveis duplex e superduplex, denominados de elementos de liga, são responsáveis por conferir propriedades das mais diversas aos aços, dependendo do elemento, da sua concentração e também da associação com demais elementos ${ }^{(1,2,}$ $3,4,5,6,7,8,9)$.

Cada elemento químico, elemento de liga, possui uma característica própria de acordo com sua natureza, podem aumentar a resistência mecânica dependendo do tipo de ligação química, podem atribuir maior dureza ao aço, podem influir na formação de planos de escorregamento permitindo que o aço tenha sua ductilidade aumentada, podem melhorar a resistência a corrosão, dentre outras ${ }^{(1,2,3,4,5,6)}$.

Por outro lado alguns desses elementos de liga que tanto melhoram as características mecânicas dos aços inoxidáveis duplex e superduplex podem também produzir um efeito contrario pela formação de fases deletérias, reduzindo sensivelmente suas propriedades e até mesmo fragilizando sua estrutura quando submetidos a um processo de fundição e principalmente de soldagem $^{(1,2,3,4,5,6)}$.

Cada um dos vários elementos de liga utilizados na produção dos aços inoxidáveis duplex e superduplex possui características próprias, tais como tipo de estrutura cristalina, raio atómico, peso molecular, temperatura de fusão, entalpia de fusão, coeficiente de condutibilidade térmica, desta forma fazendo com que cada elemento tenha um comportamento distinto quando submetido a um processo que envolva fusão e solidificação( ${ }^{(1,2,3,4,5,6,7,8,9)}$.

Devido a essas diferenças nas características físicas de cada elemento de liga, durante um processo qualquer de soldagem, que faz com que os metais se fundam e em seguida se solidifiquem em uma única peça, a microestrutura do material pode ser comprometida, como por exemplo: Alguns desses elementos podem se precipitar, solidificando-se enquanto o restante do metal ainda está em estado 
líquido e se depositando nos contornos de grão fragilizando o metal. Devido à diferença de raios atômicos alguns desses elementos podem gerar defeitos cristalinos, substitucionais e intersticiais, o tamanho do grão pode ser afetado diminuindo a resistência mecânica do metal, o próprio balanço de ferrita e de austenita pode ser alterado favorecendo a corrosão dependendo do meio a que o material está exposto e da solicitação destes $\operatorname{aços}^{(1,2,3,4,5,6,7,8,9)}$.

\subsubsection{Principais Características do Cromo (Cr)}

O cromo é um metal duro e frágil, de elevada resistência a corrosão, que forma uma camada protetora de óxido de cromo, uma película passiva, desta forma aumentando a resistência a corrosão dos aços inoxidáveis. É responsável também pelo endurecimento da ferrita e da austenita, mas nos aços inoxidáveis duplex e superduplex é um dos elementos que compõe algumas fases deletérias tais como a fase Sigma $(\sigma)$, fase Chi $(X)$, fase $R$, a fase $P i(\pi)$, a austenita secundária e nitretos e carbonetos de cromo, que comprometem a resistência a corrosão e fragilizam o aço $^{(7,18,19,20)}$.

\subsubsection{Principais Características do Níquel (Ni)}

O níquel é um metal maleável, que confere ao aço ductilidade, tenacidade e resistência mecânica e também melhora sua resistência à corrosão. Durante a fase de solidificação dos aços Inoxidáveis duplex e superduplex altera a temperatura de transformação da austenita para ferrita e a cinética do crescimento de grão, conforme já mencionado anteriormente, é um metal de elevado custo e a quantidade utilizada nos aços inoxidáveis duplex e superduplex é apenas o mínimo necessário para se conseguir uma microestrutura ferrítica e austenítica ${ }^{(7,18,19,20)}$. 


\subsubsection{Principais Características do Silício (Si)}

O silício é um elemento muito duro e pouco solúvel, confere dureza aos aços e resistência a ácidos, se dissolve na ferrita ${ }^{(7,18,19,20)}$.

\subsubsection{Principais Características do Manganês (Mn)}

O manganês é um metal duro e muito frágil, confere dureza aos aços inoxidáveis e reduz a temperatura de formação da austenita, nos aços inoxidáveis duplex e superduplex e também substitui de forma parcial o níquel diminuindo o custo de produção destes $\operatorname{aços}^{(7,18,19,20)}$.

\subsubsection{Principais Características do Molibdênio (Mo)}

O molibdênio é um metal muito duro, com elevado ponto de fusão atuando como estabilizador da ferrita, confere dureza, resistência química e a corrosão localizada puntiforme ou alveolar dos aços, mas nos aços inoxidáveis duplex e superduplex é um dos elementos que compõe algumas fases deletérias tais como a fase Sigma $(\sigma)$, fase Chi $(X)$, fase $R$, fase $P i(\pi)$ e a austenita secundária, que comprometem a resistência a corrosão e fragilizam estes $\operatorname{aços}^{(7,18,19,20)}$.

\subsubsection{Principais Características do Nitrogênio (N)}

O nitrogênio é um gás inerte que ocorre na natureza, presente no ar atmosférico, utilizado como gás de proteção em inúmeros processos de soldagem, aumenta a resistência à corrosão e conforme mencionado anteriormente o nitrogênio vem sendo utilizado como elemento de liga visando a diminuição do uso do níquel nos aços inoxidáveis duplex e superduplex para formação da austenita, porém o excesso de nitrogênio na ferrita se precipita com nitreto de cromo durante a solidificação, 
além compor algumas fases deletérias tais como a fase $\mathrm{Pi}(\pi)$ e nitretos de cromo, que comprometem a resistência a corrosão e fragilizam estes $\operatorname{aços}^{(7,18,19,20)}$.

\subsubsection{Principais Características do Cobre (Cu)}

O cobre é um metal dúctil e maleável, que melhora as propriedades mecânicas dos aços aumentando seus limites de resistência e de escoamento, aumenta também a resistência a corrosão, mas nos aços inoxidáveis duplex e superduplex é um dos elementos que compõe algumas fases deletérias tais como a fase $\mathrm{Pi}(\pi)$ e outras não descritas neste trabalho e que também comprometem a resistência a corrosão e fragilizam estes $\operatorname{aços}^{(7,18,19,20)}$.

\subsubsection{Principais Características do Tungstênio (W)}

O tungstênio é um metal frágil, possui baixo coeficiente de expansão térmica, melhora a resistência a tração e a abrasão nos aços, também eleva a resistência ao ataque de ácidos e favorece a retenção do cobre nos aços inoxidáveis duplex e superduplex ${ }^{(7,18,19,20)}$.

\subsubsection{Principais Características do Cobalto (Co)}

O cobalto é um metal duro e nos aços melhora a resistência a corrosão e a resistência mecânica em elevadas temperaturas ${ }^{(7,18,19,20)}$.

\subsubsection{Principais Características do Enxofre (S)}

O enxofre é um elemento químico não metálico, o controle da presença deste elemento na composição dos aços é de suma importância face as suas características deletérias que reduzem sensivelmente a tenacidade e a ductilidade destes materiais fragilizando-os nas baixas temperaturas ${ }^{(7,18,19,20)}$. 


\subsubsection{Principais Características do Fósforo $(P)$}

O fósforo é um elemento químico não metálico, o controle da presença deste elemento na composição dos aços também é importante face as suas características deletérias que diminuem a resistência à corrosão e a ductilidade fragilizando-os nas baixas temperaturas ${ }^{(7,18,19,20)}$.

\subsubsection{FASES DOS AÇOS INOXIDÁVEIS DUPLEX E SUPERDUPLEX}

Os aços inoxidáveis duplex e superduplex, conforme mencionado anteriormente, são compostos basicamente por duas fases, figura 3.13, ferrita e austenita, em proporções de $50 \%$ cada, podendo ter alguma variação, como de até $40 \%$ a $60 \%$. Porém dependendo do processo utilizado na confecção de produtos a partir desses aços, peças fundidas e soldadas, pode surgir uma grande variedade de fases secundárias indesejáveis que comprometem as principais qualidades desses aços, como mostra a tabela $3.1^{(1,2,3,4,5,6,7,8,9)}$.

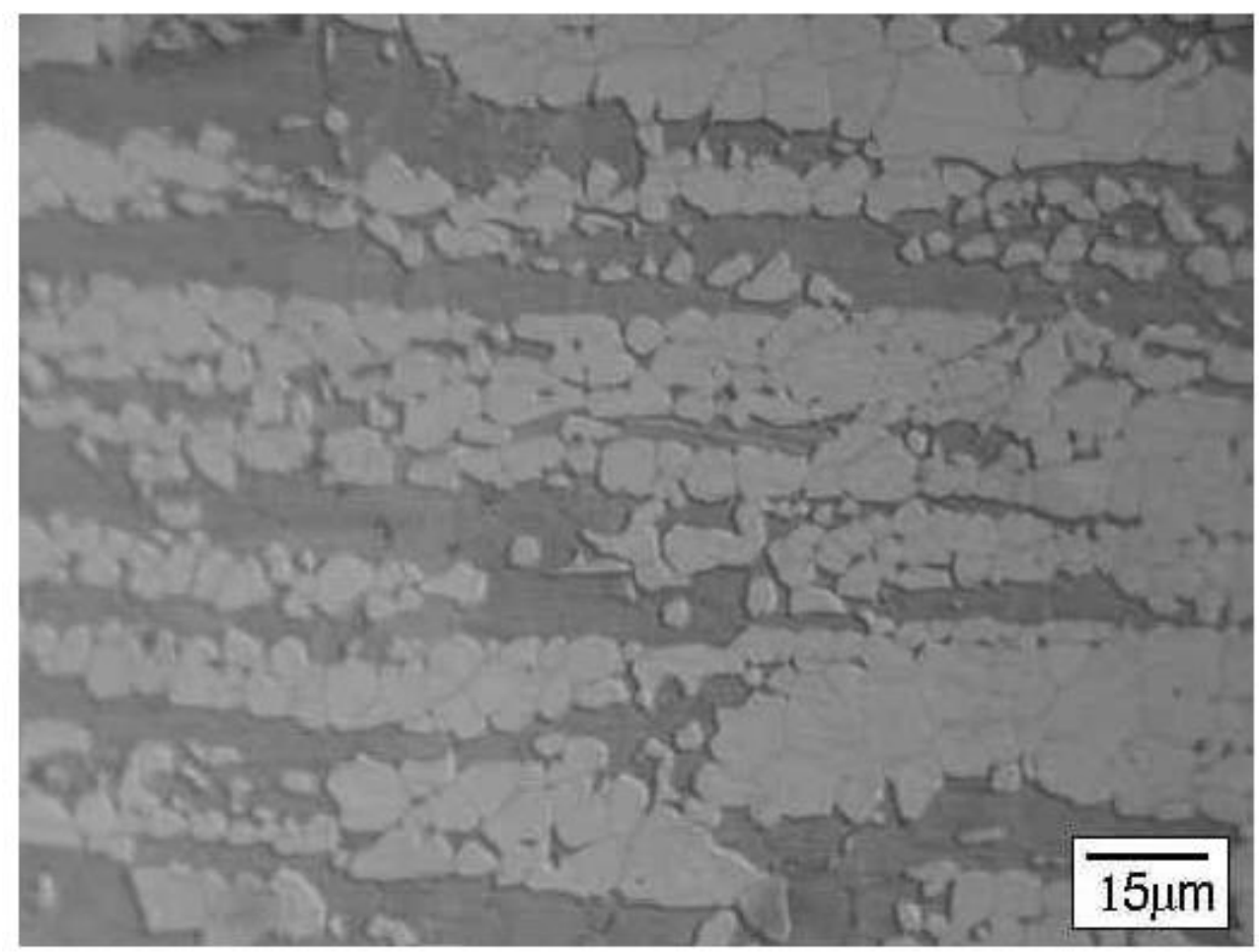

Figura 3.13: Microestrutura de um aço inoxidável duplex. A ferrita é identificada pela parte escura e a austenita pela parte clara da figura. (Alvarez - Armas, 2009) 
Tabela 3.1: Quadro resumo da composição das principais fases secundárias e suas temperaturas de precipitação nos aços inoxidáveis superduplex ${ }^{(7,18,19,20)}$.

\begin{tabular}{|c|c|c|c|c|c|c|}
\hline Fase & Composição & $\begin{array}{c}\text { Temp. de Precipitação } \\
\left({ }^{\circ} \mathrm{C}\right)\end{array}$ & $\% \mathrm{Fe}$ & $\% \mathrm{Cr}$ & $\% \mathrm{Ni}$ & $\%$ Mo \\
\hline Sigma $(\sigma)$ & Fe-Cr-Mo & $650-1000$ & 55,0 & 29,0 & 5,0 & 11,0 \\
\hline Chi (x) & Fe-Cr-Mo & $700-900$ & 48,2 & 26,7 & 3,3 & 21,8 \\
\hline $\mathrm{R}$ & Fe-Cr-Mo & $550-800$ & 30,0 & 25,0 & 35,0 & 35,0 \\
\hline $\mathrm{Pi}(\pi)$ & Fe-Mo-N & $550-600$ & 28,0 & 35,0 & 3,0 & 34,0 \\
\hline Austenita Secundaria & $\mathrm{Fe}-\mathrm{Cr}-\mathrm{Ni}-\mathrm{Mo}$ & $600-1000$ & 56,8 & 25,3 & 11,2 & 2,4 \\
\hline Nitretos & $\mathrm{Cr}-\mathrm{N}$ & $550-1000$ & 4,6 & 85,5 & - & 4,8 \\
\hline Carbonetos & M7-C3 & $550-900$ & 35,0 & 60,0 & 2,0 & 3,0 \\
\hline Carbonetos & M23-C6 & $550-900$ & 35,0 & 60,0 & 2,0 & 3,0 \\
\hline
\end{tabular}

Uma grande variedade de fases secundárias pode ser formada em uma faixa de temperaturas de 300 a $1.000 \stackrel{\circ}{ } \mathrm{C}$, figura 3.14 , bem como os nitretos e carbonetos, intergranulares ou localizados nos contornos de grão fragilizando o material. As fases secundárias mais comuns são a fase Sigma $(\sigma)$, fase Khi $(X)$, fase $R$, fase $P i$ (T) e a austenita secundária. A fase Sigma é a mais significativa por afetar a resistência a corrosão e também por enfraquecer o aço tornando-o frágil, geralmente se sobrepõe as demais fases dificultando a identificação destas outras fases ${ }^{(7,18,19}$, 20).

A maioria das fases deletérias que podem se precipitar nos aços inoxidáveis duplex e superduplex são ricas em cromo e molibdênio e a precipitação destas fases deletérias pode causar a diminuição da concentração destes elementos na matriz e conforme descrito anteriormente as propriedades de resistência a corrosão e de resistência mecânica atribuídas aos aços por estes elementos podem ser diminuídas e/ou comprometidas ${ }^{(7,18,19,20)}$. 


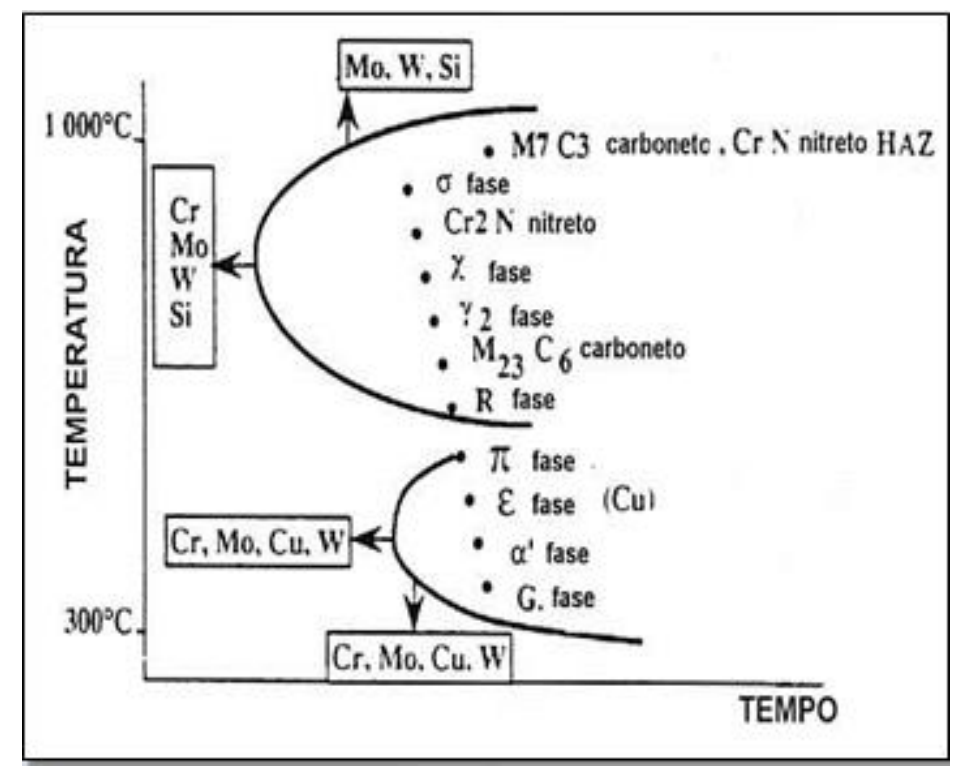

Figura 3.14: A curva tempo temperatura apresenta a cinética de precipitação das fases secundárias intermetálicas $^{(1,2,3,4,5,6,7,8,9)}$.

\subsubsection{Fase Sigma $(\sigma)$}

A fase Sigma é formada em uma grande variedade de Aços Inoxidáveis Duplex, porém com mais facilidade nos Aços Inoxidáveis Superduplex devido as maiores quantidades de Cromo e de Molibdênio presentes nestes aços. O Molibdênio é responsável pelo aumento da estabilidade da fase Sigma em altas temperaturas ${ }^{(1,2,}$ $3,4,5,6,7,8,9,18,19,20)$.

Além do Cromo e do Molibdênio também o Tungstênio e o Cobre contribuem para a formação desta fase indesejável, que geralmente ocorre no encontro de contornos de três grãos ou no encontro da ferrita com a austenita. Uma forma de minimizar ou até mesmo eliminar a fase Sigma é o tratamento térmico que faz com que essa fase seja diluída e absorvida pelos elementos formadores de ferrita ${ }^{(1,2,3,4,5,6,7,8,9,20)}$.

\subsubsection{Fase Chi $(X)$}

A fase Chi é encontrada em pequenas quantidades nos Aços Inoxidáveis Duplex em faixas de temperatura de 700 a $900 \stackrel{\circ}{\circ}$, esta fase coexiste com a fase Sigma e afeta 
a resistência a corrosão e a resistência mecânica, esta fase é de difícil detecção somente sendo identificada por meio de imagens geradas em microscópios eletrônicos com uso de elétrons retroespalhados ${ }^{(1,2,3,4,5,6,7,8,9,20)}$.

\subsubsection{Fase $R$}

A fase $R$ é se precipita entre 550 e $800{ }^{\circ} \mathrm{C}$ nos Aços Inoxidáveis Duplex, nas interfaces ferrita/austenita, tanto granulares quanto intergranulares, é um intermetálico rico em Molibdênio, e antecede a fase Sigma e pode ser mais facilmente identificado por difração de elétrons. A presença desta fase reduz a resistência mecânica e também afeta a resistência a corrosão localizada puntiforme ou alveolar $(1,2,3,4,5,6,7,8,9,20)$.

\subsubsection{Fase Pi ( $\pi)$}

A fase PI é encontrada dentro do grão nos Aços Inoxidáveis Duplex reduzindo sua resistência a corrosão localizada puntiforme ou alveolar e aumentado a fragilidade do material ${ }^{(1,2,3,4,5,6,7,8,9,20)}$.

\subsubsection{Austenita Secundária}

A formação da austenita secundária ocorre pela decomposição da ferrita metaestável em austenita (resultante de um resfriamento rápido). A austenita secundária pode se formar na interface ferrita/austenita primária ou no interior da ferrita e tem efeito deletério na resistência a corrosão ${ }^{(1,2,3,4,5,6,7,8,9,20)}$.

\subsubsection{Nitretos}

Os nitretos se precipitam em temperaturas na faixa de 700 a $900 \stackrel{\circ}{\circ}$, sua formação geralmente ocorre nos rápidos resfriamentos pelo efeito da saturação de nitrogênio na ferrita, os precipitados geralmente são intergranulares e se depositam nos 
contornos de grão nas interfaces ferrita/austenita, afetando a resistência a corrosão localizada puntiforme ou alveolar e fragilizando o metal ${ }^{(1,2,3,4,5,6,7,8,9,20)}$.

\subsubsection{Carbonetos}

Os carbonetos (carbetos) se precipitam em temperaturas abaixo dos $950{ }^{\circ} \mathrm{C}$ depositando-se nos contornos de grão e principalmente nas interfaces ferrita/austenita, podendo causar corrosão intergranular. Sua formação é desprezível nos Aços Inoxidáveis Duplex atuais ${ }^{(1,2,3,4,5,6,7,8,9,20)}$.

\subsubsection{SOLDABILIDADE DOS AÇOS INOXIDÁVEIS DUPLEX}

A aplicação dos aços inoxidáveis duplex na indústria de óleo e gás envolve algum processo onde se faça necessária a fusão e a solidificação do material, como por exemplo, a fabricação de válvulas onde os corpos são fundidos, flanges que são forjadas e a própria união de tubos por soldagem, por este motivo existe hoje uma grande quantidade de trabalhos acadêmicos sobre soldagem destes aços, o que resultou no desenvolvimento e melhoria das ligas atuais que tem uma boa soldabilidade, contudo, como já mencionado anteriormente a soldagem destes aços requer controle rígido da energia de soldagem para não comprometer as propriedades de resistência a corrosão e mecânica que tornam esses aços tão especiais $^{(1,2,3,4,5,6,7,8,9,18,19,20)}$.

Nos processos de soldagem dos aços inoxidáveis duplex uma das maiores dificuldades é a de controlar os ciclos térmicos de modo a manter o balanço de fases o mais próximo do encontrado no metal de base, controlar o crescimento de grão e evitar a formação de fases secundárias indesejáveis e a precipitação de carbonetos (carbetos) e nitretos ${ }^{(1,2,3,4,5,6,7,8,9,18,19,20)}$.

A soldagem desses aços pode ser realizada através de diversos processos, cada processo pode alterar o aço de forma diferente, sendo que alguns desses processos 
podem ser executados tanto manualmente como de forma automatizada. Nos processos manuais mesmo que os parâmetros de soldagem tenham sido corretamente definidos pode haver grande variação do ciclo térmico uma vez que existe a total dependência da habilidade e também do estado do soldador, outros fatores também devem ser considerados tais como a preparação dos chanfros, usinagem e limpeza, utilização de cobre juntas se aplicável, e na soldagem de tubos deve ser utilizado gás de purga no interior dos tubos para evitar a contaminação com o oxigênio do ar durante a solidificação do metal de solda, até mesmo a escova de aço utilizada para a retirada da escória da solda deve ser de aço inoxidável para evitar a contaminação com o aço carbono ${ }^{(1,2,3,4,5,6,7,8,9,18,19,20)}$.

Nos processos automatizados a variação dos ciclos térmicos é praticamente nula, uma vez definidos os parâmetros de soldagem e feito o correto ajuste do equipamento o ciclo térmico é mantido constante durante todo processo de soldagem, garantido uniformidade na solda e na zona adjacente a solda, Zona Afetada pelo Calor (ZAC), minimizando assim os impactos causados a microestrutura, mantendo o balanço de fases adequado e minimizando a formação de fases deletérias indesejáveis que diminuem a resistência a corrosão e mecânica destes $\operatorname{aços}^{(1,2,3,4,5,6,7,8,9,18,19,20)}$.

Uma elevada energia de soldagem, dependendo das dimensões da peça, pode gerar uma baixa velocidade de resfriamento da junta, favorecendo a precipitação da austenita, precipitação de fases intermetálicas e crescimento de grão mesmo mantendo a microestrutura equilibrada, e um aporte baixo de calor, dependendo das dimensões da peça, pode gerar uma elevada velocidade de resfriamento da junta, dificultando a precipitação de austenita e produzindo uma fração elevada de ferrita além poder ocorrer a precipitação de nitretos de cromo na ferrita do metal de solda, de qualquer forma pode haver uma diminuição na resistência a corrosão, na resistência mecânica e na tenacidade destes aços, portanto a máxima temperatura alcançada durante a soldagem, o tempo de permanência nestas condições, a temperatura de pré-aquecimento da peça (se necessário), o controle de temperatura de interpasses e também as dimensões da peça, tanto a espessura quanto largura, bem com as propriedades físicas do material, são fatores determinantes na dissipação de calor e, pode-se dizer, de forma resumida, que o aquecimento e 
resfriamento, figura 3.15 , são fatores determinantes para evitar danos na microestrutura dos aços inoxidáveis duplex ${ }^{(1,2,3,4,5,6,7,8,9,18,19,20)}$.

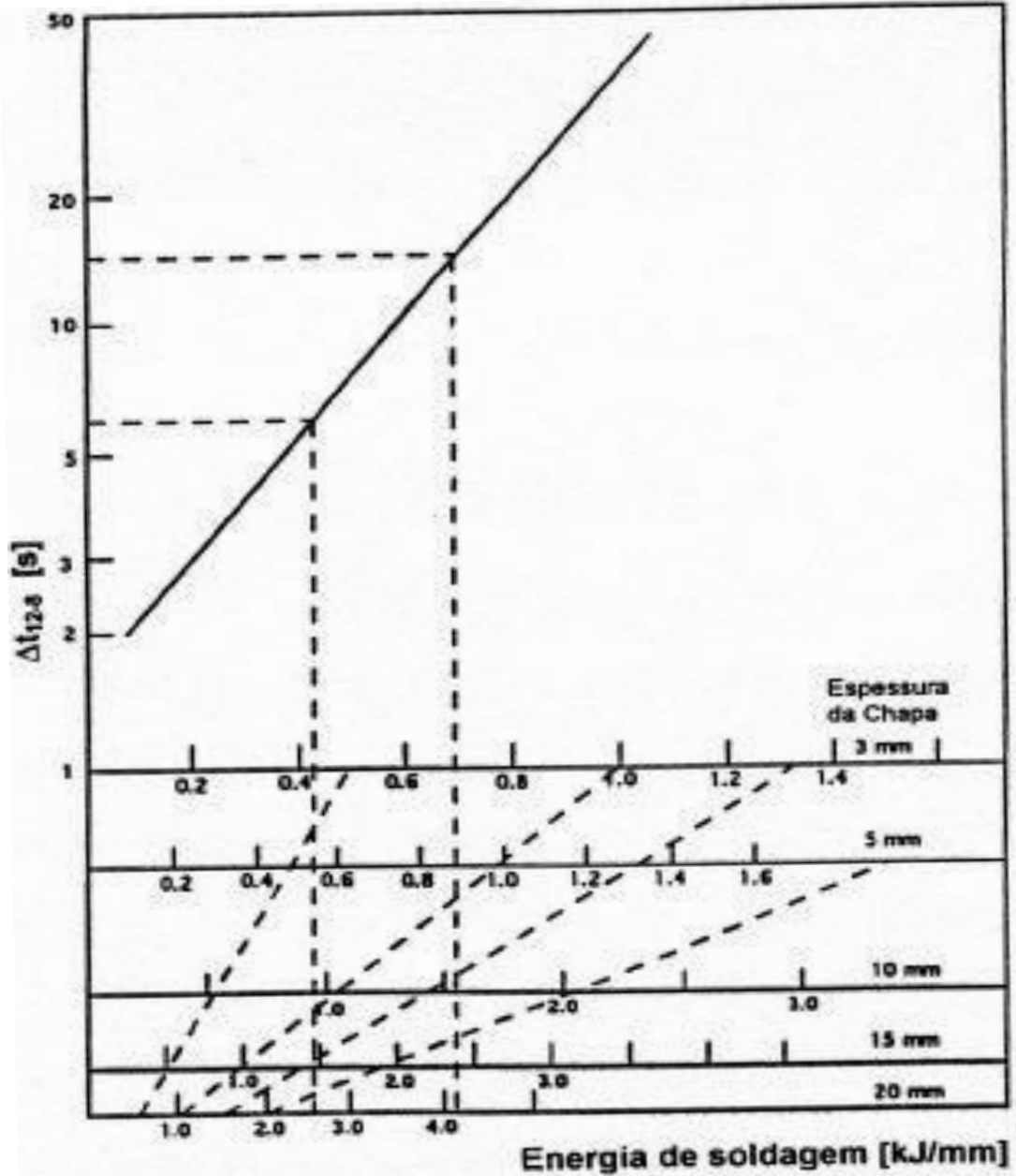

Figura 3.15: Curva tempo de resfriamento para temperatura de $1200{ }^{\circ} \mathrm{C}$ a $800{ }^{\circ} \mathrm{C}$ em função da energia de soldagem e da espessura da chapa ${ }^{(7,14)}$.

Após a soldagem a tenacidade dos aços inoxidáveis duplex pode ficar comprometida como já mencionado acima, o nitrogênio como elemento de liga estabiliza a austenita e aumenta sua precipitação a partir da ferrita e melhora a soldabilidade, porém atua de forma a aumentar a precipitação de nitretos na Zona Afetada pelo Calor (ZAC), outro fator negativo se deve a ação direta da temperatura atingida durante a soldagem e da taxa de resfriamento que aumenta a quantidade de ferrita $e$ também podendo favorecer o aparecimento da fase sigma, estes dois fatores são responsáveis pela fragilização do material nesta região e por favorecer o

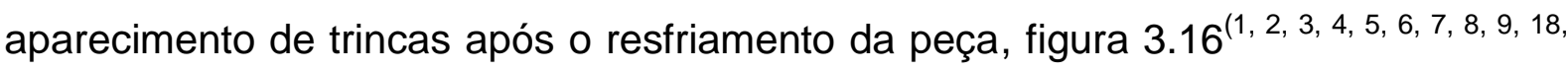
19, 20) 


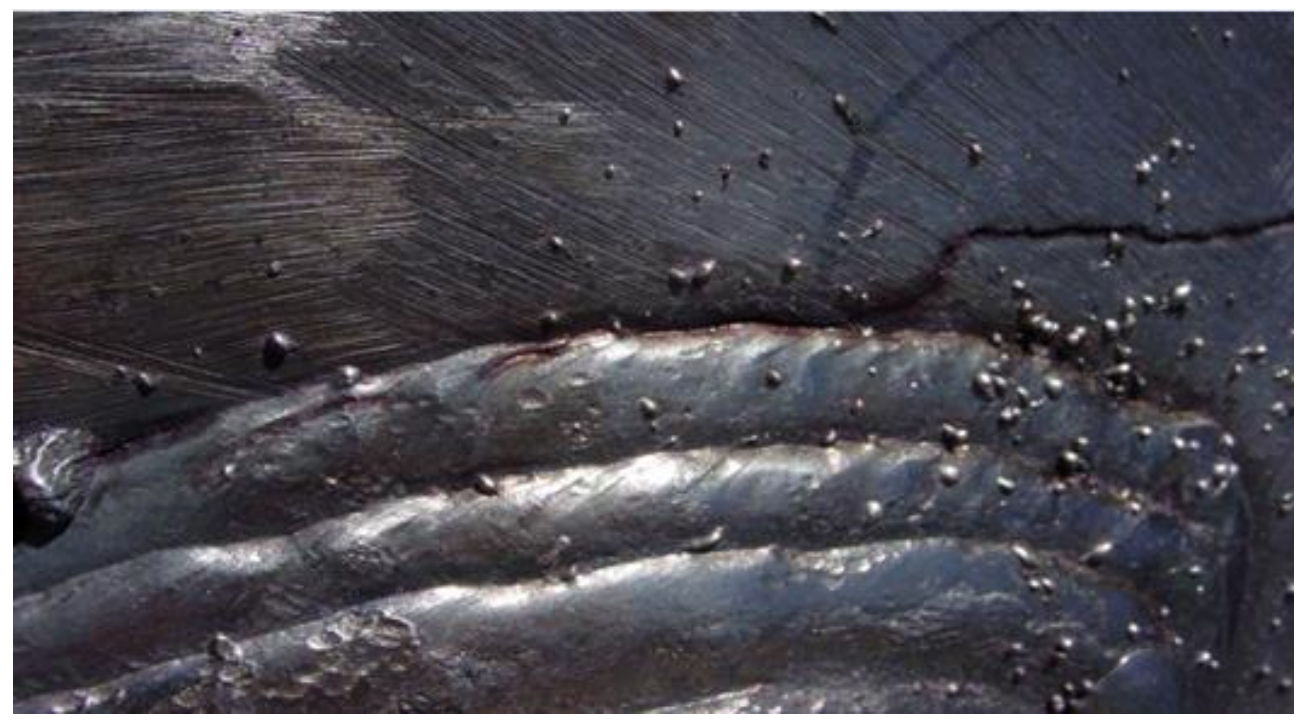

Figura 3.16: Exemplo de trinca na zona afetada pelo calor (ZAC), devido a diferença de espessuras entre o bocal e o casco, de um equipamento em aço inoxidável superduplex ${ }^{(14)}$.

$O$ aquecimento e resfriamento durante a soldagem podem elevar a quantidade de ferrita no metal de solda diminuindo a resistência a corrosão e também a tenacidade, portanto outro fator importante é a escolha do consumível adequado, os consumíveis para soldagem de aços inoxidáveis duplex e superduplex possuem percentual de níquel superior ao do metal de base, em média $25 \%$ maior, o que altera a cinética do crescimento de grão e da transformação da austenita em ferrita, desta forma aumentando a quantidade de austenita na solda. Além do teor maior de níquel no consumível outra forma de controlar o teor de austenita na solda é a adição de nitrogênio no consumível ou no gás de proteção. Como a solidificação é ferrítica o uso de consumíveis inadequados pode diminuir de maneira significativa a quantidade de austenita na solda. A figura 3.17 mostra um exemplo real de uso de consumíveis inadequados para a soldagem de uma tubulação em aço inoxidável superduplex, onde o fator econômico levou à utilização de consumíveis com teor de níquel inferior ao do metal de base, a quantidade de ferrita na solda aumentou significativamente, e face ao diferencial de potencial elétrico entre a ferrita da solda e a austenita do metal base ocorreu um fenômeno conhecido como corrosão preferencial, onde na presença de um fluido agressivo, eletrólito, a ferrita foi consumida e a solda falhou ${ }^{(1,2,3,4,5,6,7,8,9,18,19,20)}$. 


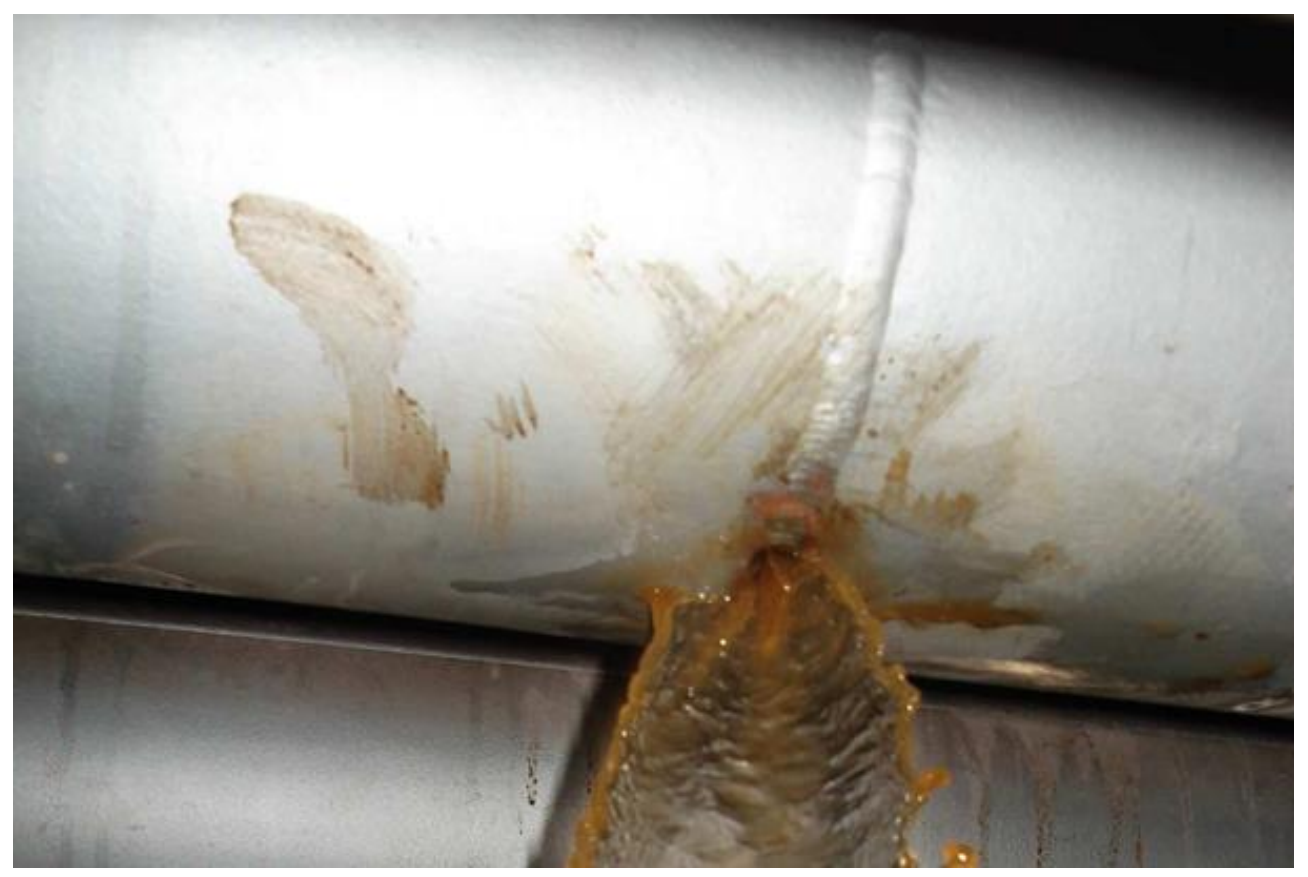

Figura 3.17: Exemplo de falha em uma solda de uma linha em aço inoxidável superduplex devido a desproporção no balanço de fases e na presença de um fluído agressivo ${ }^{(7,14)}$.

Conforme mencionado o aquecimento e resfriamento durante a soldagem são fatores extremamente importantes para evitar danos à microestrutura dos aços inoxidáveis duplex e na soldagem multipasses o risco de causar danos é maior devido ao reaquecimento do metal de solda (MS) e da zona afetada pelo calor (ZAC) da soldagem anterior, que causa alterações microestruturais nestas duas regiões, que já sofreram mudanças microestruturais causadas pelos ciclos térmicos a que foram submetidas anteriormente e o repetido reaquecimento destas áreas pode favorecer a precipitação de algumas fases deletérias tais como a fase Sigma $(\sigma)$, fase Chi $(X)$, fase $R$, fase $\mathrm{Pi}(\pi)$, a austenita secundária e nitretos e carbonetos de cromo, que comprometem a resistência a corrosão e fragilizam o material ${ }^{(34,35,36)}$.

Por outro lado o aumento do número de passes pode levar a uma melhora da resistência à corrosão da junta soldada quando utilizada uma baixa energia de soldagem e quando utilizada uma elevada energia de soldagem não se altera a resistência à corrosão com o número de passes, na soldagem multipasses com temperaturas elevadas e consequentemente com o reaquecimento da zona afetada pelo calor, pode precipitar austenita intergranular e levar ao crescimento da 
austenita intergranular dissolvendo parcial ou totalmente os nitretos e gerando um aumento no teor de nitrogênio na matriz ${ }^{(52,101,102,162,172)}$.

Em uma junta soldada de um aço inoxidável duplex, conforme mencionado anteriormente ocorrem modificações microestruturais, e pode-se observar cinco regiões distintas tais como Zona Fundida (ZF), Zona Parcialmente Fundida, Zona de Crescimento de Grão Ferrítico, Zona de Transformação Parcial e a Zona de Metal de

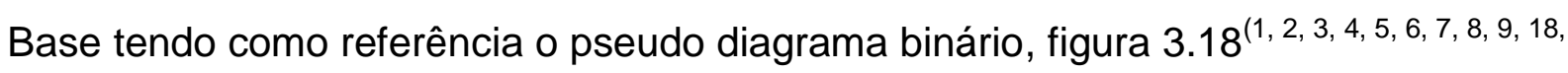
19, 20)

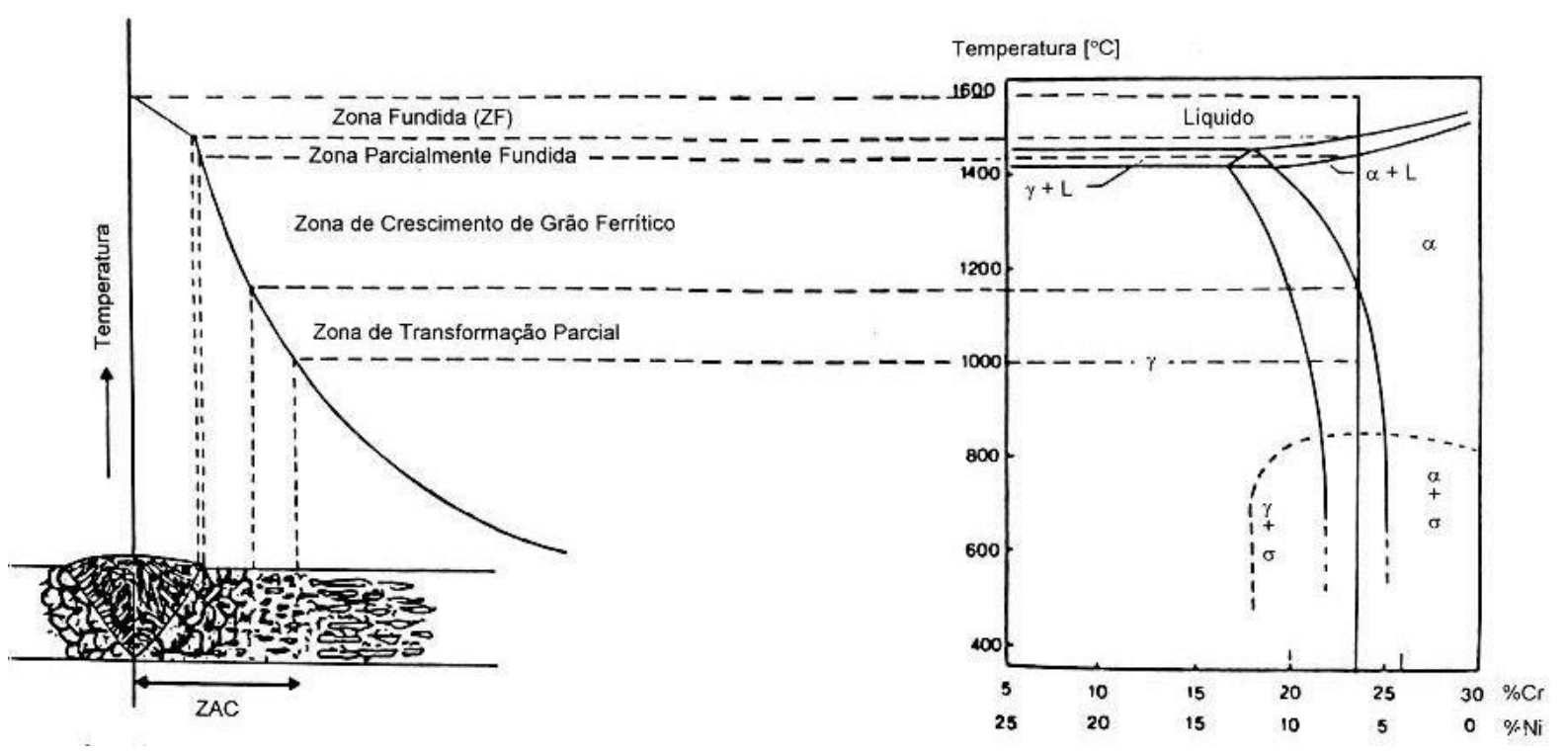

Figura 3.18: Diagrama de alterações microestruturais na soldagem de Aços Inoxidáveis Duplex ${ }^{(7,14)}$.

Durante a solidificação da zona fundida forma-se uma estrutura colunar grosseira devido ao crescimento epitaxial dos grãos de ferrita influenciada pelo tamanho de grão da zona afetada pelo calor. Como os mecanismos das transformações no estado sólido dentro da zona fundida são praticamente os mesmos na zona afetada pelo calor o mesmo acontece nesta zona ${ }^{(1,2,3,4,5,6,7,8,9,18,19,20)}$.

Conforme mencionado anteriormente a composição química da zona fundida pode ser controlada pela composição do consumível e também pela composição da atmosfera de proteção e com o controle do ciclo térmico tem-se o controle da quantidade de austenita e da precipitação de nitretos no metal de solda que apresenta uma maior quantidade de austenita intergranular devido a maior quantidade de inclusões na zona fundida que favorecem a nucleação desta austenita $^{(1,2,3,4,5,6,7,8,9,18,19,20)}$. 


\subsection{PRINCIPAIS NORMAS DE REFERÊNCIA PARA INDÚSTRIA DE ÓLEO E GÁS}

As principais normas utilizadas como referência na indústria do petróleo e gás, para unidades terrestres (On Shore) e unidades marítimas (Off Shore) são as normas das entidades ASME, ASTM, AWS, NACE, ANSI, API e adicionalmente NORSOK.

ASME (American Society of Mechanical Engineers) foi fundada em 1880 para fornecer referências para os engenheiros poderem discutir suas preocupações trazidas pelo crescimento da industrialização e da mecanização. A história da ASME é rica em publicações, normas técnicas, teorias, jornais técnicos dentre outros para os mais variados segmentos da indústria ${ }^{(57)}$.

ASTM (American Society for Testing and Mateirals) foi fundada em 1898 por químicos e engenheiros da companhia ferroviária da Pensilvânia para o estudo da composição e de propriedades de materiais. $\mathrm{Na}$ ocasião de sua fundação a organização era conhecida por American Section of the International Association for Testing and Materials. Hoje a ASTM é responsável por mais de 12.000 normas técnicas para materiais e testes, suas publicações atendem as necessidades de diversos ramos da indústria ${ }^{(58)}$.

AWS (American Welding Society) nasceu durante a primeira guerra mundial devido as repentinas demandas da indústria bélica, com o objetivo de padronizar os processos de fabricação de equipamentos militares, com foco na qualidade e na segurança da soldagem. Em 1922 a AWS iniciou a publicação semanal de um jornal técnico de soldagem, hoje este jornal é mensal. Atualmente a AWS dedica-se ao desenvolvimento científico e tecnológico da soldagem e posse mais de 100 normas técnicas e procedimentos de soldagem para materiais diversos, incluindo plásticos e compósitos $^{(59)}$.

NACE (National Association of Corrosion Engineers) iniciou suas atividades em 1943 como uma organização de profissionais dedicados ao controle da corrosão na indústria, seus objetivos principais são a publicação de normas para seleção, projeto, instalação e operação com materiais onde a corrosão é um fator importante, 
bem como a elaboração de normas e padrões para realização de testes para a prevenção e o controle da corrosão. Suas publicações são divididas em três classes, Práticas Recomendadas, Metodologia de Testes e Requisitos de Materiais ${ }^{(60)}$.

ANSI (Americam National Standard Institute) foi criado em 1916 como um comitê de normas americanas de engenharia compostos por sociedades e institutos técnicos como o IEEE (American Institute of Electrical Engineers), ASME (American Society of Mechanical Engineers), ASCE (American Society of Civil Engineers), AIME (American Institute of Mining and Metallurgical Engineers), ASTM (American Society for Testing Materials), dentre outros e seu principal objetivo foi o de apoiar e padronizar o trabalho de seus membros, bem como o de elaborar normativas próprias visando a melhoria da qualidade de vida e dos negócios nos Estados Unidos $^{(61)}$.

API (American Petroleum Institute) iniciou suas atividades durante a primeira guerra mundial, quando a indústria de petróleo americana e o congresso se uniram para ajudar nos esforços de guerra. A indústria de maneira geral não tinha experiência neste segmento, mas concordou em trabalhar em conjunto com os órgãos governamentais para garantir o suprimento de petróleo vital às forças armadas. Atualmente o API mantém mais de 500 normas técnicas e recomendações práticas para a indústria de petróleo e gás visando a segurança, a intercambiabilidade de equipamentos e a utilização de práticas de engenharia comprovadas ${ }^{(62)}$.

As normas API são mais voltadas às unidades de produção terrestres, unidades de refino e de transporte, a indústria de petróleo utiliza as normas Norsok como referência para as unidades de produção marítimas em complemento às demais normas.

NORSOK (Norsk Sokkels Konkuranseposisjon), suas normas foram desenvolvidas pela indústria norueguesa de petróleo para garantir segurança adequada, diminuir custos e agregar valor às operações e o desenvolvimento desta indústria. Adicionalmente a Norsok, tanto quanto possível, pretendeu substituir especificações das companhias de petróleo e também servir como referência para a legislação. Suas normas são baseadas em renomadas normas internacionais, acrescentando 
informações onde necessárias para atender as demandas da indústria norueguesa de petróleo e foram preparadas e publicadas com o apoio da indústria norueguesa de petróleo, federação norueguesa da indústria, associação norueguesa de armadores e da autoridade norueguesa para segurança em petróleo. A norma Norsok M-601, base deste trabalho, foi desenvolvida para fornecer requisitos adicionais, observando a soldagem e a inspeção, para os sistemas de tubulação para produção e processamento de hidrocarbonetos projetados conforme a norma ASME B31.3 $3^{(63)}$. 


\section{MATERIAIS E MÉTODOS}

\subsection{MATERIAIS}

Para realização deste trabalho foram utilizados aços inoxidáveis superduplex UNS S32750 com $\mathrm{PRE}_{\mathrm{N}}=43$ e UNS $\mathrm{S} 32760$ com PRE $\mathrm{W}_{\mathrm{W}}$ 42, comerciais, na forma de chapas de 300 x 200 e com 6 mm de espessura, com composições químicas distintas apresentadas na tabela 4.1, e suas respectivas propriedades mecânicas apresentadas na tabela 4.2. Os consumíveis utilizados foram o T2594NLPM2212, próprio para a soldagem dos aços inoxidáveis superduplex UNS $\$ 32750$ e o TS2594FM211 próprio para a soldagem dos aços inoxidáveis superduplex UNS S32760, as denominações estão conforme as normas EN ISO 17633-A e BS EN ISSO 17633-B, respectivamente e suas composições químicas estão apresentadas na tabela 4.3.

Tabela 4.1: Quadro comparativo das composições químicas dos aços inoxidáveis superduplex UNS S32750 e UNS S32760 conforme recebidos.

\begin{tabular}{|c|c|c|c|c|c|c|c|c|c|c|c|}
\hline Material & $\% \mathbf{C}$ & $\% \mathbf{C r}$ & $\% \mathbf{N i}$ & $\% \mathbf{S i}$ & $\% \mathbf{P}$ & $\% \mathbf{S}$ & $\% \mathbf{M n}$ & $\% \mathbf{M o}$ & $\% \mathbf{N}$ & $\% \mathbf{C u}$ & $\% \mathbf{W}$ \\
\hline UNS S32750 & 0,024 & 24,873 & 6,719 & 0,294 & 0,024 & 0,001 & 0,765 & 3,605 & 0,252 & -- & -- \\
\hline UNS S32760 & 0,024 & 24,704 & 6,611 & 0,289 & 0,023 & 0,001 & 0,760 & 3,616 & 0,25 & 0,665 & 0,745 \\
\hline
\end{tabular}

Tabela 4.2: Quadro comparativo das propriedades mecânicas dos aços inoxidáveis superduplex UNS S32750 e UNS S32760 conforme recebidos.

\begin{tabular}{|c|c|c|c|c|}
\hline Material & $\begin{array}{c}\text { Limite de Escoamento } \\
(\mathbf{M P a})\end{array}$ & $\begin{array}{c}\text { Limite de } \\
\text { Resistência } \\
\text { (MPa) }\end{array}$ & $\begin{array}{c}\text { Alongamento } \\
(\%)\end{array}$ & $\begin{array}{c}\text { Impacto } \\
\text { (Charpy-V) } \\
\mathbf{a}-46{ }^{\circ} \mathbf{C}(\mathbf{J})\end{array}$ \\
\hline UNS S32750 & 719 & 928 & 35 & $143,3 \pm 11,3$ \\
\hline UNS S32760 & 659 & 874 & 36 & $170,0 \pm 1,4$ \\
\hline
\end{tabular}

Tabela 4.3: Quadro comparativo das composições químicas dos consumíveis de soldagem T2594NLPM2212 e TS2594FM211, informado pelo fabricante.

\begin{tabular}{|c|c|c|c|c|c|c|c|c|c|c|c|}
\hline Material & $\% \mathbf{C}$ & $\% \mathbf{C r}$ & $\% \mathbf{N i}$ & $\% \mathbf{S i}$ & $\% \mathbf{P}$ & $\% \mathbf{S}$ & $\% \mathbf{M n}$ & $\% \mathbf{M o}$ & $\% \mathbf{N}$ & $\% \mathbf{C u}$ & $\% \mathbf{W}$ \\
\hline \multirow{2}{*}{ T2594NLPM2212 } & até & 24 & 8,5 & até & até & até & 0,5 & 3,5 & 0,2 & até & -- \\
& 0,04 & 26 & 10,5 & 1 & 0,03 & 0,02 & 2 & 4,5 & 0,3 & 0,5 & -- \\
\hline \multirow{2}{*}{ TS2594FM211 } & até & 24 & 9 & até & até & até & até & 3,5 & 0,2 & 0,5 & 0,5 \\
& 0,03 & 26 & 10,5 & 1 & 0,03 & 0,01 & 1 & 4 & 0,3 & 1 & 1 \\
\hline
\end{tabular}




\subsection{MÉTODOS}

\subsubsection{PREPARAÇÃO DAS CHAPAS}

$\mathrm{Na}$ preparação dos corpos de prova foram usinados chanfros com $30^{\circ} \mathrm{em}$ metade das chapas, e mantido o acabamento reto na outra metade das chapas, desta forma obtendo chanfros do tipo meio " $\mathrm{V}$ " conforme figura 4.1, esta configuração foi idealizada com o intuito de analisar a repartição térmica, tanto nos planos horizontais, superior e inferior, quanto no plano vertical.

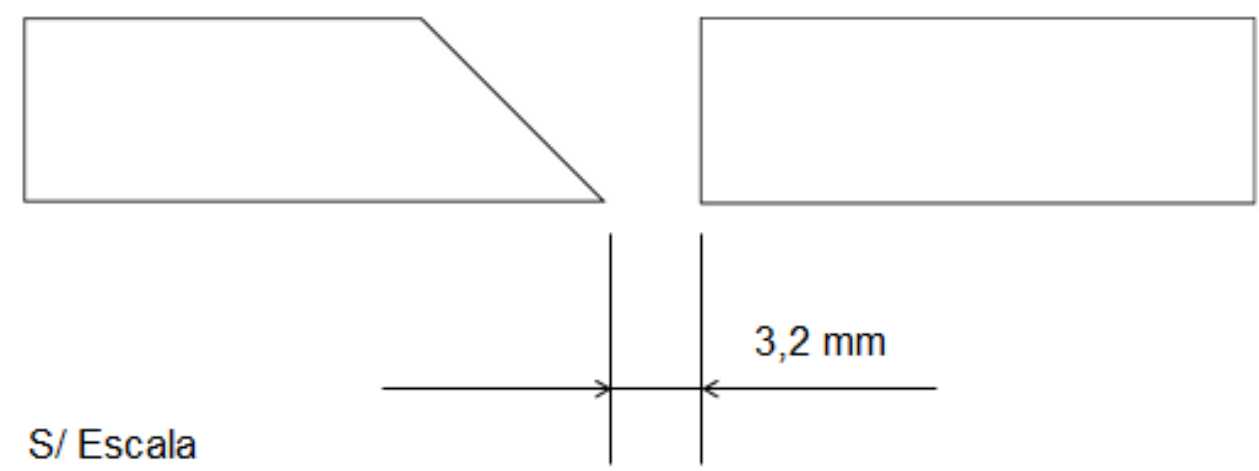

Figura 4.1: Chanfros de acabamento para soldagem dos corpos de prova em aço inoxidável superduplex UNS S32750 e UNS S32760.

\subsubsection{SOLDAGEM DE TESTE}

Para ajuste do equipamento foi feita soldagem de teste em corpos de prova dos aços inoxidáveis superduplex UNS S32750 e UNS S32760 por meio do processo de soldagem com arame tubular - MCAW (Metal Cored Arc Welding) automatizado, na posição horizontal (1G), onde foi utilizado o equipamento Fanuc - Arc Mate 50 ic e os melhores resultados foram obtidos com espaçamento de junta de $2 \mathrm{~mm}$, velocidade de soldagem de $6,35 \mathrm{~mm} / \mathrm{s}$, velocidade de alimentação do consumível de $135 \mathrm{~mm} / \mathrm{s}$, tensão de 25,0 V, corrente de 150,0 A resultando em uma energia de soldagem de $0,53 \mathrm{~kJ} / \mathrm{mm}$, este valor foi adotado por se tratar de um valor intermediário entre os limites estabelecidos pela norma ISO/TR 17.671-3 de 2002, foi utilizado o consumível ER329N da Metrode Welding Consumables com diâmetro 
de 1,2 mm, item MER329M-10 classe AWS A5.9M/ER2209 e ASME SFA 5.9/ER2209 proveniente do lote U2MG132583 e foram necessários dois passes, sendo o primeiro para raiz e o segundo para fechamento.

\subsubsection{SOLDAGEM DOS CORPOS DE PROVA}

A soldagem dos corpos de prova foi executada por meio do processo de soldagem com arame tubular - MCAW (Metal Cored Arc Welding) automatizado, na posição horizontal $(1 \mathrm{G})$, com o mesmo equipamento utilizado na soldagem de teste, com velocidade de soldagem de $6,35 \mathrm{~mm} / \mathrm{s}$, velocidade de alimentação do consumível de $135 \mathrm{~mm} / \mathrm{s}$, tensão média de 24,6 $\pm 1,1 \mathrm{~V}$, corrente média de 150,2 $\pm 17,0 \mathrm{~A}$, resultando em uma energia de soldagem média de 0,53 \pm 0,07 kJ/mm, com atmosfera de proteção suplementar 80-20 (80\% de $\operatorname{Ar}$ e 20\% e CO $\mathrm{CO}_{2}$ ), a escolha deste gás se deu por ser inerte e não acrescentar elementos de liga ao metal de solda e também por ser amplamente utilizado pela indústria na soldagem destes aços, foi utilizado cobre junta cerâmico na parte inferior das chapas, e os consumíveis utilizados foram T2594NLPM2212 e TS2594FM211, ambos do mesmo fornecedor, com diâmetro de 1,2 mm, e foram necessários dois passes, sendo o primeiro para a raiz e o segundo para o fechamento. Foram soldados oito corpos de prova, inicialmente com os materiais similares, um corpo de prova para cada, com seus respectivos consumíveis e posteriormente foi feita a soldagem dissimilar alternando os consumíveis, três corpos de prova para cada tipo, o esquema de soldagem está representado na figura 4.2. A energia de soldagem obtida para cada um dos corpos de prova dos aços inoxidáveis super duplex UNS S32750 e UNS S32760 está dentro do intervalo de 0,2 a 1,5 kJ/mm conforme estabelecido na norma ISO/TR 17671-3 para soldagem de aços inoxidáveis superduplex. 

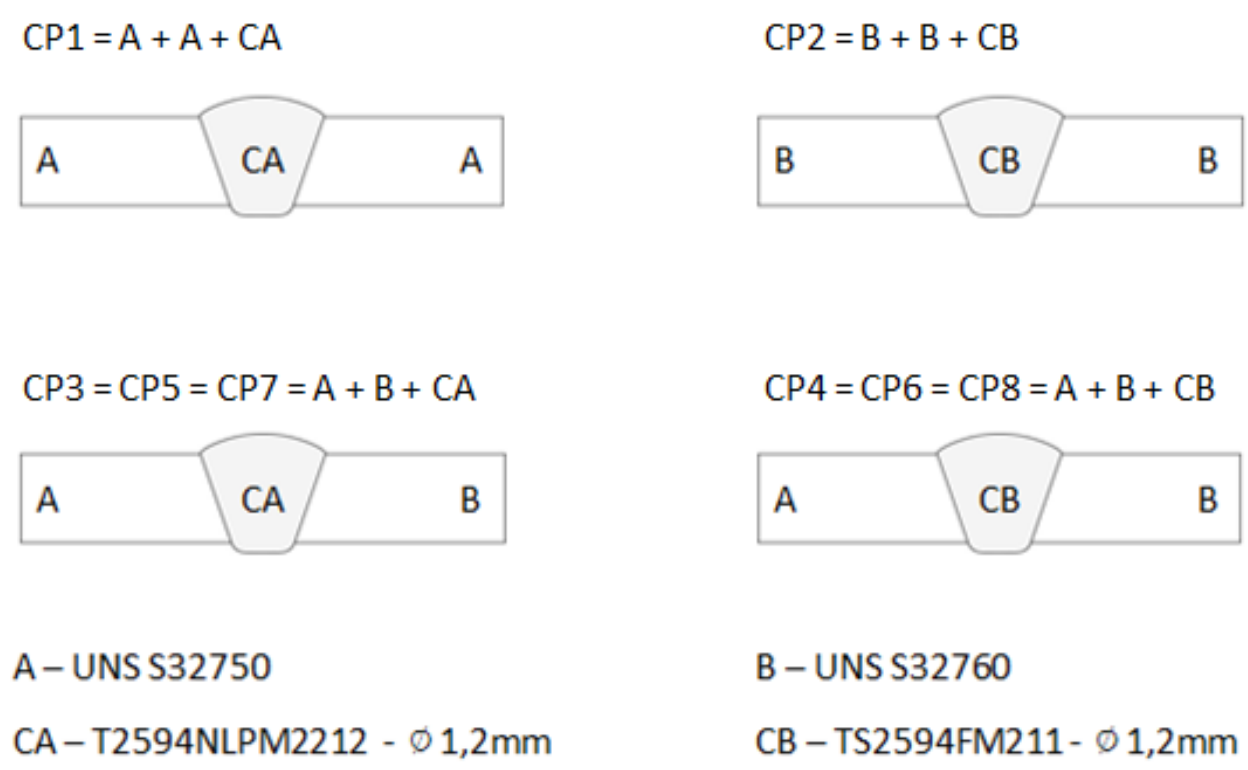

B - UNS $\$ 32760$

CB - TS2594FM211 - $\emptyset 1,2 \mathrm{~mm}$

Figura 4.2: Esquema dos corpos de prova, sendo o que A é o metal de base UNS S32750, B é o metal de base UNS S32760, CA é o consumível T2594NLPM2212 e o CB é o consumível TS2564FM211.

\subsubsection{CICLOS TÉRMICOS}

Foram instalados 6 termopares ao longo dos corpos de prova nas regiões inferiores, aproximadamente a $0,5 \mathrm{~mm}$ um do outro a partir do vão, para obtenção da variação das temperaturas durante a soldagem, desta forma obtendo-se os ciclos térmicos da soldagem e também a sua repartição térmica, figura 4.3.

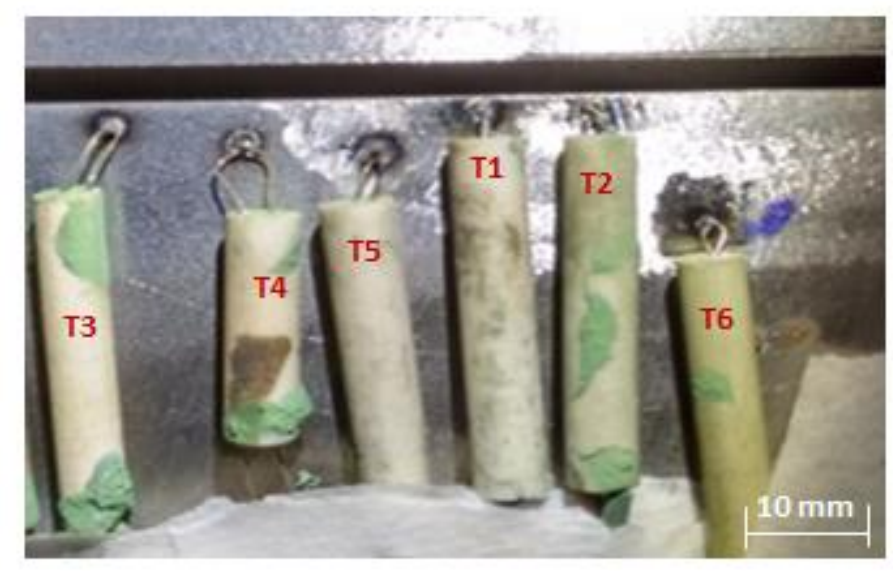

Figura 4.3: Localização dos termopares a partir da abertura, T1 a 0,5 mm, T2 a 1,0 mm, T3 a 1,5 mm, T4 a 2,0 mm, T5 a 3,0 mm e T6 a 5,0 mm. 


\subsection{CARACTERIZAÇÃO MICROESTRUTURAL}

\subsubsection{CARACTERIZAÇÃO MICROESTRUTURAL - MICROSCOPIA ÓTICA}

Para realização do exame microestrutural as amostras retiradas dos corpos de prova foram embutidas a quente em baquelite, lixadas e polidas com pasta de diamante de 6 , 3 e $1 \mu \mathrm{m}$ e em seguida receberam polimento fino com suspenção de sílica com partícula média de 0,06 $\mu \mathrm{m}$. Os corpos de prova polidos foram atacados quimicamente, para revelar sua microestrutura, com solução de ácido oxálico a 10\% com método de aplicação eletrolítico com tensão de $6 \mathrm{~V}$ durante 120 segundos. $\mathrm{O}$ metal de base, metal de solda e as zonas afetadas pelo calor (ZAC) dos corpos de prova foram analisados através de microscópio ótico do tipo Olympus BX60M com ampliação de 50X, 100X, 200X, 500X e 1.000X, com o objetivo de identificar fases intermetálicas, precipitados, Carbonetos e Nitretos, a referência para este ensaio foi o item 4.3.6 da Norsok Standard M-601 ed. 2008 e o ASME IX QW-196.1 ed. 2013.

\subsubsection{CARACTERIZAÇÃO MICROESTRUTURAL - MICROSCOPIA ELETRÔNICA DE VARREDURA}

Face às pequenas dimensões das prováveis fases precipitadas e as pequenas frações volumétricas observadas no microscópio ótico, se faz necessária a observação dos corpos de prova com grandes aumentos por meio de microscopia eletrônica de varredura (MEV) e complementada com microanálise química mediante espectrometria por energia dispersiva, Energy Dispersive Spectrometry (EDS), com sistemas acoplados aos microscópios eletrônicos de varredura para identificação dos precipitados e das fases deletérias. A técnica de difração por elétrons retro espalhados, Electron Back Scatter Difraction (EBSD), bem como a técnica de difração por raios $X(D R X)$, não foram aplicadas por não fazerem parte do escopo deste trabalho.

Para a observação dos corpos de prova foi utilizado o microscópio eletrônico de varredura (MEV) CAMBRIDGE STEREOSCAN 240, operando com tensão de 20 
$\mathrm{kV}$ e as amostras analisadas foram previamente embutidas a quente em baquelite, lixadas e polidas com pasta de diamante de 6, 3 e $1 \mu \mathrm{m}$ e em seguida receberam polimento fino com suspenção de sílica com partícula média de 0,06 $\mu \mathrm{m}$. Os corpos de prova polidos foram atacados quimicamente, para revelar sua microestrutura, com solução de ácido oxálico a 10\% com método de aplicação eletrolítico com tensão de $6 \mathrm{~V}$ durante 90 segundos.

\subsubsection{FRAÇÃO VOLUMÉTRICA DA FERRITA}

Para realização da medição da fração volumétrica as amostras utilizadas no exame microestrutural foram novamente lixadas e polidas com pasta de diamante de 6, 3 e $1 \mu \mathrm{m}$ e em seguida receberam polimento fino com suspenção de sílica com partícula média de 0,06 $\mu \mathrm{m}$. Os corpos de prova polidos foram atacados quimicamente, para revelar sua microestrutura com ataque Behara II, com solução de $80 \mathrm{ml}$ água destilada e deionizada, $40 \mathrm{ml}$ de ácido clorídrico, $4,8 \mathrm{~g}$ de fluoreto de amônia e 1,2 $\mathrm{g}$ de metabissulfito de potássio com método de aplicação de imersão durante 8 minutos. O metal de base, metal de solda e as zonas afetadas pelo calor (ZAC) dos corpos de prova foram analisados através de microscópio ótico do tipo Olympus BX60M com ampliação de 200X e 500X e para a determinação da fração volumétrica de ferrita utilizou-se o Software Axio Vision SE64 versão 4.9.1, a referência para este ensaio foi o item 4.3.6 da Norsok Standard M-601 ed. 2008.

\subsection{ENSAIOS NÃO DESTRUTIVOS}

\subsubsection{EXAME VISUAL DAS SOLDAS}

Foi realizado exame visual das juntas soldadas das amostras para verificar penetração total da solda e fusão completa do metal de solda com o metal base, a referência para este ensaio foi o ASME IX QW-194. 


\subsubsection{ENSAIO COM LÍQUIDO PENETRANTE}

Foi realizado o ensaio de Líquido Penetrante nas soldas dos corpos de prova com limpeza da junta utilizando removedor E-59 da Metal Check lote 19755, aplicação do líquido penetrante VP-30 da Metal Check lote 19706 com tempo mínimo de 30 minutos para penetração em possíveis trincas e poros. Decorridos os 30 minutos foi feita a limpeza com o mesmo removedor e posterior aplicação do revelador D-70 da Metal Check lote 19789, este ensaio foi realizado conforme os critérios do ASME IX QW-195.2.2 ed. 2013, que estabelece a metodologia de execução deste ensaio bem como os critérios para avaliação das amostras, que devem estar livres de trincas e de poros externos.

\subsubsection{MEDIÇÃO DA DUREZA}

Com o objetivo de manter as condições dos ensaios o mais próximo possível das práticas utilizadas pela indústria de óleo e gás, não foi feita a medição da dureza na região das soldas bem com nas zonas afetadas pelo calor (ZAC), respeitando os quesitos da norma na qual todo este trabalho está baseado, Norsok Standard M-601 ed. 2008, que em seu item 4.3.4 estabelece que a medição de dureza para os aços inoxidáveis duplex e superduplex não é necessária.

\subsection{ENSAIOS DESTRUTIVOS}

\subsubsection{ENSAIO DE IMPACTO (CHARPY - V)}

Foi realizado o ensaio de impacto do tipo Charpy com entalhe em $\mathrm{V}$ em laboratório com temperatura ambiente constante de $23^{\circ} \mathrm{C}$, os corpos de prova foram mantidos imersos em glicol na temperatura de $-46{ }^{\circ} \mathrm{C}$, os entalhes foram feitos conforme os critérios normativos da ASTM E 23 ed. 2014 e da ASTM 370 ed. 2014, representadas na figura 4.3 e suas dimensões foram verificadas através de um projetor de perfil. O teste de impacto foi aplicado na região das soldas e das zonas afetadas pelo calor (ZAC) no sentido longitudinal à solda, sendo 3 amostras para cada, mais 3 amostras para o metal base do UNS S32750 e mais 3 amostras para o 
metal base do UNS S32760 totalizando 54 amostras, o equipamento utilizado neste ensaio de impacto possui capacidade de 408J.
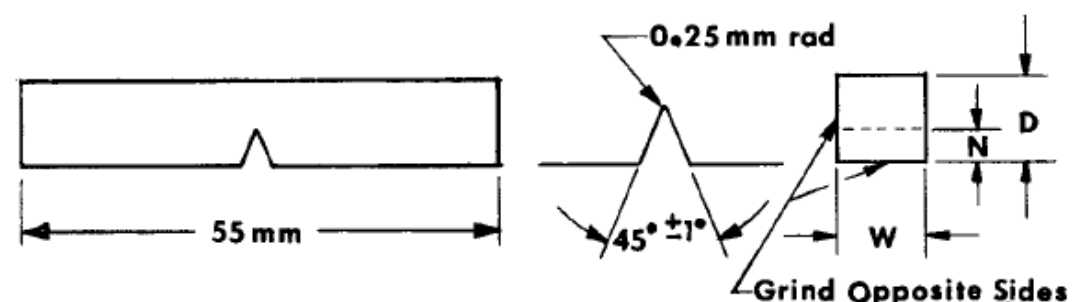

Parallel and $90^{\circ} \pm 10^{\circ}$

to Adjacent Sides

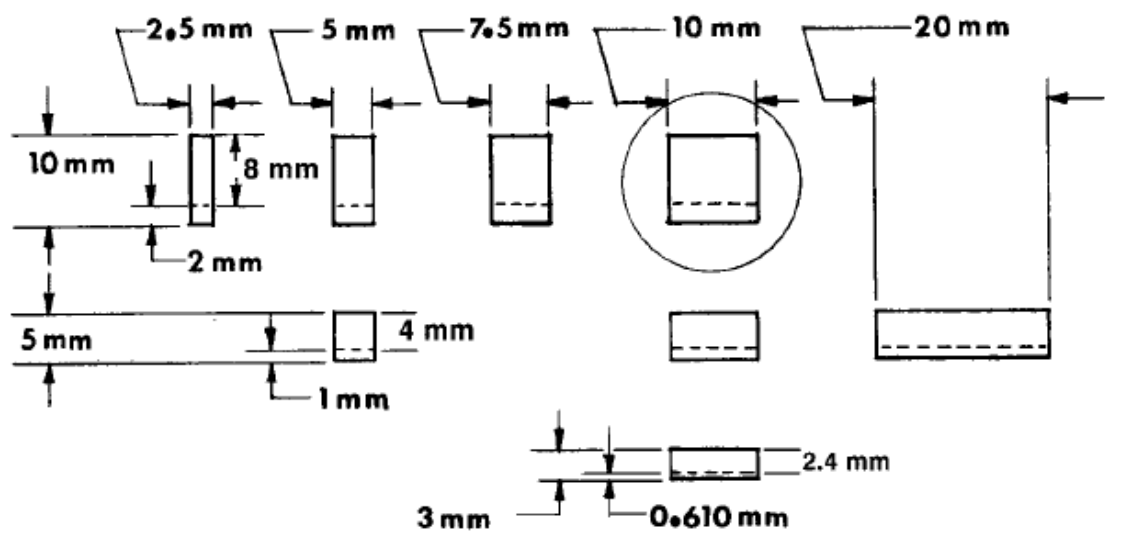

Figura 4.4: Representação do corpo de prova para ensaio de impacto conforme ASTM E23. 




Figura 4.5: Parte dos corpos de prova de seção reduzida para o ensaio de impacto conforme ASTM E23.

\subsubsection{ENSAIO DE TRAÇÃO}

Os corpos de prova foram usinados e preparados conforme os padrões da ASTM 370 ed. 2014 e ASME IX QW-462.1(a), figura 4.6, e suas dimensões conferidas por meio do paquímetro, o ensaio de tração foi realizado em laboratório com temperatura ambiente constante de $23^{\circ} \mathrm{C}$. Os corpos de prova foram submetidos a tração por meio de uma máquina universal de ensaio de tração e foram tracionados até a ruptura e suas as respectivas cargas foram medidas diretamente do equipamento conforme ASME IX QW-150 ed. 2013, com incerteza de medição de \pm $1 \%$ resultando em um nível de confiança de $95 \%$. Os corpos de deverão romper na região do metal base, conforme ASME IX QW-153.

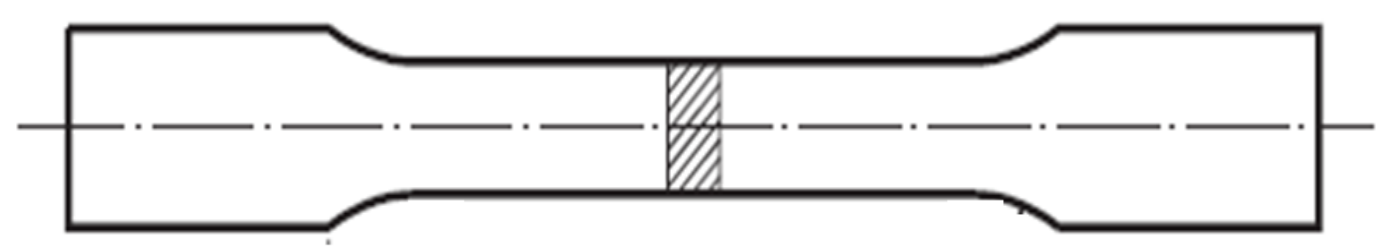

Figura 4.6: Corpo de prova de seção reduzida para ensaio de tração em chapas conforme ASTM 370 ed. 2014 e ASME IX QW-462.1(a) ed. 2015. 


\subsubsection{ENSAIO DE DOBRAMENTO}

Foi realizado ensaio de dobramento a $180^{\circ}$, em laboratório com temperatura ambiente constante de $23{ }^{\circ} \mathrm{C}$, nos corpos de prova soldados para verificar a presença de trincas e ou aberturas na região da face superior das soldas, todos os corpos de prova foram confeccionados com $275 \mathrm{~mm}$ de comprimento, $38 \mathrm{~mm}$ de largura e $6 \mathrm{~mm}$ de espessura. Foi utilizado cutelo com de largura de $25 \mathrm{~mm}$ e raio de 12,5 mm correspondente a 2 vezes a espessura da chapa e distância entre os roletes foi de $40 \mathrm{~mm}$, de acordo com o estabelecido na norma ASME IX QW-466.1 ed. 2013 para aços com alongamento superior a 20\% e espessuras menores que 10 mm, e de acordo com os critérios do ASME IX QW-163 ed. 2013 as trincas e ou aberturas não podem ter dimensões superiores a 3,2 mm em qualquer direção.

\subsubsection{ENSAIOS DE CORROSÃO}

\subsubsection{ENSAIO DE CORROSÃO G-48}

Foi realizado ensaio de corrosão G-48 nos corpos de prova, abrangendo as regiões dos metais de base, das soldas e das zonas afetadas pelo calor (ZAC), conforme item 4.3.5 da Norsok Standard M-601, ASME IX QW-200 e ASME IX QW-300, na temperatura de $40{ }^{\circ} \mathrm{C}$ com tempo mínimo de exposição de 24 horas conforme método $A$, item 8 da norma ASTM G 48, método de teste de resistência a corrosão localizada puntiforme ou alveolar e corrosão por frestas dos aços inoxidáveis duplex, utilizando-se uma solução, de $100 \mathrm{~g}$ de cloreto férrico hexa-hidratado $\left(\mathrm{FeCl}_{3} .6 \mathrm{H}_{2} \mathrm{O}\right)$ com água destilada com $\mathrm{pH}=6$ de acordo com item 6 da norma ASTM G 48, conforme tabela 1 da norma ASTM D 1193 que estabelece que a água deve ter $\mathrm{pH}$ entre 5 e 8 , que resultou em $\mathrm{pH}=3$ da solução do ensaio. As amostras utilizadas neste ensaio não foram embutidas, receberam apenas lixamento com lixa d'água de gramatura 600 e todos os cantos foram arredondados para evitar o efeito de frestas, as amostras foram pesadas antes e depois do ensaio utilizando-se uma balança de precisão. 


\subsubsection{TÉCNICA LOCALIZADA DE SVET}

Adicionalmente ao ensaio de corrosão $\mathrm{G} 48$ foi aplicada a técnica de varredura por eletrodo vibrante, Scanning Vibrating Eletrode Technique (SVET), que é um método não invasivo que permite levantar as intensidades de correntes locais em uma superfície imersa num eletrólito, esta técnica foi aplicada apenas em caráter qualitativo uma vez que não faz parte do escopo deste trabalho. Para realização deste ensaio a solução utilizada foi de $3,5 \% \mathrm{NaCl}$ em massa acidificada com $\mathrm{HCl}$ e com $\mathrm{pH}=2$, as amostras foram embutidas a quente em baquelite, lixadas e polidas com pasta de diamante de 6 , 3 e $1 \mu \mathrm{m}$ e em seguida receberam polimento fino com suspenção de sílica com partícula média de $0,06 \mu \mathrm{m}^{(66)}$.

Esta técnica baseia-se na medição das pequenas variações de potencial devidas ao fluxo de correntes iônicas provocadas pelas reações que ocorrem na superfície em corrosão e obtendo-se o campo elétrico ou, pela lei de Ohm, as densidades das correntes iônicas locais à medida que o elétrodo vibrante faz a varredura num plano paralelo à superfície da amostra. Os valores medidos são função da distribuição destas correntes iônicas características dos processos que ocorrem na superfície. A técnica posteriormente considera a superfície da amostra como sendo constituída por uma malha de quadrados no centro dos quais existe um ponto por onde emerge ou imerge uma corrente eléctrica. Utilizando-se esta técnica pode-se medir gradientes de tensão até aos níveis de nV (nano Volts) com tempo de $50 \mathrm{~ms}$ por ponto varrido. Os gradientes de tensão não são distribuídos pela vibração da sonda, que vaiaria de $200 \mathrm{~Hz}$ a $1 \mathrm{kHz}$. O dispositivo que vibra em duas direções é complementado por uma almofada piezoelétrica sensível ao fluxo de elétrons da superfície da peça e os sinais captados são amplificados ${ }^{(66)}$. 


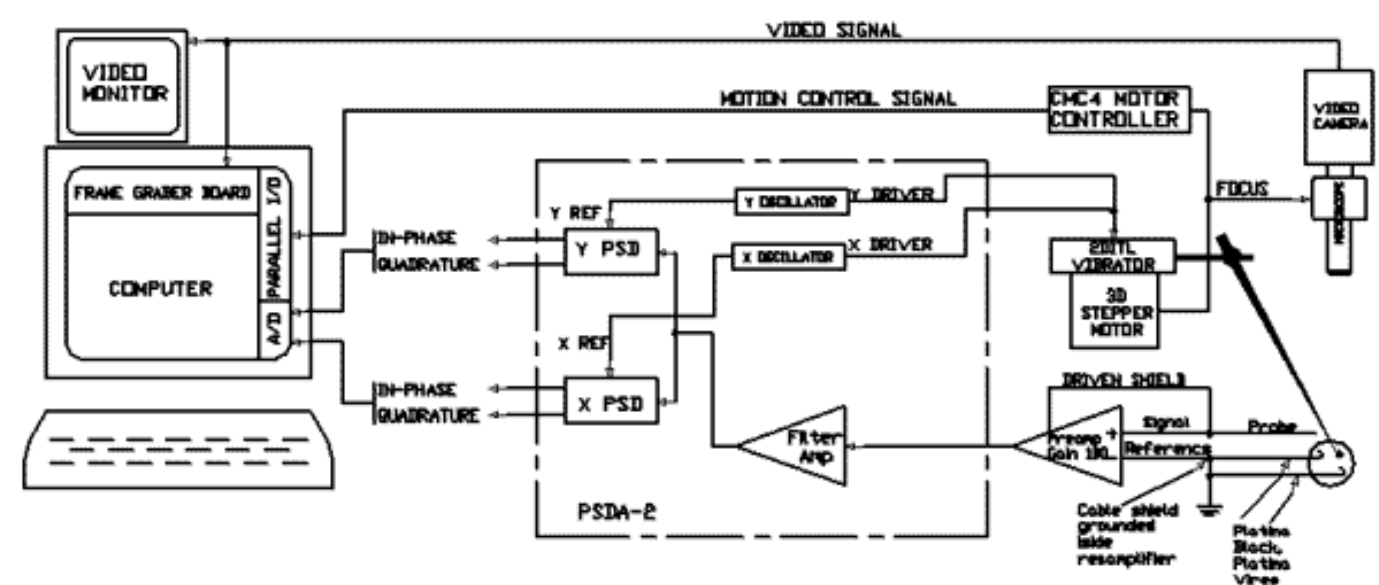

Figura 4.7: Representação esquemática dos equipamentos utilizados para realização do ensaio SVET ${ }^{(66)}$.

Na movimentação da sonda utiliza-se um controle computadorizado de movimento e este sistema de controle de mobilidade foi desenvolvido para utilização em conjunto com sistemas de medição e um Software específico para esta aplicação, para gerar pulsos e sinais direcionados que são enviados a um dispositivo, módulo, que permite comunicar-se através de uma porta paralela. $O$ dispositivo converte os pulsos e direções em sinais que comandam os motores de movimentação no micro posicionador em três eixos, o dispositivo possui um quarto eixo que pode ser utilizado para acionar o foco de microscópio ou qualquer outro dispositivo ótico ${ }^{(66)}$. 


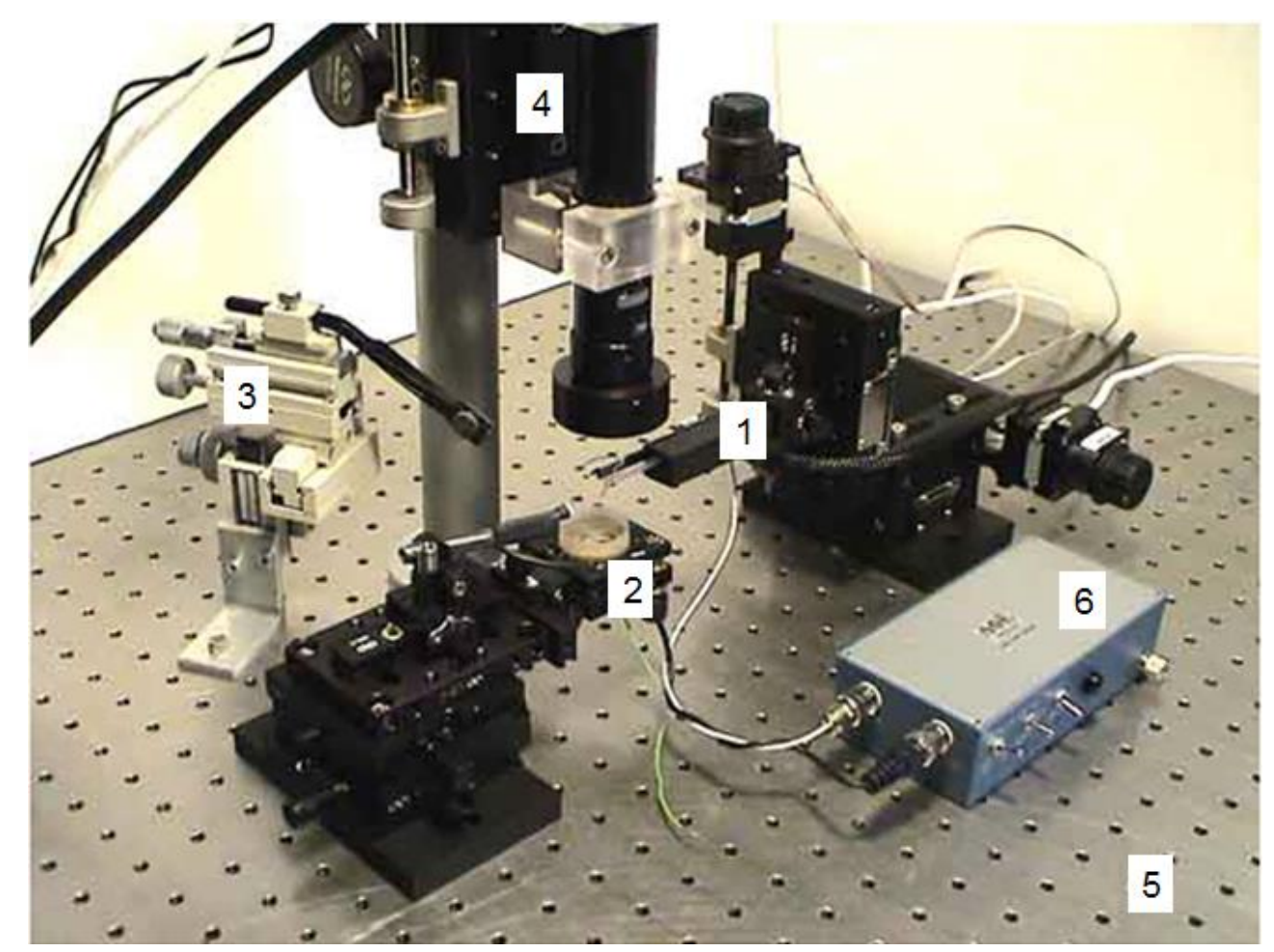

Figura 4.8: Equipamentos utilizados para realização do ensaio SVET, monitor e suporte da sonda (1), porta amostras (2), sonda de calibração (3), suporte do dispositivo ótico (4), mesa suspensa (5) e préamplificador (6).

Para amplificação dos sinais gerados no SVET e pré-amplificados se faz necessário a utilização de um amplificador capaz de medir valores inferiores a $1,0 \mathrm{kHz}$, normalmente de $30 \mathrm{a} 100 \mathrm{~Hz}$. Essencialmente consiste de um poço que permite que um eixo para medição como no SVET e o outro mede a varredura localizada da espectroscopia de impedância eletroquímica Scanning Localized Electrochemical Impedance Spectroscopy (SLEIS) simultaneamente enquanto a sonda faz a varredura da amostra controlada pelo potenciômetro. Esse método de medição proporciona alta sensitividade e a resolução espacial está limitada pelo tipo do eletrodo, normalmente com diâmetros de 5 a $50 \mu \mathrm{m}^{(66)}$. 


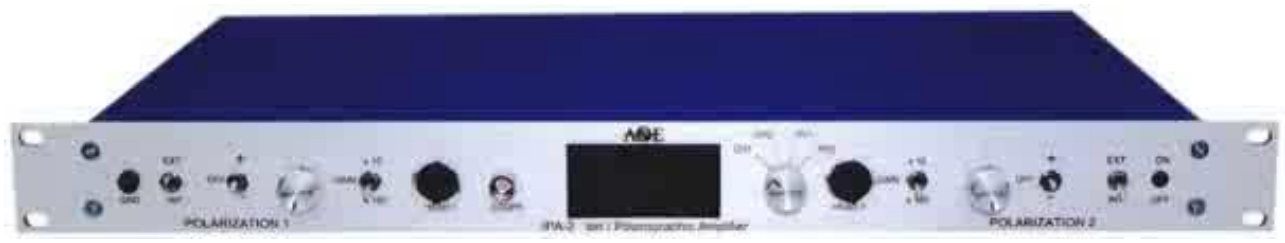

Figura 4.9: Amplificador IPA - 2 Íon/Polarografic utilizado para realização do ensaio SVET.

Finalmente os resultados são apresentados de forma gráfica com a utilização de um Software denominado QUIKGRID, que faz a leitura de um conjunto de dados dispersos em três direções $(x, y, z)$ e que representam uma superfície, o programa gera uma grade a partir destes dados e representa a superfície como um mapa de contornos ou como uma imagem em três dimensões, podendo representar mais de 15.000 pontos em uma grade de $200 \times 200^{(66)}$. 


\section{RESULTADOS}

\subsection{SOLDAGEM}

Foram obtidos oito conjuntos soldados, sendo um conjunto de UNS S32750 com UNS S32750 utilizando-se o consumível T2594NLPM2212, um conjunto de UNS S32760 com UNS S32760 utilizando-se o consumível TS2594FM211, três conjuntos de UNS S32750 com UNS S32760 utilizando-se o consumível T2594NLPM2212 e três conjuntos de UNS S32750 com UNS S32760 utilizando-se o consumível TS2594FM211. A figura 5.1 mostra um corpo-de-prova soldado.



Figura 5.1: Junta soldada dos corpos de prova aço inoxidável superduplex UNS S32750 e UNS S32760.

Durante a soldagem os valores de tensão e de corrente foram medidos diretamente no equipamento por meio de dispositivo de aquisição de dados e obteve-se tensão média de 26,4 $\pm 1,1 \mathrm{~V}$, variação de 4,3\%, corrente média de 150,2 $\pm 17,0 \mathrm{~A}$, variação de $11,3 \%$ e energia de soldagem média de $0,53 \pm 0,02 \mathrm{~kJ} / \mathrm{mm}$, variação de $14,1 \%$. Apesar da variação todos os valores de energia de soldagem estão dentro do intervalo normativo de 0,2 a $1,5 \mathrm{~kJ} / \mathrm{mm}$ e os resultados dos parâmetros de soldagem estão apresentados na tabela 5.1 . 
Tabela 5.1: Quadro dos parâmetros de soldagem dos corpos de prova

\begin{tabular}{|c|c|c|c|c|c|c|c|}
\hline Corpos & Chapa 1 & Chapa2 & Passe & Consumível & $\begin{array}{c}\text { Tensão } \\
\text { (V) }\end{array}$ & $\begin{array}{c}\text { Corrente } \\
\text { (A) }\end{array}$ & $\begin{array}{c}\text { Energia de } \\
\text { soldagem } \\
(\mathrm{kJ} / \mathrm{mm})\end{array}$ \\
\hline CP1 & UNS S32750 & UNS S32750 & 10 & T2594NLPM2212 & 24,2 & 148,8 & 0,51 \\
\hline CP1 & UNS S32750 & UNS S32750 & $2^{\circ}$ & T2594NLPM2212 & 22,9 & 112,6 & 0,37 \\
\hline CP2 & UNS S32760 & UNS S32760 & $1^{\circ}$ & TS2594FM211 & 24,8 & 184,9 & 0,65 \\
\hline CP2 & UNS S32760 & UNS S32760 & $2^{0}$ & TS2594FM211 & 24,6 & 144,0 & 0,50 \\
\hline CP3 & UNS S32750 & UNS S32760 & 10 & T2594NLPM2212 & 23,1 & 151,1 & 0,49 \\
\hline CP3 & UNS S32750 & UNS S32760 & $2^{\circ}$ & T2594NLPM2212 & 22,6 & 132,7 & 0,43 \\
\hline CP4 & UNS S32750 & UNS S32760 & 10 & TS2594FM211 & 26,9 & 169,5 & 0,65 \\
\hline CP4 & UNS S32750 & UNS S32760 & $2^{0}$ & TS2594FM211 & 25,4 & 138,8 & 0,50 \\
\hline CP5 & UNS S32750 & UNS S32760 & 10 & T2594NLPM2212 & 24,9 & 155,6 & 0,55 \\
\hline CP5 & UNS S32750 & UNS S32760 & $2^{\circ}$ & T2594NLPM2212 & 24,9 & 141,1 & 0,50 \\
\hline CP6 & UNS S32750 & UNS S32760 & $1^{0}$ & TS2594FM211 & 25,1 & 174,3 & 0,62 \\
\hline CP6 & UNS S32750 & UNS S32760 & $2^{0}$ & TS2594FM211 & 24,8 & 140,6 & 0,49 \\
\hline CP7 & UNS S32750 & UNS S32760 & 10 & T2594NLPM2212 & 25,3 & 158,4 & 0,57 \\
\hline CP7 & UNS S32750 & UNS S32760 & $2^{\circ}$ & T2594NLPM2212 & 24,8 & 147,6 & 0,52 \\
\hline CP8 & UNS S32750 & UNS S32760 & 10 & TS2594FM211 & 25,2 & 154,3 & 0,55 \\
\hline CP8 & UNS S32750 & UNS S32760 & $2^{\circ}$ & TS2594FM211 & 24,1 & 148,7 & 0,51 \\
\hline
\end{tabular}

\subsection{CICLOS TÉRMICOS}

As temperaturas captadas pelo equipamento de aquisição de dados em cada um dos 6 termopares possibilitou levantar os ciclos térmicos das soldagens. $\mathrm{Na}$ soldagem do primeiro passe do CP2 registrou-se a maior temperatura deste trabalho, que chegou a alcançar um valor próximo de $1.300{ }^{\circ} \mathrm{C}$ e foi captada pelo termopar T1 localizado a 0,5 mm da borda do vão entre as chapas. Esta temperatura elevada deveu-se ao elevado valor da corrente elétrica utilizada que foi de 184,9 A, as figuras $5.2,5.3,5.4$ e 5.5 estão apresentados os ciclos térmicos das soldagens do primeiro e segundo passes dos CP1 e CP2 respectivamente. Foi feito o levantamento da taxa de resfriamento entre $1.200^{\circ} \mathrm{C}$ e $800{ }^{\circ} \mathrm{C}$ e os valores estão apresentados na tabela 5.2 . 


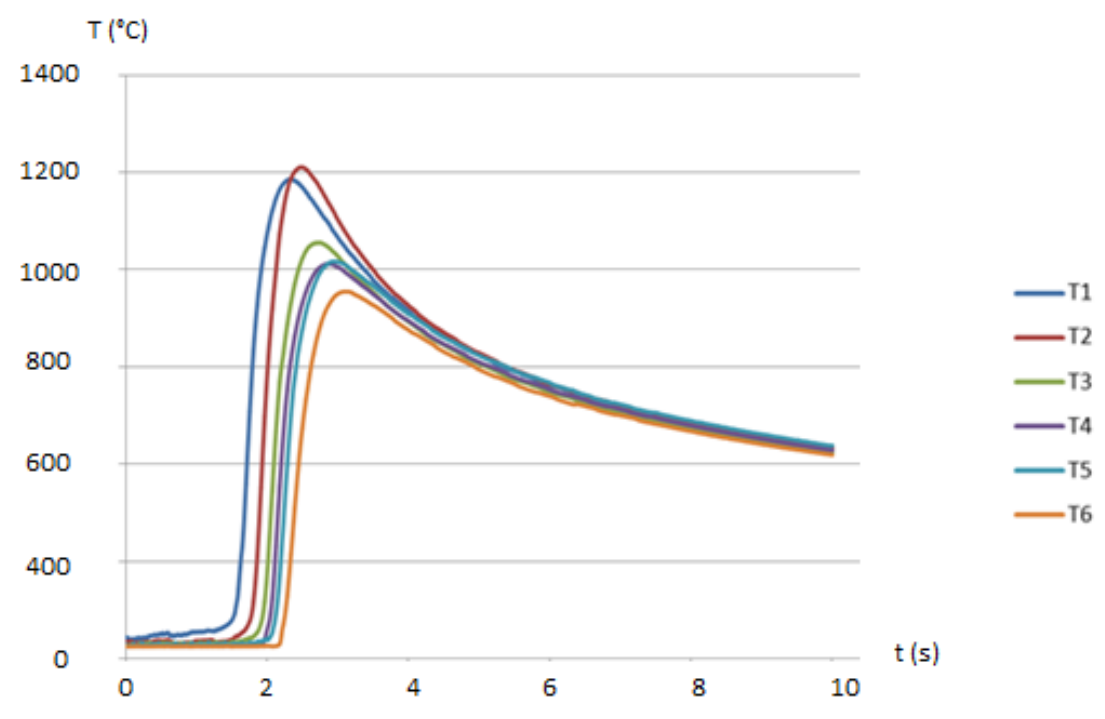

Figura 5.2: Ciclos térmicos da soldagem do CP1 $(A+A+C A)$, UNS S32750, do primeiro passe.

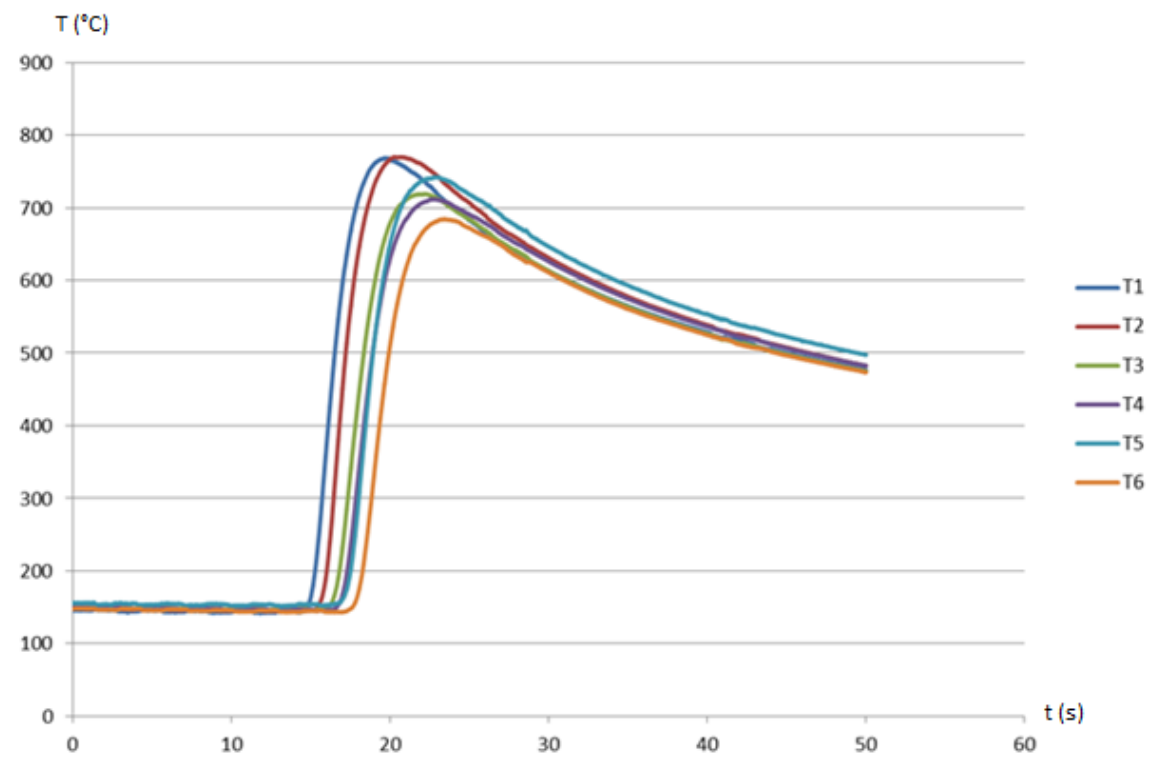

Figura 5.3: Ciclos térmicos da soldagem do CP1 $(A+A+C A)$, UNS S32750, do segundo passe. 


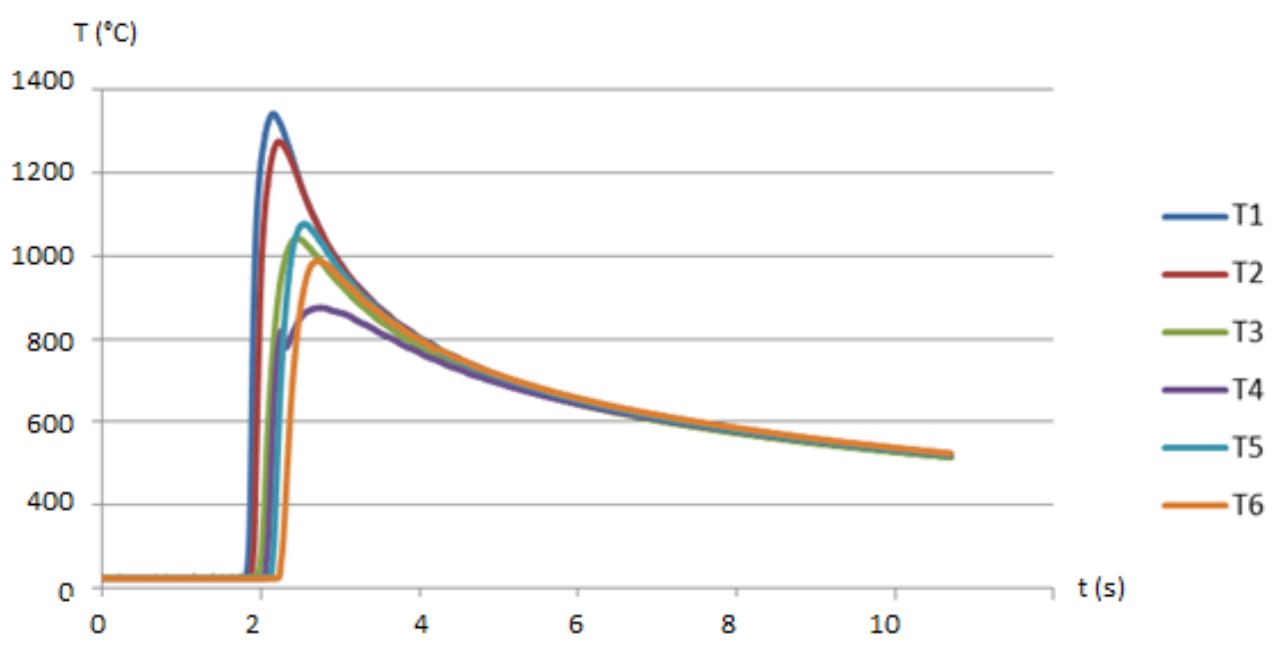

Figura 5.4: Ciclos térmicos da soldagem do CP2 ( $B+B+C B)$, UNS S32760, do primeiro passe.

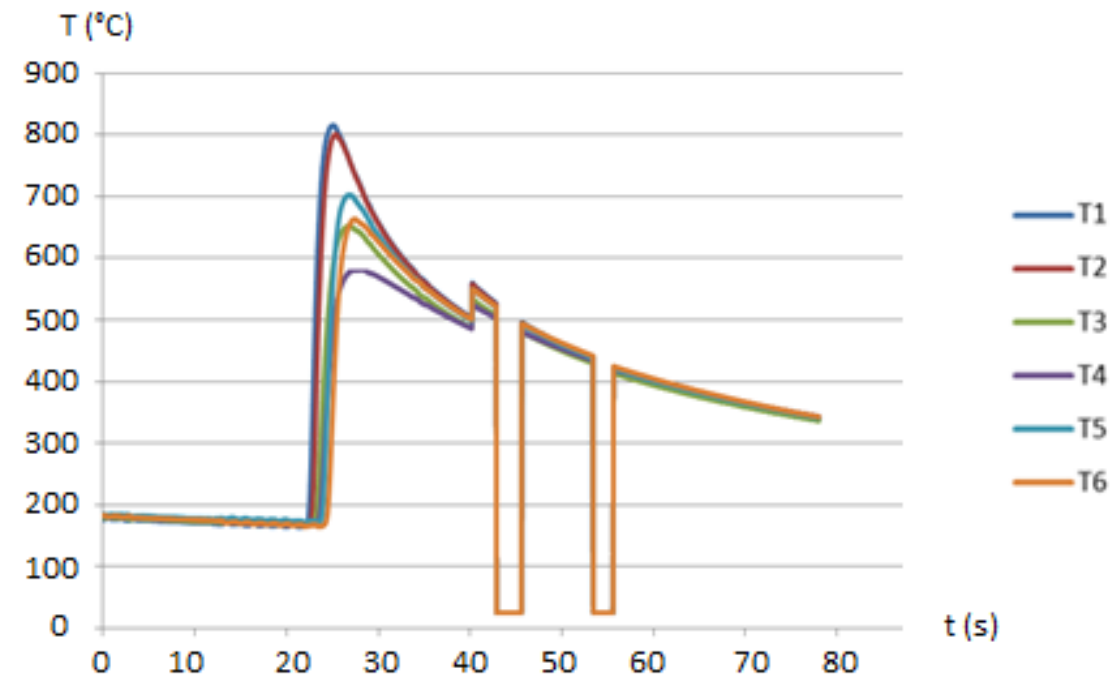

Figura 5.5: Ciclos térmicos da soldagem do CP2 ( $B+B+C B)$, UNS S32760, do segundo passe.

Tabela 5.2: Quadro com os valores da taxa de resfriamento entre $1.200 \stackrel{\circ}{\circ}$ e $800 \stackrel{\circ}{ } \mathrm{C}\left(\Delta \mathrm{t}_{12-8}\right)$.

\begin{tabular}{|c|c|c|c|}
\hline Corpos & Referência & $\boldsymbol{\Delta t}_{\mathbf{1 2 - 8}} \mathbf{( s )}$ & Taxa Resf. $\left({ }^{\circ} \mathbf{C} / \mathbf{s}\right)$ \\
\hline CP1 & A+A+CA & 2,9 & 137,9 \\
\hline CP2 & B+B+CB & 2,8 & 142,9 \\
\hline CP3 & A+B+CA & 3,1 & 129,0 \\
\hline CP4 & A+B+CB & 3,2 & 125,0 \\
\hline CP5 & A+B+CA & 2,9 & 137,9 \\
\hline CP6 & A+B+CB & 3,1 & 129,0 \\
\hline CP7 & A+B+CA & 3,2 & 125,0 \\
\hline CP8 & A+B+CB & 3,2 & 125,0 \\
\hline
\end{tabular}




\subsection{CARACTERIZAÇÃO MICROESTRUTURAL}

\subsubsection{MICROSCOPIA ÓTICA}

\subsubsection{METAL BASE}

Os metais de base, aços inoxidáveis superduplex UNS S32750 e UNS S32760, foram caracterizados e as imagens das metalografias, realizadas nos três eixos, estão representadas na forma de um cubo, figuras 5.6 e 5.8 , e com base nas imagens das vistas frontais, laterais e de topo das amostras destes materiais foi feita a medição da espessura das lamelas de ferrita e de austenita que estão apresentadas nas tabelas 5.3 e 5.4 .

Tabela 5.3: Medida das lamelas de ferrita e de austenita do UNS S32750 nos três eixos

\begin{tabular}{|l|c|l|c|}
\hline \multicolumn{2}{|c|}{ Ferrita no UNS S32750 $(\boldsymbol{\mu m})$} & \multicolumn{2}{c|}{ Austenita no UNS S32750 $(\boldsymbol{\mu m})$} \\
\hline Superfície & $34,7 \pm 12,7$ & Superfície & $31,6 \pm 16,21$ \\
\hline Lateral & $10,6 \pm 1,4$ & Lateral & $10,7 \pm 0,7$ \\
\hline Frontal & $10,9 \pm 2,1$ & Frontal & $11,2 \pm 2,1$ \\
\hline
\end{tabular}

Tabela 5.4: Medida das lamelas de ferrita e de austenita do UNS S32760 nos três eixos

\begin{tabular}{|l|r|l|c|}
\hline \multicolumn{2}{|c|}{ Ferrita no UNS S32760 $(\boldsymbol{\mu m})$} & \multicolumn{2}{c|}{ Austenita no UNS S32760 ( $\mathrm{\mu m})$} \\
\hline Superfície & $31,4 \pm 16,3$ & Superfície & $23,4 \pm 16,3$ \\
\hline Lateral & $10,8 \pm 5,65$ & Lateral & $16,4 \pm 0,7$ \\
\hline Frontal & $16,0 \pm 25,4$ & Frontal & $11,2 \pm 2,1$ \\
\hline
\end{tabular}




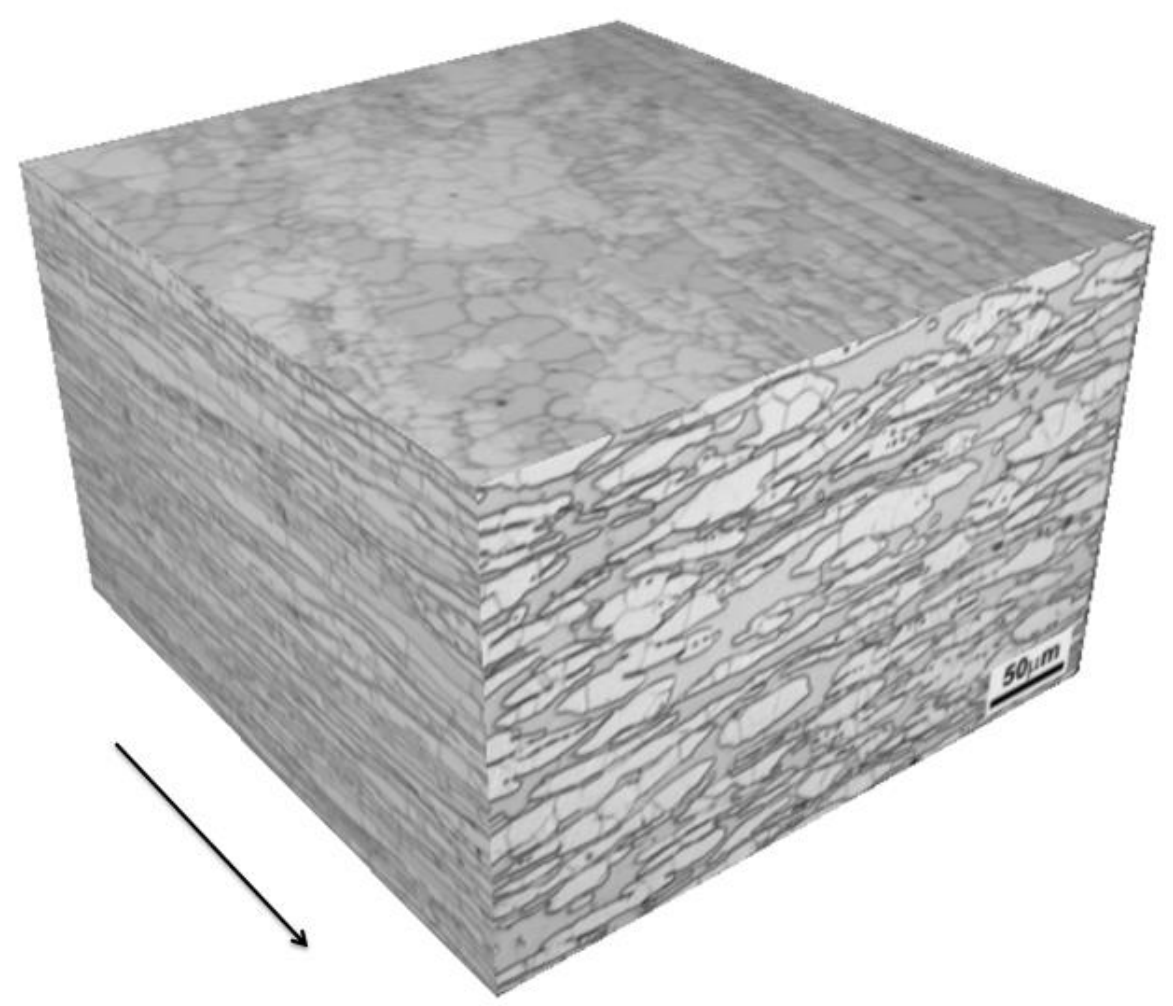

Figura 5.6: Metalografia do aço inoxidável superduplex UNS S32750, a flecha indica o sentido de laminação e a escala apresentada é de $50 \mu \mathrm{m}$.

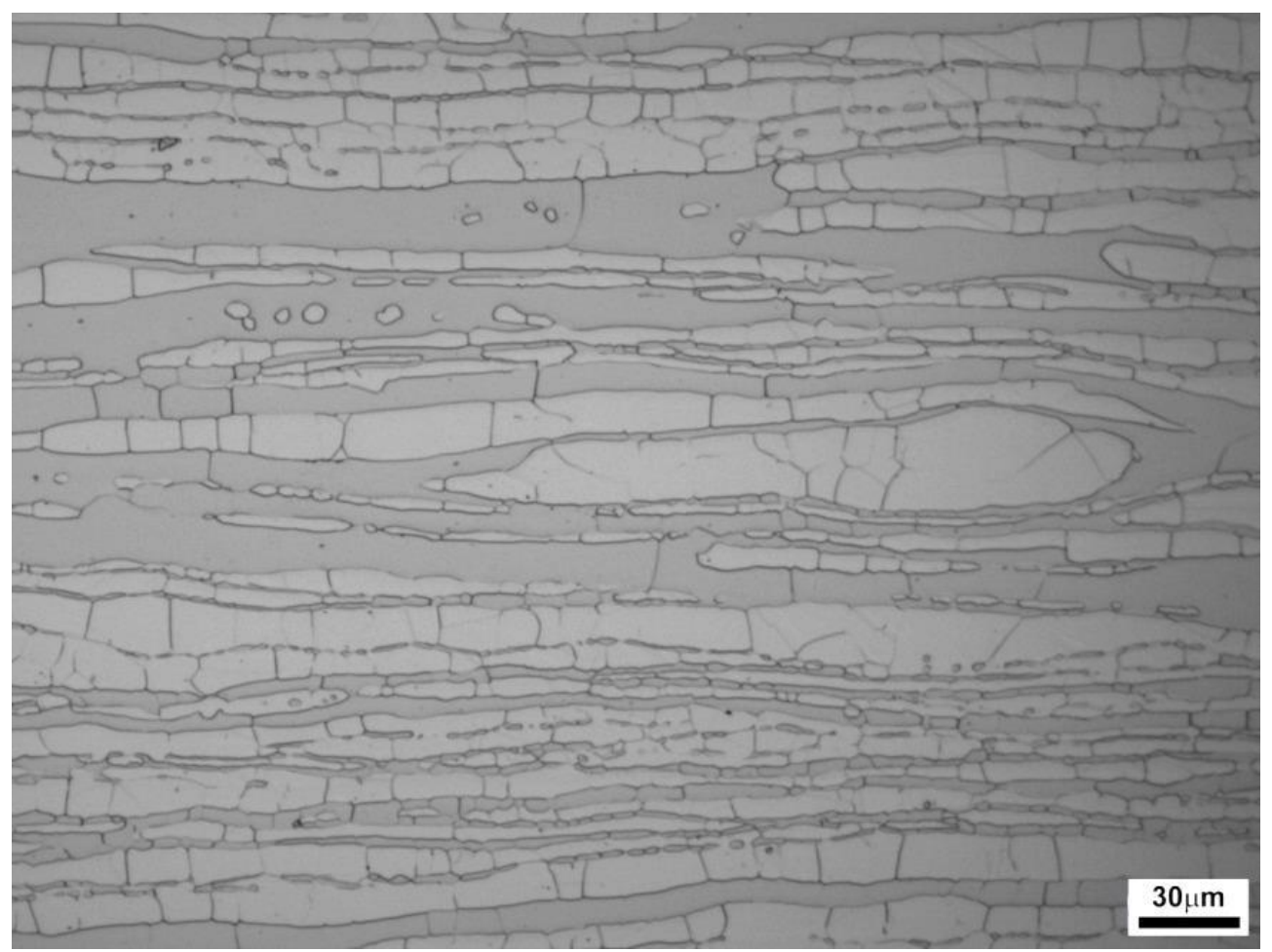

Figura 5.7: Vista frontal com ampliação de 500X do metal de base do UNS S32750 com ataque oxálico. 


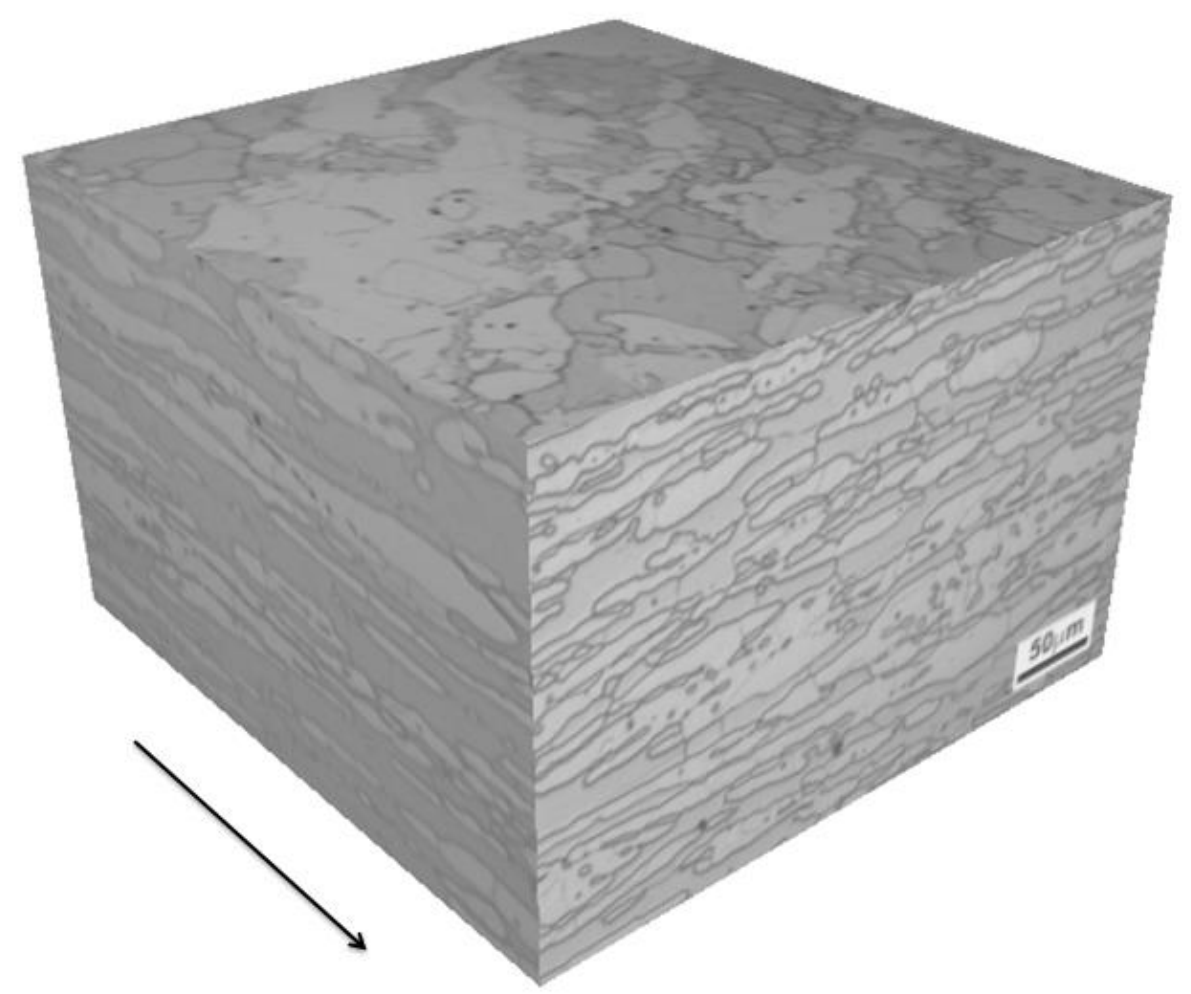

Figura 5.8: Metalografia do aço inoxidável superduplex UNS S32760, a flecha indica o sentido de laminação e a escala apresentada é de $50 \mu \mathrm{m}$.

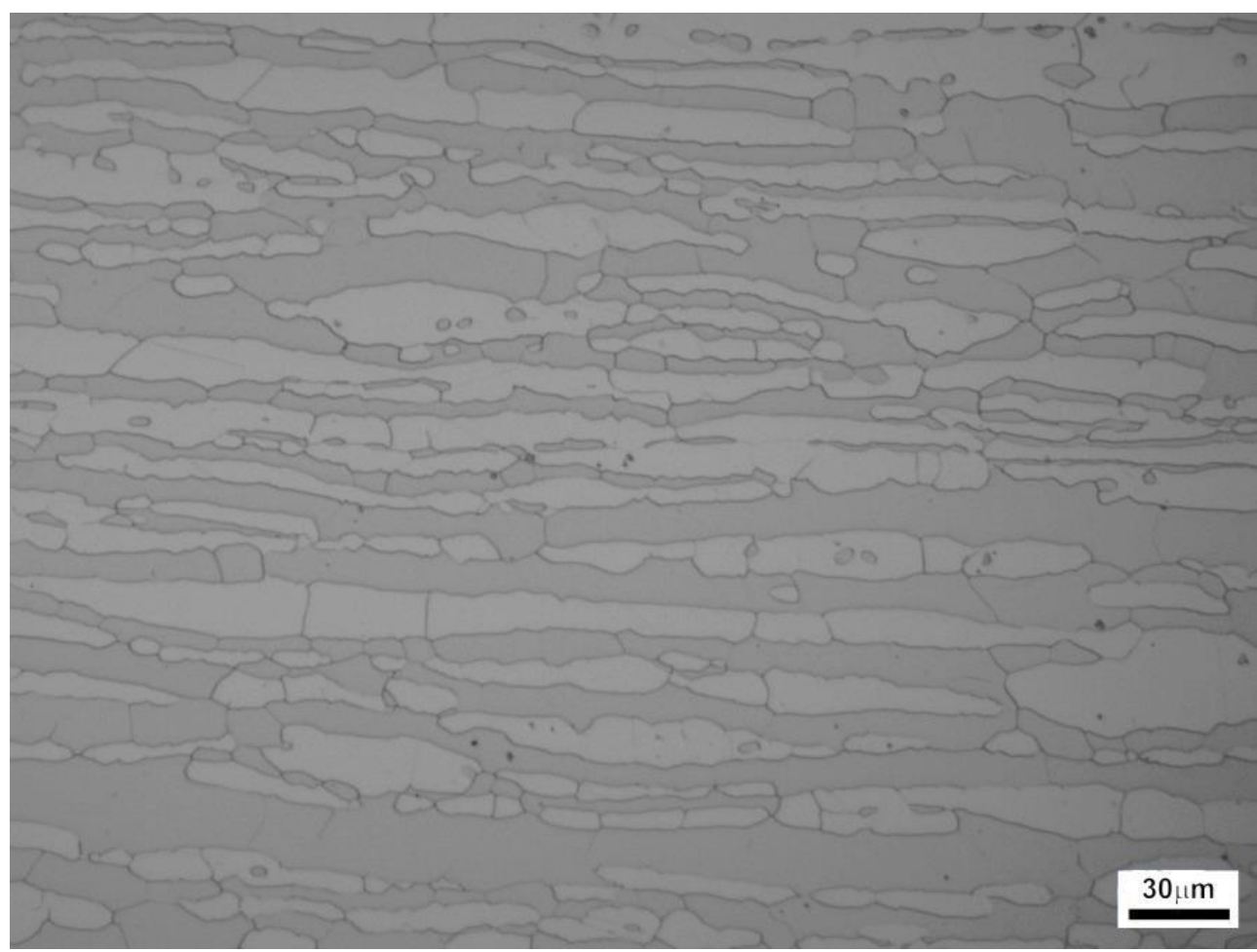

Figura 5.9: Vista frontal com ampliação de 500X do metal de base do UNS S32760 com ataque oxálico. 


\subsubsection{METAL DE SOLDA.}

Foi realizada a análise da composição química dos metais de solda sem diluição, este ensaio foi executado com a utilização de um espectrômetro de emissão ótica em laboratório com temperatura de $25{ }^{\circ} \mathrm{C}$ e umidade relativa de $43 \%$, segundo os critérios de avalição da norma ASTM E 415 ed. 2014 e para a análise dos percentuais de nitrogênio e de oxigênio o ensaio foi via combustão por meio de um analisador de carbono em laboratório com temperatura de $46{ }^{\circ} \mathrm{C}$ e umidade relativa de $26 \%$, e todos os resultados estão apresentados na tabela 5.5. Esta análise se fez necessária uma vez que o fabricante dos consumíveis para soldagem apresenta apenas intervalos para a composição química dos consumíveis, tabela 4.3.

Tabela 5.5: Quadro comparativo das composições químicas dos metais das soldas para o UNS S32750 e para o UNS S32760.

\begin{tabular}{|c|c|c|c|c|c|c|c|c|c|c|}
\hline Metal de solda & $\% \mathbf{C}$ & $\% \mathrm{Cr}$ & $\% \mathrm{Ni}$ & $\% \mathrm{Si}$ & $\% \mathbf{P}$ & $\% \mathbf{S}$ & $\% \mathrm{Mn}$ & $\% \mathrm{Mo}$ & $\% \mathrm{Cu}$ & $\% \mathbf{W}$ \\
\hline T2594NLPM2212 & 0,029 & 24,676 & 8,818 & 0,426 & 0,016 & 0,002 & 0,615 & 3,989 & - & - \\
\hline TS2594FM211 & 0,03 & 24,852 & 8,682 & 0,395 & 0,02 & 0,003 & 0,805 & 3,449 & 0,669 & 0,588 \\
\hline & $\% \mathbf{N}$ & $\% \mathbf{O}$ & $\% \mathrm{Ce}$ & $\% \mathrm{Ti}$ & $\% \mathrm{Al}$ & $\% \mathrm{~V}$ & $\% \mathrm{Nb}$ & - & - & - \\
\hline T2594NLPM2212 & 0,245 & 0,066 & 0,001 & 0,003 & - & - & - & - & - & - \\
\hline TS2594FM211 & 0,277 & 0,0627 & - & 0,004 & 0,017 & 0,06 & 0,013 & - & - & - \\
\hline
\end{tabular}

Foram realizados os exames microestruturais das amostras retiradas dos corpos de prova atacados quimicamente, para revelar sua microestrutura, com solução de ácido oxálico a 10\% com método de aplicação eletrolítico com tensão de 6 V durante 120 segundos, mesmo ataque utilizado na caracterização dos metais de base, e foi observado que em todos os metais de solda há grande quantidade micro inclusão de escória, algo comum no processo de soldagem do tipo arame tubular (MCAW), foi observada também a presença de pequenas porções de austenita secundária e de nitretos nas figuras $5.10,5.11,5.12$ e 5.13 . 


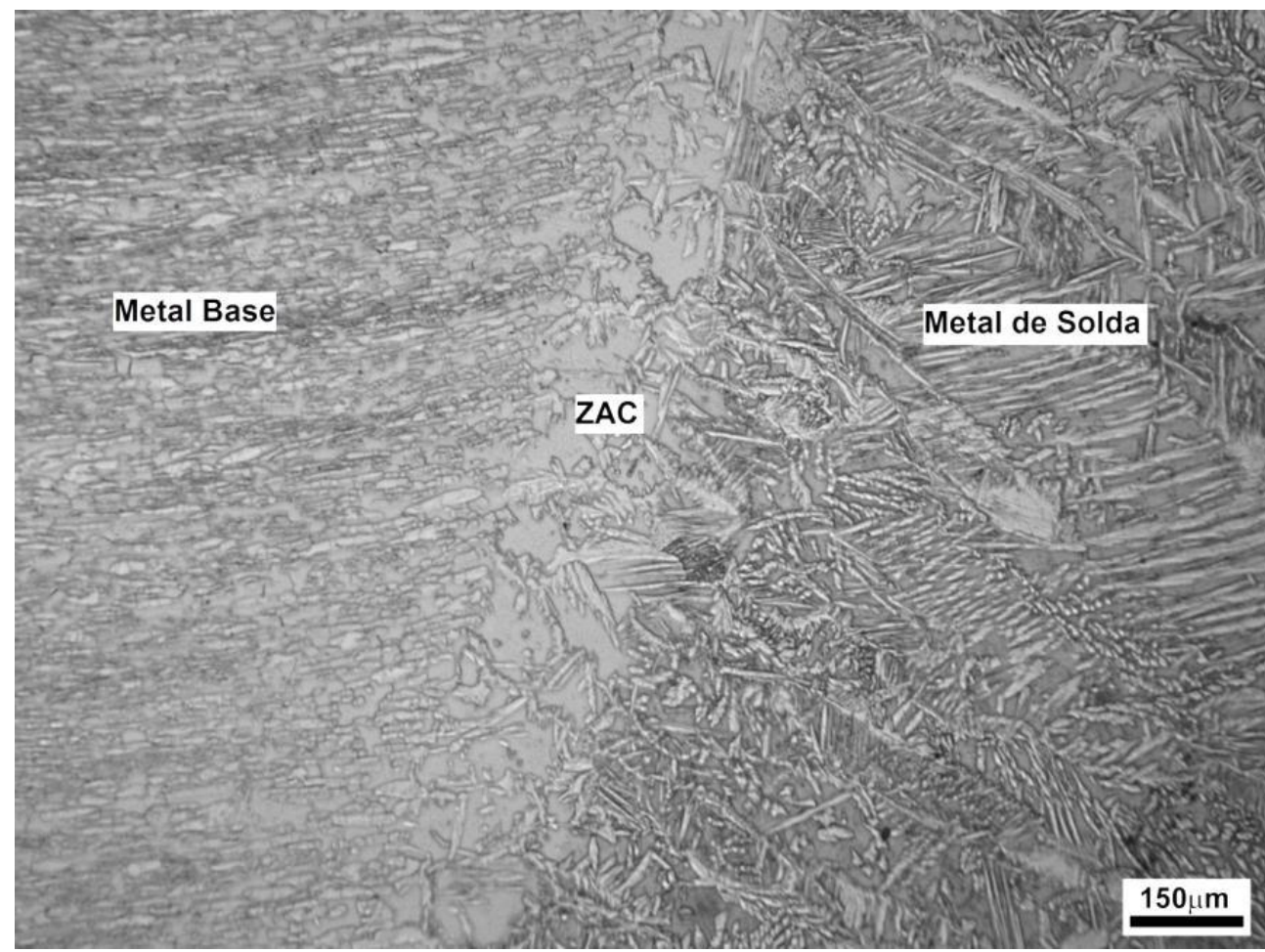

Figura 5.10: Vista frontal com ampliação de 100X do CP1 $(A+A+C A)$ com ataque oxálico.

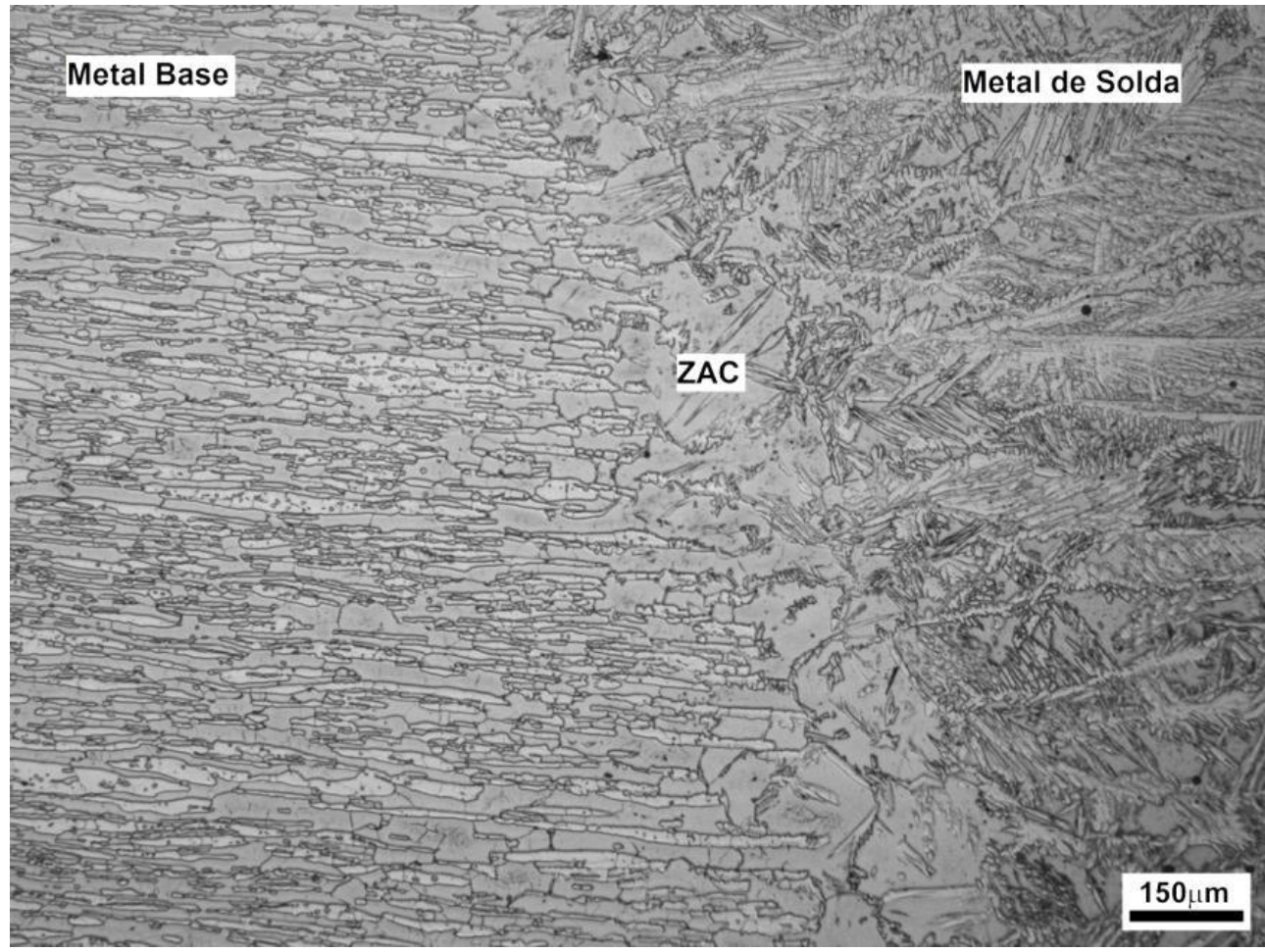

Figura 5.11: Vista frontal com ampliação de 100X do CP2 (B+B+CB) com ataque oxálico. 


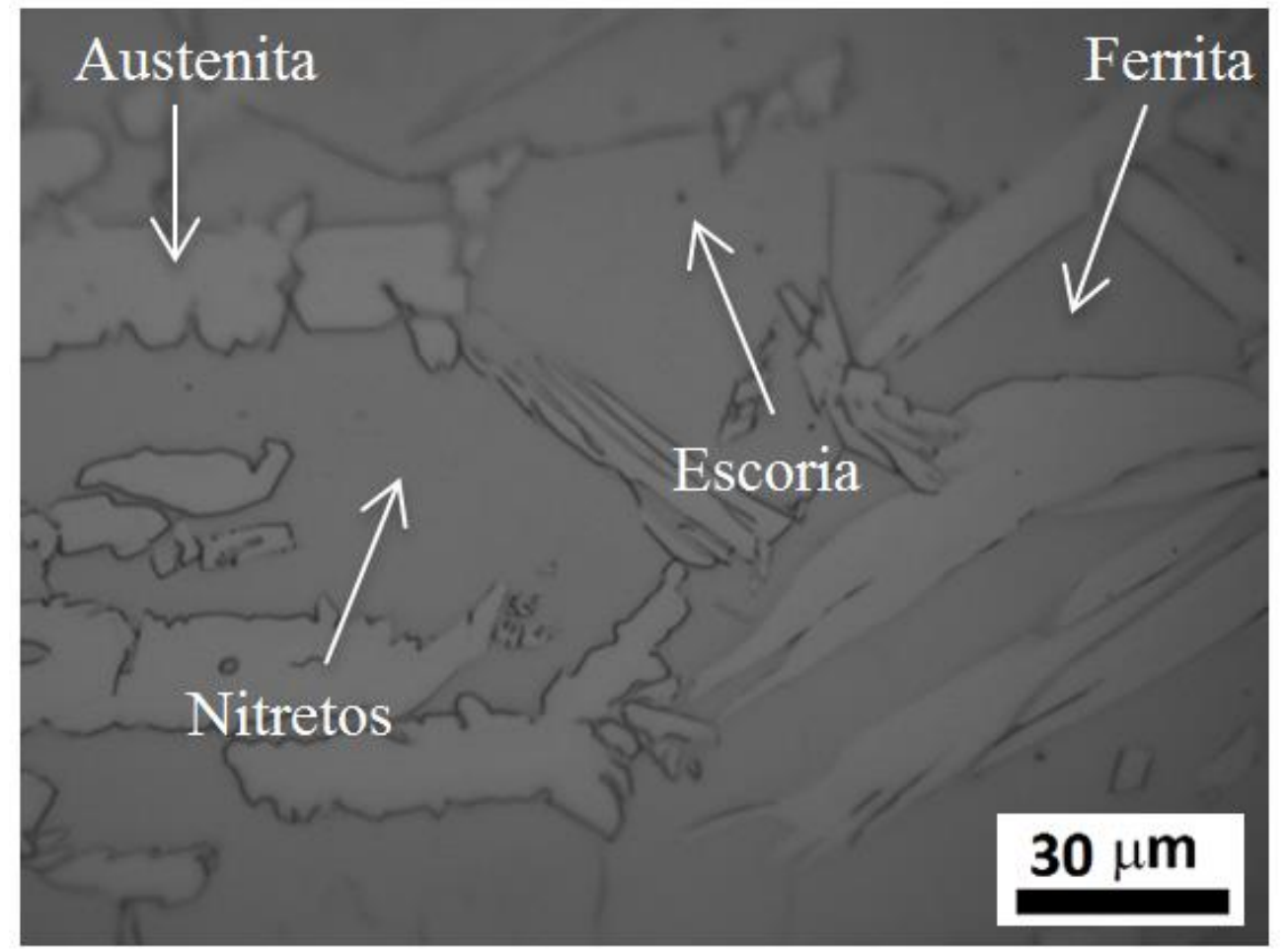

Figura 5.12: Microestrutura, vista superior com aumento de 1.000X, do metal de solda do CP5 $(A+B+C A)$.

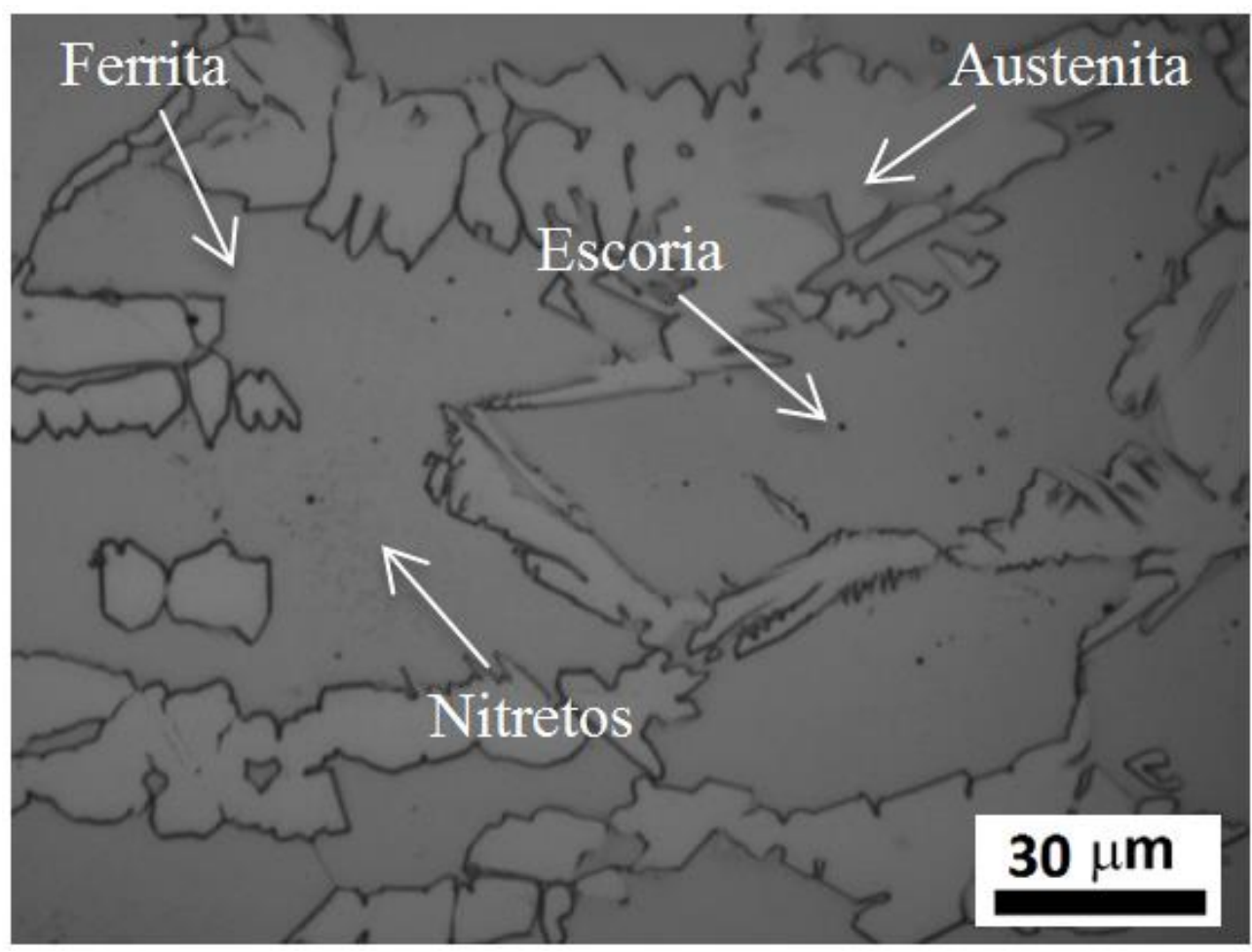

Figura 5.13: Microestrutura, vista superior com aumento de 1.000X, do metal de solda do CP6 $(\mathrm{A}+\mathrm{B}+\mathrm{CB})$. 


\subsubsection{FRAÇÃO VOLUMÉTRICA DA FERRITA}

Foram analisadas as regiões do metal de solda e da zona afetada pelo calor (ZAC) das amostras de todos os corpos de prova, previamente atacados quimicamente, ataque Behara II, figuras 5.14, 5.15 e 5.16, e realizada a contagem da fração volumétrica da ferrita constatou-se que os valores encontrados estão dentro do intervalo normativo de 30 a 70\%, conforme item 4.3.6 da Norsok Standard M-601 ed. 2008, e por este critério todos os corpos de prova foram considerados aprovados e os resultados estão apresentados na tabela 5.6.

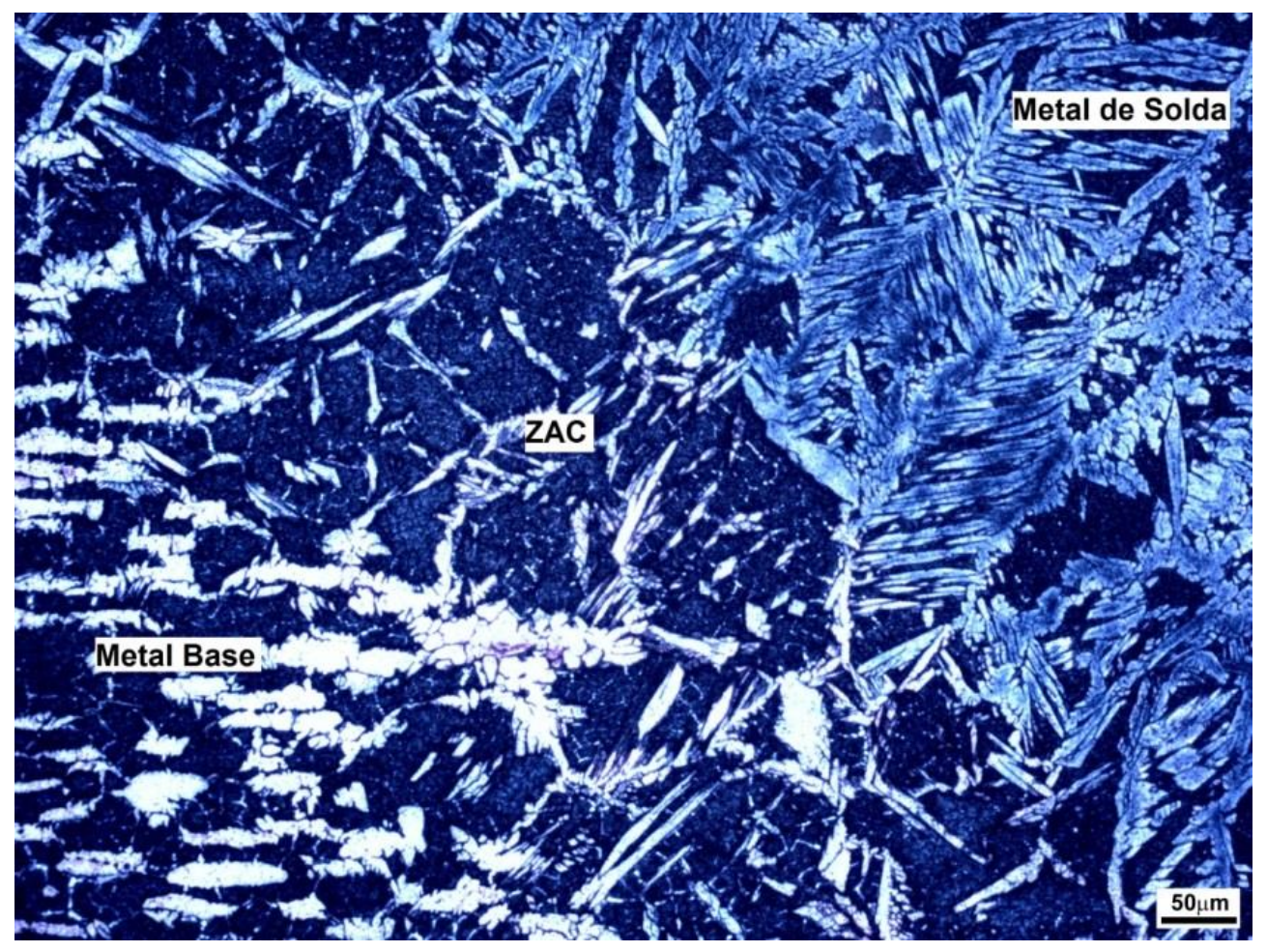

Figura 5.14: Vista frontal com ampliação de 200X do CP1 $(A+A+C A)$ com ataque Behara II. 


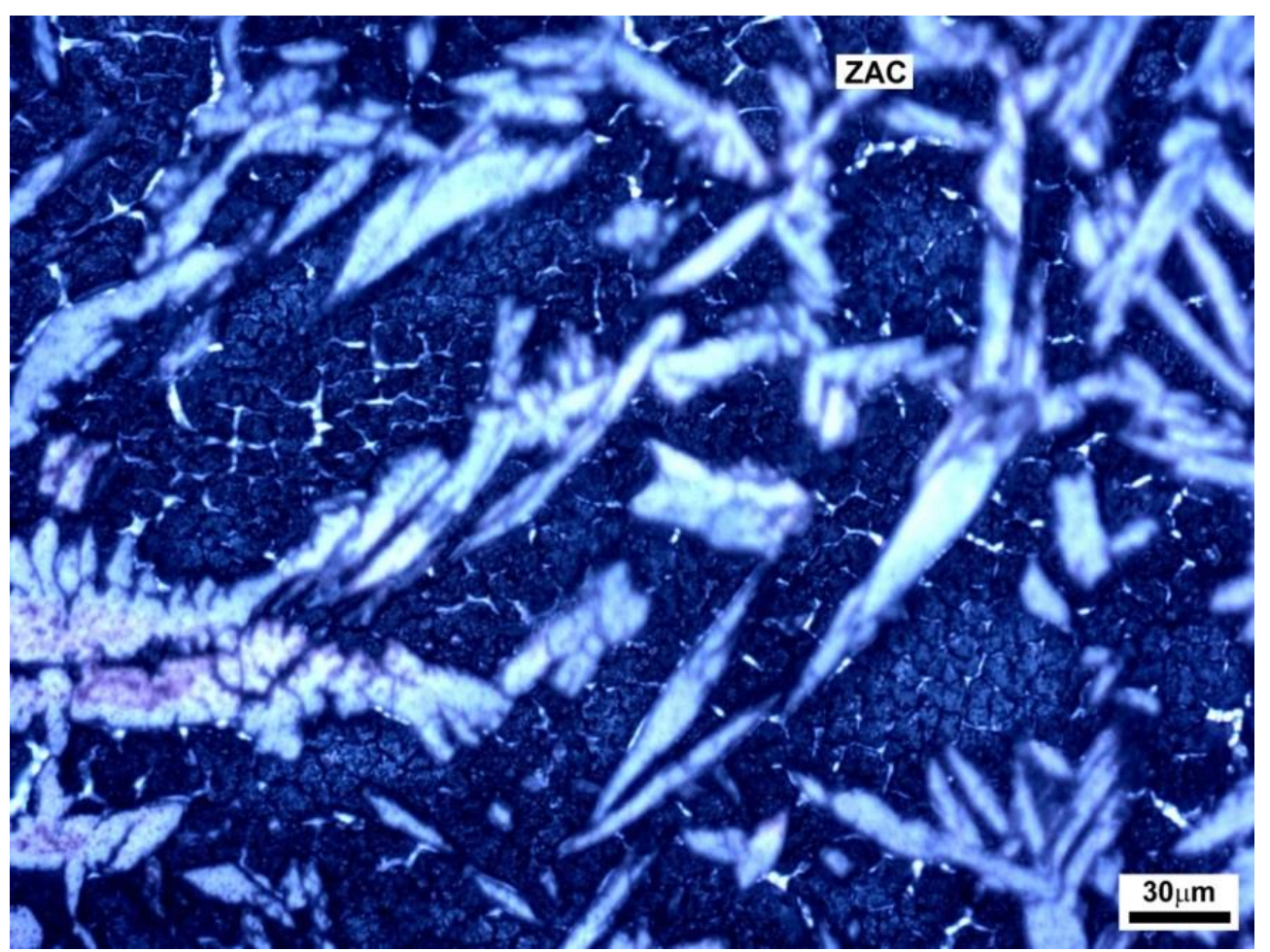

Figura 5.15: Vista frontal com ampliação de 200X da ZAC do CP1 $(A+A+C A)$ com ataque Behara II.

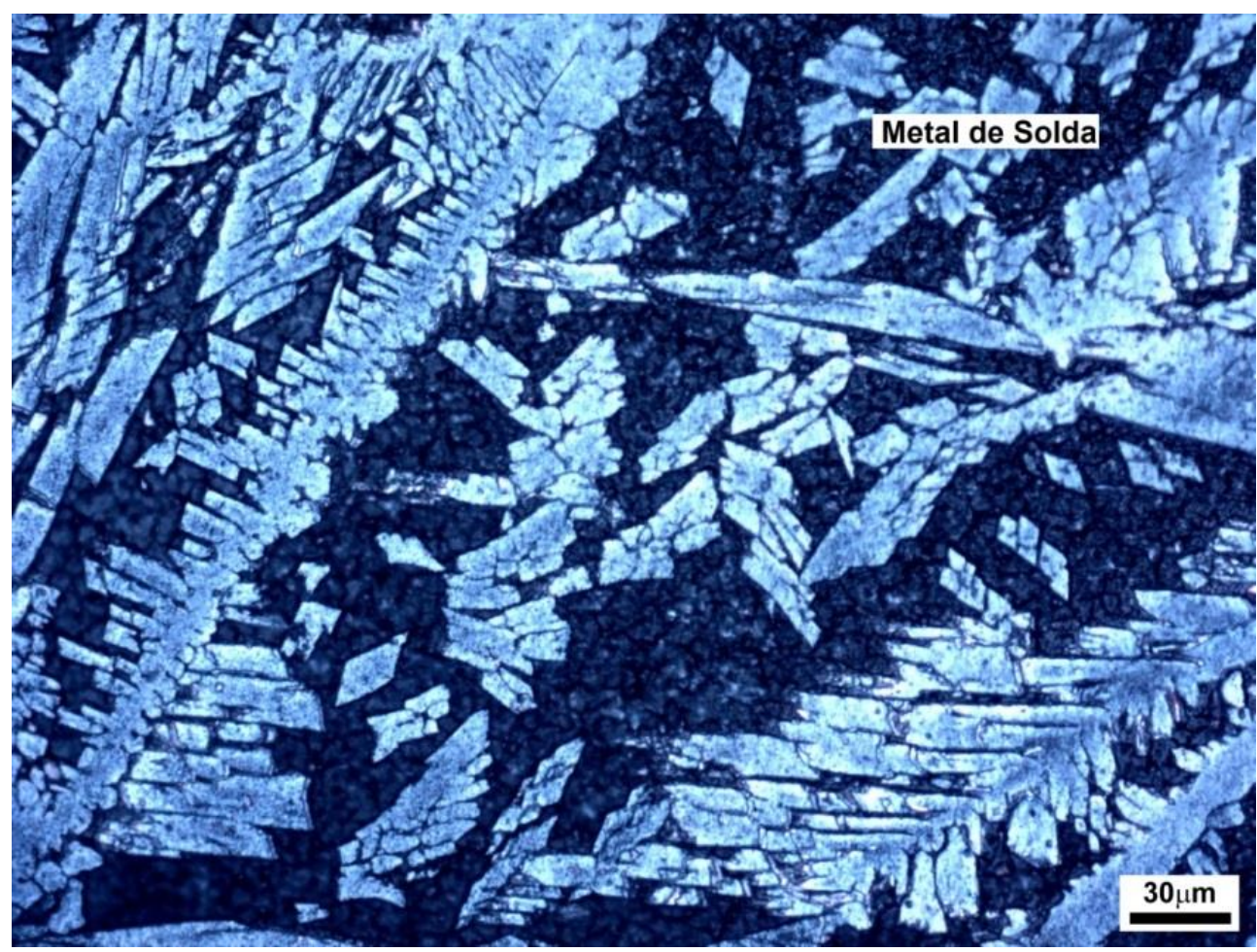

Figura 5.16: Vista frontal com ampliação de 200X da ZAC do CP1 $(A+A+C A)$ com ataque Behara II. 
Tabela 5.6: Quantitativo das frações volumétrica da ferrita no metal de solda e na ZAC.

\begin{tabular}{|c|c|c|c|c|c|}
\hline Material & Referência & Local & Média (\%) & Local & Média (\%) \\
\hline CP1 & A+A+CA & ZAC & $62,6 \pm 1,2$ & Metal de Solda & $37,5 \pm 1,4$ \\
\hline CP2 & B+B+CB & ZAC & $68,8 \pm 1,1$ & Metal de Solda & $41,1 \pm 1,2$ \\
\hline CP3 & A+B+CA & ZAC & $67,5 \pm 1,1$ & Metal de Solda & $61,9 \pm 1,1$ \\
\hline CP4 & A+B+CB & ZAC & $66,4 \pm 1,6$ & Metal de Solda & $49,9 \pm 1,7$ \\
\hline CP5 & A+B+CA & ZAC & $58,4 \pm 1,1$ & Metal de Solda & $39,0 \pm 1,2$ \\
\hline CP6 & A+B+CB & ZAC & $64,5 \pm 1,6$ & Metal de Solda & $39,1 \pm 1,4$ \\
\hline CP7 & A+B+CA & ZAC & $66,7 \pm 1,4$ & Metal de Solda & $40,8 \pm 1,1$ \\
\hline CP8 & A+B+CB & ZAC & $58,6 \pm 1,1$ & Metal de Solda & $43,6 \pm 1,6$ \\
\hline
\end{tabular}

\subsubsection{MICROSCOPIA ELETRÔNICA DE VARREDURA}

Foram analisadas amostras dos corpos de prova, com mesmo ataque utilizado para a microscopia ótica, no microscópio eletrônico de varredura utilizando-se elétrons retroespalhados o que permitiu a presença de carbetos no interior da ferrita bem como uma grande quantidade de micro inclusões de escória, comum para o processo de soldagem utilizado neste trabalho, não foi possível observar a presença de nitretos. Foi feita varredura nas interfaces austenita/ferrita a procura de formas que pudessem apresentar um aspecto mais brilhante, comum às fases deletérias devido a presença de elementos de liga de maior peso atômico, com o intuito de identificar a fase sigma e outras, porém apenas com esta técnica não houve sucesso.
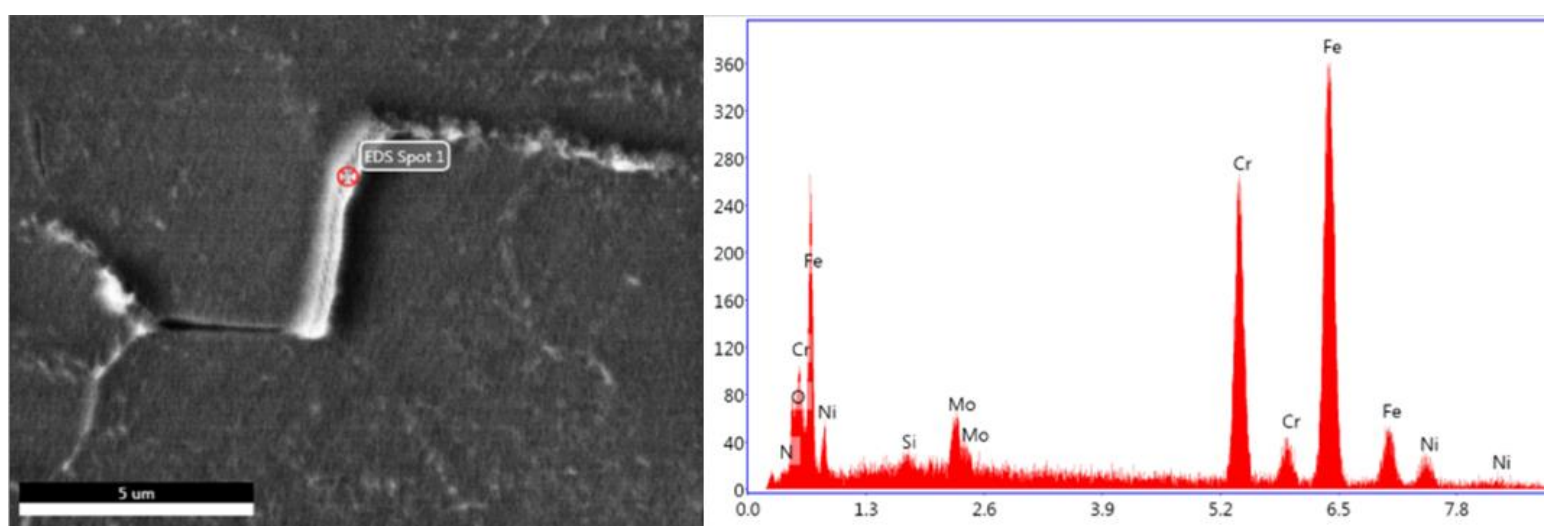

Figura 5.17: Micro inclusão de escória no $C P 5(A+B+C A)$ e composição química por EDS. 

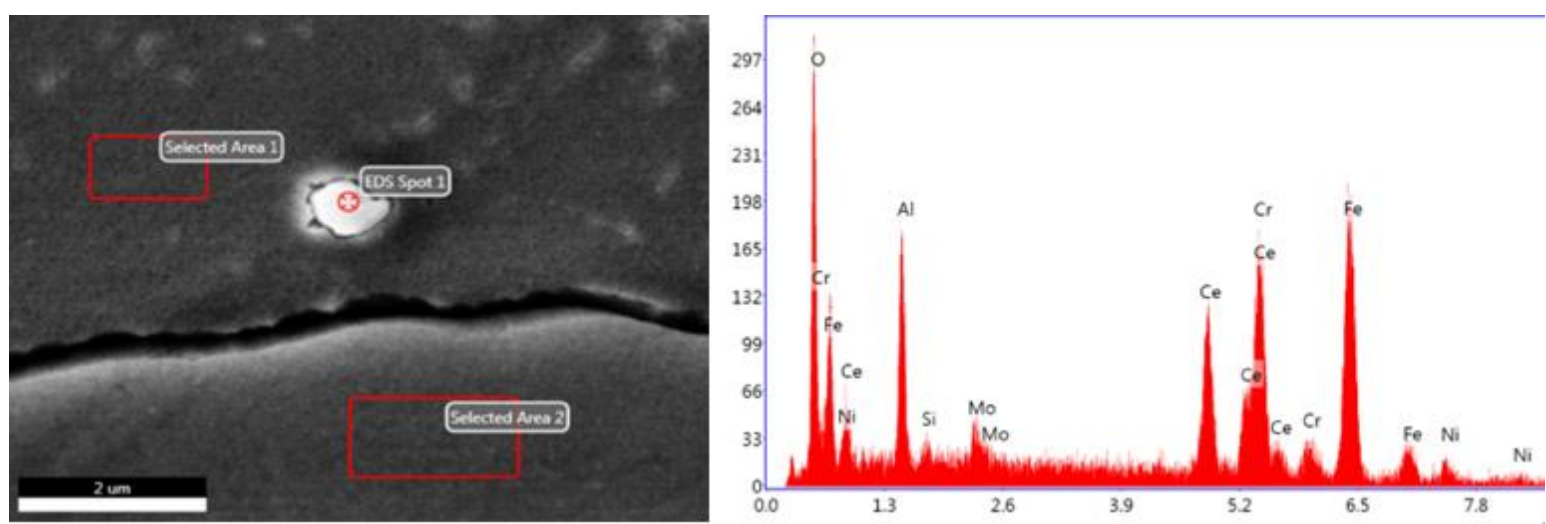

Figura 5.18: Micro inclusão de escória no $C P 1(A+A+C A)$ e composição química por EDS.
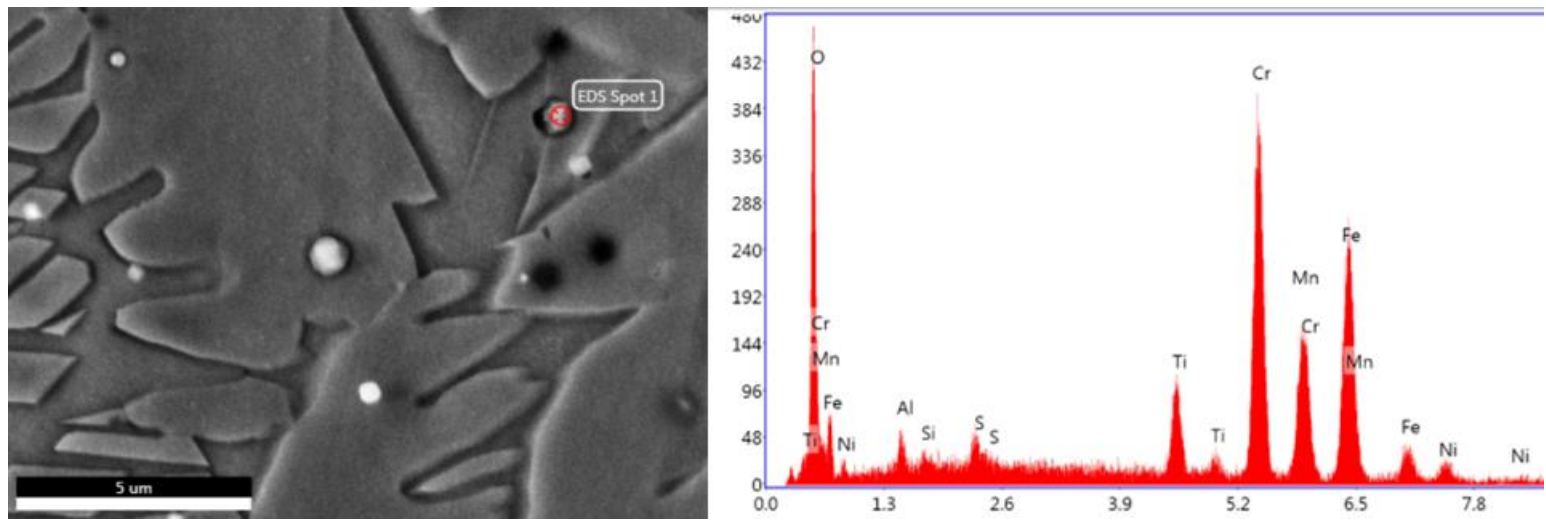

Figura 5.19: Micro inclusão de escória no $C P 6(A+B+C B)$ e composição química por EDS.
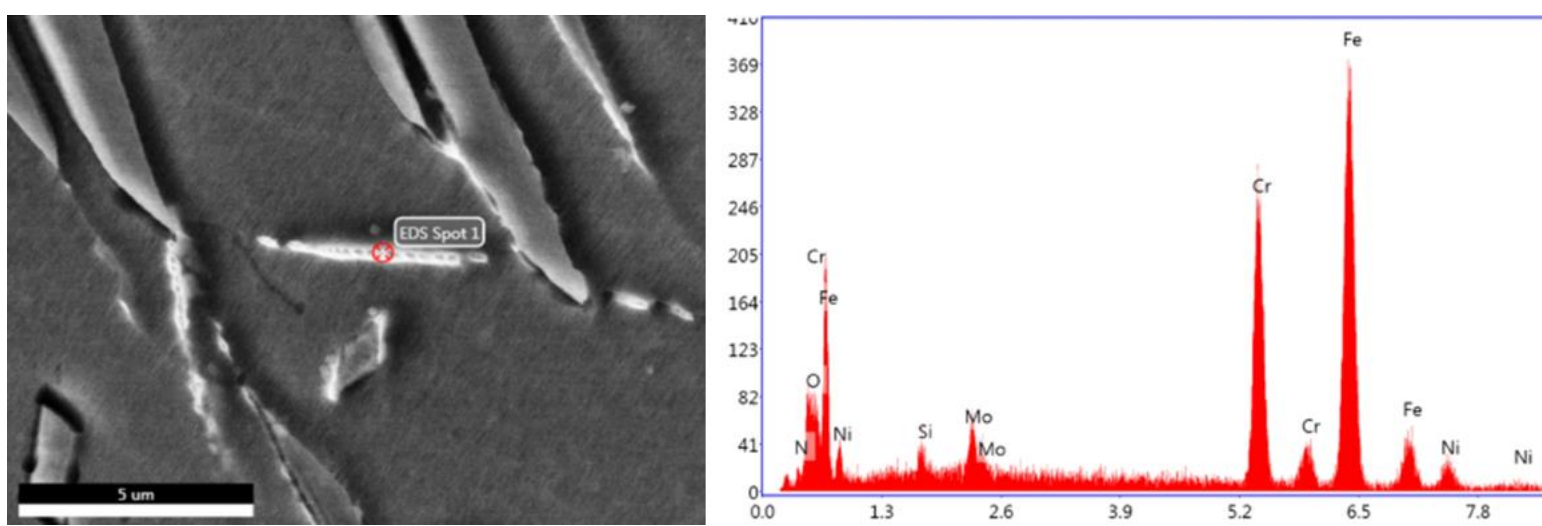

Figura 5.20: Micro inclusão de escória no CP6 $(A+B+C B)$ e composição química por EDS. 


\subsection{ENSAIOS NÃO DESTRUTIVOS}

\subsubsection{EXAME VISUAL DA SOLDA}

O exame visual das amostras foi realizado para verificar penetração total da solda e fusão completa do metal de solda com o metal base e após esta verificação não foram encontrados poros ou trincas visíveis, todas as juntas soldadas apresentaram boa penetração e também não ocorreram mordeduras laterais, que são causadas por correntes muito elevadas, e desta forma pode-se afirmar que a soldagem dos 8 corpos de prova foi satisfatória.

\subsubsection{ENSAIO COM LÍQUIDO PENETRANTE}

Após a completa inspeção de todos os corpos de prova submetidos ao ensaio de Líquido Penetrante não foram observadas descontinuidades superficiais tais como poros ou trincas nas juntas soldadas e desta forma pode-se afirmar que a soldagem dos 8 corpos de prova foi satisfatória e os corpos de prova foram considerados aprovados conforme os critérios da norma na qual este ensaio foi baseado, ASME IX QW-195.2.2 ed. 2013.

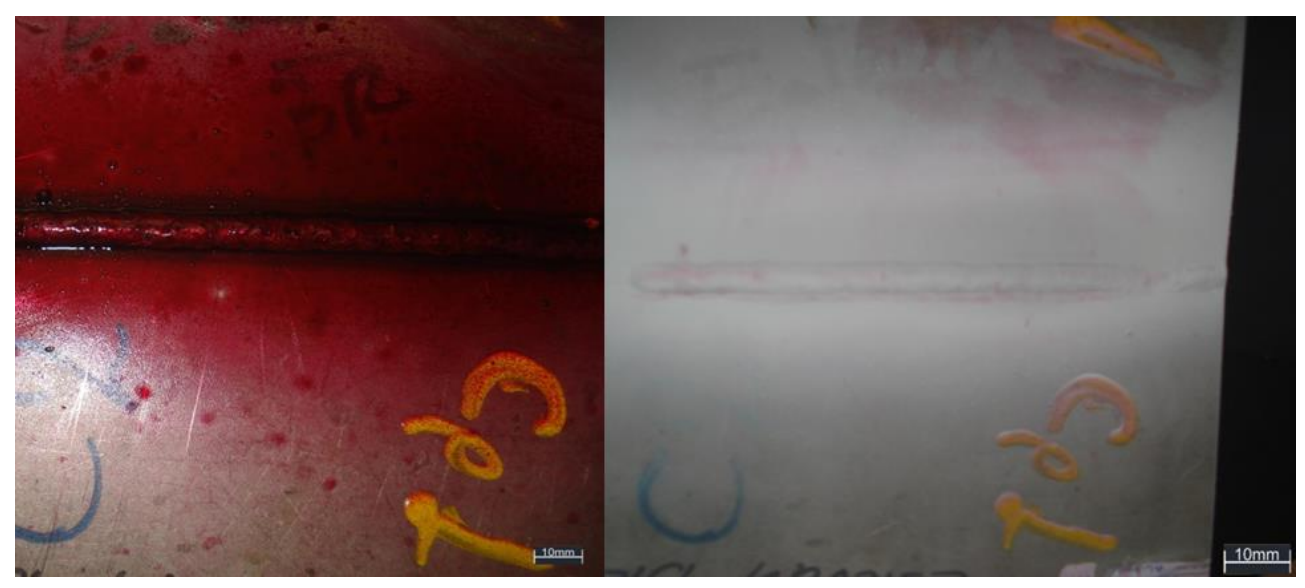

(a)

(b)

Figura 5.21: Corpo de prova CP1 $(A+A+C A)$ após limpeza e aplicação do líquido penetrante (a), corpo de prova após limpeza e aplicação do revelador (b). 


\subsection{ENSAIOS DESTRUTIVOS}

\subsubsection{ENSAIO DE IMPACTO (CHARPY “V”)}

Todos os corpos de prova submetidos ao ensaio de impacto, Charpy "V" a $-46{ }^{\circ} \mathrm{C}$ obtiveram valores de absorção de energia superiores a $27 \mathrm{~J}$, e segundo os critérios de aceitação da norma na qual este trabalho está baseado, todas as amostras testadas foram consideradas aprovadas segundo o item 4.3.2 da Norsok Standard M-601ed. 2008, que estabelece energia mínima de absorção de impacto de 27J. Os valores das energias absorvidas nos ensaios estão apresentados na tabela 5.7 e representados em um gráfico de barras na figura 5.22.

Tabela 5.7: Energias absorvidas pelos metais de solda (MS) e pelas zonas afetadas pelo calor (ZAC) no teste de impacto Charpy-V a $-46{ }^{\circ} \mathrm{C}$

\begin{tabular}{|c|c|c|c|c|}
\hline Amostra & Referência & MS (J) & ZAC (J) & Referência (J)* \\
\hline $\mathrm{CP} 1$ & $A+A+C A$ & $45,3 \pm 4,6$ & $73,3 \pm 4,6$ & 27 \\
\hline $\mathrm{CP} 2$ & $\mathrm{~B}+\mathrm{B}+\mathrm{CB}$ & $38,0 \pm 2,1$ & $66,0 \pm 13,1$ & 27 \\
\hline CP3 & $A+B+C A$ & $45,3 \pm 2,3$ & $50,7 \pm 4,6$ & 27 \\
\hline CP4 & $A+B+C B$ & $47,0 \pm 1,7$ & $69,0 \pm 15,9$ & 27 \\
\hline CP5 & $A+B+C A$ & $35,0 \pm 4,6$ & $45,3 \pm 15,5$ & 27 \\
\hline $\mathrm{CP} 6$ & $A+B+C B$ & $38,0 \pm 1,7$ & $59,0 \pm 13,5$ & 27 \\
\hline CP7 & $A+B+C A$ & $42,7 \pm 2,3$ & $54,7 \pm 12,2$ & 27 \\
\hline CP8 & $A+B+C B$ & $44,0 \pm 3,5$ & $95,0 \pm 12,1$ & 27 \\
\hline
\end{tabular}

* Segundo o critério de aceitação do item 4.3.2 da norma Norsok M-601 ed. 2008. 


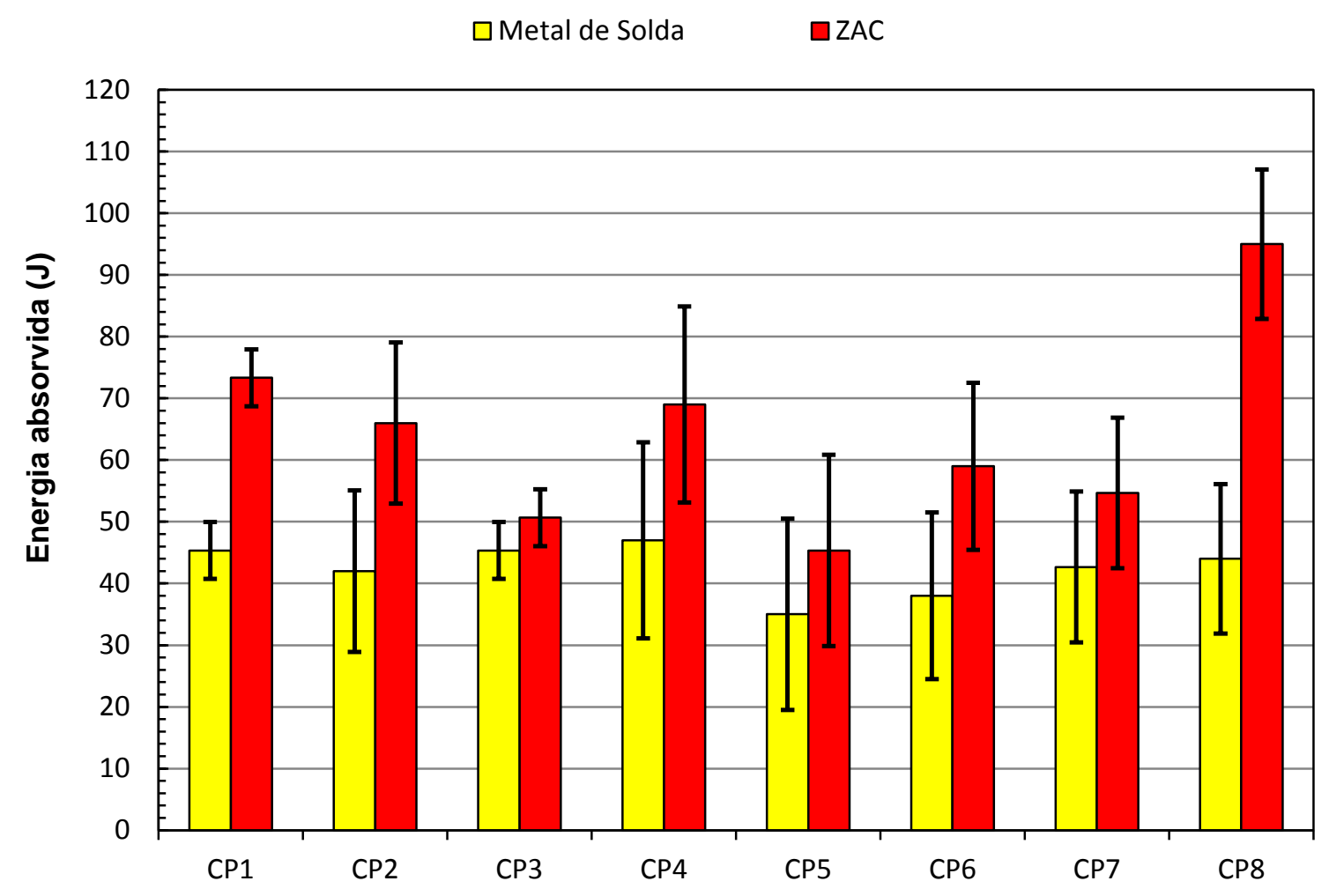

Figura 5.22: Energias absorvidas no teste de impacto Charpy- $\mathrm{V}$ a $-46^{\circ} \mathrm{C}$, a barra preta indica os valores de desvio.

\subsubsection{ENSAIO DE TRAÇÃO}

Todos os corpos de prova das soldagens dissimilares submetidos ao ensaio de tração romperam na região do metal de base e distante da região da ZAC, figuras 5.23 e 5.24, e segundo os critérios de aceitação da norma na qual este ensaio está baseado, as amostras testadas foram consideradas aprovadas segundo a norma ASME IX QW-153 ed. 2013, que estabelece que o limite de resistência do metal de solda deve ser igual ou superior ao do metal de base, região onde é esperada a ruptura. Contudo os corpos de prova das soldagens similares, $C P 1(A+A+C A)$ e CP2 $(B+B+C B)$, romperam na região da solda e os limites de resistência obtidos foram inferiores aos valores de seus respectivos metais de bases, $928 \mathrm{MPa}$ para o UNS S32750 e $874 \mathrm{MPa}$ para o UNS S32760, e ao analisar as fraturas nota-se uma grande quantidade de poros no interior das soldas, figuras 5.25, 5.26, 5.27 e 5.28, o que não foi detectado nos demais ensaios realizados até este momento, e segundo os critérios acima descritos os corpos de prova das soldagens similares, CP1 $(A+A+C A)$ e $C P 2(B+B+C B)$, foram reprovados. Os valores dos limites de resistência 
obtidos nos ensaios de tração, a identificação dos locais de ruptura e também os valores das temperaturas a que as regiões de ruptura foram expostas durante a soldagem estão apresentados na tabela 5.8 .

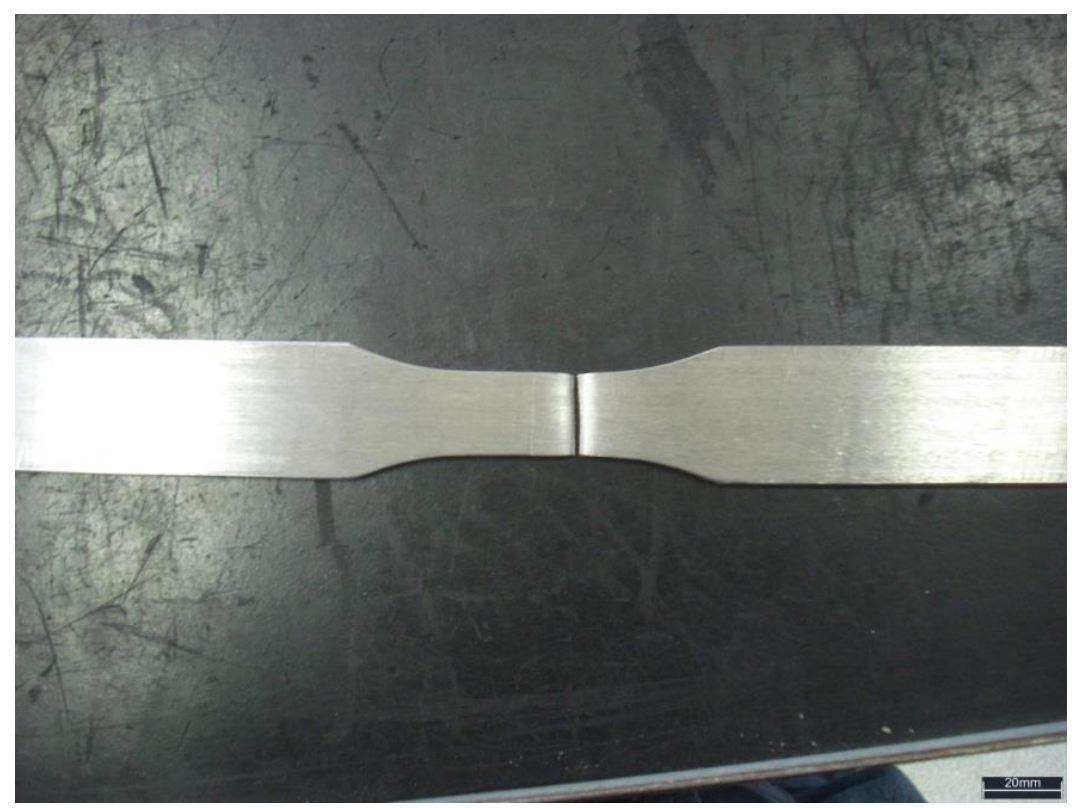

Figura 5.23: Corpo de prova $\mathrm{CP3}(\mathrm{A}+\mathrm{B}+\mathrm{CA})$ rompido no metal de base.

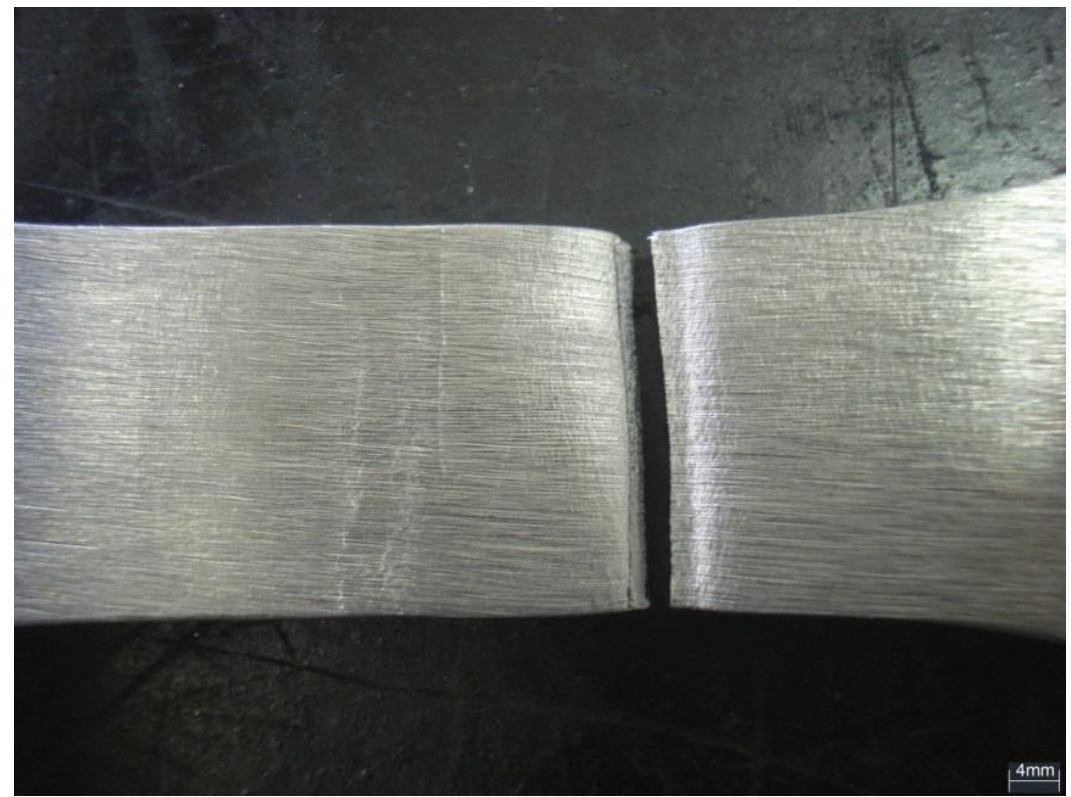

Figura 5.24: Detalhe da ruptura do $C P 3(A+B+C A)$ no metal de base, pode-se notar a região da solda ao lado esquerdo da ruptura. 


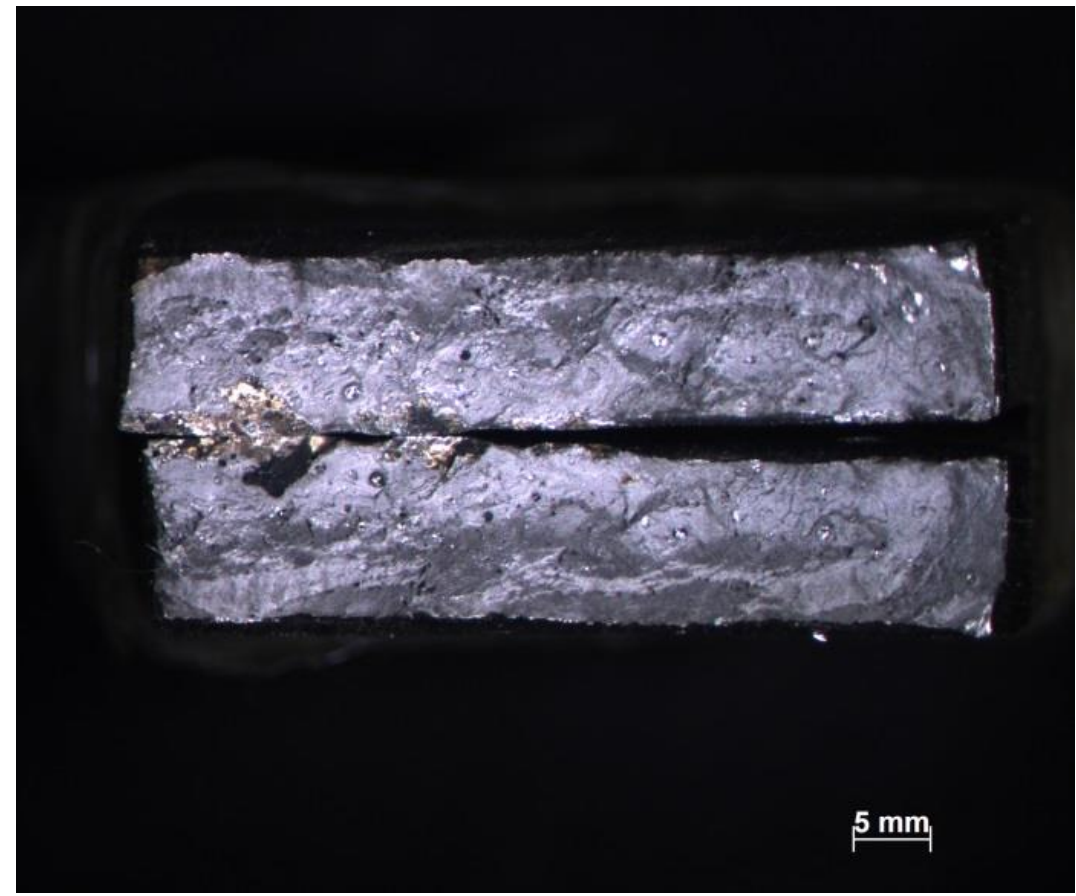

Figura 5.25: Fotos do $C P 1(A+A+C A)$ com aumento de $2 X$ nota-se uma grande quantidade de poros.

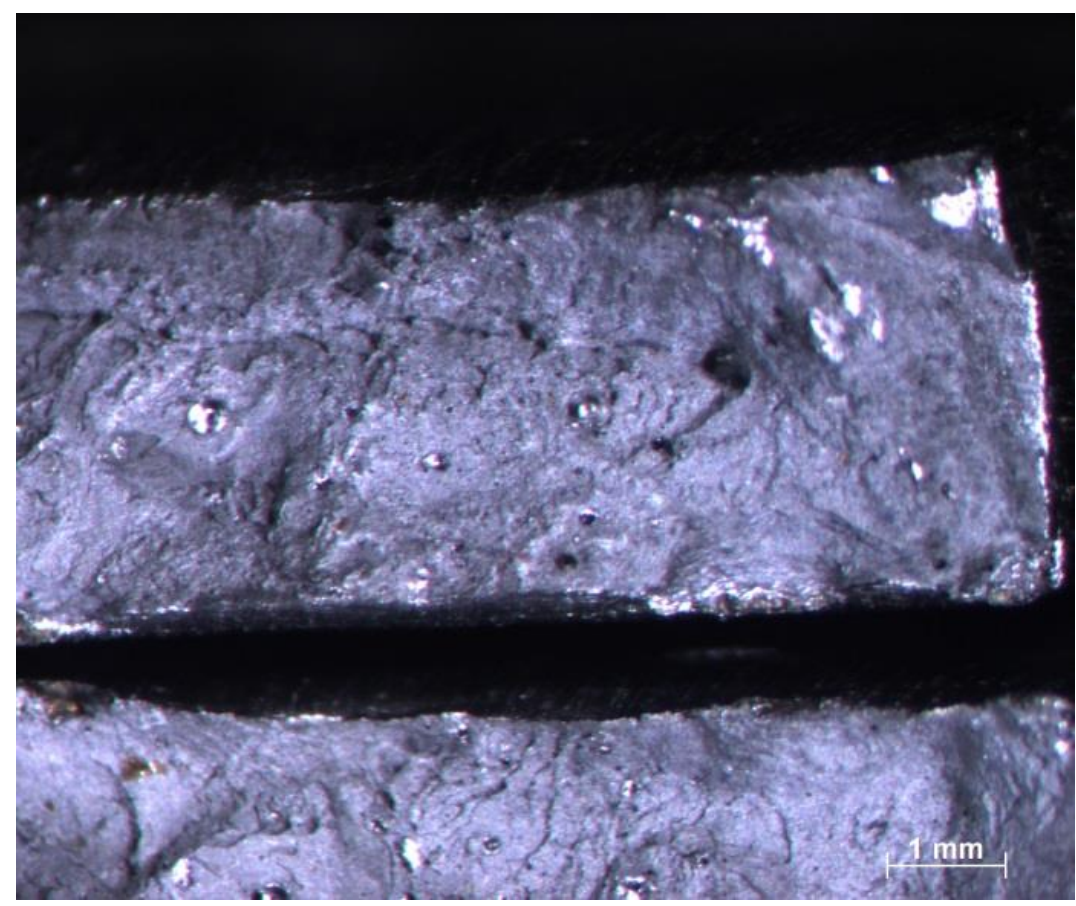

Figura 5.26: Fotos do $C P 1(A+A+C A)$ com aumento de $5 X$ nota-se uma grande quantidade de poros. 


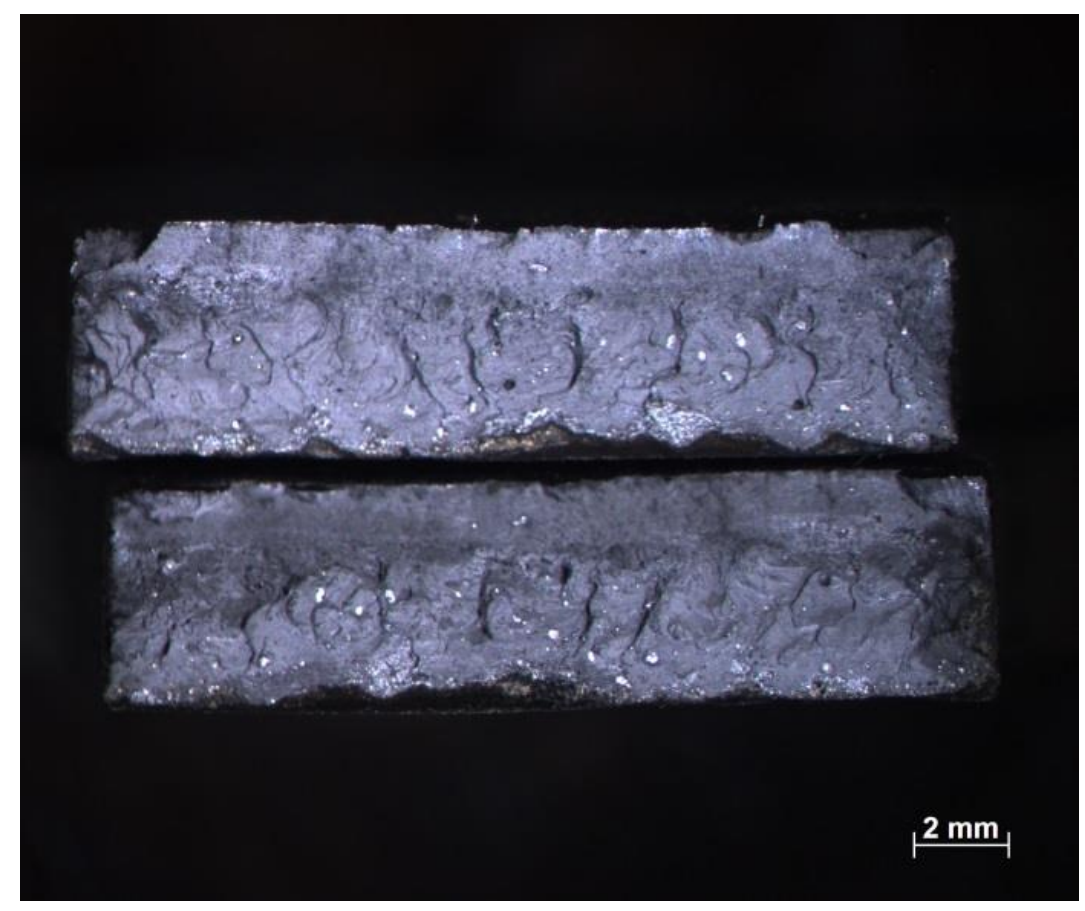

Figura 5.27: Fotos do $\mathrm{CP} 2(\mathrm{~B}+\mathrm{B}+\mathrm{CB}) \mathrm{com}$ aumento de $2 \mathrm{X}$ nota-se uma grande quantidade de poros.

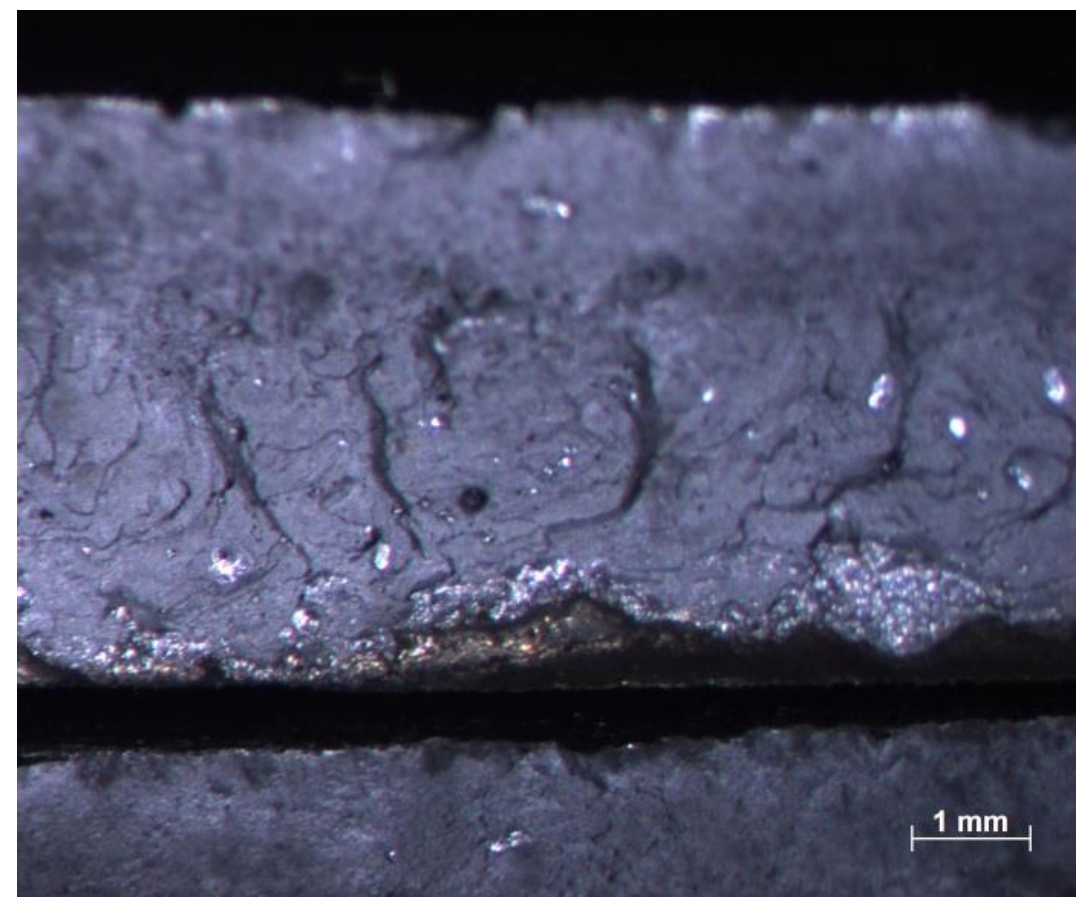

Figura 5.28: Fotos do $\mathrm{CP} 2(\mathrm{~B}+\mathrm{B}+\mathrm{CB})$ com aumento de $5 \mathrm{X}$ nota-se uma grande quantidade de poros. 
Tabela 5.8: Resultados do ensaio de tração

\begin{tabular}{|c|c|c|c|c|}
\hline Corpos & Referência & $\begin{array}{c}\text { Limite de resistência } \\
\text { (MPa) }\end{array}$ & $\begin{array}{c}\text { Temperatura } \\
(\mathbf{o})^{\star}\end{array}$ & Local da ruptura \\
\hline de fusão & Solda devido a poros internos \\
\hline CP2 & $\mathrm{A}+\mathrm{A}+\mathrm{CA}$ & 832 & de fusão & Solda devido a poros internos \\
\hline CP3 & $\mathrm{A}+\mathrm{B}+\mathrm{CB}+\mathrm{CA}$ & 848 & 350 & Metal base lado UNS S32760 \\
\hline CP4 & $\mathrm{A}+\mathrm{B}+\mathrm{CB}$ & 879 & 482 & Metal base lado UNS S32750 \\
\hline CP5 & $\mathrm{A}+\mathrm{B}+\mathrm{CA}$ & 881 & 520 & Metal base lado UNS S32750 \\
\hline CP6 & $\mathrm{A}+\mathrm{B}+\mathrm{CB}$ & 876 & 495 & Metal base lado UNS S32750 \\
\hline CP7 & $\mathrm{A}+\mathrm{B}+\mathrm{CA}$ & 886 & 480 & Metal base lado UNS S32760 \\
\hline CP8 & $\mathrm{A}+\mathrm{B}+\mathrm{CB}$ & 874 & 470 & Metal base lado UNS S32760 \\
\hline
\end{tabular}

* Temperatura alcançada na região de ruptura durante a soldagem.

\subsubsection{ENSAIO DE DOBRAMENTO}

Todos os corpos de prova foram submetidos ao ensaio de dobramento, figura 5.29, e em nenhuma das amostras testadas foram encontradas trincas e ou aberturas superiores a $1,5 \mathrm{~mm}$ e segundo os critérios de aceitação da norma na qual este ensaio está baseado todos os corpos de prova testados foram considerados aceitos conforme a norma ASME IX QW-163 ed. 2013, que admite aberturas de até 3,2 mm em qualquer direção, os valores das descontinuidades encontradas neste ensaio estão apresentados na tabela 5.9.

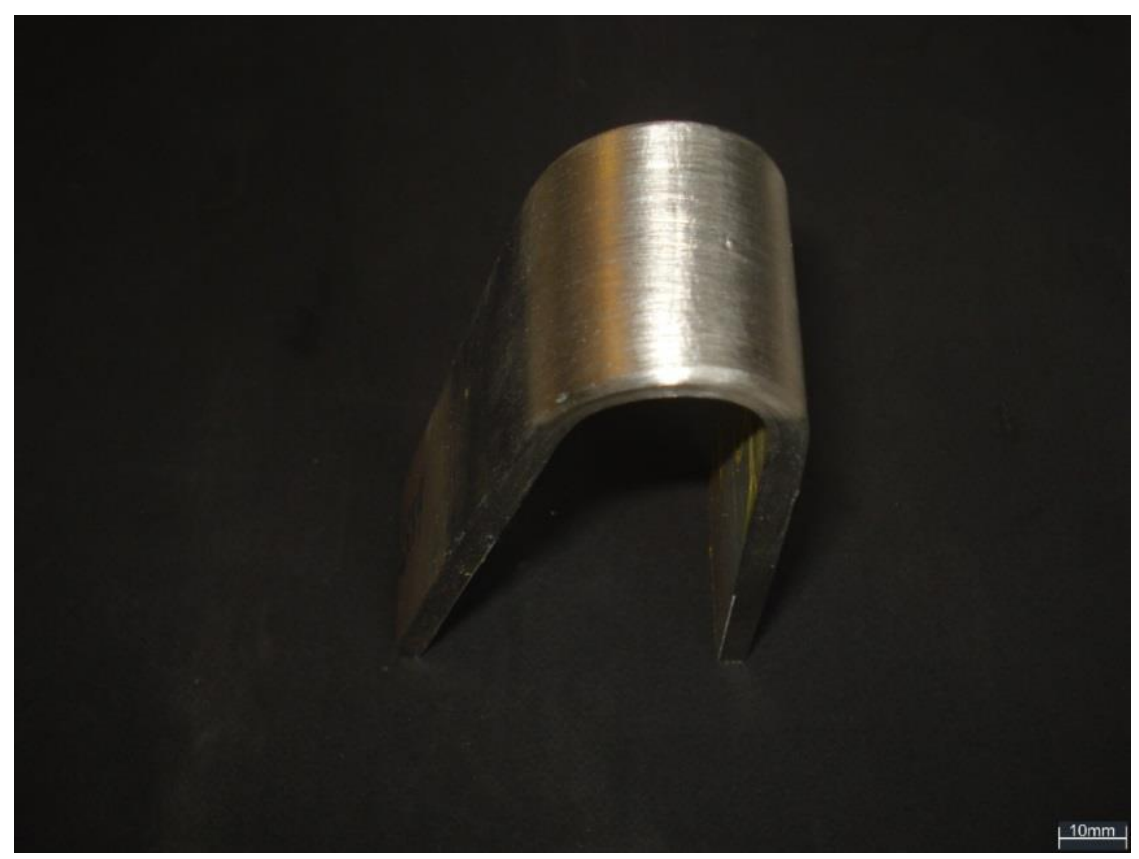

Figura 5.29: Detalhe da parte externa do $C P 4(A+B+C B)$ dobrada com a solda ao meio. 
Tabela 5.9: Resultados do ensaio de dobramento a $180^{\circ}$ e raio de $12,5 \mathrm{~mm}$

\begin{tabular}{|c|c|l|}
\hline Corpos & Referência & Descontinuidades \\
\hline CP1 & $A+A+C A$ & 2 aberturas de $0,7 \mathrm{~mm}$ e $0,8 \mathrm{~mm}$ na solda \\
\hline CP2 & $B+B+C B$ & Não apresentou descontinuidade \\
\hline CP3 & $A+B+C A$ & 1 abertura de $1,5 \mathrm{~mm}$ na solda \\
\hline CP4 & $A+B+C B$ & 4 aberturas de $1,5 \mathrm{~mm}, 0,9 \mathrm{~mm}, 0,7 \mathrm{~mm}$ e $0,4 \mathrm{~mm}$ na solda \\
\hline CP5 & $A+B+C A$ & 2 aberturas de $0,5 \mathrm{~mm}$ cada na solda \\
\hline CP6 & $A+B+C B$ & 1 abertura de $1,1 \mathrm{~mm}$ na solda \\
\hline CP7 & $A+B+C A$ & 1 abertura de $0,6 \mathrm{~mm}$ na solda \\
\hline CP8 & $A+B+C B$ & 2 aberturas de $1,0 \mathrm{~mm}$ e $0,5 \mathrm{~mm}$ na solda \\
\hline
\end{tabular}

\subsubsection{ENSAIOS DE CORROSÃO}

\subsubsection{ENSAIO DE CORROSÃO G-48}

As amostras foram submetidas ao ensaio de corrosão G-48, com temperatura um pouco superior a $40{ }^{\circ} \mathrm{C}$ e com exposição de 30 horas, imersas em solução de cloreto férrico hexa-hidratado $\left(\mathrm{FeCl}_{3} \cdot 6 \mathrm{H}_{2} \mathrm{O}\right)$ de $\mathrm{pH}=3$, abrangendo as regiões do metal base, das soldas e das zonas afetadas pelo calor (ZAC). Amostras utilizadas possuem área total de exposição de $20,8 \mathrm{~cm}^{2}$, todas as amostras obtiveram valores de taxa de corrosão inferiores a $0,0001 \mathrm{~g} / \mathrm{cm}^{2}$ e de com critérios do item 14, nota 21 da norma ASTM G-48 todas as amostras foram consideradas satisfatórias, a figura 5.30 mostra os $C P 1(A+A+C A)$ e $C P 4(A+B+C B)$ e os resultados estão apresentados na tabela 5.10 .

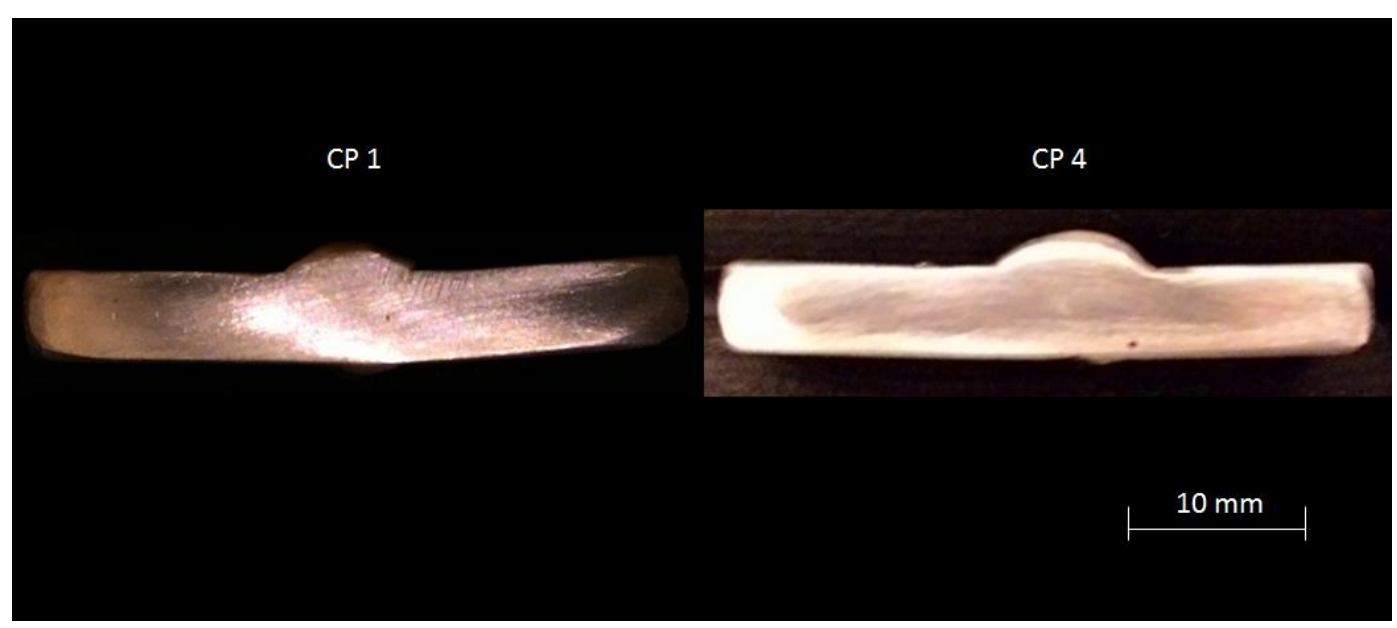

Figura 5.30: Fotos dos CP1 $(A+A+C A)$ e CP4 $(A+B+C B)$ após o ensaio G-48. 
Tabela 5.10: Resultados do ensaio de corrosão

\begin{tabular}{|c|c|c|c|c|}
\hline Corpos & Referência & Peso inicial $(\mathbf{g})$ & Peso final $\mathbf{( g )}$ & Taxa de corrosão (g/cm2) \\
\hline CP1 & A+A+CA & 41,1124 & 41,1119 & $2,40385 \mathrm{E}-05$ \\
\hline CP2 & B+B+CB & 40,5432 & 40,5428 & $1,92308 \mathrm{E}-05$ \\
\hline CP3 & A+B+CA & 41,4384 & 41,4379 & $2,40385 \mathrm{E}-05$ \\
\hline CP4 & A+B+CB & 42,1949 & 42,1945 & $1,92308 \mathrm{E}-05$ \\
\hline CP5 & A+B+CA & 42,8437 & 42,8432 & $2,40385 \mathrm{E}-05$ \\
\hline CP6 & A+B+CB & 41,5253 & 41,5247 & $2,88462 \mathrm{E}-05$ \\
\hline CP7 & A+B+CA & 39,6374 & 39,6371 & $1,44231 \mathrm{E}-05$ \\
\hline CP8 & A+B+CB & 42,7354 & 42,7352 & $9,61538 \mathrm{E}-06$ \\
\hline
\end{tabular}

\subsubsection{TÉCNICA LOCALIZADA DE SVET}

Os resultados apresentados indicam valores de densidade de corrente iônica em $\mathrm{mA} / \mathrm{cm}^{2}$, e os valores medidos são função da distribuição destas correntes características dos processos que ocorrem na superfície da amostra, associados à uma escala com graduação por cores. Geralmente as regiões Anódicas, onde efetivamente está ocorrendo a corrosão devido ao fluxo de íons, perda por corrosão, são representadas pela cor vermelha, e as regiões Catódicas, onde estão ocorrendo reações de redução são representadas pela cor azul, mas a efetiva indicação de corrosão está associada ao sinal da corrente positiva, visto que os elétrons seguem em sentido contrário. Apesar desta técnica não fazer parte do escopo deste trabalho, foi realizada apenas em caráter qualitativo, e é altamente ilustrativo poder ver representado de forma gráfica o processo de corrosão que ocorreu em algumas regiões das amostras, quando atacadas com $3,5 \% \mathrm{NaCl}$ em massa acidificada com $\mathrm{HCl}$ e com $\mathrm{pH}=2$. As figuras abaixo apresentam as imagens 2D e 3D dos corpos de prova $\mathrm{CP} 1(\mathrm{~A}+\mathrm{A}+\mathrm{CA}), \mathrm{CP} 2(\mathrm{~A}+\mathrm{B}+\mathrm{CB}), \mathrm{CP} 5(\mathrm{~A}+\mathrm{B}+\mathrm{CA})$ e CP6 $(\mathrm{A}+\mathrm{B}+\mathrm{CB})$ após 2, 6 e 20 horas de ensaio, ao lado de cada imagem 2D está apresentada a respectiva metalografia do corpo de prova para melhor identificação das regiões de cada amostra ensaiada. 

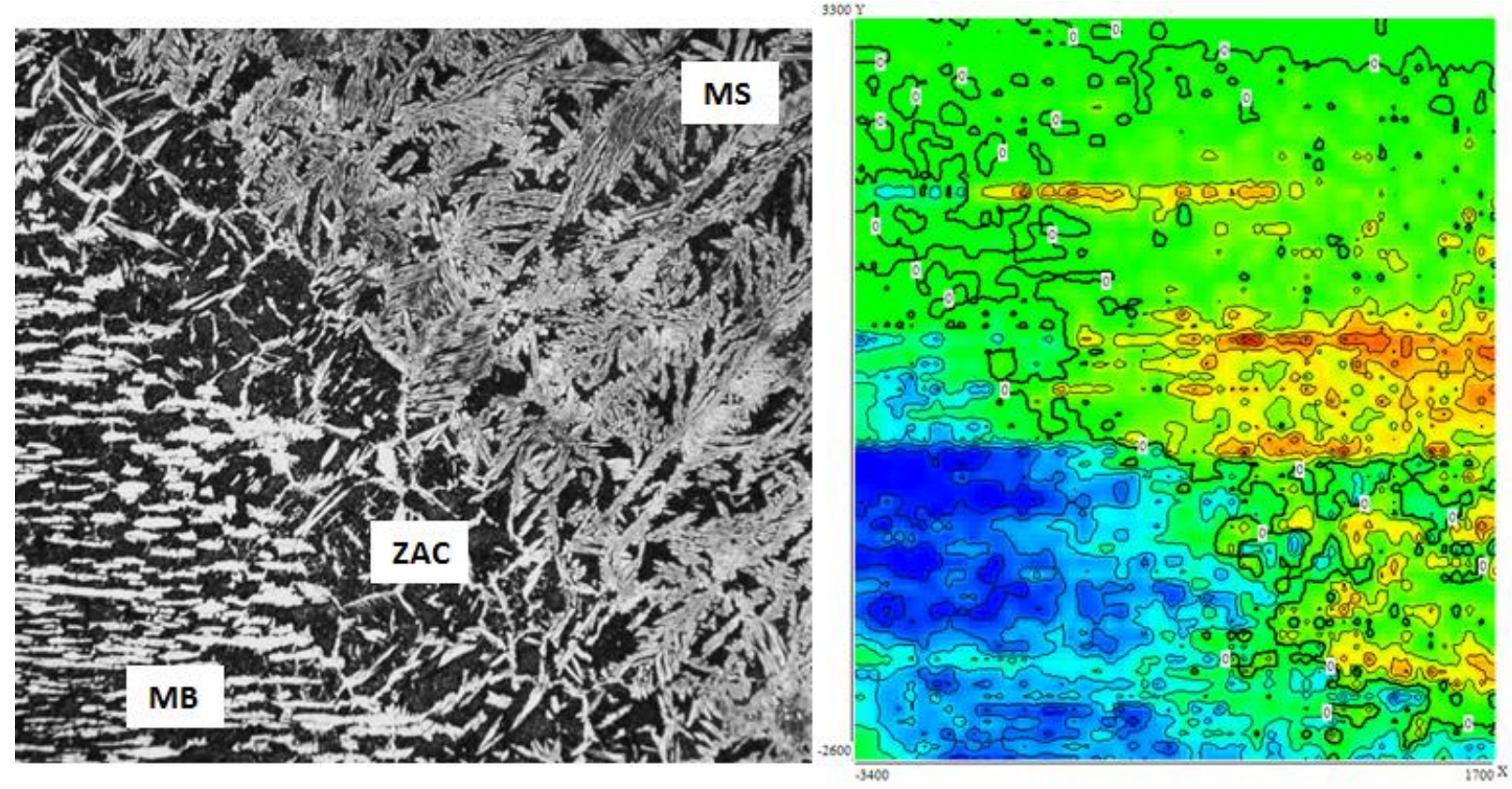

Figura 5.31: Imagem em 2D das densidades das correntes iônicas no CP1 $(A+A+C A)$ após 2h de ensaio.

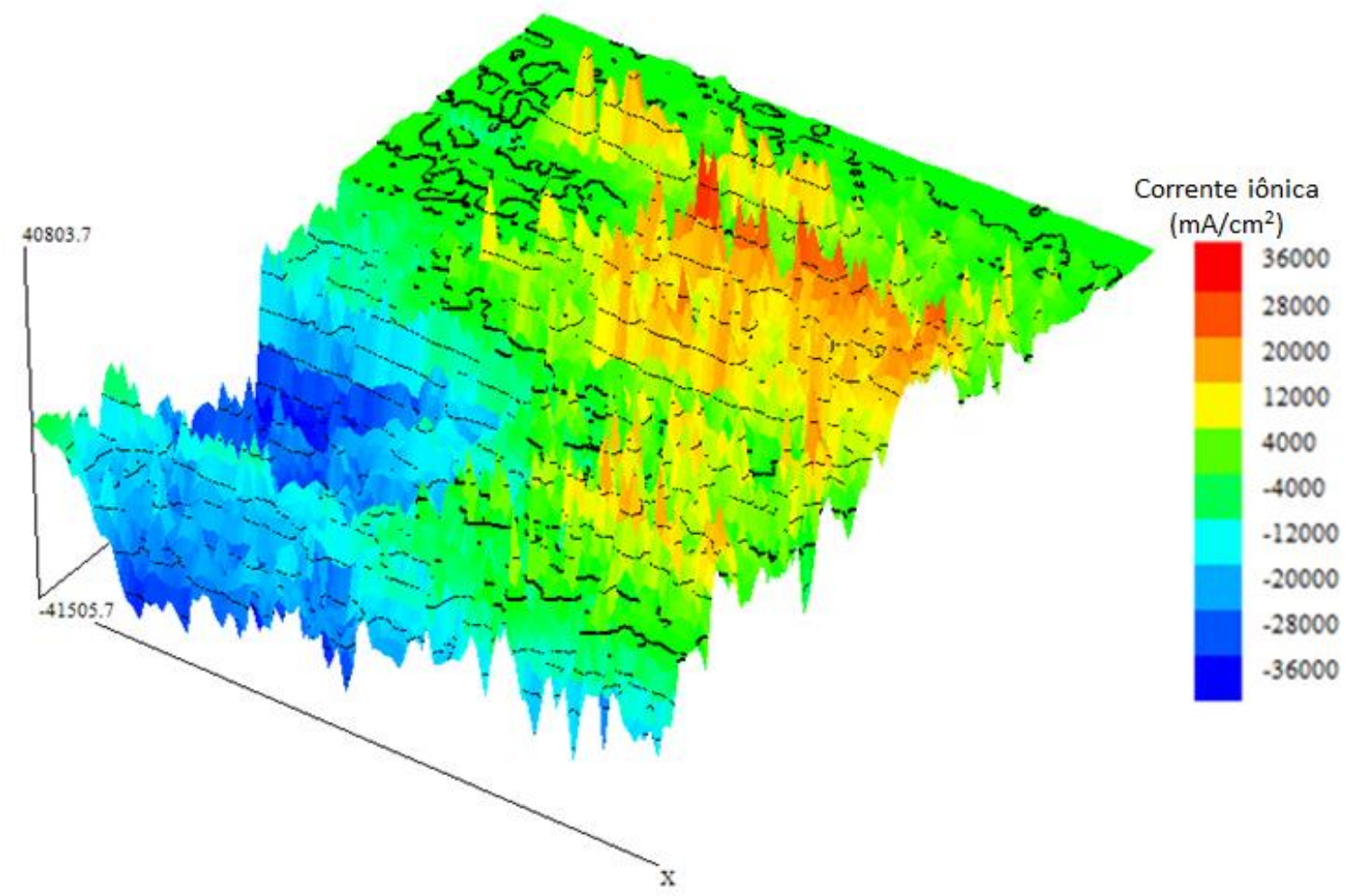

Figura 5.32: Imagem em 3D das densidades das correntes iônicas no CP1 $(A+A+C A)$ após $2 h$ de ensaio. 

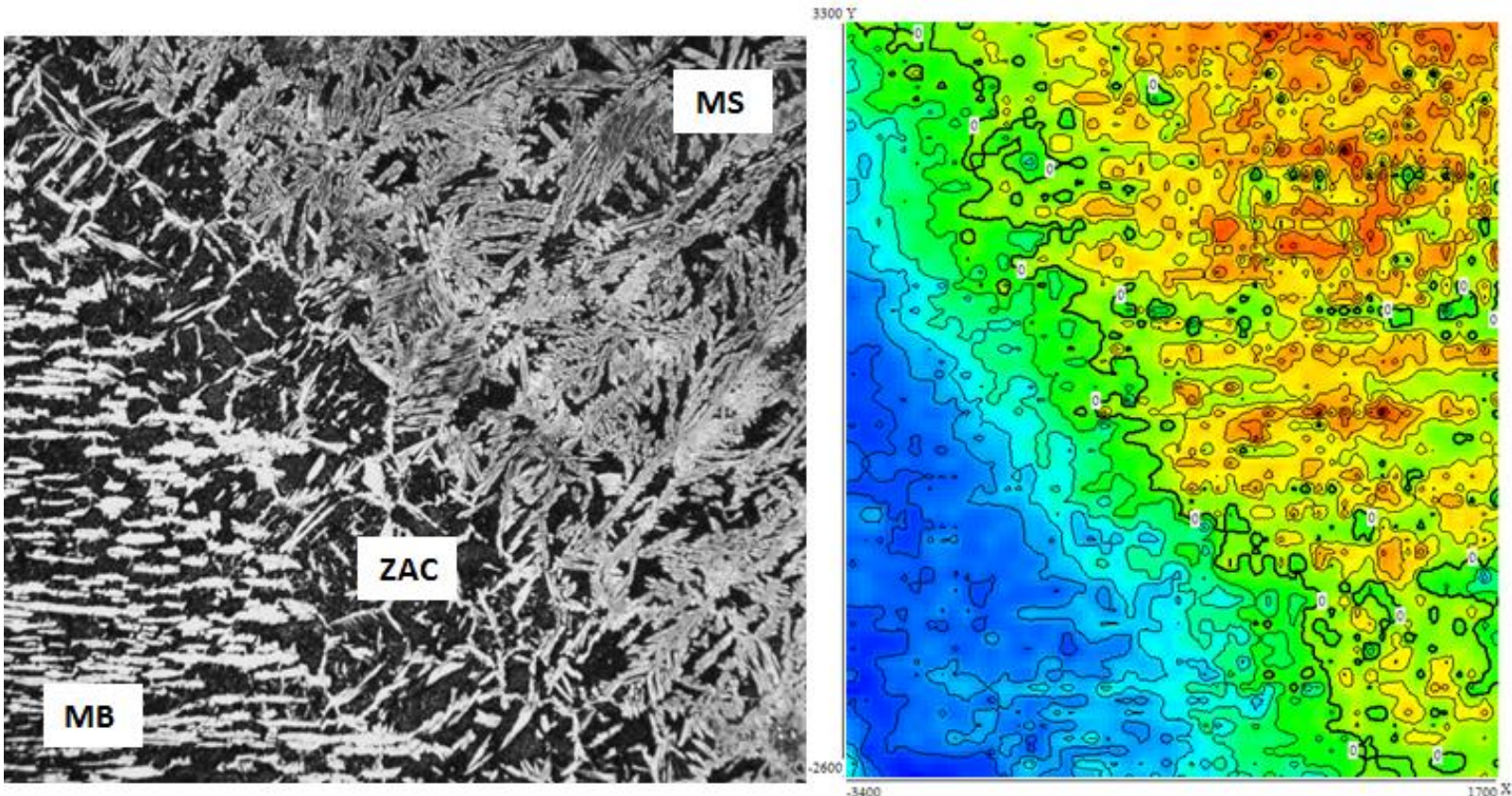

Figura 5.33: Imagem em 2D das densidades das correntes iônicas no $C P 1(A+A+C A)$ após 6 h de ensaio.

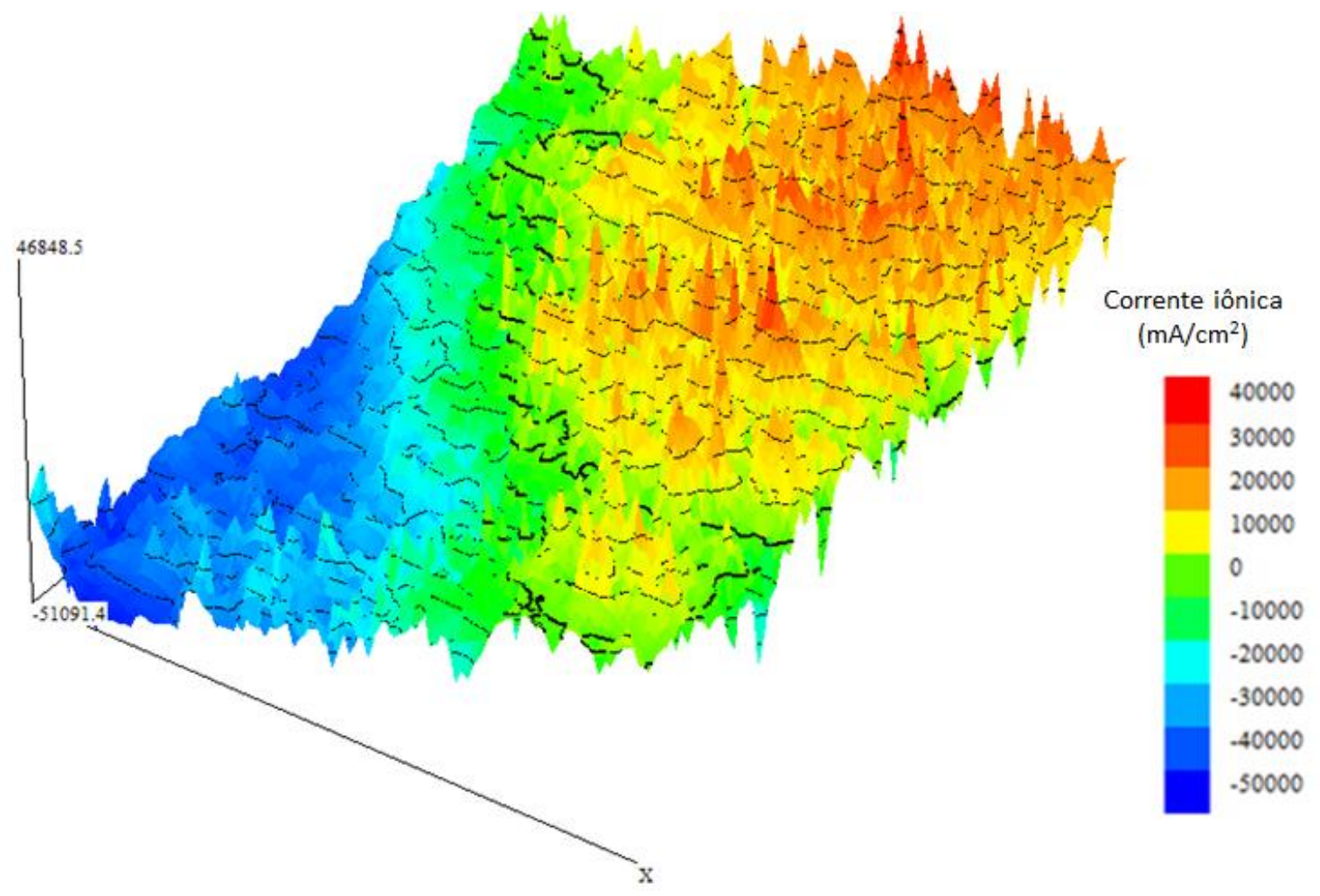

Figura 5.34: Imagem em 3D das densidades das correntes iônicas no CP1 $(A+A+C A)$ após 6 h de ensaio. 


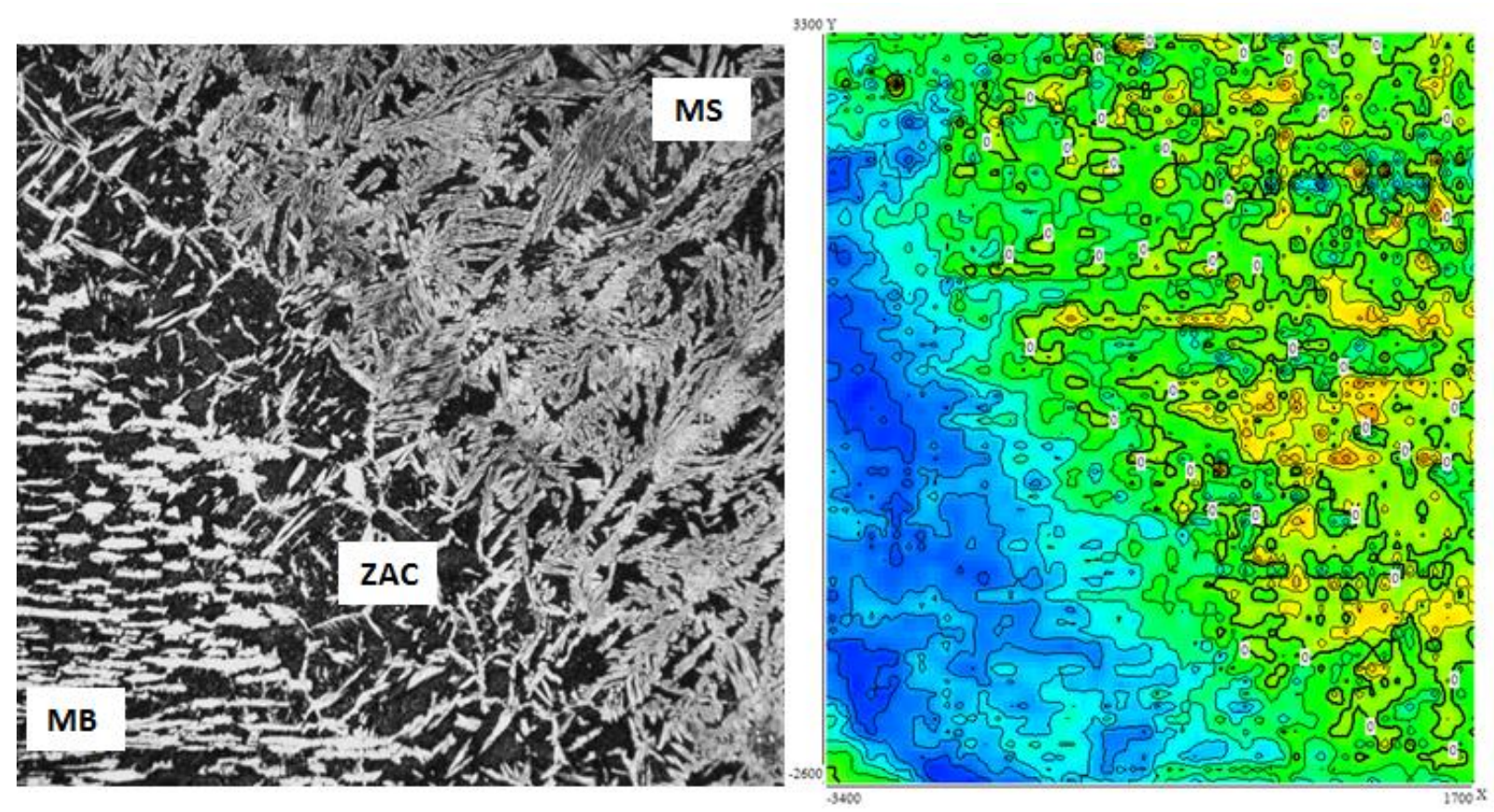

Figura 5.35: Imagem em 2D das densidades das correntes iônicas no CP1 $(A+A+C A)$ após 20h de ensaio.

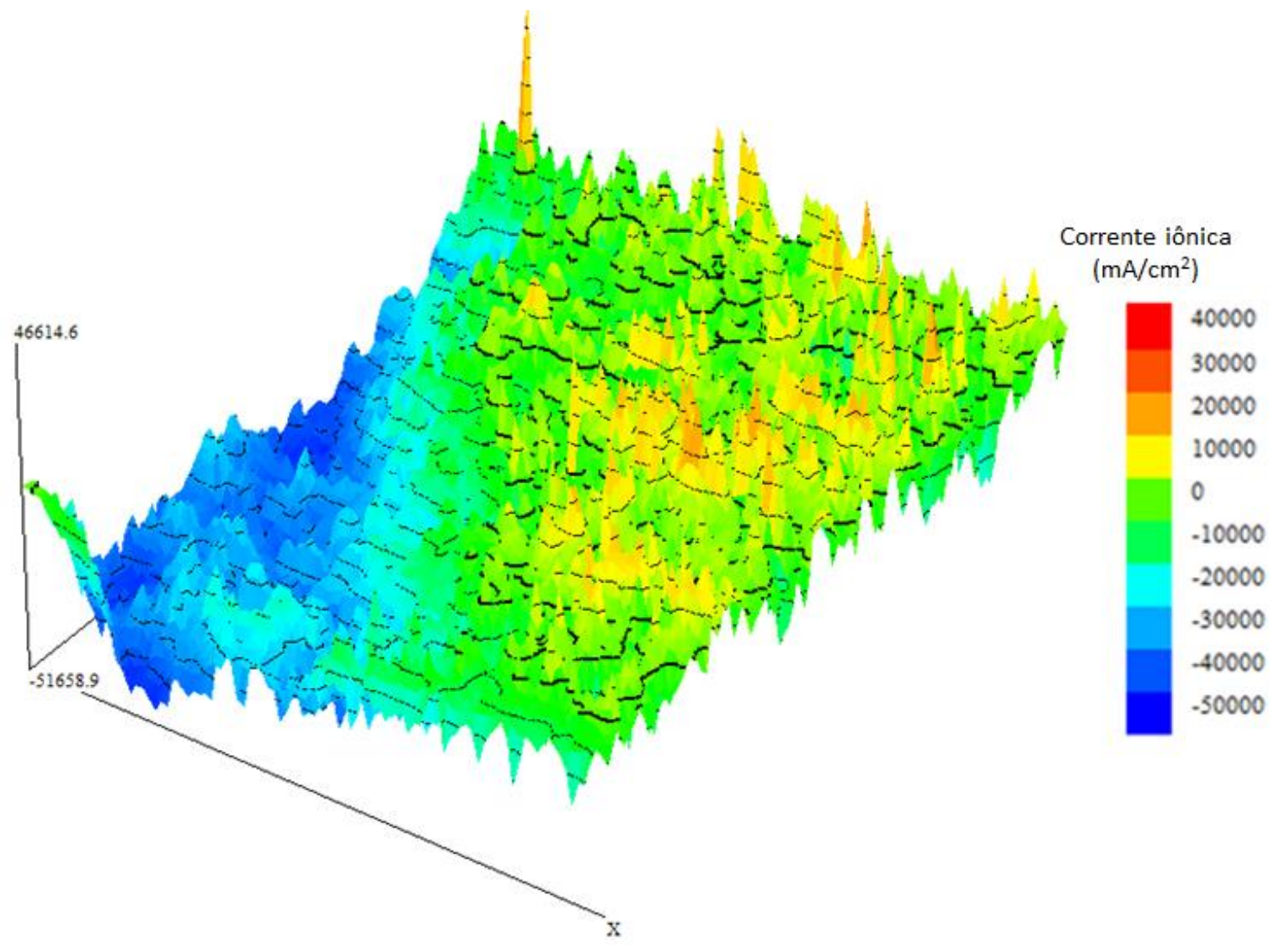

Figura 5.36: Imagem em 3D das densidades das correntes iônicas no CP1 $(A+A+C A)$ após 20h de ensaio. 

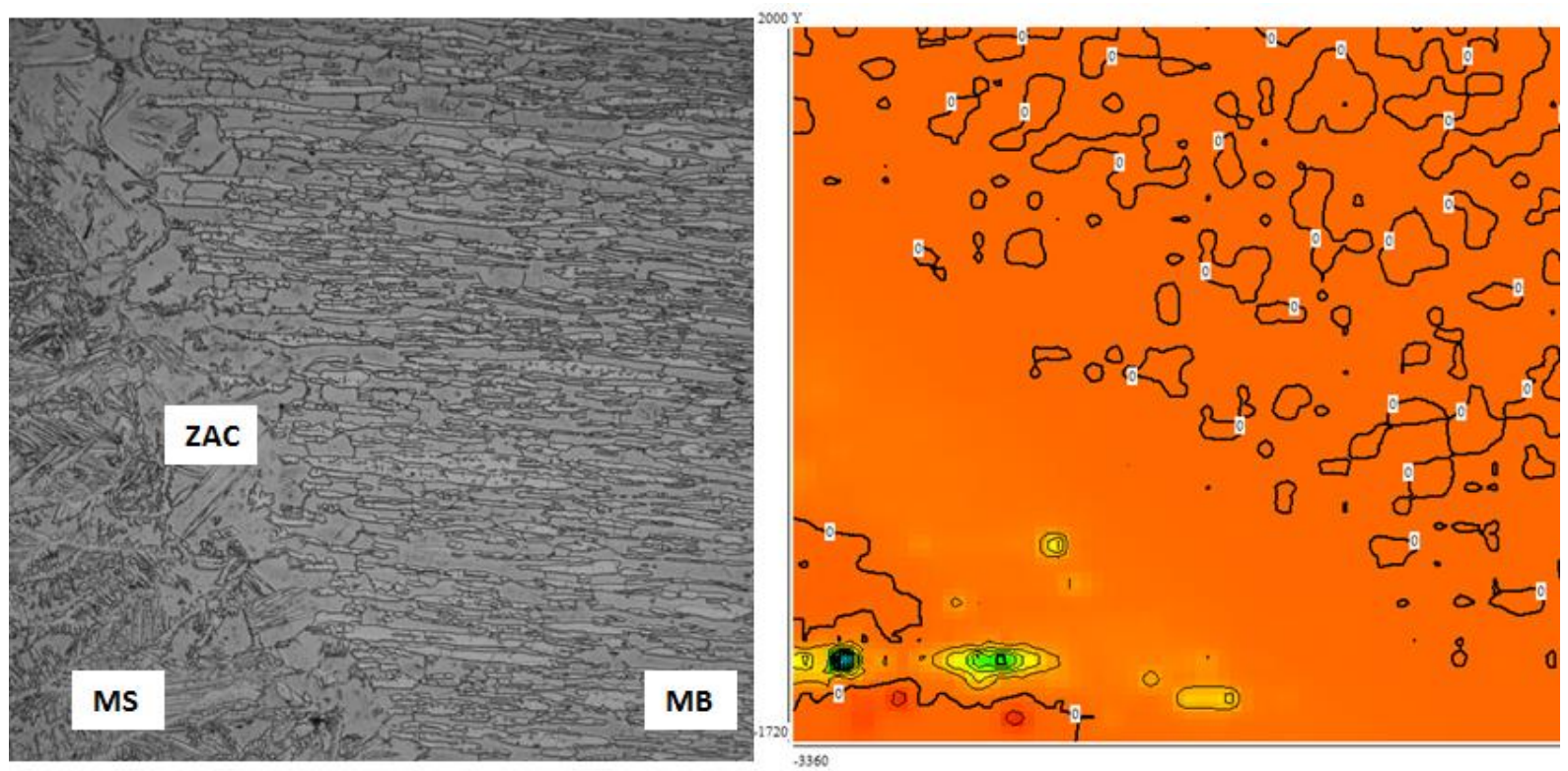

Figura 5.37: Imagem em 2D das densidades das correntes iônicas no CP2 $(B+B+C B)$ após $2 h$ de ensaio.

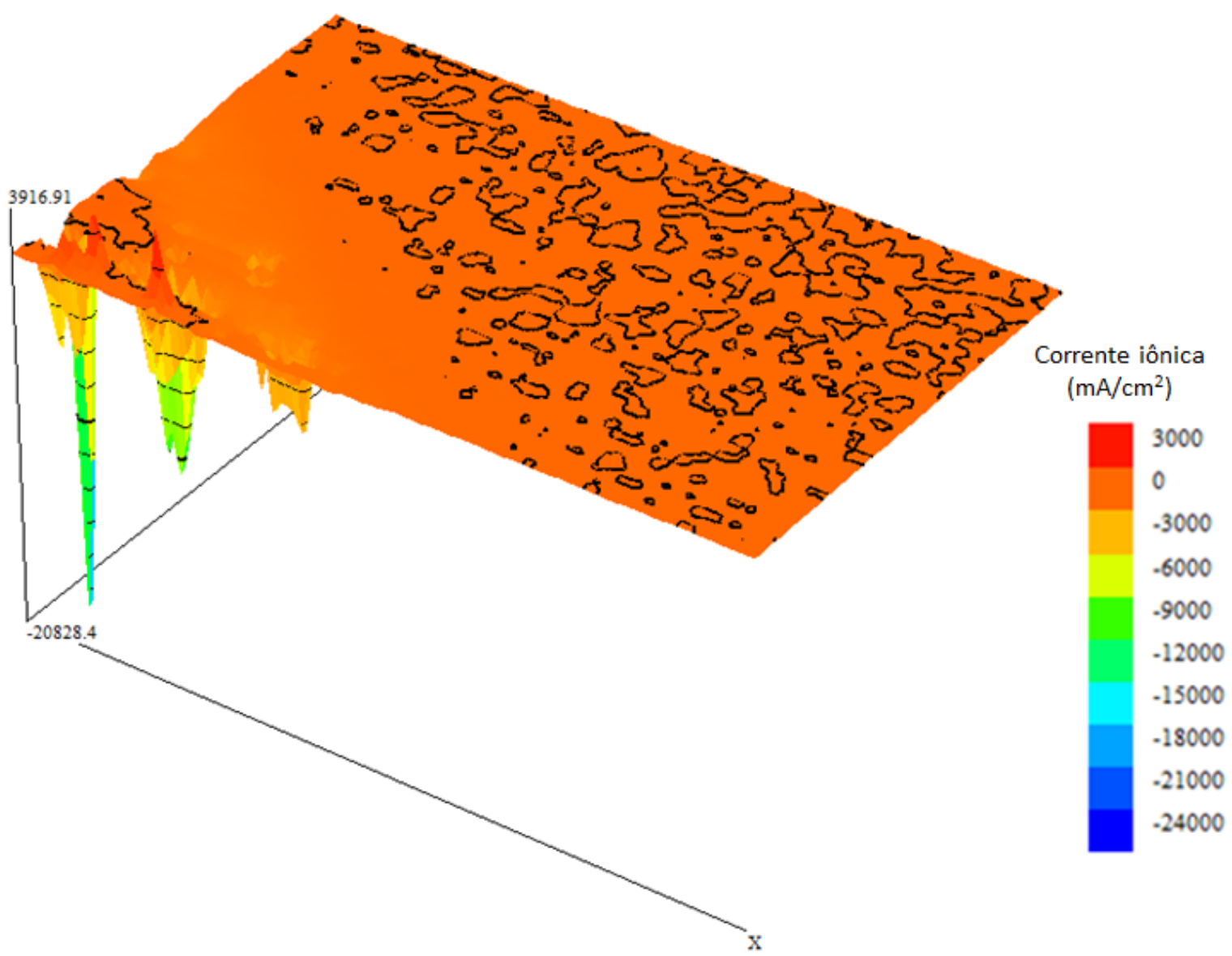

Figura 5.38: Imagem em 3D das densidades das correntes iônicas no CP2 (B+B+CB) após 2h de ensaio. 

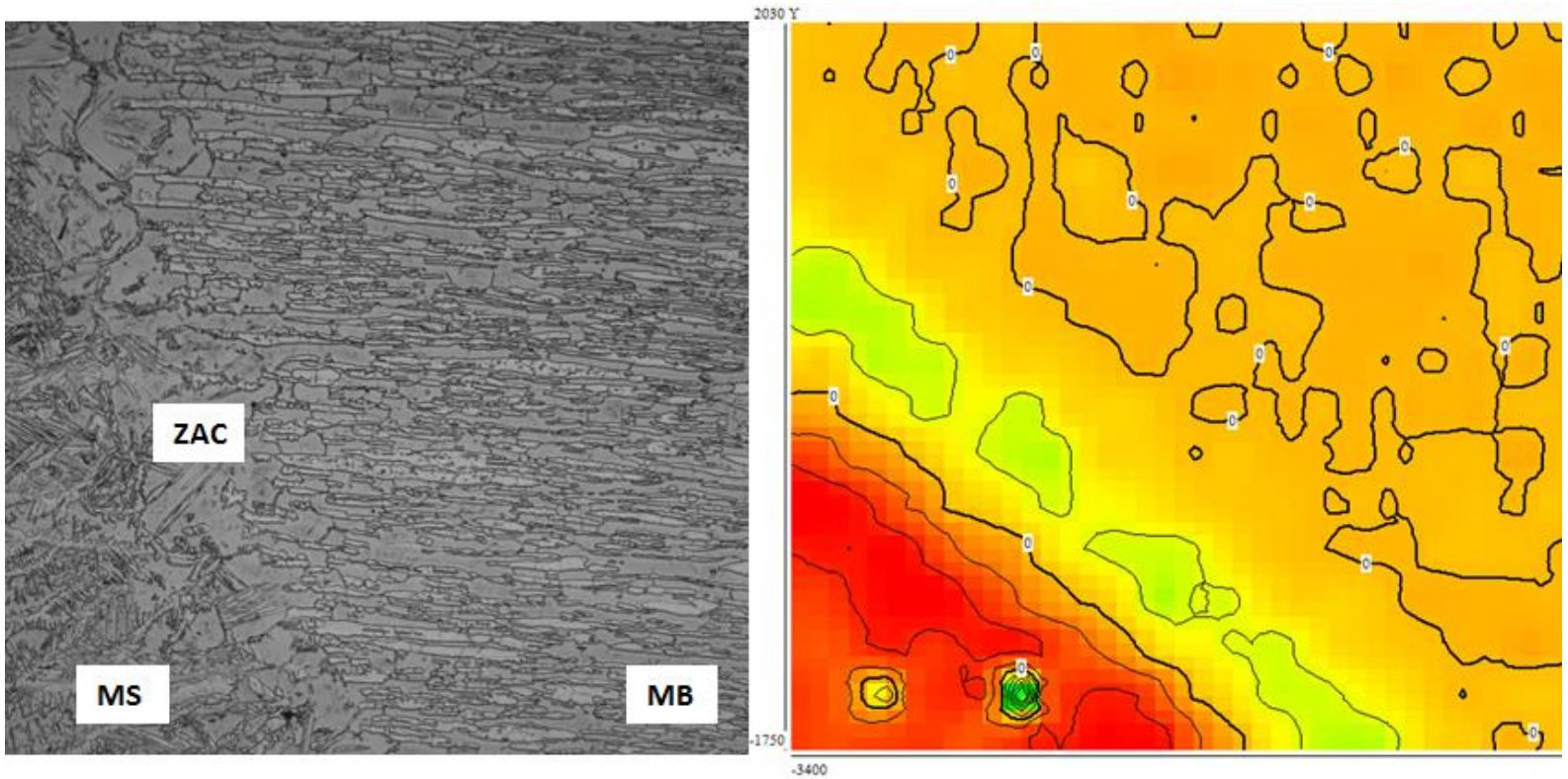

Figura 5.39: Imagem em 2D das densidades das correntes iônicas no CP2 $(B+B+C B)$ após 6 h de ensaio.

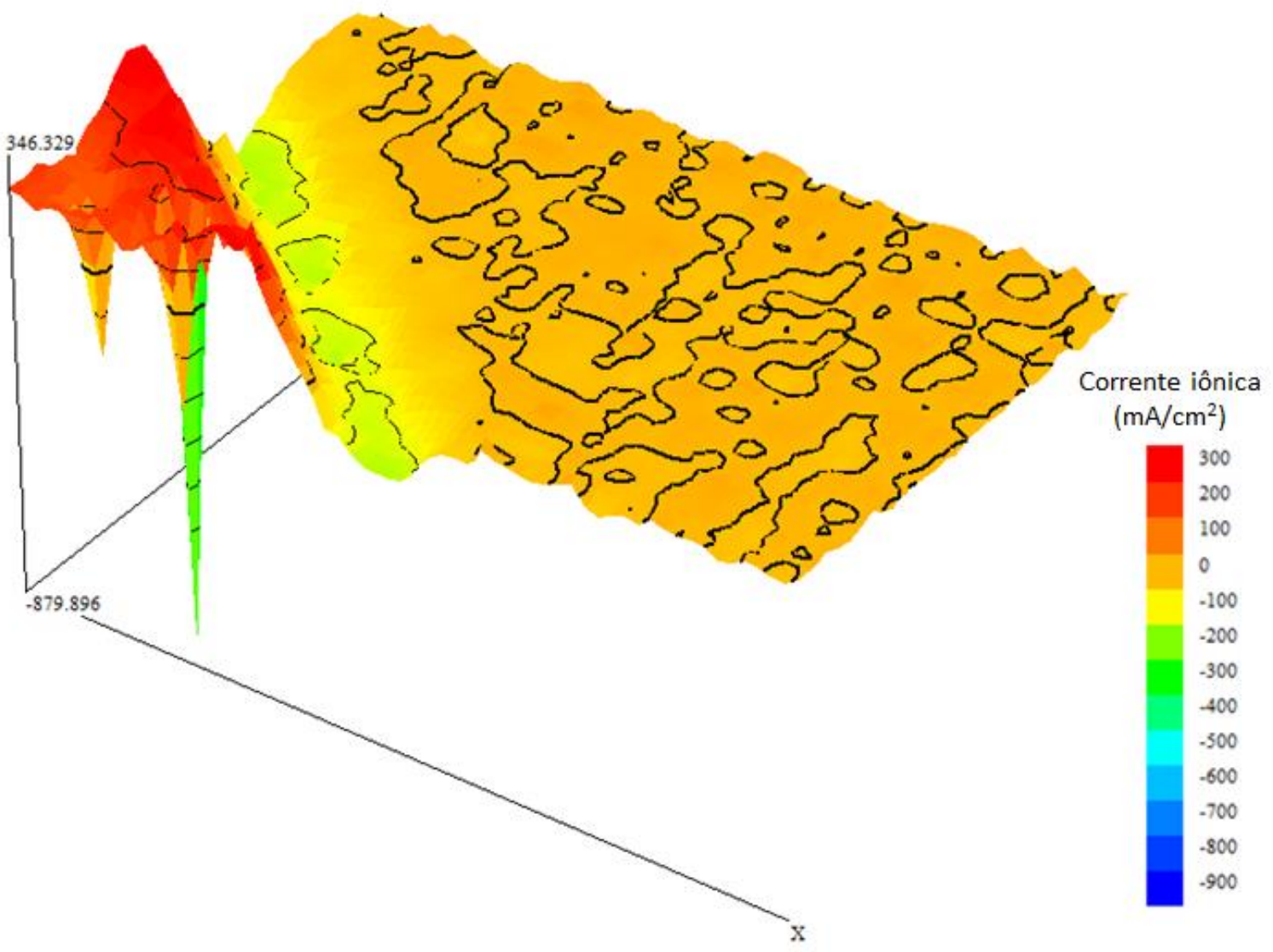

Figura 5.40: Imagem em 3D das densidades das correntes iônicas no CP2 (B+B+CB) após 6h de ensaio. 

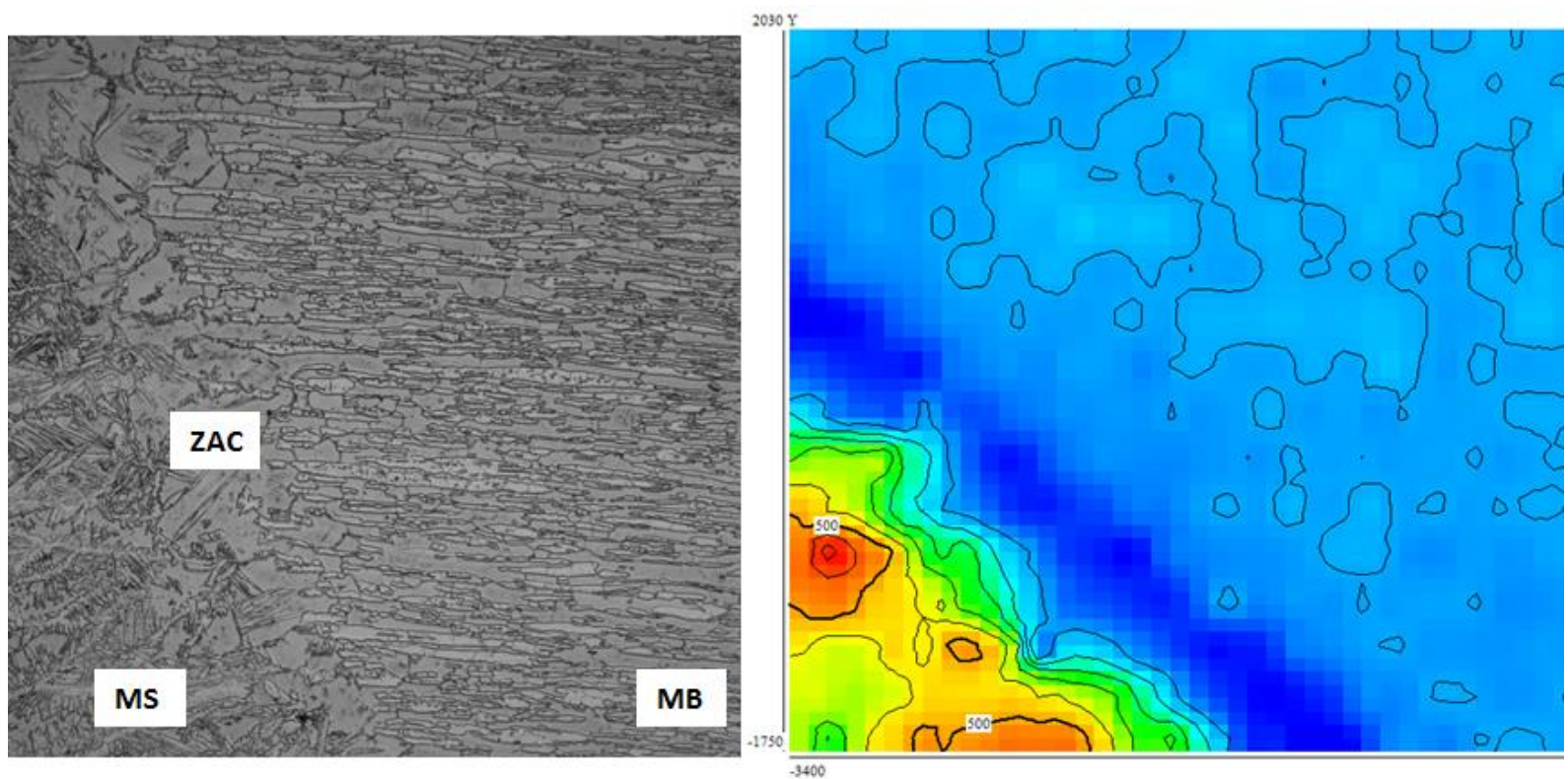

Figura 5.41: Imagem em 2D das densidades das correntes iônicas no CP2 ( $B+B+C B)$ após 20h de ensaio.

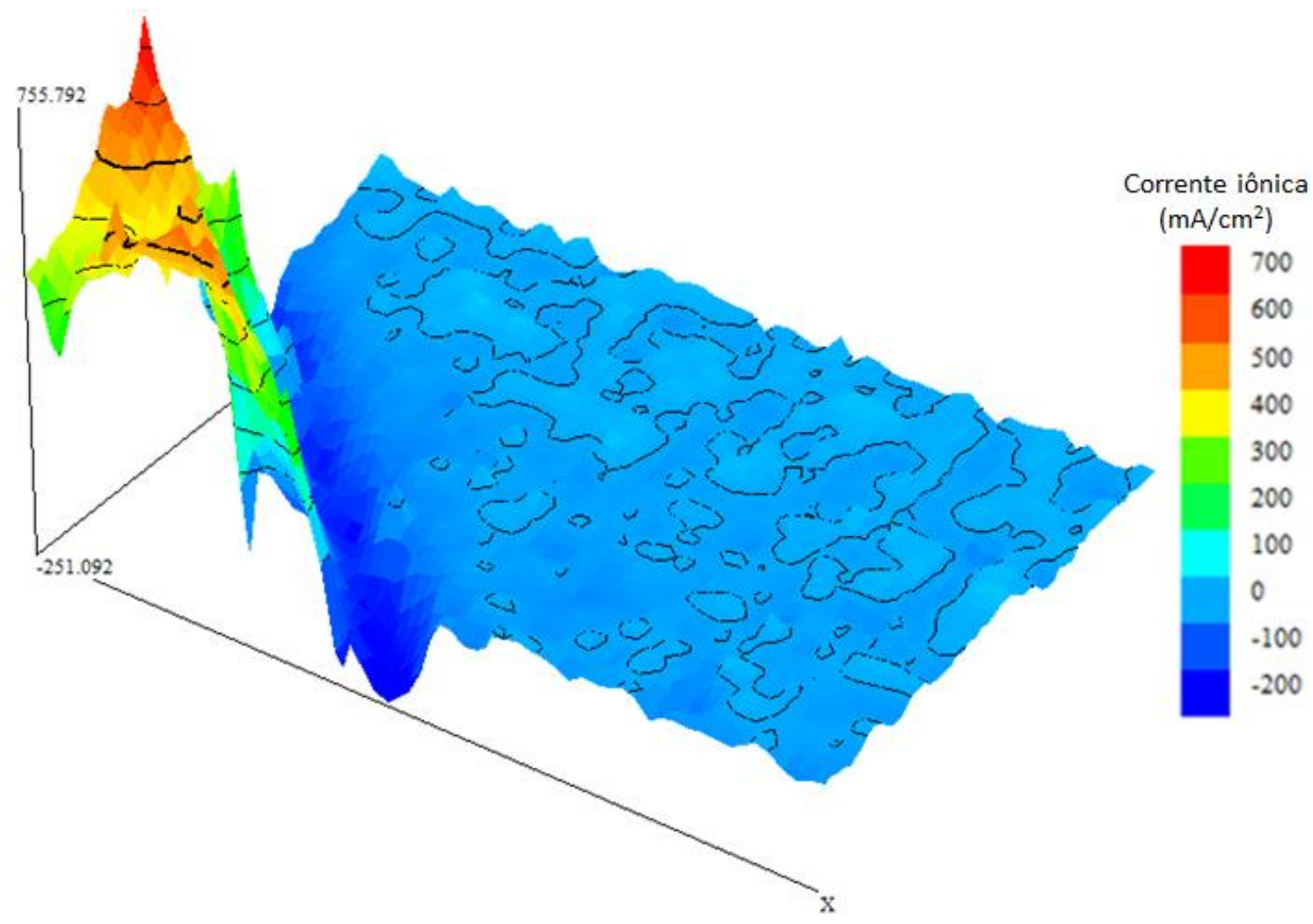

Figura 5.42: Imagem em 3D das densidades das correntes iônicas no CP2 ( $B+B+C B)$ após 20h de ensaio. 

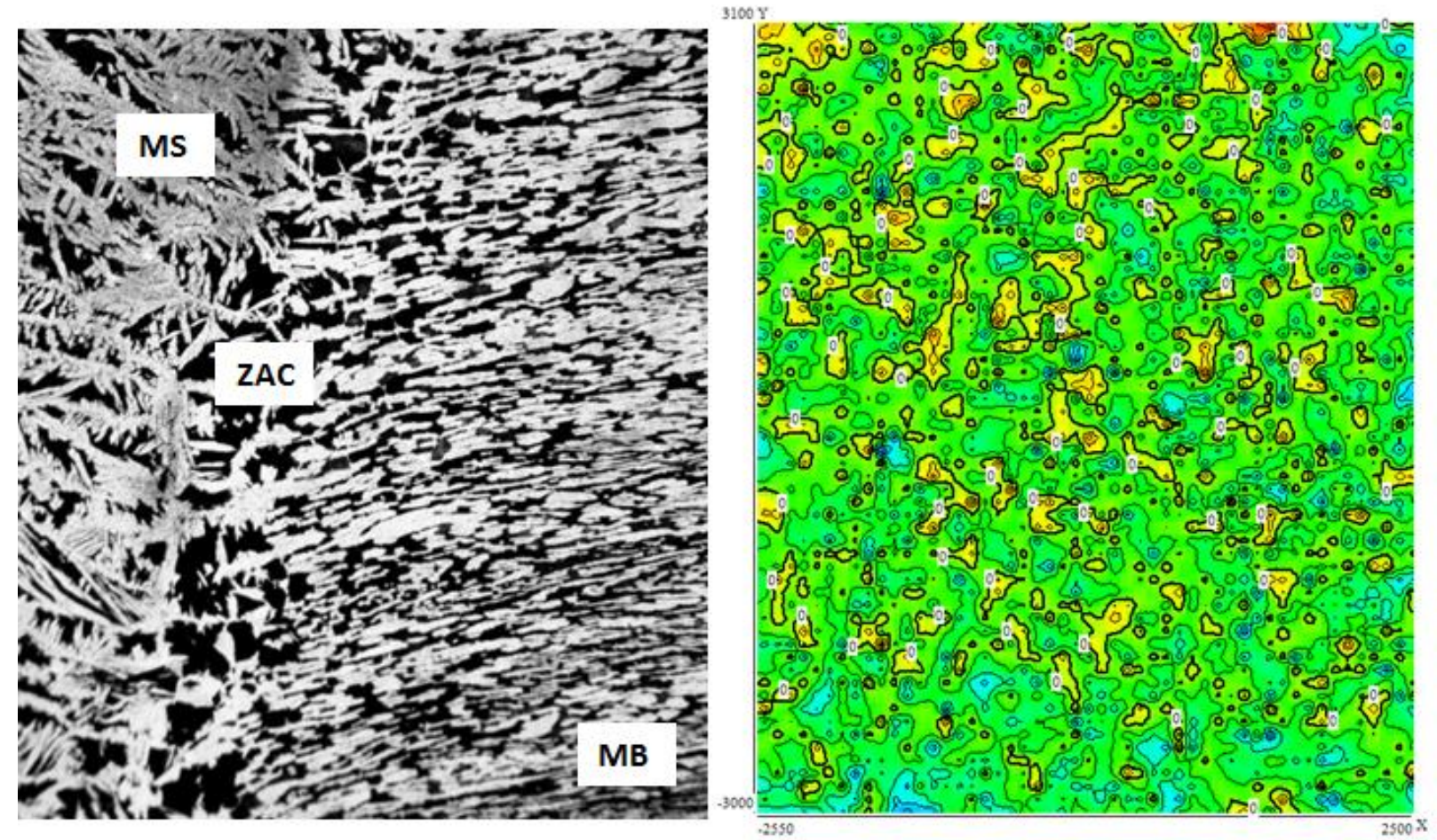

Figura 5.43: Imagem em 2D das densidades das correntes iônicas no CP5 $(A+B+C A)$ após $2 h$ de ensaio.



Figura 5.44: Imagem em 3D das densidades das correntes iônicas no CP5 $(A+B+C A)$ após 2h de ensaio. 



Figura 5.45: Imagem em 2D das densidades das correntes iônicas no CP5 ( $A+B+C A)$ após 6 h de ensaio.



Figura 5.46: Imagem em 3D das densidades das correntes iônicas no CP5 (A+B+CA) após 6h de ensaio. 

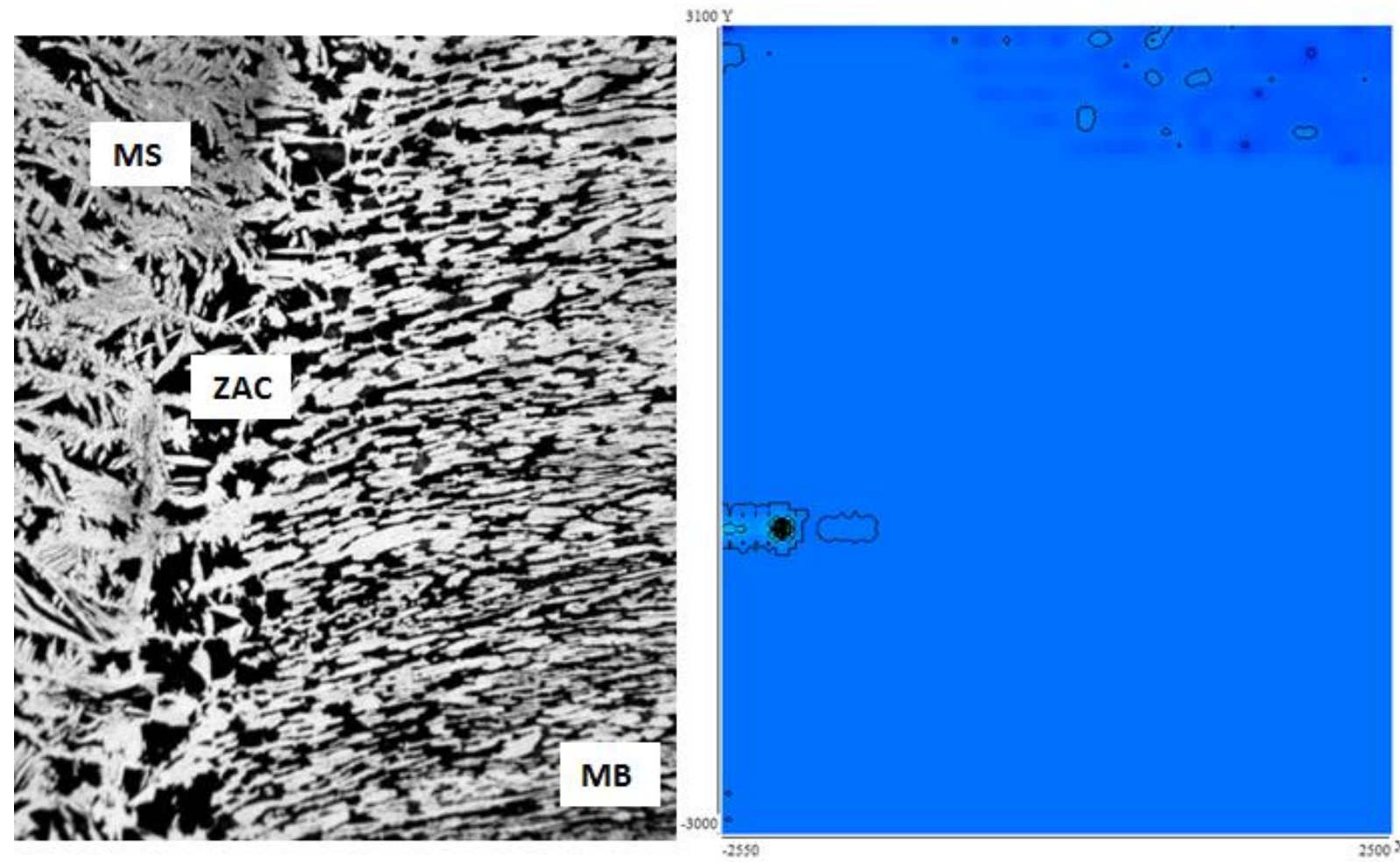

Figura 5.47: Imagem em 2D das densidades das correntes iônicas no CP5 $(A+B+C A)$ após 20h de ensaio.



Figura 5.48: Imagem em 3D das densidades das correntes iônicas no CP5 $(A+B+C A)$ após 20h de ensaio. 



Figura 5.49: Imagem em 2D das densidades das correntes iônicas no CP6 $(A+B+C B)$ após 2h de ensaio.

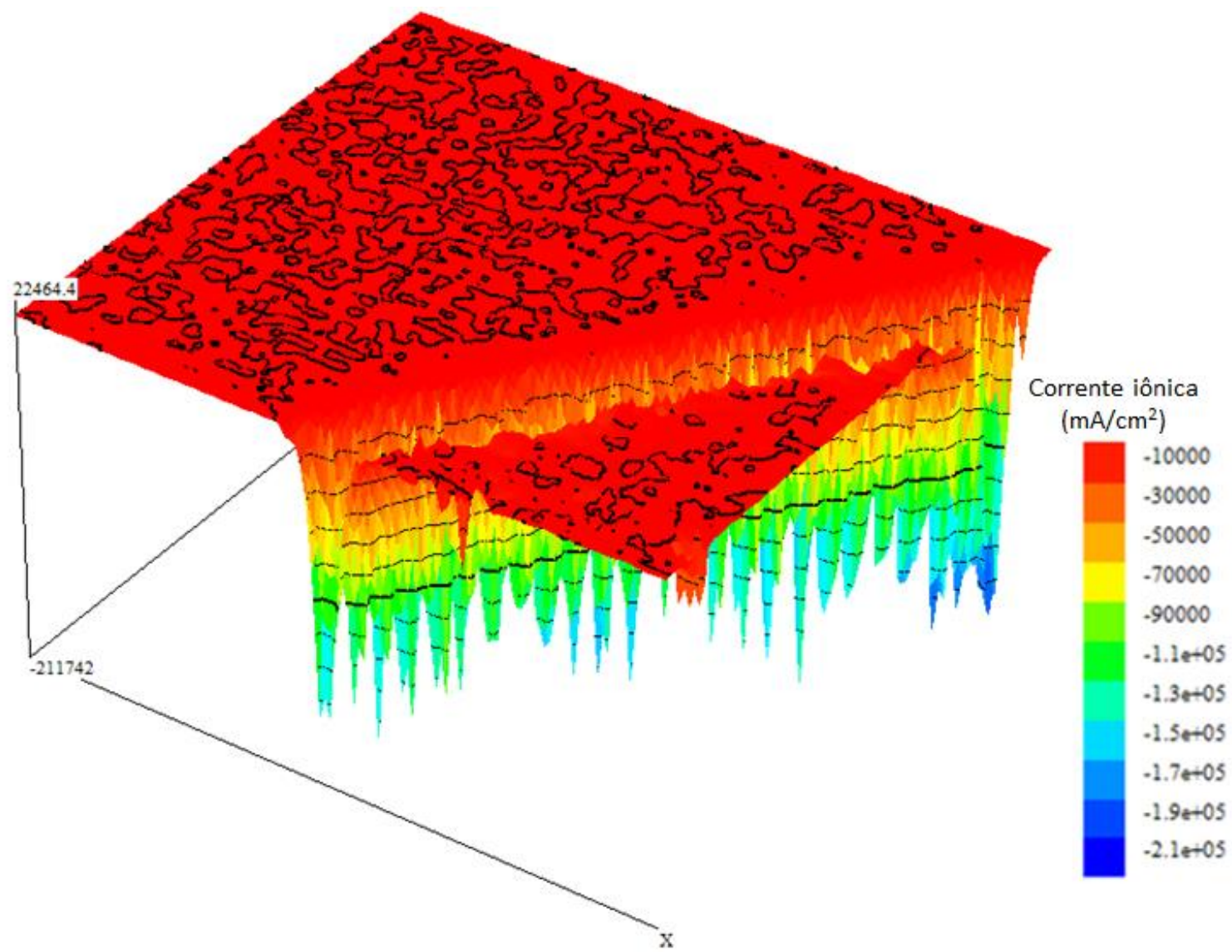

Figura 5.50: Imagem em 3D das densidades das correntes iônicas no CP6 ( $A+B+C B)$ após 2h de ensaio. 

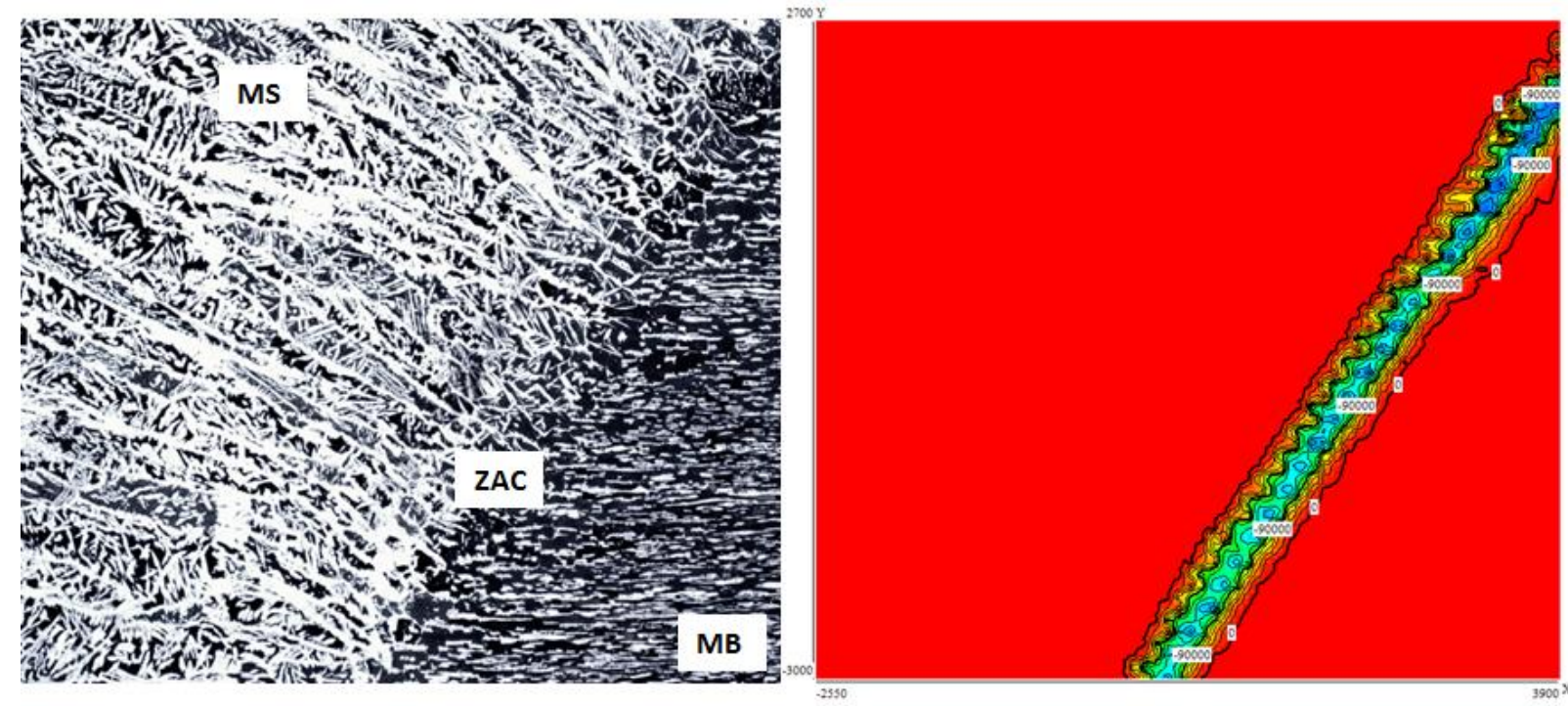

Figura 5.51: Imagem em 2D das densidades das correntes iônicas no CP6 $(A+B+C B)$ após 6 h de ensaio.

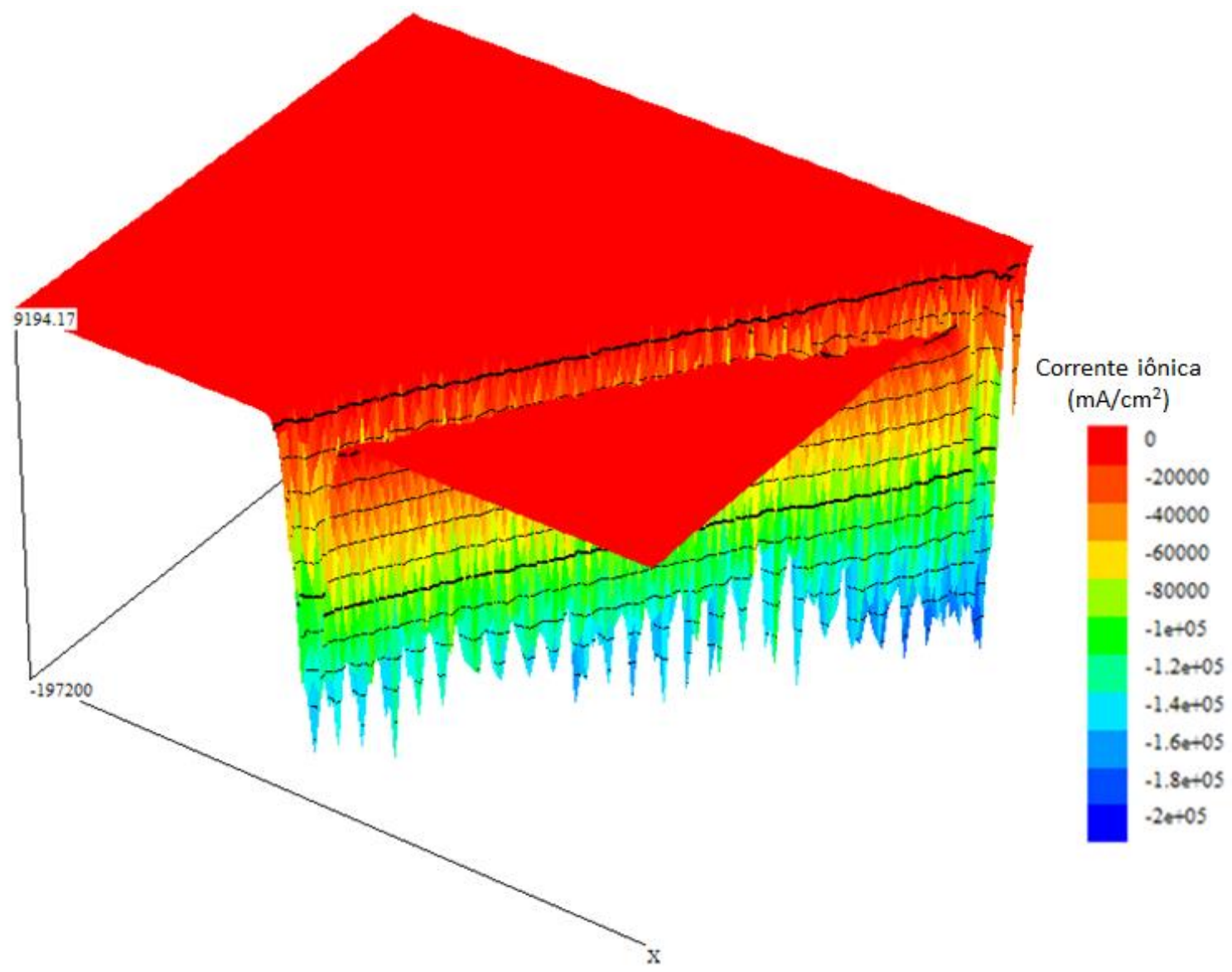

Figura 5.52: Imagem em 3D das densidades das correntes iônicas no CP6 $(A+B+C B)$ após 6 h de ensaio. 


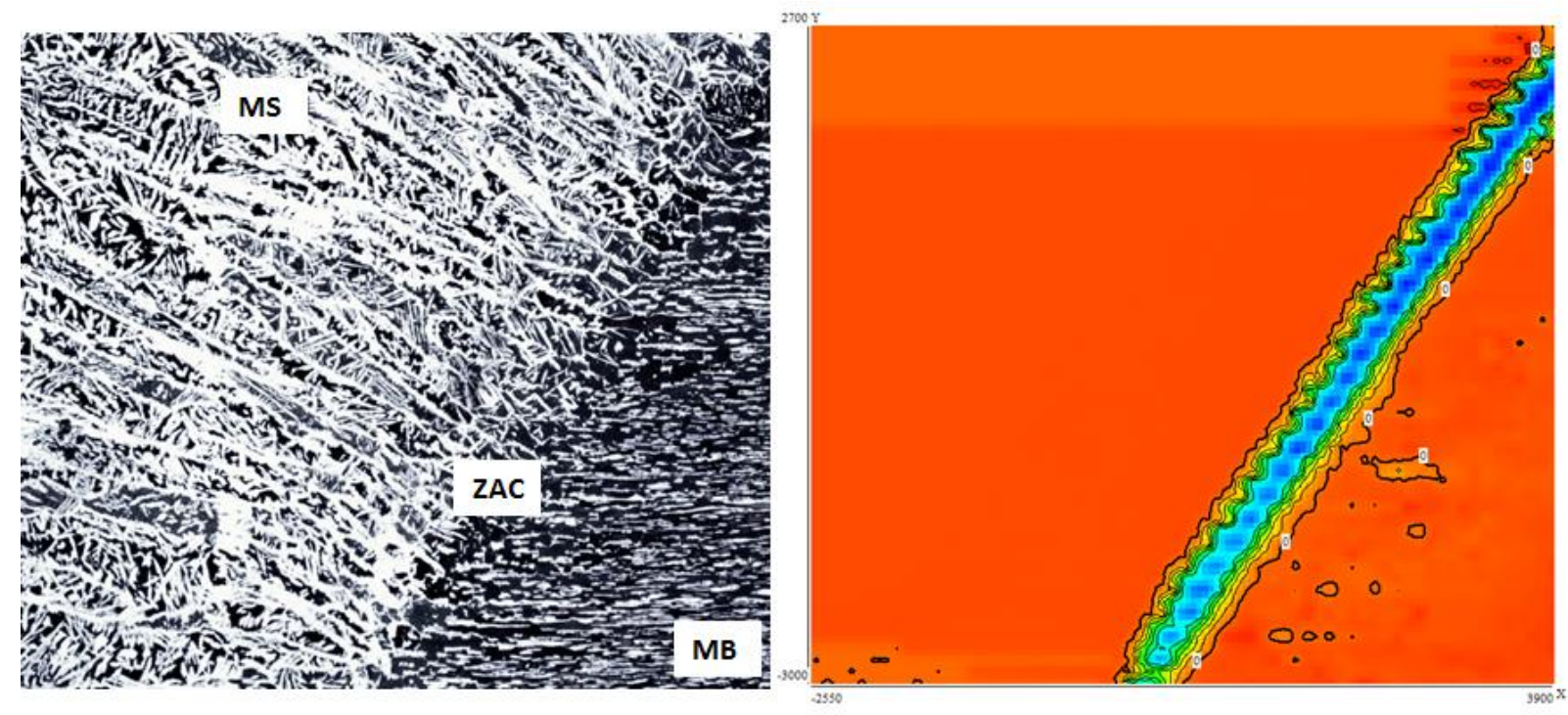

Figura 5.53: Imagem em 2D das densidades das correntes iônicas no CP6 ( $A+B+C B)$ após 20h de ensaio.



Figura 5.54: Imagem em 3D das densidades das correntes iônicas no CP6 $(A+B+C B)$ após 20h de ensaio. 


\section{DISCUSSÃO}

\subsection{PARÂMETROS DE SOLDAGEM}

Os valores das energias de soldagem são da ordem de $0,53 \pm 0,07 \mathrm{~kJ} / \mathrm{mm}$, o que representa uma discrepância de $14,1 \%$, e que apesar estarem dentro do intervalo admitido pela norma na qual este trabalho está baseado, Norsok M-601 ed. 2008, e das análises microestruturais das amostras não terem revelado diferenças significativas na microestrutura dos metais de solda e também nas ZAC, segundo Brandi $^{(1)}$, esta variação reflete-se no desempenho dos ensaios de impacto conforme valores apresentados na tabela 5.7 e figura 5.22 .

\subsection{CICLOS TÉRMICOS}

Ao analisar as taxas de resfriamento entre $1.200^{\circ} \mathrm{C}$ e $800^{\circ} \mathrm{C}$ percebe-se que o valor médio de $\Delta T_{12-8}$ é de $131,5 \pm 9,1{ }^{\circ} \mathrm{C} / \mathrm{s}$, o que representa uma discrepância de $3,8 \%$, ainda segundo Brandi $^{(1,2 \text { e 68) }}$ esta baixa variação na taxa de resfriamento reflete-se na fração volumétrica da ferrita na ZAC de 60,6 $\pm 2,8 \%$ e no metal de solda, que é de 40,6 $\pm 4,3 \%$, e encontram-se dentro dos limites normativos para o balanço das fases $\alpha$ e $\gamma$ de até 30 a 70\%, conforme item 4.3.6 da Norsok Standard M-601 ed. 2008.

\subsection{CARACTERIZAÇÃO MICROESTRUTURAL}

\subsubsection{MICROSCOPIA ÓTICA}

A análise dos corpos de prova através do microscópio ótico permitiu observar a transição entre os metais de base e os metais de solda, bem como as regiões da ZAC entre elas, e as mudanças de forma da austenita nestas regiões. Nas regiões dos metais de solda a predominância é de austenita de Widmanstatten, comum após processos que envolvam fusão e solidificação dos aços inoxidáveis superduplex, pode-se ver também, figuras 5.12 e 5.13 , pequenas porções de austenita secundária, bem como de nitretos de cromo, porém não foi possível observar a 
presença de fases deletérias, tais como a fase sigma e outras, que são de difícil detecção, contudo observou-se grande quantidade de micro inclusões de escória nas regiões dos metais de solda provenientes do fluxo utilizado nos consumíveis de soldagem, algo comum nos processos de soldagem com arame tubular.

\subsubsection{MICROSCOPIA ELETRÔNICA DE VARREDURA}

Uma vez que na análise dos corpos de prova através do microscópio ótico não se pode observar a presença de fases deletérias, tais como a fase sigma e outras, optou-se por analisar os corpos de prova através da microscopia eletrônica de varredura, desta forma manteve-se o trabalho dentro dos requisitos normativos da Norsok M-601, que não contemplam a análise por meio das técnicas de EBSD e DRX, porém foi possível utilizar o EDS que é capaz de identificar a composição química das áreas analisadas, e por ser a fase sigma rica em molibdênio, aproximadamente $11 \%$, foi feita uma varredura nos corpos de prova na tentativa de poder identificar esta fase. Após a varredura das amostras com a análise da composição química de inúmeras regiões onde se acreditou poder haver a presença de fases deletérias, não se identificou a presença destas fases, apenas observou-se a presença de nitretos e micro inclusões de escória como apresentado nas imagens do item 5.3 .2 e figuras de 6.1 e 6.2 . 


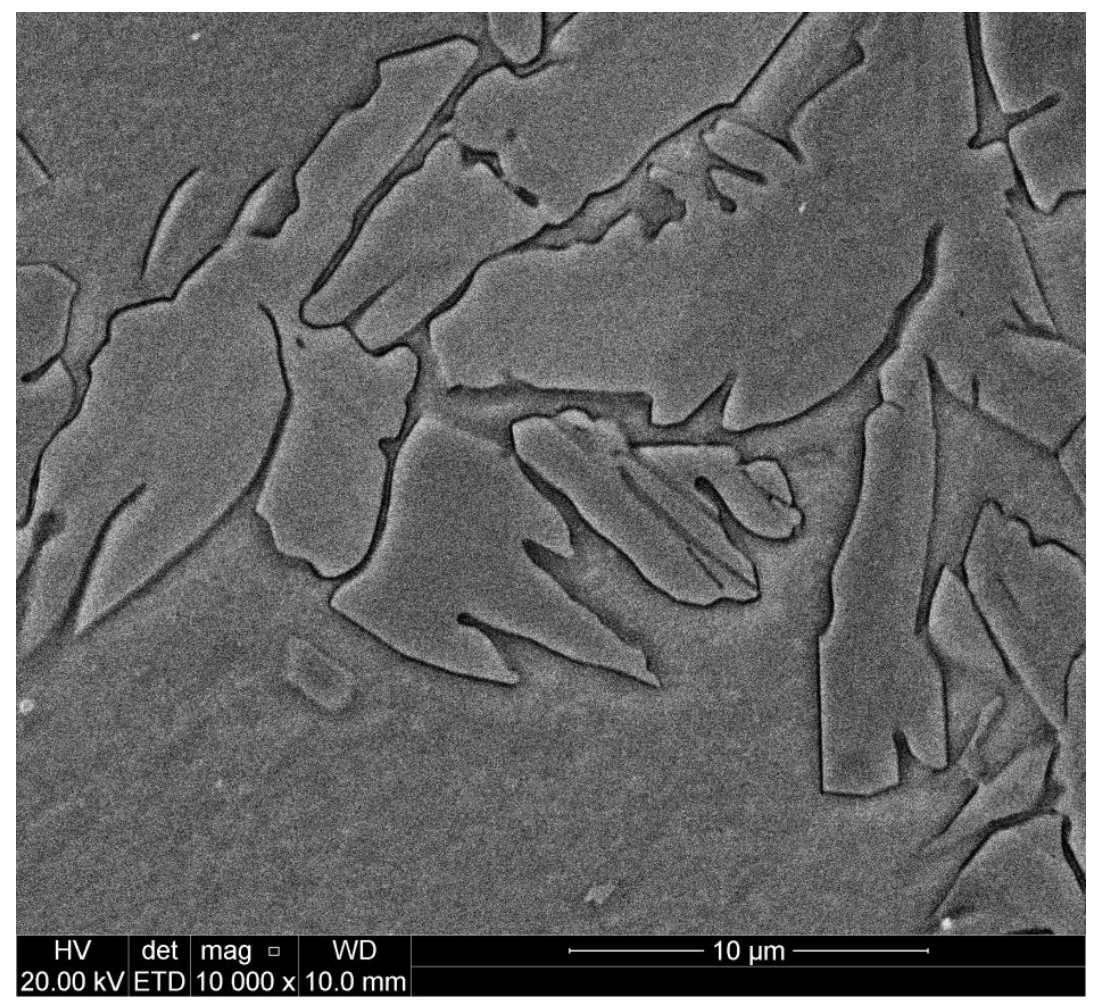

Figura 6.1: Metal de solda do CP4 ( $A+B+C B)$ com ampliação de $10.000 \mathrm{X}$, não é possível observar a presença de fases deletérias, apenas micro inclusões de escória.

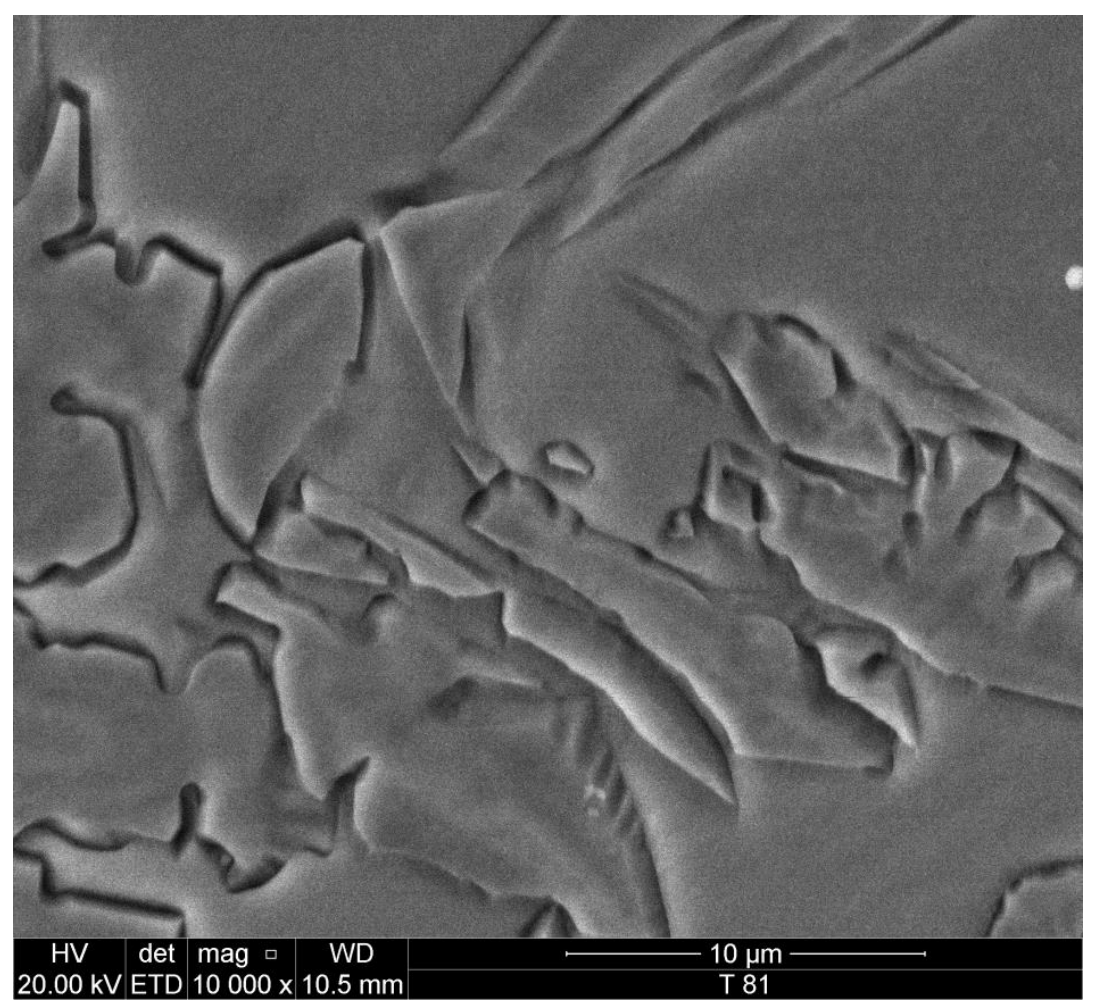

Figura 6.2: Metal de solda do CP7 $(A+B+C A)$ com ampliação de $10.000 X$, não é possível observar a presença de fases deletérias, apenas micro inclusões de escória. 
Com base no trabalho de Brandi $^{(67)}$ para identificação de fases intermetálicas em juntas soldadas de aços inoxidáveis superduplex, aplicação da prática $A$ da norma ASTM A 923, método para determinação de fases intermetálicas nos aços inoxidáveis duplex, e também prática $B$ que determina um valor mínimo teste de impacto Charpy a $-40^{\circ} \mathrm{C}$ de $30 \mathrm{~J}$ para o metal de solda e bem como a prática $\mathrm{C}$ que determina que a taxa de corrosão deva ser a inferior a $0,0001 \mathrm{~g} / \mathrm{cm}^{2}$ para o ensaio de corrosão conforme ASTM A G-48, e face ao desempenho nos testes de impacto figura 6.3 e de corrosão dos corpos de prova das soldagens dissimilares tabela 5.10, pode-se afirmar que as juntas soldadas estão livres de fases intermetálicas ou se houver a quantidade é desprezível.

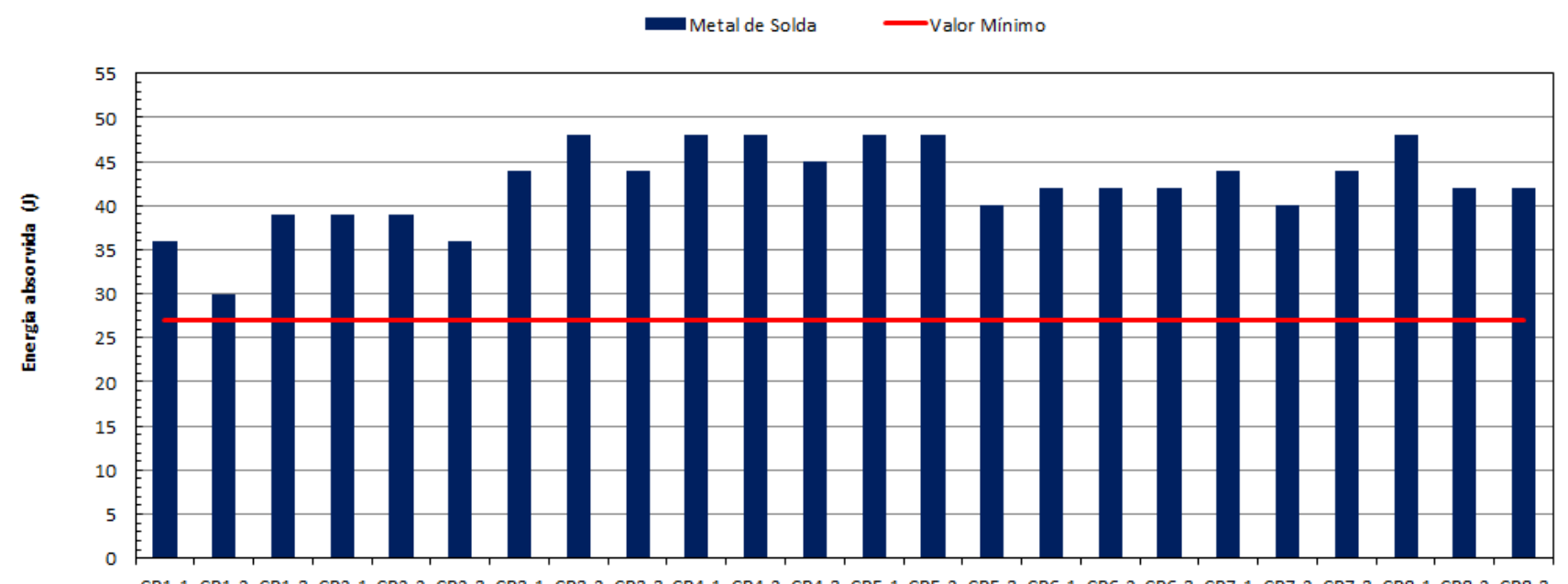

Figura 6.3: Resultados individuais do ensaio de impacto Charpy $-\mathrm{V}$ a $-46^{\circ} \mathrm{C}$ na região do metal de solda.

Contudo fica evidente que existe a necessidade da realização dos ensaios de EBSD e DRX, de forma complementar, para a identificação precisa destas fases.

\subsubsection{FRAÇÃO VOLUMÉTRICA DA FERRITA}

A variação da fração volumétrica da ferrita na ZAC de $60,6 \pm 2,8 \%$ e no metal de solda, que é de $40,6 \pm 4,3 \%$, manteve-se dentro dos limites desejados de 30 a $70 \%$, conforme item 4.3.6 da Norsok Standard M-601 ed. 2008, o fato das taxas de resfriamento entre $1.200{ }^{\circ} \mathrm{C}$ e $800 \stackrel{\circ}{\circ} \mathrm{C}$ terem sido elevadas, com $\Delta \mathrm{T}_{12-8}$ médio de 
$131,5 \pm 9,1 \stackrel{\circ}{\circ} \mathrm{C} / \mathrm{s}$ colaborou para manter o balanço das fases dentro dos limites esperados.

\subsection{ENSAIOS NÃO DESTRUTIVOS}

O exame visual dos corpos de prova não indicou falhas nas soldas, bem como não foram detectadas trincas ou poros externos no ensaio com o líquido penetrante, e com base nestes ensaios as soldagens foram consideradas adequadas.

\subsection{ENSAIOS DESTRUTIVOS}

\subsubsection{ENSAIO DE IMPACTO - CHARPY $-46^{\circ} \mathrm{C}$}

Apesar de todos os corpos de prova atendem ao requisito normativo para o ensaio de impacto, foi realizado o cálculo da variância com o intuito de comparar as variações de resistência ao impacto das amostras, após o cálculo da variância, com $5 \%$ de significância, constatou-se que o valor de " $F$ " é maior que o valor de " $F$ " crítico, indicativo de que deve existir pelo menos uma amostra diferente das demais. Para identificar quais das amostras são diferentes entre si foi aplicado o teste de Tukey para comparação das médias da análise de variância, e foi calculado o valor da diferença mínima significativa (DMS) e comparada com a diferença entre as médias das amostras, que devem ser menores, em módulo, que o valor da diferença mínima significativa (DMS). As amostras com diferença entre suas médias maior, em módulo, que o valor da diferença mínima significativa (DMS) são consideradas diferentes $^{(65,76,77,78)}$.

Os valores calculados das variâncias, das médias e da diferença mínima significativa (DMS) para cada um dos corpos de prova dos metais de solda e das ZAC estão apresentados nas tabelas 6.1 e 6.2 . 
Tabela 6.1: Cálculo da variância dos resultados do ensaio Charpy $-\mathrm{V}-46{ }^{\circ} \mathrm{C}$ dos metais de solda.

\begin{tabular}{|c|c|c|c|c|c|c|c|c|}
\hline Amostra MS & CP1 & CP2 & CP3 & CP4 & CP5 & CP6 & CP7 & CP8 \\
\hline $\mathbf{x 1}$ & 36,0 & 39,0 & 44,0 & 48,0 & 48,0 & 42,0 & 44,0 & 48,0 \\
\hline $\mathbf{x 2}$ & 30,0 & 39,0 & 48,0 & 48,0 & 48,0 & 42,0 & 40,0 & 42,0 \\
\hline $\mathbf{x 3}$ & 39,0 & 36,0 & 44,0 & 45,0 & 40,0 & 42,0 & 44,0 & 42,0 \\
\hline Soma & 105,0 & 114,0 & 136,0 & 141,0 & 136,0 & 126,0 & 128,0 & 132,0 \\
\hline Média & 35,0 & 38,0 & 45,3 & 47,0 & 45,3 & 42,0 & 42,7 & 44,0 \\
\hline Variância & 21,0 & 3,0 & 5,3 & 3,0 & 21,3 & 0,0 & 5,3 & 12,0 \\
\hline Fonte da variação & SQ & Gl & MQ & $\mathbf{F}$ & valor-P & $\mathbf{F ~ c r i ́ t i c o ~}$ & & DMS \\
\hline Entre grupos & 345,833 & 7,0 & 49,4048 & 5,5667 & 0,00217 & 2,6572 & & 8,652 \\
\hline Dentro dos grupos & 142,0 & 16,0 & 8,875 & & & & & \\
\hline & & & & & & & & \\
\hline Total & 487,833 & 23,0 & & & & & & \\
\hline
\end{tabular}

Realizada a verificação entre as médias das amostras, nota-se que os valores de absorção de energia de impacto dos metais de solda dos corpos de prova dissimilares possuem variações pequenas em suas médias, e com significância de $5 \%$, podemos afirmar que as amostras CP3, CP4, CP5, CP6, CP7 e CP8 são iguais entre si. Porém os valores de absorção de energia de impacto dos metais de solda dos corpos de prova similares, CP1 e CP2, possuem variações maiores em suas médias, e apesar de serem iguais entre si, com significância de $5 \%$, diferem dos corpos de prova dissimilares. Esse fato se deve aos defeitos internos em suas soldas que não foram detectados antes da realização dos ensaios destrutivos, conforme descrito no item 5.5.2, tabela 5.8 e figuras de 5.25 a 5.28 .

Tabela 6.2: Cálculo da variância dos resultados do ensaio Charpy $-\mathrm{V}-46^{\circ} \mathrm{C}$ das ZAC.

\begin{tabular}{|c|c|c|c|c|c|c|c|c|}
\hline Amostra ZAC & CP1 & CP2 & CP3 & CP4 & CP5 & CP6 & CP7 & CP8 \\
\hline $\mathbf{x 1}$ & 63,0 & 60,0 & 88,0 & 57,0 & 76,0 & 53,0 & 52,0 & 84,0 \\
\hline $\mathbf{x 2}$ & 39,0 & 72,0 & 88,0 & 87,0 & 76,0 & 75,0 & 44,0 & 108,0 \\
\hline $\mathbf{x 3}$ & 72,0 & 45,0 & 56,0 & 63,0 & 68,0 & 69,0 & 68,0 & 93,0 \\
\hline Soma & 174,0 & 177,0 & 232,0 & 207,0 & 220,0 & 197,0 & 164,0 & 285,0 \\
\hline Média & 58,0 & 59,0 & 77,3 & 69,0 & 73,3 & 65,7 & 54,7 & 95,0 \\
\hline Variância & 291,0 & 183,0 & 341,3 & 252,0 & 21,3 & 129,3 & 149,3 & 147,0 \\
\hline Fonte da variação & $\mathbf{S Q}$ & $\mathbf{g l}$ & $\mathbf{M Q}$ & $\mathbf{F}$ & valor-P & $\mathbf{F ~ c r i ́ t i c o ~}$ & & DMS \\
\hline Entre grupos & 3605,3 & 7,0 & 515,048 & 2,7209 & 0,04612 & 2,6572 & & 8,652 \\
\hline Dentro dos grupos & 3028,7 & 16,0 & 189,3 & & & & & \\
\hline & & & & & & & & \\
\hline Total & 6634,0 & 23,0 & & & & & & \\
\hline
\end{tabular}


Realizada a verificação entre as médias das amostras dos corpos de prova dissimilares, nota-se que os valores de absorção de energia de impacto das ZAC possuem variações maiores em suas médias, e formam três grupos distintos, e com significância de $5 \%$ podemos afirmar que as amostras CP1, CP2, CP6 CP7 são iguais entre si e diferentes das demais, e que as amostras CP3, CP4 e CP5 são iguais entre si e diferentes das demais, e por último o CP8 difere de todos. Esta diferença entre as amostras se deve ao fato da ZAC ser uma faixa estreita com, pouco mais de um $1 \mathrm{~mm}$, e mesmo com a utilização de chanfro em meio "V" não se obteve uma ZAC perpendicular ao plano da chapa, conforme figura 6.4, e logo a região do impacto abrangeu partes do metal de base e partes do metal de solda, 0 que ficou evidente após analise dos valores obtidos neste ensaio.

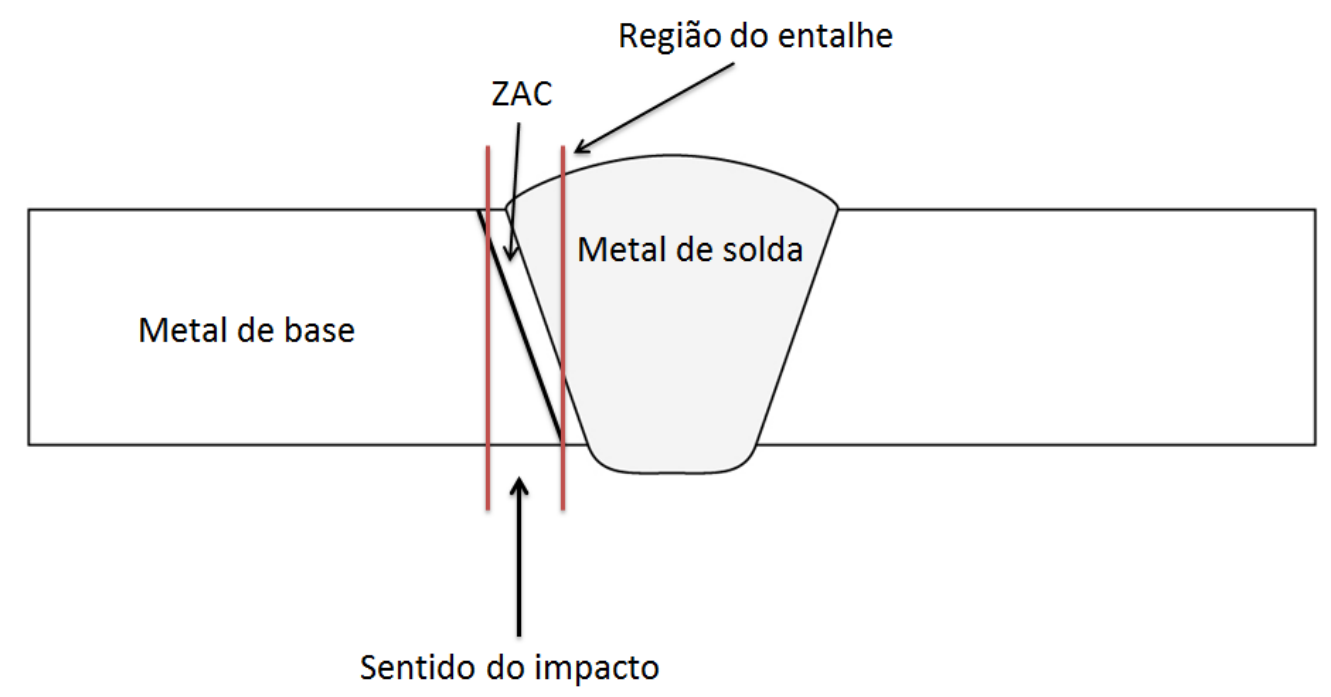

Figura 6.4 Imagem representativa da região submetida ao ensaio de impacto para a ZAC.

\subsubsection{ENSAIO DE TRAÇÃO CONFORME ASME IX QW-150}

Apesar de todos os corpos de prova das soldagens dissimilares atendem ao requisito normativo para o ensaio de tração, que determina que a ruptura deva acontecer na região do metal de base, de acordo com Brandi ${ }^{(1)}$, é possível que nas regiões onde se deu a ruptura possa ter se iniciado o processo de fragilização a 475 ${ }^{\circ} \mathrm{C}$, uma vez que essas regiões foram expostas à temperaturas próximas deste valor, e para tanto foi verificada a temperatura a que a região da fratura foi exposta por ocasião da soldagem, também foi feita a medição de dureza da ferrita nas regiões 
adjacentes, anterior e posterior, à região de ruptura, a $8 \mathrm{~mm}$ e $16 \mathrm{~mm}$ de distância da linha de fusão, para comparação com a dureza dos metais de base, tabela 6.3.

Tabela 6.3: Medição de dureza da ferrita a $8 \mathrm{~mm}$ e $16 \mathrm{~mm}$ da linha da fusão

\begin{tabular}{|c|c|c|c|c|c|}
\hline Corpos & Referência & Lado & $\begin{array}{c}\text { Temperatura } \\
\left({ }^{\circ} \mathbf{C}\right)\end{array}$ & $\begin{array}{c}\text { Distância LF } \\
(\mathrm{mm})\end{array}$ & $\begin{array}{c}\text { Dureza } \\
\text { HV }=0,01\end{array}$ \\
\hline CP1 & $A+A+C A$ & UNS S32750 & de fusão & Metal Base & $307,2 \pm 9,2$ \\
\hline CP2 & $\mathrm{B}+\mathrm{B}+\mathrm{CB}$ & UNS S32760 & de fusão & Metal Base & $302,0 \pm 9,2$ \\
\hline \multirow{2}{*}{ CP3 } & \multirow{2}{*}{$\mathrm{A}+\mathrm{B}+\mathrm{CA}$} & \multirow{2}{*}{ UNS S32750 } & \multirow[t]{2}{*}{350} & 8 & $226,5 \pm 39,8$ \\
\hline & & & & 16 & $252,8 \pm 39,9$ \\
\hline \multirow{2}{*}{$\mathrm{CP} 4$} & \multirow{2}{*}{$A+B+C B$} & \multirow{2}{*}{ UNS S32750 } & \multirow[t]{2}{*}{482} & 8 & $271,0 \pm 12,4$ \\
\hline & & & & 16 & $339,8 \pm 21,3$ \\
\hline \multirow{2}{*}{ CP5 } & \multirow{2}{*}{$\mathrm{A}+\mathrm{B}+\mathrm{CA}$} & \multirow{2}{*}{ UNS S32760 } & \multirow[t]{2}{*}{520} & 8 & $297,0 \pm 17,6$ \\
\hline & & & & 16 & $319,2 \pm 31,2$ \\
\hline \multirow{2}{*}{ CP6 } & \multirow{2}{*}{$A+B+C B$} & \multirow{2}{*}{ UNS S32760 } & \multirow[t]{2}{*}{495} & 8 & $277,0 \pm 20,8$ \\
\hline & & & & 16 & $331,4 \pm 13,4$ \\
\hline \multirow{2}{*}{$\mathrm{CP} 7$} & \multirow{2}{*}{$\mathrm{A}+\mathrm{B}+\mathrm{CA}$} & \multirow{2}{*}{ UNS S32750 } & \multirow[t]{2}{*}{480} & 8 & $299,0 \pm 9,2$ \\
\hline & & & & 16 & $344,6 \pm 15,5$ \\
\hline \multirow{2}{*}{ CP8 } & \multirow{2}{*}{$A+B+C B$} & \multirow{2}{*}{ UNS S32750 } & \multirow[t]{2}{*}{470} & 8 & $300,0 \pm 13,3$ \\
\hline & & & & 16 & $287,8 \pm 10,6$ \\
\hline
\end{tabular}

Ao comparar as durezas da ferrita, medidas a $8 \mathrm{~mm}$ e $16 \mathrm{~mm}$ de distância da linha de fusão, com as durezas dos metais de base percebe-se que nas regiões onde as temperaturas atingidas foram mais elevadas as durezas também foram maiores, superando em alguns casos os valores obtidos para os metais de base. Este fato é um indicador de que algumas regiões possam ter sido fragilizadas pelo aquecimento, fragilização a $475^{\circ} \mathrm{C}$, conforme descrito por Brandi ${ }^{(1)}$.

Foi feita a análise estatística dos valores obtidos neste ensaio utilizando-se a mesma metodologia utilizada para analisar os resultados do ensaio de impacto, conforme item 6.5.1. Após o cálculo da variância, com $5 \%$ de significância, constatou-se que o valor de "F" é maior que o valor de "F" crítico, indicativo de que deve existir pelo menos uma amostra diferente das demais. Para identificar quais das amostras são diferentes entre si foi aplicado o teste de Tukey para comparação das médias da análise de variância, e foi calculado o valor da diferença mínima significativa (DMS) 
e comparada com a diferença entre as médias das amostras, que devem ser menores, em módulo, que o valor da diferença mínima significativa (DMS). As amostras com diferença entre suas médias maior, em módulo, que o valor da diferença mínima significativa (DMS) são consideradas diferentes ${ }^{(65,76,77,78)}$. Os valores calculados das variâncias, das médias e da diferença mínima significativa (DMS) para cada um dos corpos de prova dissimilares estão apresentados nas tabelas 6.4 e 6.5 .

Tabela 6.4: Cálculo da variância das medições de dureza a $8 \mathrm{~mm}$ da linha de fusão.

\begin{tabular}{|c|c|c|c|c|c|c|}
\hline Microdureza a 8 mm & CP3 & CP4 & CP5 & CP6 & CP7 & CP8 \\
\hline $\mathbf{x 1}$ & 224,0 & 265,0 & 292,0 & 284,0 & 295,0 & 284,0 \\
\hline $\mathbf{x 2}$ & 322,0 & 292,0 & 337,0 & 312,0 & 317,0 & 292,0 \\
\hline $\mathbf{x 3}$ & 249,0 & 270,0 & 321,0 & 321,0 & 295,0 & 284,0 \\
\hline $\mathbf{x 4}$ & 240,0 & 292,0 & 320,0 & 303,0 & 298,0 & 299,0 \\
\hline $\mathbf{x 5}$ & 229,0 & 277,0 & 302,0 & 270,0 & 303,0 & 316,0 \\
\hline Soma & 1264,0 & 1396,0 & 1572,0 & 1490,0 & 1508,0 & 1475,0 \\
\hline Média & 226,5 & 271,0 & 297,0 & 277,0 & 299,0 & 300,0 \\
\hline Desvio & 39,9 & 12,4 & 17,6 & 20,8 & 9,2 & 13,3 \\
\hline Variância & 1590,7 & 154,7 & 310,3 & 432,5 & 84,8 & 177,0 \\
\hline Fonte da variação & $\mathbf{S Q}$ & $\mathbf{g l}$ & $\mathbf{M Q}$ & $\mathbf{F}$ & $\mathbf{v a l o r - P}$ & $\mathbf{F}$ crítico \\
\hline Entre grupos & 11596,2 & 5,0 & 2319,2 & 5,1 & 0,0 & 2,6 \\
\hline Dentro dos grupos & 11000,0 & 24,0 & 458,3 & & & \\
\hline \multicolumn{2}{|r|}{} & & & & & DMS \\
\hline Total & 22596,2 & 29,0 & & & & 41,839 \\
\hline
\end{tabular}

Realizada a verificação entre as médias de dureza da ferrita a $8 \mathrm{~mm}$ da linha de fusão das amostras dos corpos de prova dissimilares, onde a ruptura se deu na região do metal de base, nota-se que os valores de dureza da ferrita possuem variações menores e uma única variação maior em suas médias. Para esta região pode-se afirmar, com significância de $5 \%$, que todas as amostras são iguais com exceção do CP3 que é diferente de todas as demais. 
Tabela 6.5: Cálculo da variância das medições de dureza a $16 \mathrm{~mm}$ da linha de fusão.

\begin{tabular}{|c|c|c|c|c|c|c|}
\hline Microdureza a $16 \mathrm{~mm}$ & CP3 & CP4 & CP5 & CP6 & CP7 & CP8 \\
\hline $\mathbf{x 1}$ & 224,0 & 325,0 & 270,0 & 344,0 & 365,0 & 299,0 \\
\hline$\times 2$ & 322,0 & 365,0 & 330,0 & 332,0 & 344,0 & 277,0 \\
\hline$\times 3$ & 249,0 & 359,0 & 344,0 & 344,0 & 334,0 & 280,0 \\
\hline $\mathbf{x 4}$ & 240,0 & 316,0 & 344,0 & 312,0 & 326,0 & 299,0 \\
\hline$x 5$ & 229,0 & 334,0 & 308,0 & 325,0 & 354,0 & 284,0 \\
\hline Soma & 1264,0 & 1699,0 & 1596,0 & 1657,0 & 1723,0 & 1439,0 \\
\hline Média & 252,8 & 339,8 & 319,2 & 331,4 & 344,6 & 287,8 \\
\hline Desvio & 39,9 & 21,3 & 31,2 & 13,6 & 15,5 & 10,5 \\
\hline Variância & 1590,7 & 455,7 & 973,2 & 183,8 & 240,8 & 110,7 \\
\hline Fonte da variação & SQ & gl & $M Q$ & $\mathbf{F}$ & valor-P & F crítico \\
\hline Entre grupos & 31759,6 & 5,0 & 6351,9 & 10,7 & 0,0 & 2,6 \\
\hline \multirow[t]{2}{*}{ Dentro dos grupos } & 14219,6 & 24,0 & 592,5 & & & \\
\hline & & & & & & DMS \\
\hline Total & 45979,2 & 29,0 & & & & 47,570 \\
\hline
\end{tabular}

Realizada a verificação entre as médias de dureza da ferrita a $16 \mathrm{~mm}$ da linha de fusão das amostras dos corpos de prova dissimilares, onde a ruptura se deu na região do metal de base, nota-se que os valores de dureza da ferrita possuem variações maiores e também menores em suas médias. Para esta região pode-se afirmar, com significância de 5\%, que o CP3 é diferente do CP4, CP5, CP6 e CP7, que o CP7 é diferente do CP8 e que as demais amostras são todas iguais.

Os aços inoxidáveis superduplex possuem ferrita em sua matriz e o rápido aquecimento e resfriamento também podem ter causado sua fragilização, além disso, conforme descrito no item 3.3 a exposição a temperaturas superiores a $250{ }^{\circ} \mathrm{C}$ favorece a formação de fases deletérias, fragilizando este tipo de material. Porém o tempo de exposição foi curto, e como descrito no trabalho de Brandi ${ }^{(1)}$, para que esse tipo de fragilização aconteça a exposição deve ser prolongada, e diante destes fatos, optou-se por realizar a análise das fraturas em microscópio eletrônico de varredura com o intuito de identificar os tipos de fratura, figuras 6.5 a 6.10 . 


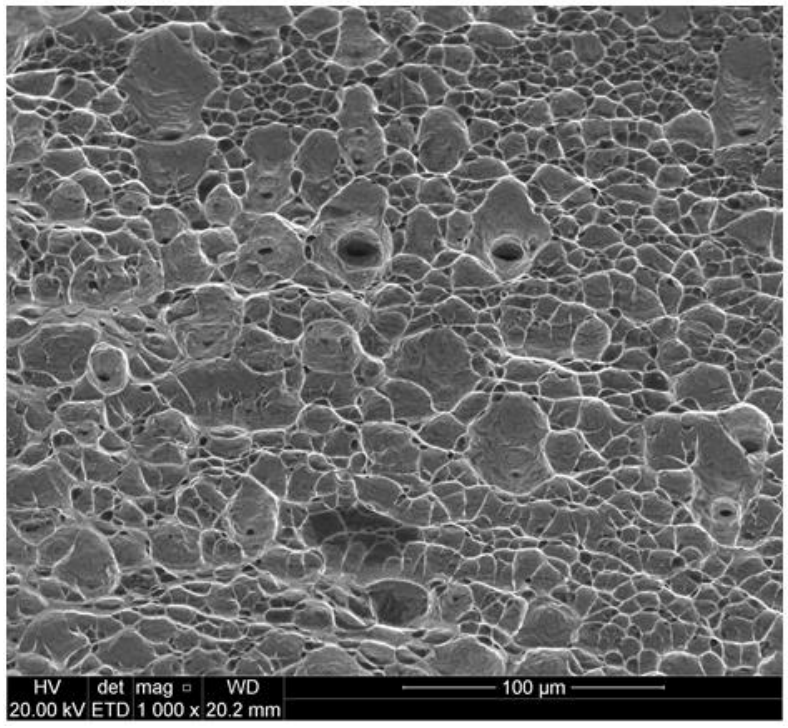

(a)

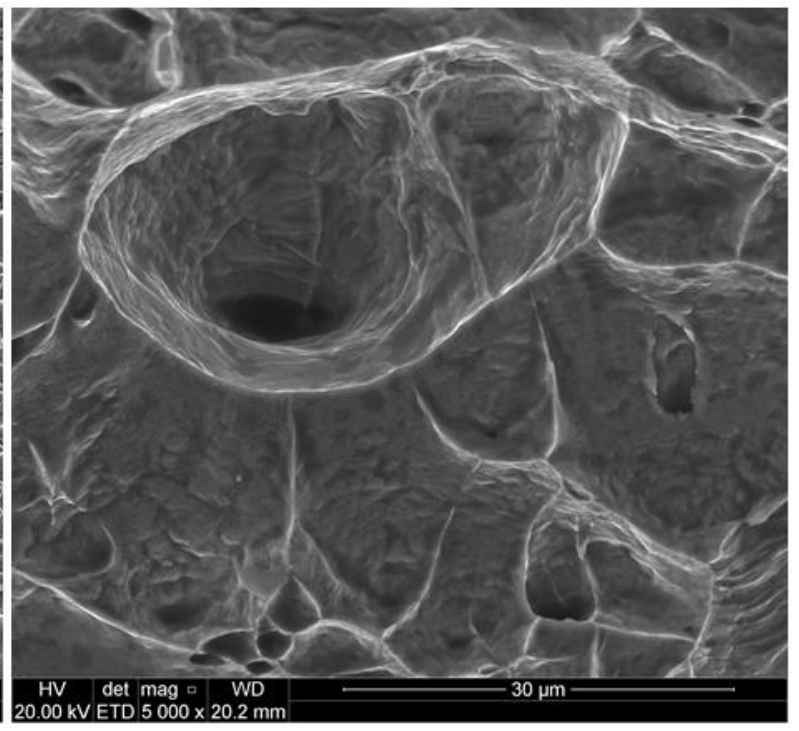

(b)

Figura 6.5 Imagem da superfície fratura do CP3 $(A+B+C A)$, com ampliação de $1.000 \times$ (a) e de 5.000 $X$ (b), após o ensaio de tração, predominância de alvéolos equiaxiais e alvéolos alongados.

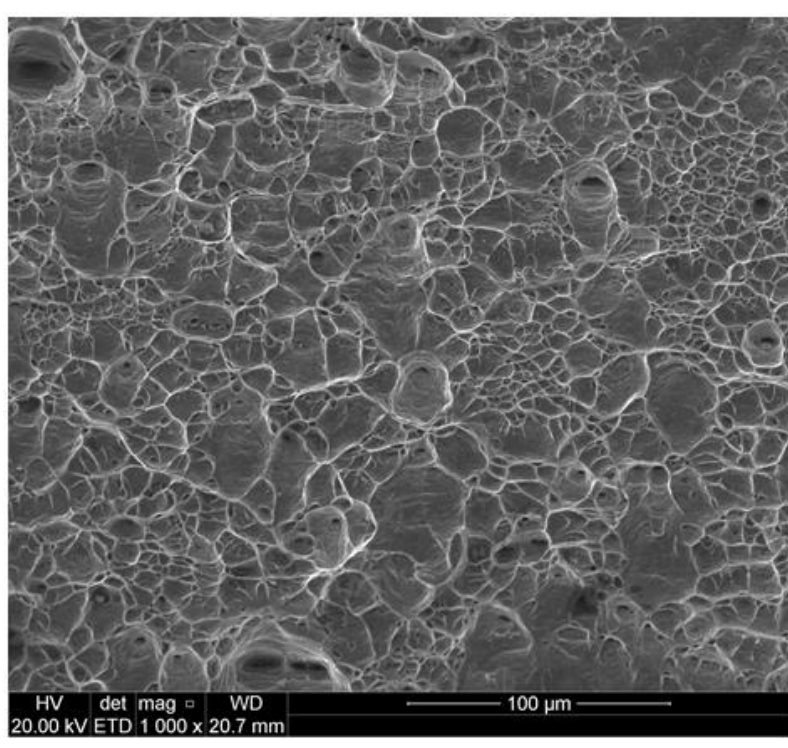

(a)

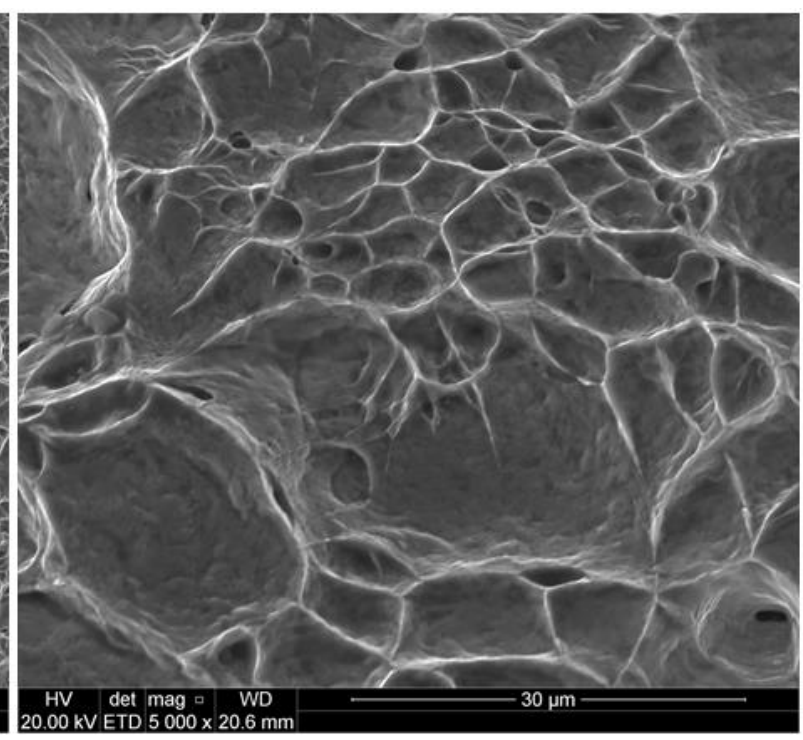

(b)

Figura 6.6 Imagem da superfície fratura do CP4 (A+B+CB), com ampliação de $1.000 \times$ (a) e de 5.000 $X$ (b), após o ensaio de tração, predominância de alvéolos equiaxiais e alvéolos alongados. 


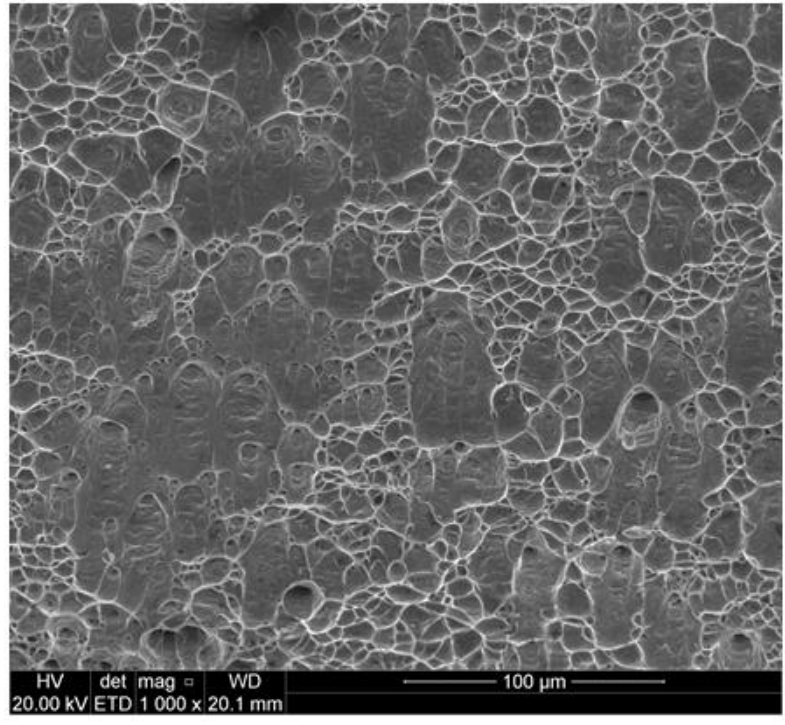

(a)

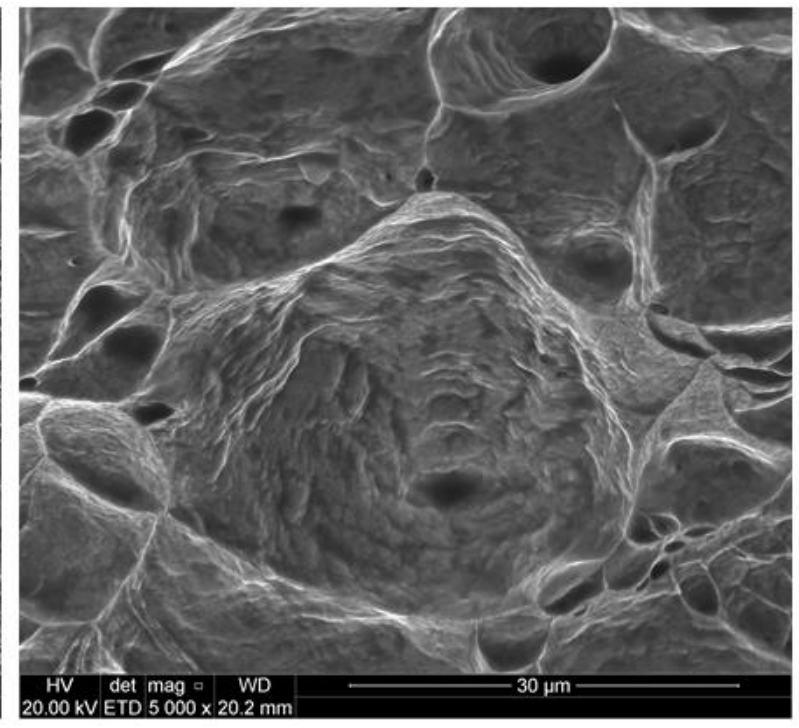

(b)

Figura 6.7 Imagem da superfície fratura do CP5 (A+B+CA), com ampliação de $1.000 \times$ (a) e de 5.000 $X(b)$, após o ensaio de tração, predominância de alvéolos equiaxiais e alvéolos alongados.

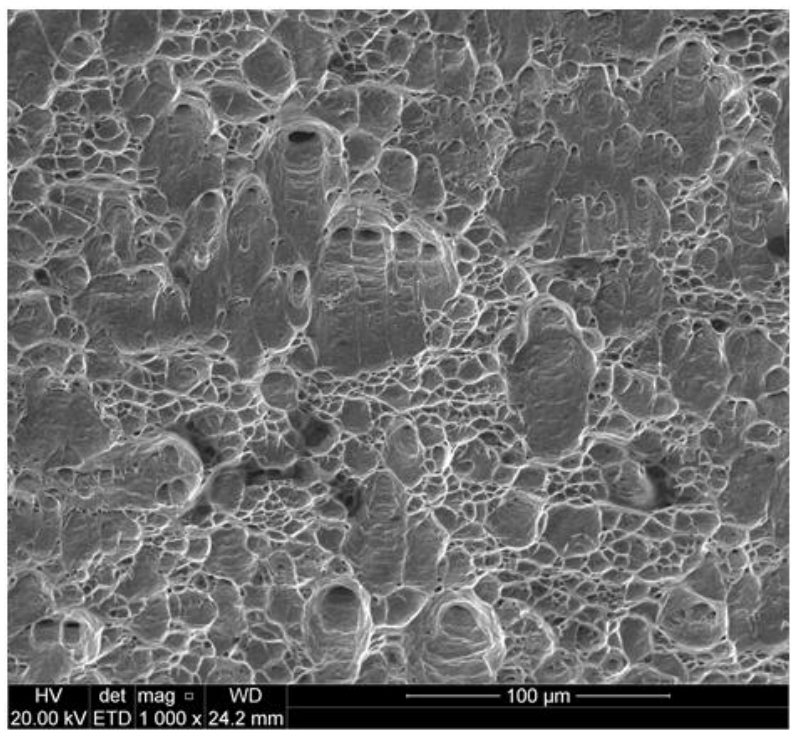

(a)

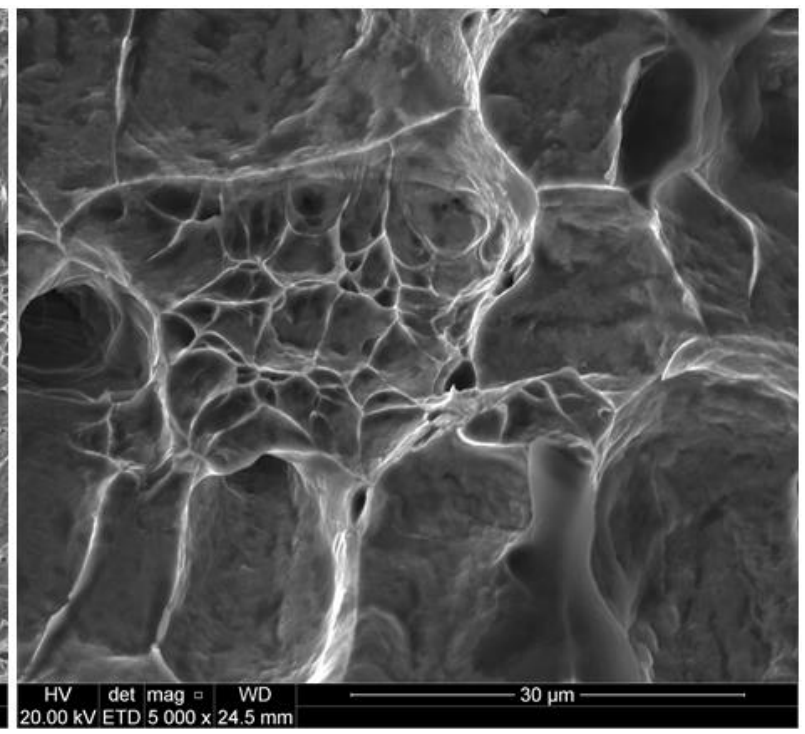

(b)

Figura 6.8 Imagem da superfície fratura do CP6 $(A+B+C B)$, com ampliação de $1.000 \times(a)$ e de 5.000 $X(b)$, após o ensaio de tração, predominância de alvéolos equiaxiais e alvéolos alongados. 


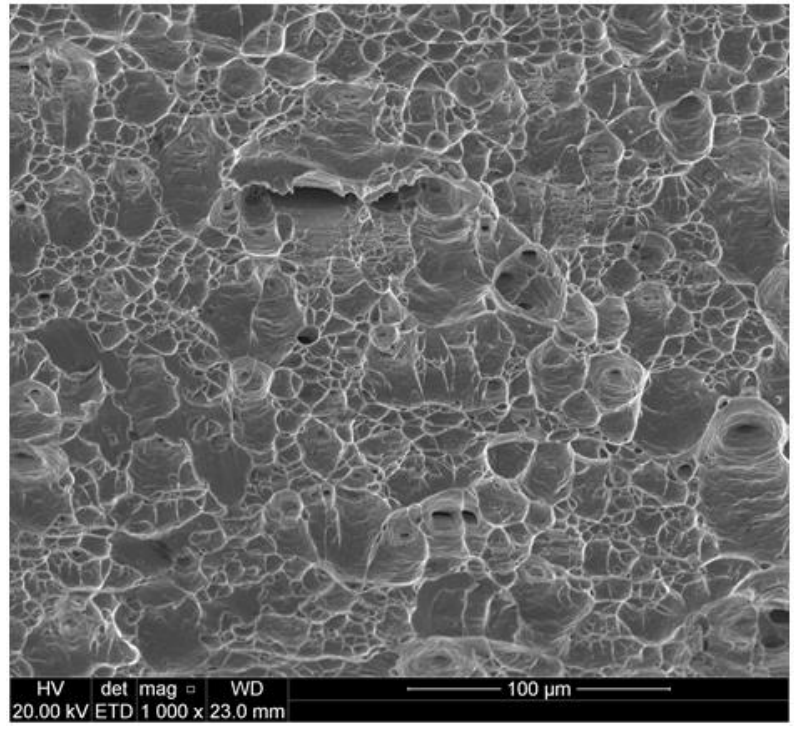

(a)

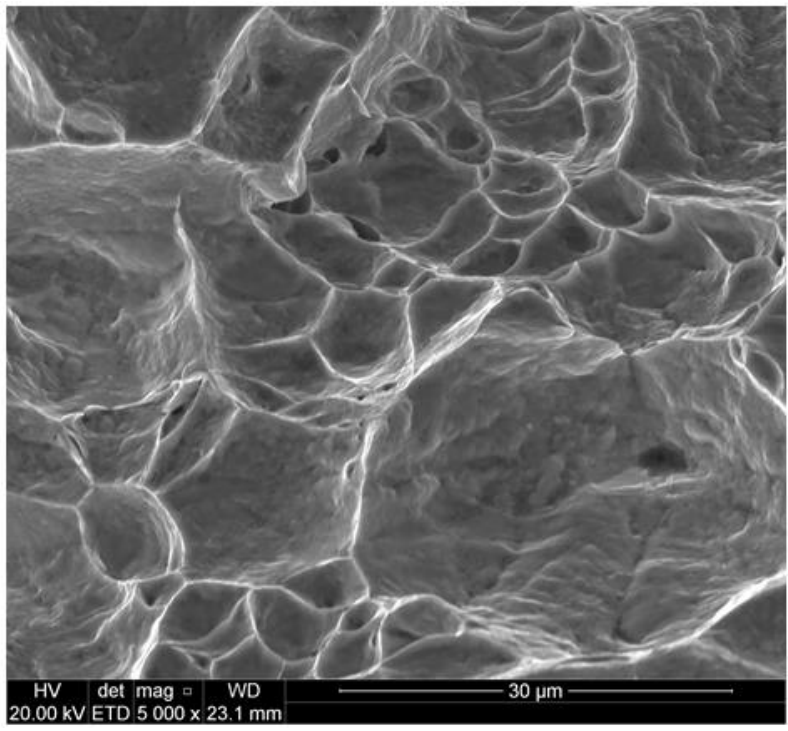

(b)

Figura 6.9 Imagem da superfície fratura do CP7 $(A+B+C A)$, com ampliação de $1.000 \times$ (a) e de 5.000 $X$ (b), após o ensaio de tração, predominância de alvéolos equiaxiais e alvéolos alongados.

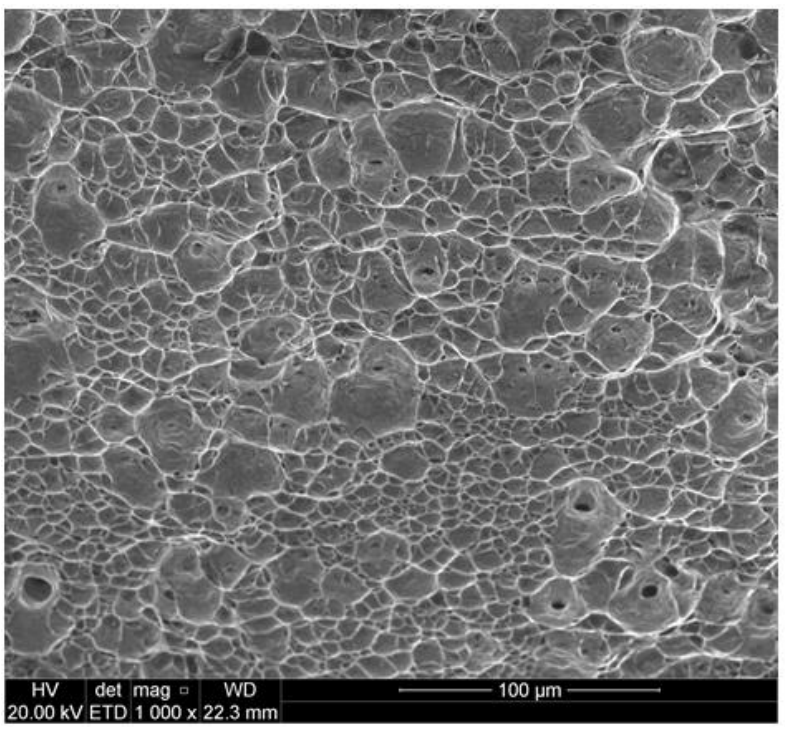

(a)

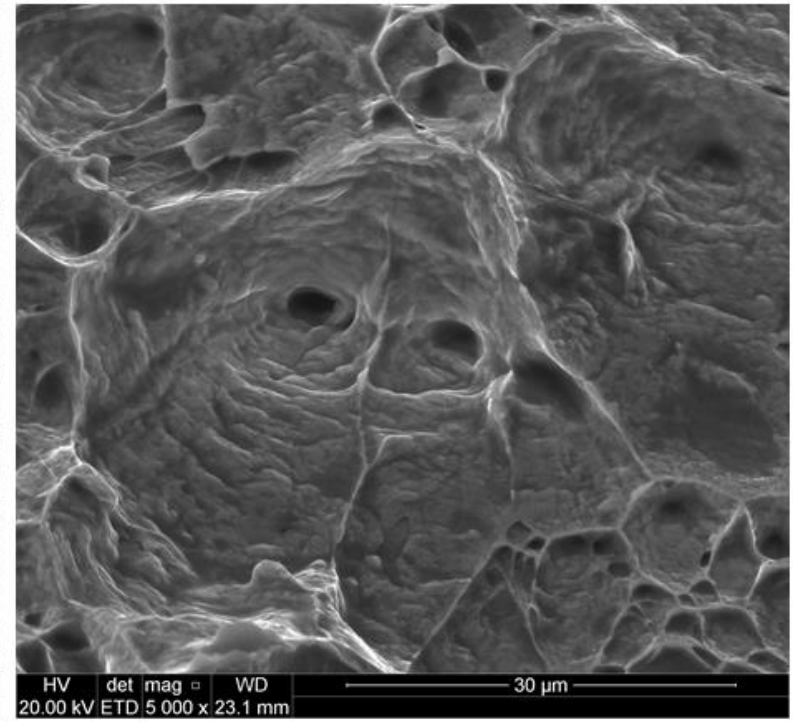

(b)

Figura 6.10 Imagem da superfície fratura do CP8 ( $A+B+C B)$, com ampliação de $1.000 \mathrm{X}$ (a) e de $5.000 \times$ (b), após o ensaio de tração, predominância de alvéolos equiaxiais e alvéolos alongados.

De acordo com Silva ${ }^{(75)}$, em geral a fratura frágil é perpendicular ao sentido da tensão de tração, característico de metais com elevada dureza que apresentam pouco ou nenhum escorregamento de suas discordâncias. Ao analisar as fractografias de todos os corpos de prova dissimilares percebe-se a presença de alvéolos, também conhecidos por dimples, característicos de rupturas contínuas, lentas e graduais do material, típico do mecanismo de fratura dúctil e neste caso 
todas as fraturas estão tomadas por alvéolos equiaxiais e alongados, indicando que as fraturas de todos os corpos de prova dissimilares se deu maneira dúctil. Mesmo assim, a hipótese de fragilização a $475^{\circ} \mathrm{C}$ não está totalmente descartada, visto que este material possui uma matriz ferrítica/austenítica e a ruptura da austenita se dá de maneira dúctil, ainda segundo Brandi ${ }^{(1)}$, é possível que a fragilização a $475{ }^{\circ} \mathrm{C}$ possa ter iniciado.

\subsubsection{ENSAIO DE DOBRAMENTO}

Verificou-se que as dimensões dos poucos poros encontrados após o ensaio de dobramento atendem aos requisitos da norma na qual este ensaio foi baseado, ASME IX QW-163 ed. 2013, e uma vez que nenhuma abertura ultrapassou o limite máximo de 3,2 mm, em qualquer direção, pode-se afirmar que a soldagem dissimilar não afetou o desempenho das amostras neste ensaio.

\subsection{ENSAIOS DE CORROSÃO}

\subsubsection{ENSAIO DE CORROSÃO - G48}

Segundo Brandi ${ }^{(1)}$ para os aços inoxidáveis superduplex a temperatura crítica de PIT, corrosão localizada puntiforme ou alveolar, para o metal de base é superior a $100{ }^{\circ} \mathrm{C}$ e para o metal de solda é de aproximadamente $70^{\circ} \mathrm{C}$, e como já era esperado, uma vez que o ensaio de corrosão foi realizado com temperatura de 40 ${ }^{\circ} \mathrm{C}$, e face a elevada resistência a corrosão localizada puntiforme e também a alta resistência à corrosão generalizada por cloretos destes aços, a perda de massa das amostras foi muito inferior a $0,0001 \mathrm{~g} / \mathrm{cm}^{2}$, que é o mínimo estabelecido pela norma que rege este ensaio, ASTM G-48, e portanto pode-se afirmar que a soldagem dissimilar não afetou a resistência a corrosão deste aços segundo os critérios desta norma. 


\subsubsection{TÉCNICA LOCALIZADA DE SVET}

Apesar desta técnica não fazer parte do escopo inicial deste trabalho, foi realizada apenas em caráter qualitativo, e como complementação ao ensaio G-48, porém foi possível identificar, pela representação de forma gráfica, as reações de corrosão que ocorreram em algumas regiões das amostras, neste ensaio a solução utilizada de $3,5 \% \mathrm{NaCl}$ em massa acidificada com $\mathrm{HCl}$ e com $\mathrm{pH}=2$ é mais corrosiva do que a solução de cloreto férrico hexa-hidratado $\left(\mathrm{FeCl}_{3} \cdot 6 \mathrm{H}_{2} \mathrm{O}\right)$ de $\mathrm{pH}=3$ utilizada no ensaio da G-48. Conhecendo-se as características dos materiais testados é possível fazer uma correlação com o fluxo dos elétrons, densidade das correntes iônicas, e o desgaste causado pelo processo de corrosão, perda de material.

Ao analisar os resultados dos ensaios da amostra $\mathrm{CP} 1(\mathrm{~A}+\mathrm{A}+\mathrm{CA})$, após $2 \mathrm{~h}$ de ensaio, figura 6.10 , pode-se perceber pelos picos e vales logo no início do processo de corrosão na região do metal de solda. Após 6 h de ensaio, figura 6.11, o processo de corrosão atinge uma área maior na região do metal de solda, percebe-se o aumento na quantidade de picos no metal de solda e após $20 \mathrm{~h}$ de ensaio, figura 6.12, aparentemente o processo de corrosão estabilizou, pode-se perceber que a quantidade de picos no metal de solda diminuiu.

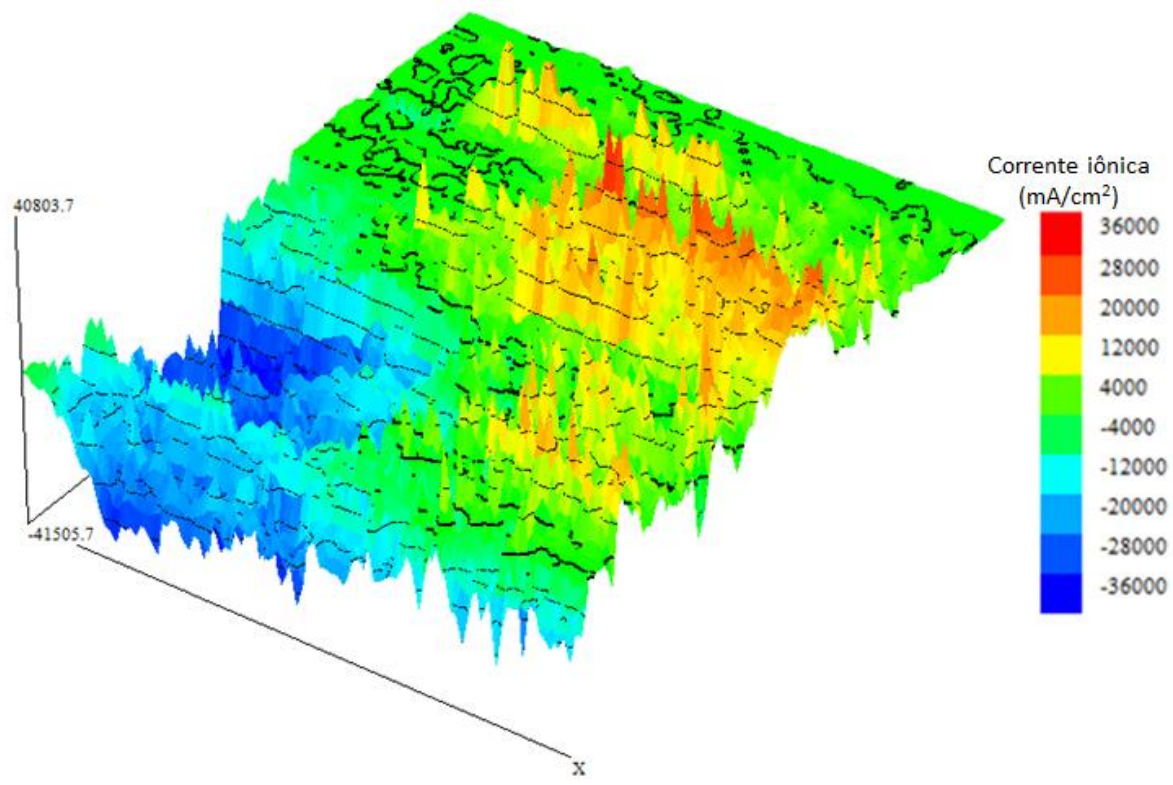

Figura 6.11: Imagem em 3D das densidades das correntes iônicas no CP1 $(A+A+C A)$, após 2h de ensaio. 


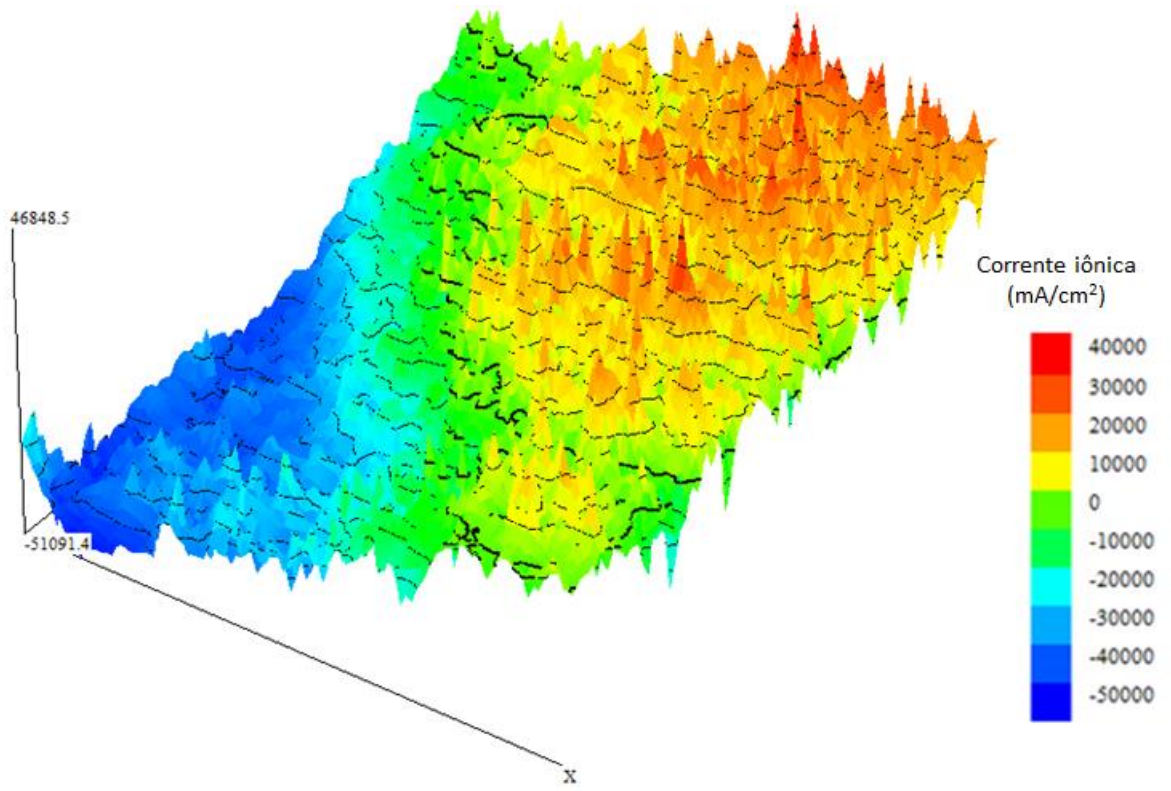

Figura 6.12: Imagem em 3D das densidades das correntes iônicas no CP1 $(A+A+C A)$, após 6h de ensaio.

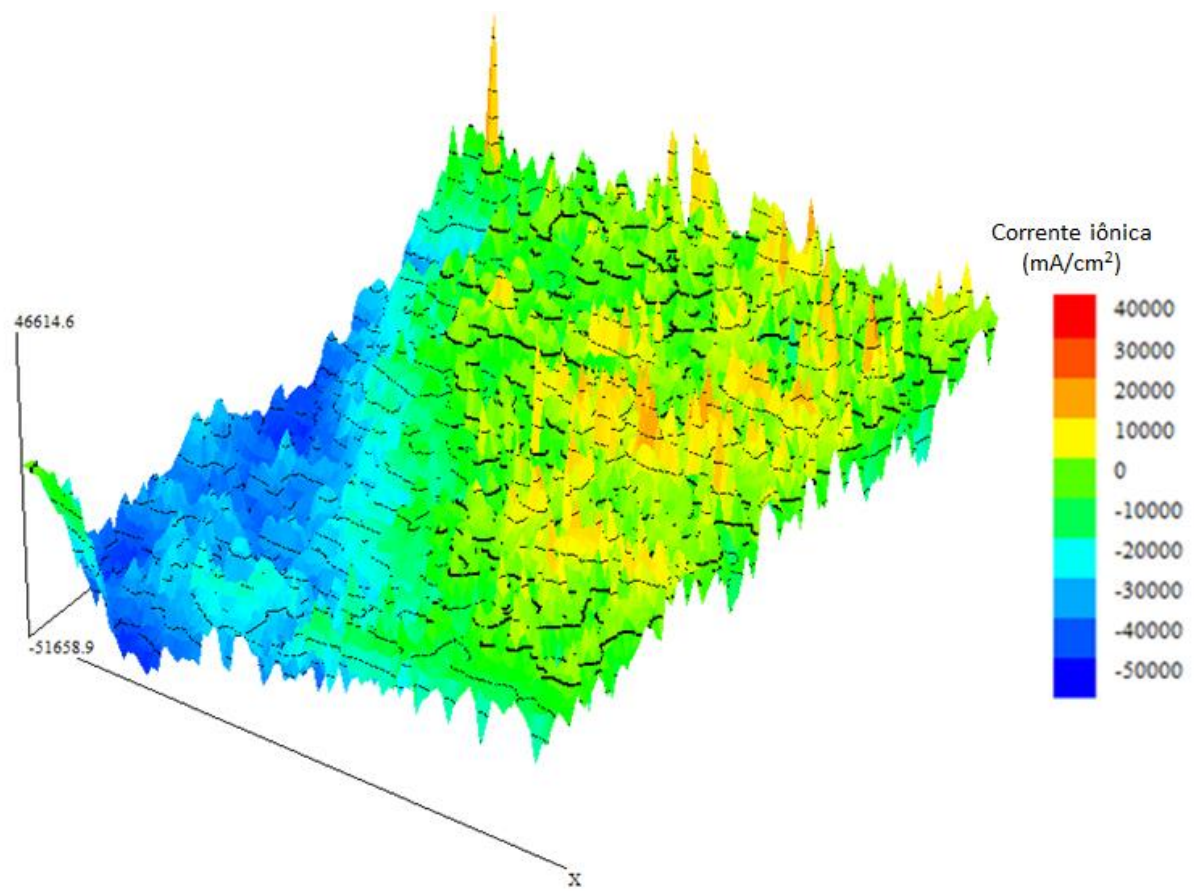

Figura 6.13: Imagem em 3D das densidades das correntes iônicas no $C P 1(A+A+C A)$, após 20h de ensaio.

Ao analisar os resultados dos ensaios da amostra CP2 (B+B+CB), após $2 \mathrm{~h}$ de ensaio, figura 6.13 , pode-se perceber o início do processo de corrosão em alguns pontos do metal de solda, apesar da cor alaranjada em toda a amostra o valor apresentado na escala é zero, com poucos e pequenos picos na região do metal de solda. Após $6 \mathrm{~h}$ de ensaio, figura 6.14, notadamente houve, apesar da baixa 
intensidade, aumento do processo de corrosão no metal de solda, que apresenta um pico maior, porém não tão acentuado e após $20 \mathrm{~h}$ de ensaio, figura 6.15 , apesar das várias mudanças de coloração na região do metal de base ao longo do tempo, os valores nas escalas se mantiveram constantes em zero indicando que não houve corrosão nesta região e apresenta um único pico com aumento de intensidade.

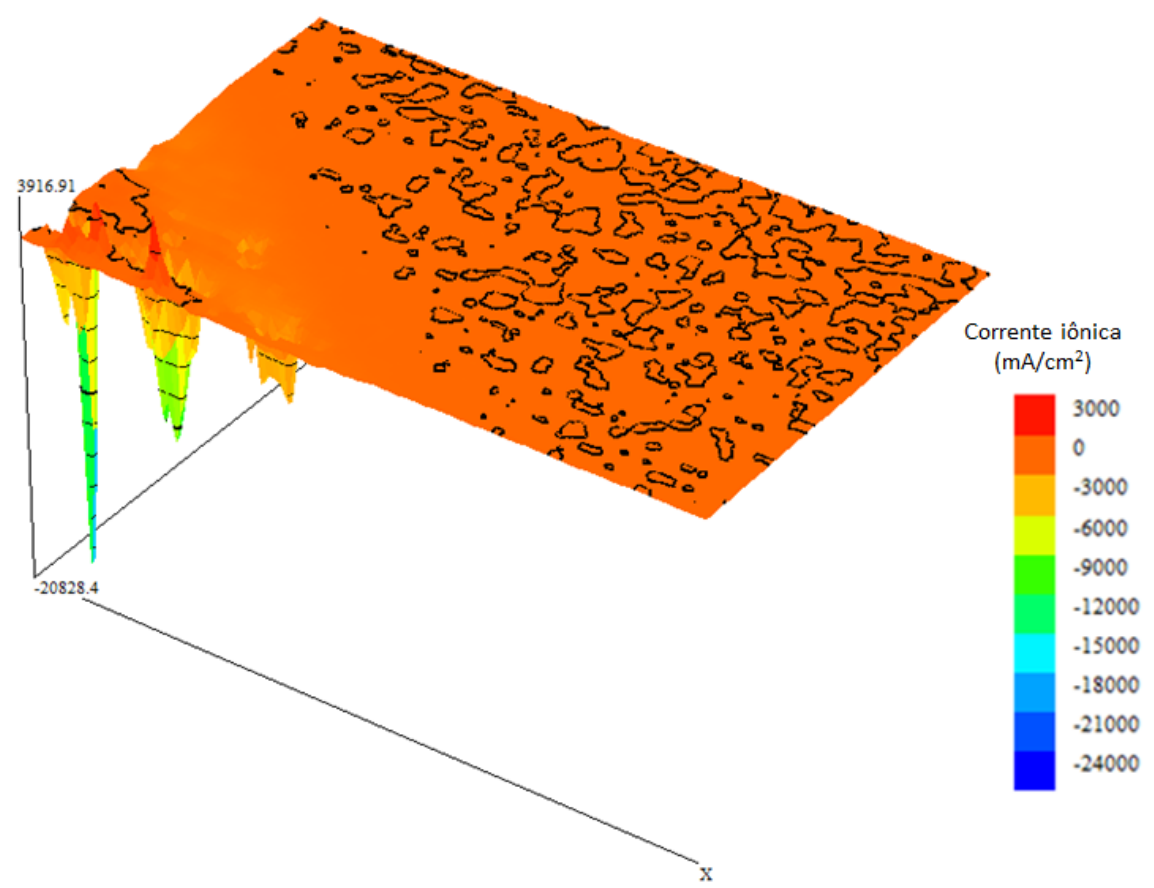

Figura 6.14: Imagem em 3D das densidades das correntes iônicas no CP2 $(B+B+C B)$ após 2h de ensaio.

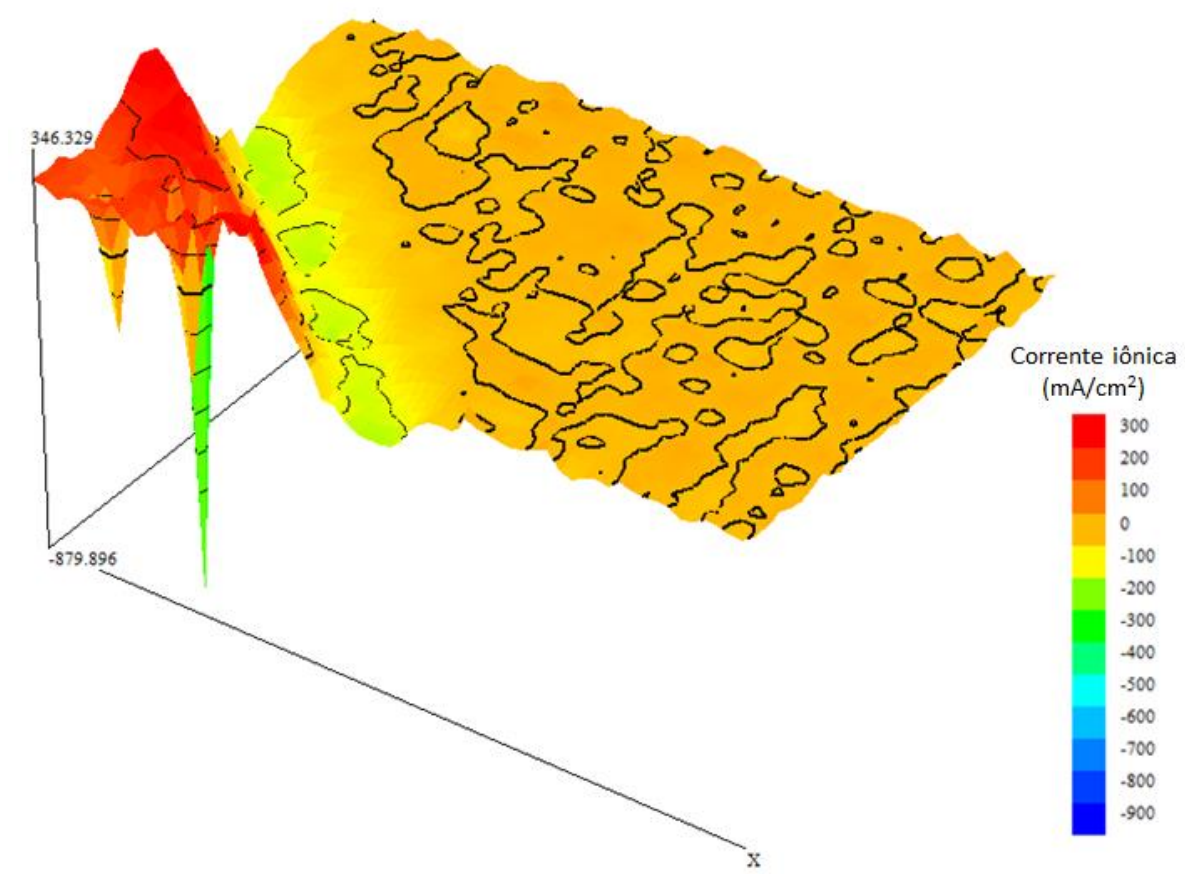

Figura 6.15: Imagem em 3D das densidades das correntes iônicas no CP2 (B+B+CB) após 6h de ensaio. 


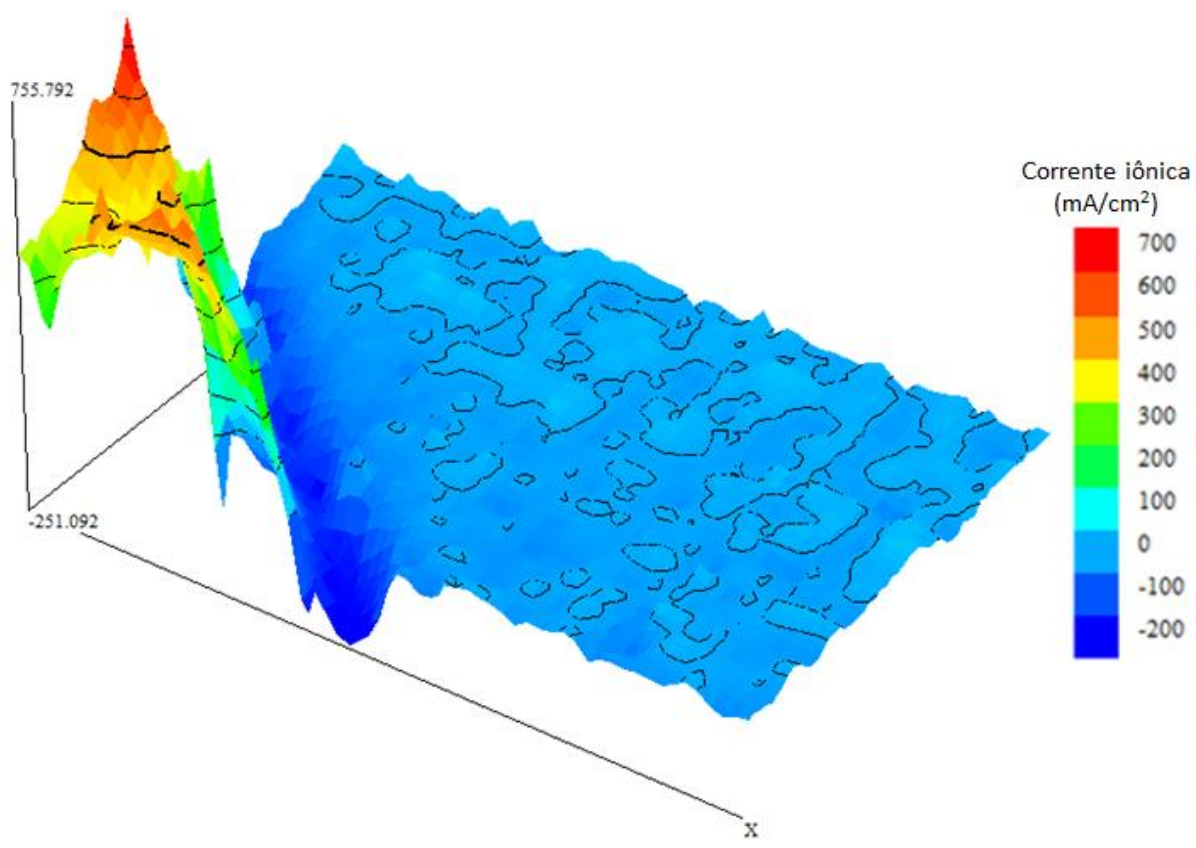

Figura 6.16: Imagem em 3D das densidades das correntes iônicas no CP2 (B+B+CB) após 20h de ensaio.

Ao analisar os resultados dos ensaios da amostra CP5 $(A+B+C A)$, após $2 h$ de ensaio, figura 6.16 , tem inicio um processo de corrosão generalizado em toda a amostra e nota-se um pico na região do metal de base. Após 6h de ensaio, figura 6.17, cessa a corrosão generalizada em toda a amostra e percebe-se a corrosão puntiforme em algumas regiões do metal de solda, pode-se ver uns poucos picos com intensidades elevadas e após $20 \mathrm{~h}$ de ensaio, figura 6.18 , a condição da região do metal de base se manteve constante sem corrosão e nota-se diminuição de atividade na região do metal de solda apresar do aumento de intensidade em um único ponto. 




Figura 6.17: Imagem em 3D das densidades das correntes iônicas no CP5 $(A+B+C A)$ após $2 h$ de ensaio.

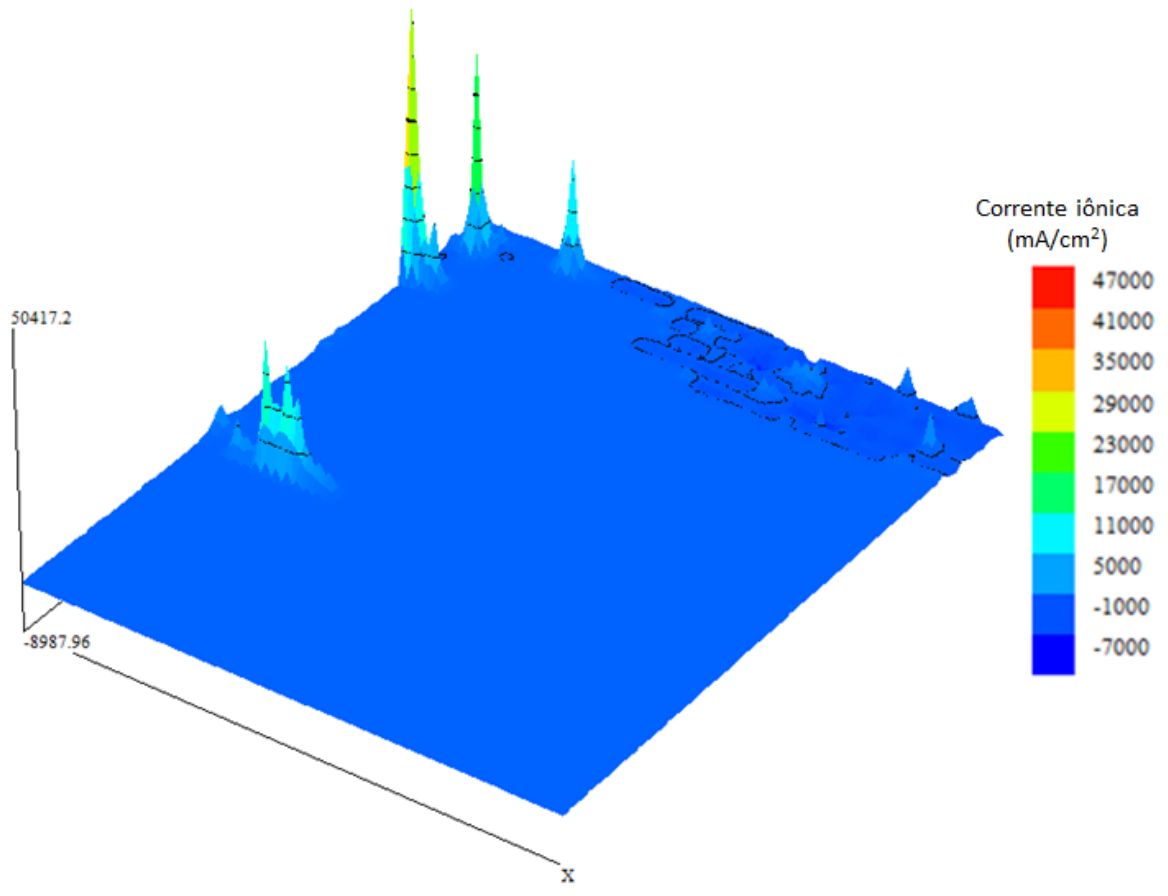

Figura 6.18: Imagem em 3D das densidades das correntes iônicas no CP5 $(A+B+C A)$ após 6 h de ensaio. 


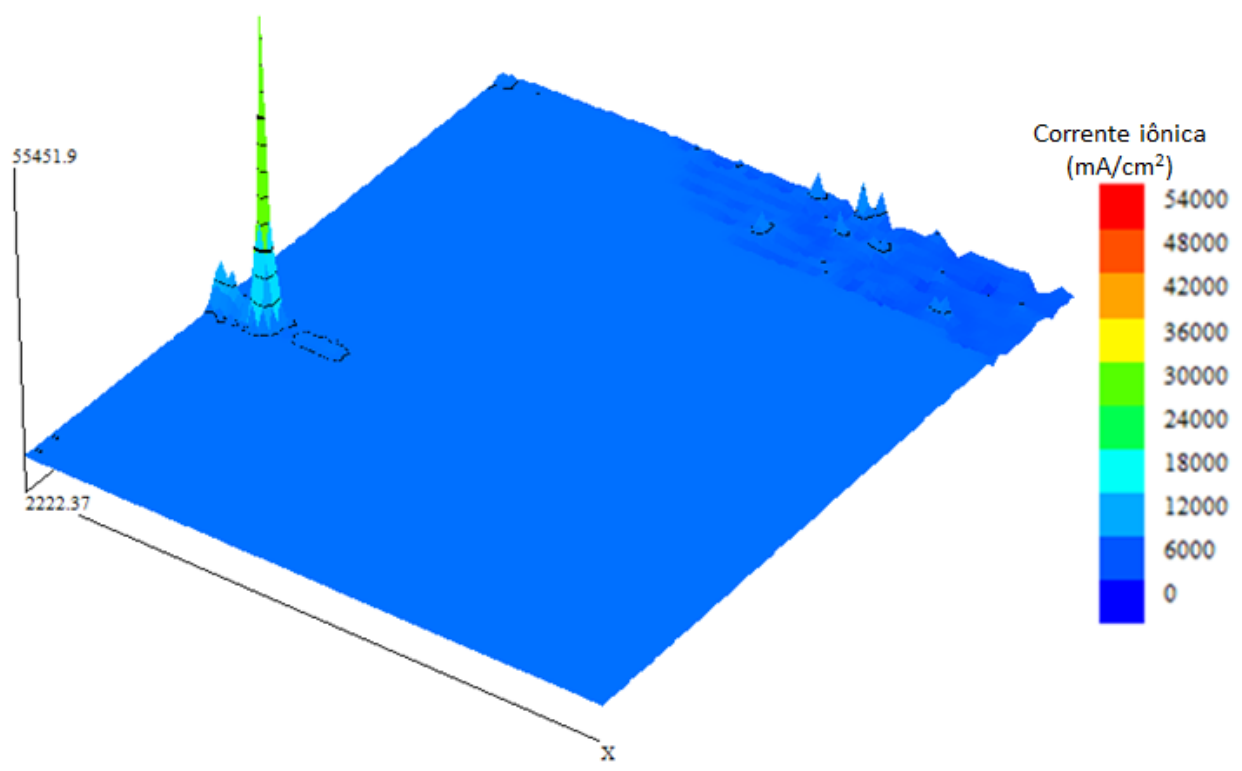

Figura 6.19: Imagem em 3D das densidades das correntes iônicas no CP5 $(A+B+C A)$ após 20h de ensaio.

Ao analisar os resultados dos ensaios da amostra CP6 $(A+B+C B)$, após $2 \mathrm{~h}$ de ensaio, figura 6.19, não há indícios de corrosão, apesar da coloração vermelha as correntes iônicas são negativas, percebe-se a atividade não corrosiva com vales na região da ZAC. Após 6h de ensaio, figura 6.20, não há nenhuma atividade nas regiões do metal base e do metal de solda e o valor apresentado na escala é zero, e após $20 \mathrm{~h}$ de ensaio, figura 6.21 , nota-se o processo de corrosão tanto na região do metal de solda quanto no metal base e a intensidade das correntes iônicas alcança $20.000 \mathrm{~mA} / \mathrm{cm} 2$, a atividade não corrosiva com vales na região da ZAC continua. 


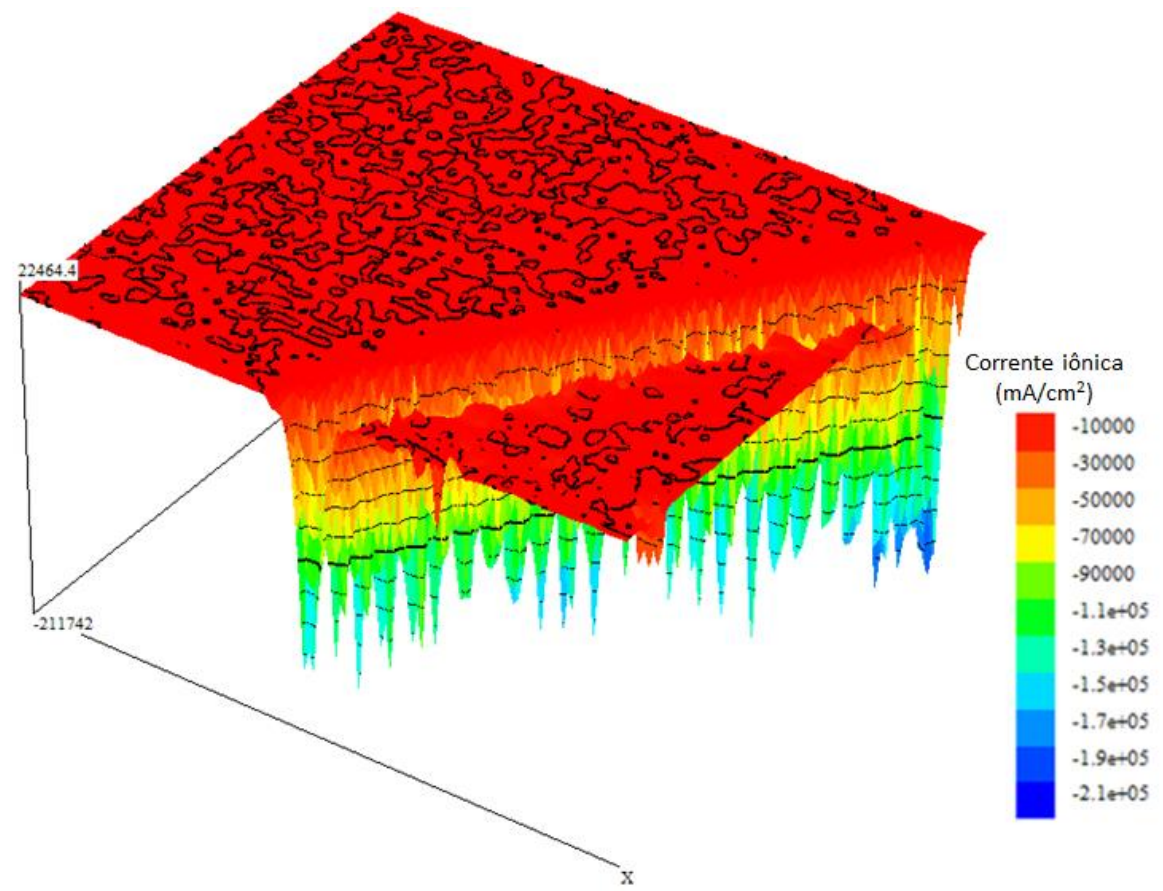

Figura 6.20: Imagem em 3D das densidades das correntes iônicas no CP6 ( $A+B+C B)$ após $2 h$ de ensaio.

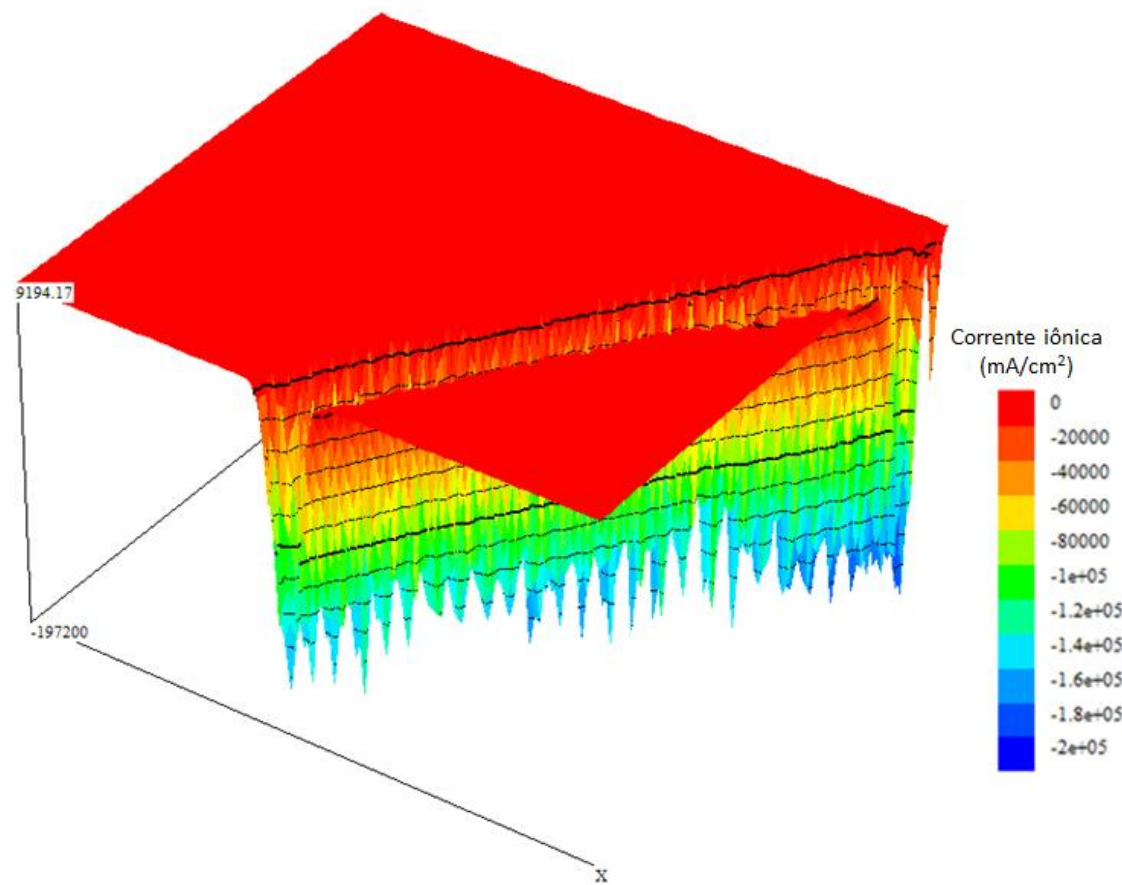

Figura 6.21: Imagem em 3D das densidades das correntes iônicas no CP6 $(A+B+C B)$ após 6h de ensaio. 


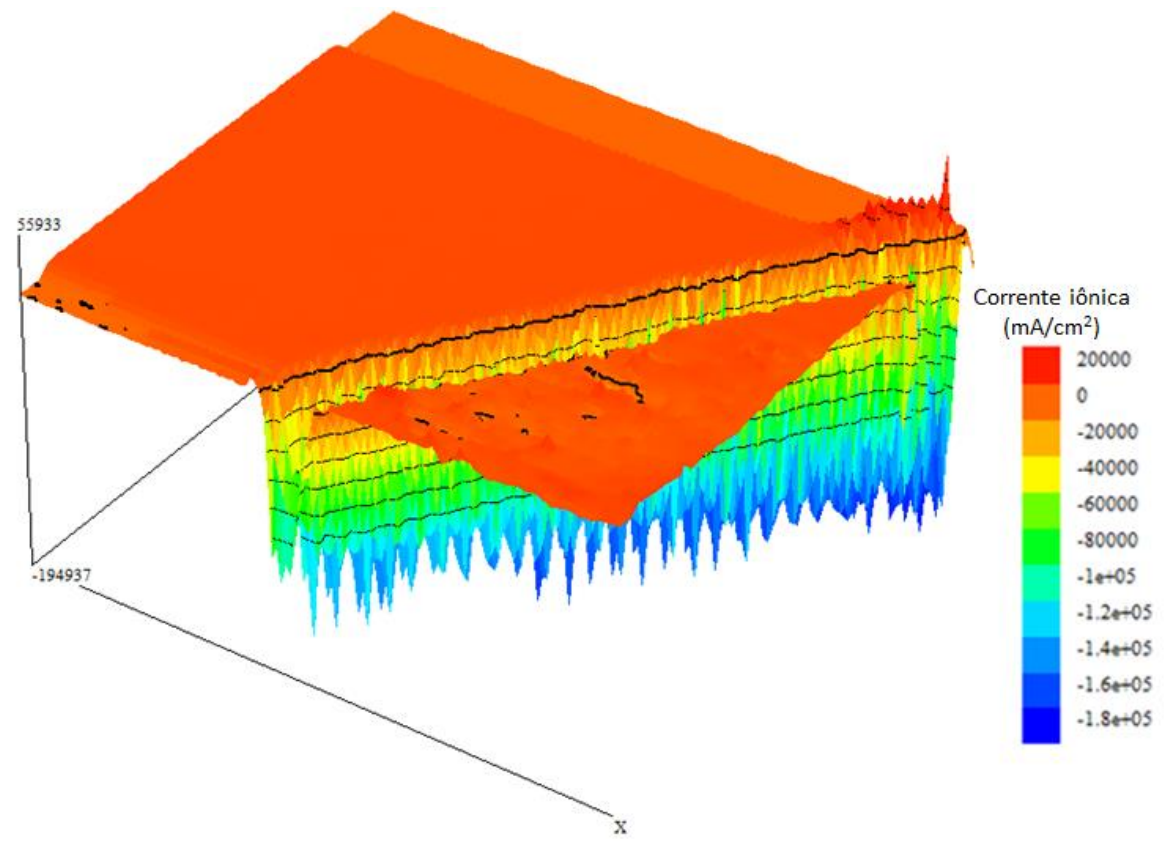

Figura 6.22: Imagem em 3D das densidades das correntes iônicas no CP6 ( $A+B+C B)$ após 20h de ensaio.

$\mathrm{Na}$ amostra $\mathrm{CP} 1(\mathrm{~A}+\mathrm{A}+\mathrm{CA})$, figuras $6.10,6.11$ e 6.12 , o processo de corrosão inicia tem um aumento e em seguida há diminuição da corrosão. $\mathrm{Na}$ amostra CP2 $(B+B+C B)$, figuras $6.13,6.14$ e 6.15 , o processo de corrosão se inicia em alguns pontos do metal de solda, há uma diminuição da intensidade e em seguida os valores nas escalas se mantiveram constantes em zero indicando que não houve corrosão generalizada nesta região, apenas um único ponto de corrosão localizada puntiforme. Na amostra CP5 $(A+B+C A)$, figuras $6.16,6.17$ e 6.18 , têm inicio $u / m$ processo de corrosão generalizado em toda a amostra com um pico na região do metal de base, e em seguida cessa a corrosão generalizada em toda a amostra apenas com algumas regiões do metal de solda, aumento de intensidade em um único ponto. $\mathrm{Na}$ amostra $\mathrm{CP} 6(\mathrm{~A}+\mathrm{B}+\mathrm{CB})$, figuras $6.19,6.20$ e 6.21, no início não há indícios de corrosão, em seguida começa uma atividade não corrosiva, e logo após têm início um processo de corrosão tanto na região do metal de solda quanto no metal base e a intensidade das correntes iônicas alcança 20.000 mA/cm2. 
Após analisar os dados deste ensaio fica evidente que a solução utilizada consumiu os nitretos, a escória e também a austenita secundária presente na superfície dos metais de solda e em seguida forma-se a camada apassivadora de óxido de cromo $\left(\mathrm{Cr}_{2} \mathrm{O}_{3}\right)$ sobre a superfície da amostra, camada que é impermeável e insolúvel em meios menos agressivos, e diminui a atividade de corrosão nas amostras. As amostras dos corpos de prova dissimilares, CP5 $(A+B+C A)$ e CP6 $(A+B+C B)$, notadamente tiveram um desempenho melhor que as amostras dos corpos de prova similares $C P 1(A+A+C A)$ e $C P 2(B+B+C B)$, pode-se afirmar que a soldagem dissimilar não afetou o desempenho de resistência a corrosão, comparativamente com as amostras similares, logo a luz deste ensaio a soldagem dissimilar é perfeitamente factível. 


\section{CONCLUSÕES}

Com base nos materiais e métodos utilizados neste trabalho e após a análise de todos os resultados dos ensaios realizados nas amostras, e seguindo as diretrizes da norma na qual este estudo foi baseado, Norsok M-601, conclui-se que os aços inoxidáveis superduplex podem ser utilizados conjuntamente em um mesmo sistema de tubulações industriais e com a utilização do processo de soldagem com arame tubular (MCAW).

Vale apena salientar que a norma Norsok M-601, utilizada como referência para este trabalho, não aborda a identificação de fases deletérias com uso de técnicas diferentes das utilizadas neste trabalho. Face ao grande potencial de fragilização destes aços causado pela presença de fases deletérias, esta norma não deveria deixa de fora de seu conteúdo ensaios importantes como o EBSD e o DRX, que permitem identificar a presença de fases intermetálicas, mesmo em pequenas quantidades. 


\section{SUGESTÕES DE TRABALHOS FUTUROS}

1. Repetir a soldagem dos aços inoxidáveis superduplex UNS S32750 e UNS S32760 com energias de soldagem fora dos limites normativos e avaliar os efeitos.

2. Repetir a soldagem dos aços inoxidáveis superduplex UNS $\$ 32750$ e UNS S32760 utilizando chapas com maior espessura e com energias de soldagem diferentes.

3. Repetir a soldagem dos aços inoxidáveis superduplex UNS S32750 e UNS S32760 utilizando os demais processos de soldagem comentados neste trabalho.

4. Aprofundar a análise das fases secundárias após a soldagem dos aços inoxidáveis superduplex UNS S32750 e UNS S32760 utilizando os ensaios EBSD e DRX.

5. Determinar o limite das fases secundárias dos aços inoxidáveis superduplex UNS S32750 e UNS S32760 após a soldagem sem que afetem a resistência mecânica e de corrosão. 


\section{REFERÊNCIAS BIBLIOGRÁFICAS}

${ }^{1}$ Brandi, S. D., Estudo da soldabilidade do aço inoxidável duplex DIN W. Nr. 1.4462 (UNS S31803), tese de doutorado, EPUSP, 1992.

${ }^{2}$ Brandi, S. D.; Lippold J. C., Considerações sobre a metalurgia da soldagem de aços inoxidáveis duplex e superduplex, Metalurgia \& Materiais, p. 141 - 146, 1997.

${ }^{3}$ Brandi, S. D.; Wainer, E.; Mello F. D. H., Soldagem - Processos e metalurgia, primeira edição 1992.

${ }^{4}$ Ramírez, A. J., Estudo da precipitação de nitreto de cromo e fase sigma por simulação térmica da zona afetada pelo calor na soldagem multipasse de aços inoxidáveis duplex, dissertação de mestrado, EPUSP, 1997.

${ }^{5}$ Ramírez, A. J., Precipitação de fases intermetálicas e austenita secundária na ZAC de soldagem multipasse de aços inoxidáveis duplex, tese de doutorado, EPUSP, 2001.

${ }^{6}$ Giraldo, C. P. S., Precipitação de fases intermetálicas na zona afetada pelo calor de baixa temperatura (ZACBT) na soldagem multipasse de aços inoxidáveis duplex, dissertação de mestrado, EPUSP, 2001.

${ }^{7}$ Nilsson, J.O., Superduplex Stainless Steels, Materials Science and Technology, v.8, n.8, p. 685-700, 1992.

${ }^{8}$ Charles, J.; Bernhardsson, S., Superduplex Stainless Steels: structure and properties. In: CONFERENCE DUPLEX STAINLESS STEELS'91. Anais... Beaune Bourcogne France, p. 3-48, 1991.

${ }^{9}$ Armas, I.A., Moreuil, S.D., Duplex Stainless Steels, Primeira edição 2009. 
${ }^{10}$ Callister Jr., W.D., Introdução à ciência e engenharia de materiais, Sétima edição 2007.

${ }^{11}$ Grong, O., Metallurgical Modelling of Welding, segunda edição 1997.

${ }^{12}$ Linnert, G.E., Welding metallurgy, quarta edição, 1994.

${ }^{13}$ American Welding Society, Specification for bare stainless steel welding electrodes and rods, 2006.

${ }^{14}$ Weiss, N.R., Soldagem de aços inoxidáveis duplex, Universidade Petrobras, 2009.

${ }^{15}$ Meneses, M.S., Processos de soldagem, refinaria Henrique Lages - Petrobras, 2008.

${ }^{16}$ Sandivik Materials Technology, Stainless welding products. catálogo de materiais Sandivik, 2006.

${ }^{17}$ Fager, S.A., Odegard, L., Ekstrom, U., UNS S32750 (SAF 2507) Welding procedures and properties of welding joints, Welding reporter, catálogo de materiais Sandivik, 1992.

${ }^{18}$ Sandivik Materials Technology, Welding Guidelines for SAF 2507 (UNS S32750), catálogo de materiais Sandivik, 2009.

${ }^{19}$ Sandivik Materials Technology, Duplex Stainless Steels, catálogo de materiais Sandivik, 2009.

${ }^{20}$ Chai, G., Nystrom, M., Mechanical properties of Sandivik SAF 2205 and SAF 2507 (UNS S32750), catálogo de materiais Sandivik, 2004.

${ }^{21}$ Frikken, D., ASME B31.3 Introduction Course, Brecht Engineering Company, 2009.

${ }^{22}$ Nayyar, M.L., Piping Handbook, sétima edição 2000. 
${ }^{23}$ ASME B1.20.1, Pipe threads general purpose (inch), American Society of Mechanical Engineers, 2006.

${ }^{24}$ ASME B16.5, Pipe flanges and flanged fittings, American Society of Mechanical Engineers, 2003.

${ }^{25}$ Medeiros, R.C., Estudo da soldabilidade dos aços inoxidáveis duplex, Universidade Petrobras, 2009.

${ }^{26}$ AWS A3.0, Standard welding terms and definitions, American Welding Society, 2004.

${ }^{27} \mathrm{API} 1104$, Welding of pipelines and related facilities, American Petroleum Institute, 2005.

${ }^{28} \mathrm{M}-601$, Welding and inspection of piping, Norsok Standard, 2008.

${ }^{29}$ ASME B16.9, Factory - made wrought buttwelding fittings, American Society of Mechanical Engineers, 2003.

${ }^{30}$ ASME B16.11, Forged fittings, socket-welding and theaded, American Society of Mechanical Engineers, 2005.

${ }^{31}$ ASME B16.34, Valves - flanged, threaded, and welding end, American Society of Mechanical Engineers, 2004.

${ }^{32}$ ASME B31.3, Process piping, American Society of Mechanical Engineers, 2010.

${ }^{33}$ ASME B31.4, Pipeline transportation systems for liquid hydrocarbons and other liquids, American Society of Mechanical Engineers, 2006.

${ }^{34}$ ASME B31.8, Gas transmission and distribution piping systems, American Society of Mechanical Engineers, 2003. 
${ }^{35}$ ASME B36.10, Welded and seamless wrought steel pipe, American Society of Mechanical Engineers, 2004.

${ }^{36}$ ASME B36.19, Stainless steel pipe, American Society of Mechanical Engineers, 2004.

${ }^{37}$ Aflon, Tubos e conexões de PRFV (Plástico reforçado com fibra de vidro), Catálogo técnico, 1998.

${ }^{38}$ Aflon, Tubos e conexões de PEAD (Polietileno de Alta Densidade), PP (Polipropileno), PVDF (Fluoreto de Polivinilideno), Catálogo técnico, 1998.

${ }^{39}$ Telles, P.C.S., Tubulações industriais, sétima edição 1987.

${ }^{40}$ Marques, P.V., Tecnologia de soldagem ESAB, ESAB BR, 1991.

${ }^{41}$ Fortes, C., Eletrodos revestidos OK, ESAB BR, 2005.

${ }^{42}$ Fortes, C., Eletrodos inoxidáveis OK, ESAB BR, 2005.

${ }^{43}$ Davis, J.R., Metals Handbook, segunda edição 2003.

${ }^{44}$ Leffler, B., Stainless - Stainless steels and their properties, 2008.

${ }^{45}$ ASTM A 370, Standard test methods and definitions for mechanical testing of steel products, American Society for Testing and Materials, 2014.

${ }^{46}$ ASTM A 673/A673M, Standard specifications for sampling procedure for impact testing of structural steel, American Society for Testing and Materials, 2007.

${ }^{47}$ ASTM A 790/A790M, Standard specification for seamless and welded Ferritic/Aaustenitic stainless steel pipe, American Society for Testing and Materials, 2014. 
${ }^{48}$ ASTM A 923, Standard test methods for detecting detrimental intermetallic phase in duplex Austenitic/Ferritic stainless steels, American Society for Testing and Materials, 2014.

${ }^{49}$ ASTM E 23, Standard test methods for notched bar impact testing of metallic materials, American Society for Testing and Materials, 2012.

${ }^{50}$ ASTM E 112, Standard test methods for determining average grain size, American Society for Testing and Materials, 2013.

${ }^{51}$ ASTM E 562, Standard test methods for determining volume fraction by systematic manual point count, American Society for Testing and Materials, 2011.

${ }^{52}$ EN ISO 148-1, Metalic materials - Charpy pendulum impact test - Part 1, European standard, 2010.

${ }^{53}$ EN ISO 148-2, Metalic materials - Charpy pendulum impact test - Part 2, European standard, 2008.

${ }^{54}$ EN ISO 148-3, Metalic materials - Charpy pendulum impact test - Part 3, European standard, 2008.

${ }^{55} \mathrm{EN}$ ISO 15614-1, Specification and qualification of welding procedures for metallic materials - Part 1, European standard, 2012.

${ }^{56}$ ISO/TR 17671-3, Welding - Recommendations for welding o metallic materials Part 3, 2002.

${ }^{57}$ Portal ASME, disponível em: <http://www.asme.org/about-asme/history> Acesso em 08 de dezembro de 2014.

${ }^{58}$ Portal ASTM, disponível em: <http://www.astm.org/ABOUT/history_book.html> Acesso em 08 de dezembro de 2014. 
${ }^{59}$ Portal AWS, disponível em: <http://www.aws.org/about> Acesso em 08 de dezembro de 2014.

${ }^{60}$ Portal NACE, disponível em: <http://www.nace.org /About-NACE/ > Acesso em 08 de dezembro de 2014.

${ }^{61}$ Portal ANSI, disponível em: <http://www.ansi.org//about_ansi/introduction/history. aspx?menuid=1 > Acesso em 08 de dezembro de 2014.

${ }^{62}$ Portal API, disponível em: <http://www.americanpetroleuminstitute.com/ globalitems/globalheaderpages/about-api/api-history > Acesso em 08 de dezembro de 2014.

${ }^{63}$ Portal NORSOK, disponível em: <http://www.standard.no/en/toppvalg/aboutus/standards-norway/ > Acesso em 08 de dezembro de 2014.

${ }^{64}$ Portal Metrode Consumíveis para Soldagem, disponível em: <http://www.metrode.com/en-gb/documents/technical/document/DuplexTP2.html/> Acesso em 15 de abril de 2014.

${ }^{65}$ Costa Neto, P.L.O., Estatística, primeira edição 1977.

${ }^{66}$ Bastos, A.C., Dias, S.A.S., Diamantino, T.C., Ferreira, M.Y.S., Uma introdução à técnica do SVET, Corrosão e Proteção de Materiais, v.32, n.3, p. 235-249, 2013.

${ }^{67}$ Brandi, S. D.; Silveira, L. M. Y.; Vasconcellos, D. L. B., Aplicação da norma ASTM A923 - Prática A para identificação de fases intermetálicas em junta soldada de aço inoxidável superduplex UNS S32750, Revista Escola de Minas, v.63, n.1, p. 153 158, 2010.

${ }^{68} \mathrm{Brandi}$, S. D., Some aspects of weldability and jointability of duplex stainless steels, Materials Science Forum, v.426 - 432, p. 4063 - 4068, 2003. 
${ }^{69}$ Escriba, D. M.; Materna-Morris, E.; Padilha, A. F., Chi-phase precipitation in a duplex stainless steel, Materials Characterization, v. 60 n.11, p. 1214 -1219, 2009.

${ }^{70}$ Jianchun, L.; Tiyan, W.; Riquier, Y., Sigma-phase precipitation and its effect on mechanical properties of a superduplex stainless steel, Meterials Science and Engineering, v. 28, n. 1, p. $149-156,1994$.

${ }^{71}$ Tavares, S. S. M.; Pardal, J. M.; Lima, L. D.; Bastos, I. N.; Nascimento, A. M.; Souza, J. A., Characterization of microstructure, chemical composition, corrosion resistance and toughness of a multipass weld joint of superduplex stainless steel UNS S32750, Materials Characterization, v. 58, p. 610 - 616, 2007.

${ }^{72}$ Varol, I.; Lippold, J. C.; Baeslack III, W. A.; Bastos, I. N., Welding of duplex stainless steel, Key Engineering Materials. v. 69 - 70, p. 217 -252, 1992.

${ }^{73}$ Messer, B.; Opera, V.; Wright, A., Duplex stainless steel welding: Best practices, Stainless Steel World, n.12, p. $53-63,2007$.

${ }^{74} \mathrm{Esih}, \mathrm{I}$., Influence of thermal oxides on pitting corrosion of stainless steel in chloride solutions, Corrosion engineering, science and technology, v. 10, n.2, p. $64-69$, 2007.

${ }^{75}$ Silva, P. S. P.; Cetlin, P. R., Análise de fraturas, primeira edição, 1988.

${ }^{76}$ Análise de variância, disponível em: <http://www.portalaction.com.br/analise-deregressao/15-analise-de-variancia/> Acesso em 29 de abril de 2016.

${ }^{77}$ Análise estatística, disponível em: <http://www.portalaction.com.br/anova/13analise-estatistica/> Acesso em 29 de abril de 2016.

${ }^{78}$ Tabela de valores críticos de Cochran, disponível em: <http://www.watpon.com/table/cochran.pdf/> Acesso em 29 de abril de 2016. 